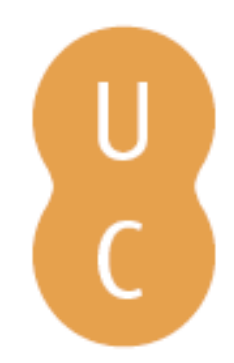

\title{
pommalina
}

\section{Plotino, escultor de mitos}
Autor(es): $\quad$ Oliveira, Loraine
Publicado por: Imprensa da Universidade de Coimbra; Annablume editora
URL
persistente: URI:http://hdl.handle.net/10316.2/31808
DOI: $\quad$ DOI:http://dx.doi.org/10.14195/978-989-26-0756-6

Accessed : $\quad$ 26-Apr-2023 11:37:10

A navegação consulta e descarregamento dos títulos inseridos nas Bibliotecas Digitais UC Digitalis, UC Pombalina e UC Impactum, pressupõem a aceitação plena e sem reservas dos Termos e Condições de Uso destas Bibliotecas Digitais, disponíveis em https://digitalis.uc.pt/pt-pt/termos.

Conforme exposto nos referidos Termos e Condições de Uso, o descarregamento de títulos de acesso restrito requer uma licença válida de autorização devendo o utilizador aceder ao(s) documento(s) a partir de um endereço de IP da instituição detentora da supramencionada licença.

Ao utilizador é apenas permitido o descarregamento para uso pessoal, pelo que o emprego do(s) título(s) descarregado(s) para outro fim, designadamente comercial, carece de autorização do respetivo autor ou editor da obra.

Na medida em que todas as obras da UC Digitalis se encontram protegidas pelo Código do Direito de Autor e Direitos Conexos e demais legislação aplicável, toda a cópia, parcial ou total, deste documento, nos casos em que é legalmente admitida, deverá conter ou fazer-se acompanhar por este aviso.

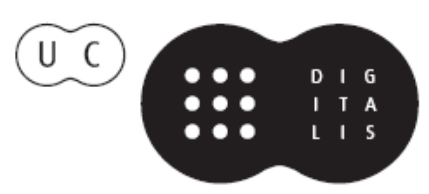




\section{Plotino, \\ escultor de mitos}

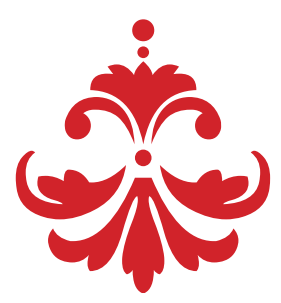

LORAINE OLIVEIRA

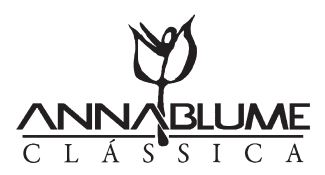


(Página deixada propositadamente em branco) 


$$
\begin{aligned}
& \text { Plotino, } \\
& \text { escultor de mitos }
\end{aligned}
$$




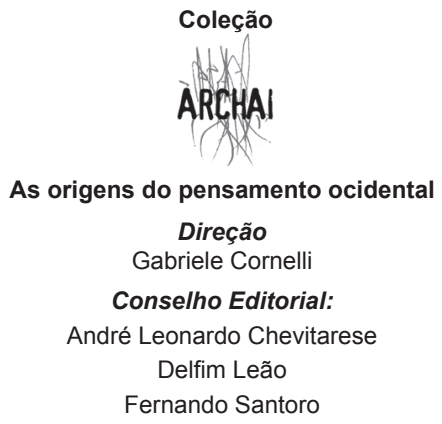

A coleção Archai é espelho do trabalho do grupo Archai: as origens do pensamento ocidental, agora promovido a Cátedra UNESCO Archai. Há mais de dez anos, desde 2001, o grupo Archai - desde 2011 Cátedra UNESCO Archai - promove investigaçôes, organiza seminários e publicaçôes (entre eles a revista Archai) com o intuito de estabelecer uma metodologia de trabalho e de constituir um espaço interdisciplinar de reflexão filosófica sobre as origens do pensamento ocidental. A presente coleção - parte do selo editorial Annablume Clássica - quer contribuir para a divulgação no Brasil de produçōes editoriais que busquem compreender, a partir de uma perspectiva cultural mais ampla, nossas origens. Nesse sentido, visando uma apreensão rigorosa do processo de formação da filosofia, e, de modo mais amplo, do pensamento ocidental, as obras que aqui são apresentadas procuram confrontar uma tradição excessivamente presentista de contar a história do processo de formação da cultura ocidental. Notadamente daquela que pensa a filosofia como um saber "estanque", independente das condiçōes de possibilidade históricas que permitiram a aparição desse tipo de discurso. Enraizando o "nascimento da filosofia" na cultura antiga, contrapondo-se às liçōes de uma historiografia filosófica racionalista que, anacronicamente, projeta sobre o contexto grego valores e procedimentos de uma razão instrumental estranha às múltiplas formas do logos antigo, a coleção Archai pretende contribuir para o lançamento de um olhar novo sobre os primórdios do pensamento ocidental, em busca de novos caminhos hermenêuticos de nossas identidades intelectuais, éticas, artísticas e culturais.

Conheça os títulos desta coleção no final do livro.

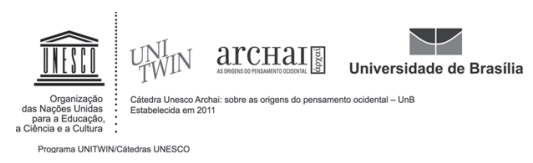




\section{Plotino, \\ escultor de mitos}

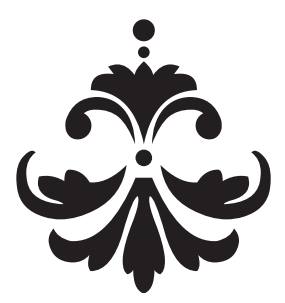

Loraine Oliveira
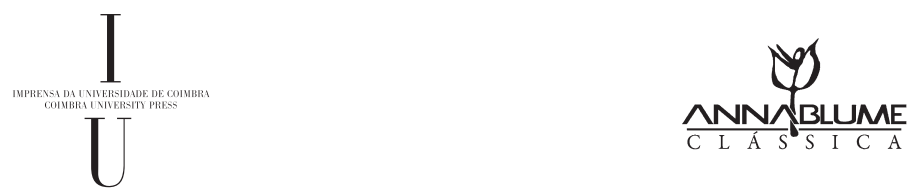


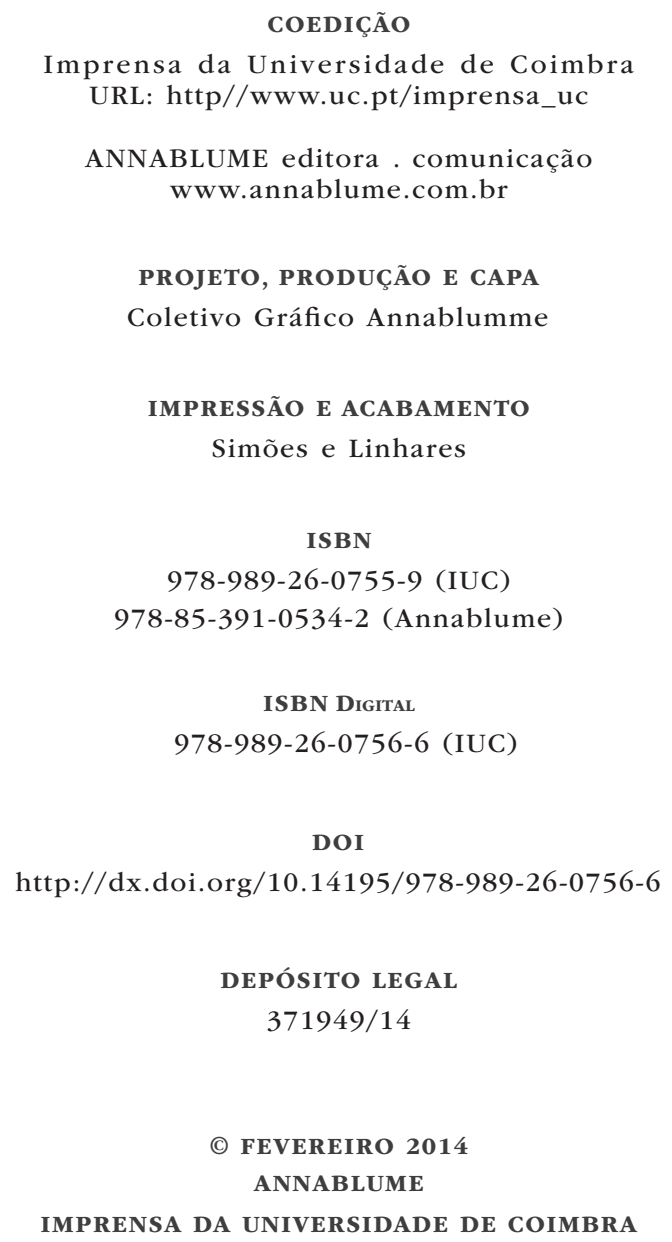


Para Iára, minha mãe 
(Página deixada propositadamente em branco) 
Não deixa de burilar a escultura de ti mesmo.

(Plotino, I 6 [1] 9, 13) 
(Página deixada propositadamente em branco) 


\section{AGRADECIMENTOS}

$\mathrm{C}$ ste livro é resultado da minha tese de Doutorado Discursos Miticos e Figuras Míticas: O uso dos mitos em Plotino, defendida na Universidade Federal de Minas Gerais, em dezembro de 2008, sob a orientação do Prof. Dr. Fernando Rey Puente. A ele agradeço imensamente pelos anos de trabalho exigente, cuidadoso, paciente e respeitoso. Também sou grata à sua amizade e aos diálogos em torno da possibilidade de publicar a tese em livro.

Consigno meus agradecimentos aos professores e pesquisadores que contribuíram para a realização desta pesquisa, dos quais gostaria de mencionar os membros da banca final Jacyntho Lins Brandão, Marcelo Pimenta Marques, Mauricio Pagotto Marsola, leitores criteriosos, e, em especial, Reinholdo Aloysio Ullmann (in memoriam), cuja amizade e presença marcaram-me profundamente. A Luc Brisson, pela interlocução, disponibilidade e acolhida para o estágio de pesquisa rea- 
lizado no CNRS, UPR 76, em Paris, assim como à sua diretora na época, Marie-Odile Goulet-Cazé. Expresso ainda minha gratidão a Michael Chase, Miriam Campolina Diniz Peixoto, Phillipe Hoffmann, Lambros Couloubaritsis e Joachim Lacrosse.

Fundamental para esta pesquisa foi o Séjour de Recherche na Fundação Hardt, em Vendoeuvres, Genebra, Suíça, onde pude encontrar um ambiente de trabalho produtivo, além de bibliografia rara e de difícil acesso. Registro ainda meu reconhecimento ao CNPq, que financiou a tese na forma de uma bolsa de doutorado nacional e de uma bolsa de doutorado-sanduíche.

Inúmeros amigos que foram importantes ao longo daquela odisseia merecem minha mais sincera gratidão, e sei que saberão se reconhecer nestas palavras. Todavia, não posso deixar de nomear expressamente Marilice Corona, Vera Rejane Dirong Böhlke, João Paulo Martins, Patrícia Lira, Emílio de Britto Negreiros e Flávio Ramos da Silveira. A Flávio Fontenelle Loque, por antes e agora. É preciso ainda agradecer especialmente à Elisa Franca e Ferreira, amiga dos anos mineiros, interlocutora e presença fundamental para que a tese assumisse a forma de livro. A ela coube criteriosa revisão. No labor em torno do livro, alguns novos diálogos pontuais também foram decisivos; por eles expresso meu reconhecimento a Beth Mori, a Claudio Reichert, a Ana Clara Cabeceira e Lennon Noleto.

Agradecimento especial merece ainda Gabriele Cornelli, professor de Filosofia Antiga na Universidade de Brasília, que desde minha chegada a ela, incentivou-me a publicar este livro e generosamente o acolheu na Coleção Archai, da qual é editor. 


\section{SUMÁRIO}

APRESENTAÇÃO

INTRODUÇÃO

NOTA PRELIMINAR

44

1. METÁFORAS, FIGURAS FILOSÓFICAS 47

1. DA PROCESSÃO E DA CONTEMPLAÇÃO 49

2. DO TEMPLO E DA ESCULTURA 59

2. TipOS DE DISCURSO 73

1. ORIGEM E LIMITES DA LINGUAGEM 75

2. A ANALOGIA 83

3. A PERSUASÃO 85

4. ARTIFÍCIOS DE REDAÇÃO E

PROCEDIMENTOS RETÓRICOS 89

3. DISCURSOS MÍTICOS 103

1. O MITO E O TEMPO 107

2. O LÓGOS DIANOÉTICO E OS DISCURSOS SENSÍVEIS 109

3. CONHECER O TEMPO 112

4. O MITO DO TEMPO 120

5. A DIALÉTICA 127

6. O TEMPO DO MITO 138 
4. DISCURSOS SOBRE AFRODITE E EROS 141

1. FACES DE Afrodite 146

2. DUPLA Afrodite 151

3. A PRIMEIRA AFrodITE 155

4. O PRIMEIRO EROS: DEUS 159

5. A SEGUNDA AFrOdITE 164

6. O SEGUNDO EROS: DAÍMŌN 167

7. O MITO DE POROS E PENÍA 175

8. O SIGNIFICADO FILOSÓFICO DAS

FIGURAS MÍTICAS 180

9. A RECOMPOSIÇÃO DO MITO 196

5. DISCURSOS SOBRE URANO, CRONOS E ZEUS 199

1. A GENEALOGIA EM V, 1 [10] 7, 30-35 209

2. A GENEALOGIA EM V, 8 [31], 12-13 215

6. FIGURAS MÍTICAS 227

1. O VOCABULÁRIO DO MITO 229

2. IMAGEM E IMAGINAÇÃO 230

3. O CARÁTER ENIGMÁTICO DO MITO 242

4. TERMOS DA FAMÍLIA DE AÎNOS EM PLOTINO 253

5. PLATÃO E OS ANTIGOS FALAM POR ENIGMAS 254

6. MÍSTICA: INTERPRETAÇÃO

ALEGÓRICA DE MITOS E MISTÉRIOS 266

7. FIGURAS DA ALMA 275

1. DIONISO DIANTE DO ESPELHO 277

2. DE DIONISO A PANDORA: A DESCIDA DAS ALMAS 287

3. O mito de Prometeu e Pandora 294

4. VERSÕES DO MITO DE PROMETEU

ANTES DE PLOTINO 302

5. UMA FIGURA ANÔNIMA 307 
8. ZEUS, FIGURA POLISSÊMICA

1. ZEUS: DEMIURGO E ALMA DO MUNDO

2. ZEUS, MINOS E DÍKE

3. O ZEUS DE FÍDIAS

4. DA ESCULTURA AO MITO:

A FACULDADE DA IMAGINAÇÃO

BIBLIOGRAFIA

1. FONTES PRIMÁRIAS

1.1. TEXTO GREGO DAS ENÉADAS

357

1.2. TRADUÇÕES COMPLETAS DAS ENÉADAS

357

1.3. TRADUÇÕES DE TRATADOS ISOLADOS E EDIÇŌES INCOMPLETAS

1.4. OUTROS AUTORES ANTIGOS

2. FONTES SECUNDÁRIAS

3. LÉXICOS E DICIONÁRIOS

APÊNDICE:

CATÁLOGO SIMPLIFICADO DOS MITOS DAS ENÉADAS 
(Página deixada propositadamente em branco) 


\title{
APRESENTAÇÃO
}

\begin{abstract}
A s pesquisas sobre Plotino no Brasil são, salvo raras Aexceçóes, bastante recentes tendo em vista que as primeiras teses defendidas em nosso país sobre o licopolitano começaram a surgir apenas a partir de meados do ano 2000. É precisamente no interior desse novo horizonte de pesquisa acadêmica sobre Plotino que devemos situar o livro Plotino, escultor de mitos de Loraine Oliveira, professora de Filosofia Antiga do Departamento de Filosofia da UnB, obra surgida originalmente como uma tese de doutorado defendida pela autora no ano de 2008 na UFMG.

O tema trabalhado pela pesquisadora - os mitos -, além de atual, tem o mérito imediato de não retomar certos temas no âmbito do pensamento plotiniano que, conquanto necessitem de investigações mais aprofundadas, têm despertado, talvez excessivamente, o interesse dos jovens estudiosos de Plotino, como, por exemplo, a "mística" plotiniana ou a sua henologia.
\end{abstract}


A investigação levada a cabo por Loraine Oliveira, é importante observar, está em consonância com pesquisas paralelas que estão sendo realizadas em outros países sobre esse tema e que tem sido publicadas como artigos ou capítulos de livros, mas Plotino, escultor de mitos tenta pela primeira vez - como a autora mesma assinala em sua conclusão - e aqui reside a originalidade de sua contribuição à pesquisa plotiniana hodierna, pensar de modo mais completo a problemática do mito no âmbito da filosofia de Plotino.

Antes, contudo, de nos voltarmos para a obra que aqui apresentamos ao leitor, é lícito, parece-nos, uma observação mais geral sobre o problema dos mitos em relação à filosofia antiga em geral e em relação à filosofia grega em especial, pois é no interior desse horizonte de pesquisa que devemos situar este livro.

Tornou-se um hábito no ensino superior da filosofia e mais ainda no ensino médio propagar a velha tese segundo a qual a civilização grega evoluiu do mito ao logos e essa transição coincidiria precisamente com o nascimento da filosofia. Ora, essa tese bastante divulgada em nosso meio, além de antropologicamente ultrapassada ${ }^{1}$, tem sido revista até mesmo por inúmeros estudiosos da área dos estudos clássicos ${ }^{2}$. O pressuposto mais inadequado inerente a essa ideia está em supor que um saber mítico e simbólico foi substituído por um saber racional e científico e essa ultrapassagem

1. Consultar especialmente os dois primeiros ensaios da obra ,já clássica, do antropólogo S. J. Tambiah (1990).

2. Ver o livro organizado por Buxton (1999), em especial o artigo de G.W.Most que oferece uma visão histórica dessa problemática. 
marcaria precisamente o advento do discurso filosófico e, consequentemente, o estabelecimento dos primórdios da racionalidade ocidental. Essa representação, já superada, está normalmente associada a outra ideia análoga, qual seja, a de dissociar o mundo grego de seu entorno histórico-cultural mais imediato atribuindo aos helenos uma origem quase autóctone, tal como se a civilização grega houvesse sido auto-produzida ${ }^{3}$. Em um curioso, e quase irônico paralelo com o mito grego relativo ao nascimento da deusa Atena a partir da cabeça de Zeus, tudo ocorreria como se a Grécia clássica houvesse se constituído a partir desse salto que levaria de um pensamento mítico e simbólico, típico das sociedades ditas orientais, para um pensamento racional e científico, característico do pensamento ocidental.

Há dois momentos importantes na construção dessa representação falaciosa do mundo grego, constructo este que devemos urgentemente rever em nosso ensino da filosofia e da civilização grega ${ }^{4}$. O primeiro, contido na expressão "milagre grego" criada por Ernest Renan em 1883, visava justamente assinalar o advento de uma civilização radicalmente inovadora a partir do século $\mathrm{V}$ a.C. na Grécia, e o segundo, mais marcante ainda para a manutenção dessa representação distorci-

3. Sobre a importância das culturas orientais na formação da Grécia ver, por exemplo, o livro de Walter Burkert (1999).

4. Um bom exemplo dessa revisão em um manual de filosofia é o livro recente de L. Couloubaritsis (2005), especialmente pp. 57-70 ("le facteur mythique") nas quais o autor critica a tese mito $\rightarrow \operatorname{logos}$ e onde ele apresenta sumariamente a sua reavaliação do mito no interior do pensamento grego. 
da, deu-se com o aparecimento do livro Vom Mythos zum Logos de W. Nestle no ano de 1940. Essa obra ou mais precisamente seu célebre título, dado que o livro certamente foi muito pouco lido, foi decisivo para a propagação da célebre equação mito logos em nossos dias 5 . Uma revisão bastante atual dos equívocos ínsitos a essa proposta, bem como do estágio atual dessa discussão pode ser lida em um sóbrio, bem documentado e erudito artigo de Robert Fowler (2011). O debate evidentemente é bastante complexo e envolveria também a discussão com outros célebres estudiosos, tais como B. Snell e J.-P. Vernant, partidários igualmente da equação mito $\rightarrow$ logos, ainda que alicerçada, no caso desses pesquisadores, em argumentos diversos daqueles apresentados por W. Nestle. Tudo isso, evidentemente, ultrapassaria completamente o escopo de uma apresentação e por essa razão deixaremos esses problemas de lado.

Voltemo-nos, pois, à obra que se segue a essas páginas de apresentação. O livro Plotino, escultor de mitos que se divide em oito capítulos, além da introdução, da conclusão, da bibliografia e de um breve catálogo enumerando alguns dos mitos encontrados nas Enéadas, propõe-se a investigar a presença, o uso e o significado dos mitos na obra de Plotino.

$\mathrm{Na}$ introdução, a autora esclarece a sua metodologia. Baseando-se em uma célebre passagem de Plo-

5. Para uma reavaliação crítica da obra de W. Nestle no interior de uma revisão histórica do problema mitos/logos consultar o artigo de G. W. Most, "From logos to mythos" na coletânea organizada por Buxton (1999). 
tino (III, 5 (50) 9, 24-29: "quem consegue inteligir o sentido dos mitos pode reunir o que foi separado na narrativa”), já analisada por outros especialistas, Loraine Oliveira procura examinar até que ponto o licopolitano é fiel em sua obra a essa ideia. Após a exposição do status quaestionis relativo ao seu tema, da qual se depreende as principais influências teóricas da autora na sua análise sobre os mitos (L. Brisson, L. Couloubaritsis e J. Lacrosse), ela estabelece uma diferenciação essencial para a compreensão de seu livro, a saber, aquela que existe entre discursos míticos e figuras míticas, distinção esta que estruturará os capítulos sucessivos de seu trabalho.

Após o breve primeiro capítulo no qual a autora enfatiza o caráter anagógico dos temas da processão e da contemplação em Plotino ao explorar duas metáforas por ele utilizadas para aludir a esses temas, a saber, as metáforas do templo e da visão, a jovem pesquisadora inicia o segundo capítulo de seu livro, o qual se propõe a analisar os discursos em geral.

O pensamento de Plotino, como qualquer leitor atento de sua obra se apercebe rapidamente, é uma longa e meticulosa discussão sobre os limites da linguagem, bem como sobre os meios de, apesar disso, continuar escrevendo na tentativa de circunscrever por meio da linguagem o Um, quer positiva quer negativamente. Ora, qualquer formulação positiva sobre o Um, como nos informa corretamente a autora, só pode ser entendida como uma analogia ou como uma metáfora, dado que, em si mesmo, o Um está situado em sua inefabilidade além da linguagem e, consequen- 
temente, além do pensamento discursivo. Mais ainda: ele se situa até mesmo para além do pensamento intuitivo. Como, pois, abordá-lo?

As analogias e as metáforas, portanto, devem servir de degraus para a ascensão da alma em direção ao Um, mas elas não são mitos em seu sentido mais próprio, isso porque, segundo Loraine Oliveira, elas não fazem uso do tempo para (re)conduzir a alma ao inteligível. A autora introduz aqui no terceiro capítulo um assunto especialmente caro a ela em sua análise dos mitos em Plotino, a saber, o tema do tempo. Dada essa especificidade temporal do mito, é preciso diferenciá-lo também da dialética que é para Plotino um procedimento não discursivo e, por conseguinte, não temporal. Isso a autora o faz com acuidade como se pode ler em uma passagem de seu terceiro capítulo: "a dialética é algo muito mais amplo que o mito, pois, mais que uma prática discursiva, ela constitui um caminho ascensional e uma conduta de purificação pelas virtudes. O mito, embora seja uma prática discursiva capaz de abrir a via para a eternidade, não é em nenhum momento descrito como caminho, nem como uma conduta, e nem mesmo como uma técnica. $\mathrm{O}$ mito também não é, em si, um método. Mas os mitos genealógicos recorrem aos procedimentos dialéticos de divisão e síntese. Nisso apenas o mito tange a dialética, sem, portanto, se identificar a ela”.

Um dos problemas, dos mais complexos e atuais, analisado pela autora nesse seu terceiro capítulo é o de saber em quê então o discurso mítico se diferenciaria dos discursos em geral. Ambos são discursos 
diacrônicos e todos os discursos são evidentemente narraçōes. Em outros termos, diferentemente de uma imagem que apresenta vários estímulos visuais captados simultaneamente por nossos olhos, quando queremos narrar algo acerca dessa imagem visual que contemplamos teremos necessariamente de elaborar uma narrativa - que se desenvolve sucessivamente - desses vários elementos que visualmente apreendemos em sua simultaneidade. Mas, se isso é assim, o que haveria então de diferente ou de específico no discurso mítico? A resposta para isso a autora encontra principalmente nos estudos de L. Brisson, por um lado, e nas análises de L. Couloubaritsis e J. Lacrosse, por outro.

O específico do mito no âmbito filosófico residiria então no fato de que ele apresentaria para a alma, por meio de um discurso genealógico (cosmogônico, teogônico ou antropogônico), realidades que, na verdade, se encontram hierarquizadas umas em relação às outras por possuírem graus distintos de poder. Cabe ressaltar ainda que esses nascimentos, apresentados no discurso mítico, não significam que os filósofos que porventura recorram a essa estratégia discursiva, tal como Plotino o faz, suponham que as realidades que são por eles assim narradas tenham efetivamente sido produzidas, antes esse modo de apresentação constitui na verdade um modo discursivo tipicamente humano de apresentar genealogicamente (isto é: por meio de relações de parentesco diacrônicas) realidades que em si mesmas são eternas, isto é, que são desprovidas de qualquer tipo de geração.

Por causa da importância fundamental do conceito de tempo para a determinação dos discursos míticos, 
a autora, introduz, ainda nesse fundamental terceiro capítulo de seu livro, uma breve análise do tratado III, 7 (5) de Plotino sobre o tempo e a eternidade a fim de melhor entender como o tempo e a alma seriam co-partícipes na produção do discurso mítico. Assim, se o tempo é produzido pela Alma e o tempo (entendido como genealogia) é uma especificidade do discurso mítico, então a alma possuiria uma relação estreita com o discurso mítico, relação esta que faz a autora afirmar que "só os mitos fazem uso da temporalidade para conduzir a alma ao inteligível”.

O passo seguinte de Loraine Oliveira é o de questionar qual tipo de imagem a Alma poderia ser. Ela diferencia dois tipos de imagem: a icônica e a mimética. No primeiro caso, a imagem seria mero produto ou projeção do modelo, no segundo, ela teria um papel ativo e não somente passivo, pois ela imitaria o seu modelo. A Alma seria para a autora, por conseguinte, tanto uma imagem icônica de seu modelo, o Intelecto, ao ser o seu produto, quanto uma imagem mimética do mesmo, ao ser "a atividade por meio da qual a Alma se move gerando o mundo sensível”. Por isso, ao dizer que o tempo é imagem da eternidade, Plotino estaria afirmando também que o pensamento intuitivo (nôेs), que é atemporal, seria o modelo do pensamento discursivo (diánoia), que é eminentemente temporal. Os mitos então, no dizer da autora, seriam não o caminho, mas sim apenas uma parte do caminho, parte esta que teria uma função anagógica no processo de condução, ou melhor, de recondução da alma ao Intelecto e deste ao Um. 
Nos capítulos quatro e cinco de seu livro Loraine Oliveira abandona o plano mais teórico que manteve no terceiro ao procurar mostrar nos textos mesmos de Plotino o uso que ele faz de dois discursos míticos, ou seja, de duas genealogias míticas. Assim, no quarto capítulo, a autora investiga a genealogia de Afrodite e Eros e, no quinto, a genealogia de Urano, Cronos e Zeus. Essas mais de sessenta páginas mostram minuciosamente em que medida Plotino tece e retece, ou na metáfora da autora, cara ao próprio licopolitano, esculpe e cinzela mitos tradicionais de um modo muito peculiar. Vale a pena o leitor se aprofundar atentamente nesses capítulos a fim de melhor entender como o discurso mítico de tipo genealógico opera efetivamente no interior da obra plotiniana.

Em seu sexto capítulo, a autora focaliza, por fim, o tema das figuras míticas. Em outras palavras, ela deixa aqui o plano do discurso mítico e, consequentemente, o do tempo, para deter-se na análise de algumas figuras míticas, isto é, a ênfase da pesquisa recai nesse capítulo na dimensão imagética dessas figuras míticas e não em sua relação com o tempo. Após algumas definições mais teóricas contidas nesse capítulo, os dois seguintes servem para a autora ilustrar essas ideias. Assim, o capítulo sétimo analisa as figuras da alma presentes na obra de Plotino, tais como as de Dioniso, Prometeu e Pandora e o capítulo oitavo, o último da obra, detémse, por fim, na investigação da figura mítica de Zeus que é usada pelo licopolitano de modo polissêmico em diversos contextos ao longo de seus tratados. Novamente aqui remetemos o leitor para essas páginas 
que merecem uma leitura atenta a fim de que se possa melhor compreender como efetivamente Plotino faz uso dessas imagens míticas em seus tratados.

O livro se encerra então com um catálogo simplificado organizado pela autora de alguns mitos presentes ao longo das Enéadas. É desnecessário pontuar a sua utilidade para o leitor dessa importante, complexa e fecundíssima obra filosófica, pois por meio dele poderemos começar a nos guiar melhor ao sermos conduzidos por um fio de Ariadne com o intuito de não nos perdermos nesse labirinto de mitos, imagens e metáforas que compóem o belo e variegado tecido do texto plotiniano. Só podemos augurar então que a jovem pesquisadora possa concluir no decorrer dos próximos anos um catálogo completo e exaustivo de todos os mitos e figuras míticas contidos nas Enéadas.

Não podemos finalizar a apresentação do livro Plotino, escultor de mitos sem, contudo, levantar algumas questôes mais gerais suscitadas pela leitura do mesmo. A primeira delas é a de saber como entender exatamente o uso alegórico dos mitos que Plotino faz. A autora sugere, na conclusão, a provável influência de Plutarco e mostra um paralelismo entre a necessidade de interpretar o mito em Plotino o qual, em sua formulação, "ao ser uma imagem, se exprime por enigmas e metáforas, que é preciso interpretar” com a necessidade que o licopolitano tem de interpretar as ideias de Pitágoras e de Platão. Obviamente, trata-se de exegeses diversas e restaria ainda saber como Plotino interpretaria os mitos de Platão, mitos esses que a autora, desde o início de sua pesquisa nos adverte que 
deixará de lado. Claro que sobre esse assunto já dispomos de uma bibliografia significativa, mas a questão metodológica que gostaríamos de ver mais detalhadamente discutida é a de saber como entender as diferenças de apropriação, caso elas existam, que Plotino faz ao assimilar mitos oriundos da tradição e mitos criados ou recriados por Platão.

Outra questão que a leitura do texto nos suscita é de saber se uma leitura alegórica do uso dos mitos seria a única ou a melhor chave de leitura para analisar o uso que os filósofos antigos fizeram dos mitos. Julgamos que a abordagem inaugurada pela reflexão do Schelling tardio, aquela apresentada em suas Preleçôes sobre a Filosofia da Mitologia, a saber, a de tratar os mitos não alegoricamente, mas sim tautegoricamente continua pouco explorada e, parece-nos, mereceria uma investigação mais apurada por parte dos estudiosos de filosofia antiga.

Um derradeiro aspecto presente nessa obra e que nos incita a pensar é a ênfase que a autora dá à relação existente entre tempo e mito. Se todo discurso é diacrônico, mas somente o mítico se caracterizaria por expor genealogicamente na narrativa o que se apresenta hierarquicamente na realidade, como caracterizar a dialética? Expliquemo-nos: se o tempo está diretamente vinculado à Alma, pois está o produziu, então a eternidade é característica do Intelecto e nessa medida deveria estar presente na dialética. De que modo isso pode ser pensado? Como entender melhor o papel que a dialética tem em Plotino? Como diferenciá-la da dialética platônica? Como diferenciar o pensamento 
discursivo (diánoia) do pensamento intuitivo (noûs) tendo em vista a relação tempo/eternidade?

O livro aqui apresentado tem, portanto, o grande mérito de analisar alguns problemas filosóficos essenciais - a linguagem, o mito, o tempo, a imagem -, problemas que nos fazem pensar e que deveriam servir como incentivo e encorajamento para uma leitura mais atenta e cuidadosa da obra de Plotino, esse grande filósofo da antiguidade tardia ainda pouco estudado em nosso meio.

Assim, Plotino, escultor de mitos surge no cenário editorial brasileiro como um dos primeiros frutos bem vindos oriundos da recente, mas já importante pesquisa de nossos jovens investigadores sobre esse pensador instigante e complexo, cuja obra, como se sabe, é decisiva não apenas para a compreensão da filosofia medieval, renascentista, e idealista, mas que continua fundamental até mesmo para o melhor entendimento da filosofia francesa contemporânea ${ }^{6}$.

Fernando Rey Puente

6. Menciono aqui apenas - deixando de lado a óbvia influência de Plotino sobre a filosofia da Idade Média e do Renascimento - os inúmeros trabalhos de Werner Beierwaltes que exploram a relação entre o neoplatonismo e o Idealismo Alemão e o livro em co-autoria de Jean-Marc Narbonne e Wayne Hankey (2004), onde se pode evidenciar a forte influência do neoplatonismo na constituição da filosofia francesa contemporânea. 


\section{BIBLIOGRAFIA}

BURKERT, W. (1999). Da Omero ai magi. Venezia: Marsilio Editore.

BUXTON, R. (1999). From Myth to Reason? Studies in the Development of Greek Thought, Oxford, UK: Oxford University Press.

COULOUBARITSIS, L. (2005). Aux origines de la philosophie européenne. De la pensée archä̈que au néoplatonisme. Bruxelles: De Boeck.

FOWLER, R. (2011). "Mythos and logos", Journal of Hellenic Studies, 131, pp.45-66.

NARBONNE, J.-M.; HANKEY, W. (2004). Lévinas et l'héritage grec \& Cent ans de néoplatonisme en France. Une brève histoire philosophique. Laval, Paris, Québec: Vrin.

TAMBIAH, S.J. (1990). Magic, Science, Religion and the Scope of Rationality, Cambridge, UK: Cambridge University Press. 
(Página deixada propositadamente em branco) 


\section{INTRODUÇÃO}

escultor toma um bloco de pedra. O cineasta, um bloco de tempo. Plotino, um bloco de mitos. Se a metáfora do escultor é reveladora da atividade filosófica nas Enéadas, para Tarkovski, em Esculpir o tempo, tornou-se reveladora da atividade do cineasta. E neste estudo, sutilmente revela o trabalho de Plotino, escultor de mitos.

O trabalho do escultor, que raspa, pule e limpa tudo o que é supérfluo na pedra representa, para Plotino, a purificação da alma pelas virtudes. E o escultor é aquele que contempla a forma antes de infundi-la na matéria. A visão da beleza na escultura abre caminho para a visão do belo em si, mas também simboliza a contemplação. Purificar-se e contemplar são atividades simultâneas. "Não deixa de burilar a escultura de ti mesmo", diz Plotino, instigando aquele que está em processo catártico a prosseguir. Esculpir, portanto, é tornar-se virtuoso. É contemplar. E é também retor- 
nar, transferindo a visão da forma para a pedra. Ao infundir a forma de uma Graça ou Musa em um bloco de mármore, o escultor transfigura, através da beleza da arte, a própria beleza inteligível.

Escultura, em grego antigo, é ágalma. Este termo também significa imagem, e aparece nas Enéadas com ambos os sentidos. Os mitos, para Plotino, são imagens, figuras. Eles pertencem ao campo da linguagem figurativa, uma das tentativas do filósofo de discorrer sobre aquilo que não cabe na linguagem proposicional. Plotino muitas vezes apenas aponta para as realidades inteligíveis com os mitos. Outras vezes, mostra e interpreta a imagem. E, terceiro caso do uso dos mitos, Plotino desenvolve um discurso, no qual os mitos são narrados segundo uma estrutura genealógica. Os conceitos de figuras e discursos não se excluem: um mesmo mito pode ser figura aqui, e entrar na estrutura discursiva ali. Por outro lado, uma figura mítica sempre está na ordem do discurso. E um discurso mítico compõe-se de figuras. A grande diferença, como será visto, é a relação com o tempo psíquico, através do tempo da narrativa, que não se tem no caso das figuras míticas. Isto é, no caso dos mitos que têm o valor de imagem, e que não constituem eles próprios discursos genealógicos. Pela proximidade com as imagens plásticas, a linguagem mítica das Enéadas é eventualmente comparada a pinturas. Mas a metáfora da pintura não é forte nos tratados; a da escultura sim. Ela aparece inúmeras vezes, e aqui é estudada em dois casos paradigmáticos: no início do texto, as esculturas do templo representam uma contemplação. Depois, o processo 
escultórico de Fídias representa a apreensão direta do inteligível, e a atividade de transferir a forma inteligível à pedra sensível.

$\mathrm{O}$ que seria, finalmente, o bloco de mitos? Em uma primeira interpretação, o bloco assemelha-se à pedra, um todo maciço; nela, cada mito das Enéadas parece ser o repositório de muitas versōes e interpretações do mesmo mito. Neste caso, o mito de Prometeu é paradigmático. Nesta primeira acepção, Plotino depura seus mitos de todo elemento estranho, de toda impureza e imperfeição. Ele raspa aqui e cinzela ali, até que o mito mostre uma forma inteligível. Mas nem todos são capazes de ver a forma; nem todos conseguem inteligir o sentido do mito. Porém, o bloco de mitos também pode significar o conjunto de figuras míticas que simbolizam o mesmo nível inteligível, e aqui o caso em análise são as figuras da Alma. Nesta segunda acepção, Plotino dispóe seus mitos como as esculturas do templo: elas conduzem, uma a uma, a contemplação. Não se trata de uma analogia com bloco em sentido próprio, uma grande massa de pedra, mas com bloco em sentido figurado. Ou seja, um conjunto de coisas consideradas como unidade.

As Enéadas são plenas de mitos. Da profusão dessas figuras enigmáticas, surge quase um convite a investigar em que consiste o uso dos mitos nos tratados. Ao iniciar tal pesquisa, deve-se levar em conta uma declaração de Plotino acerca da função dos mitos, se- 
gundo a qual eles dividem no tempo, segundo a ordem da genealogia, seres eternos, os quais se distinguem hierarquicamente. Quem consegue inteligir o sentido dos mitos pode reunir o que foi separado na narrativa (III, 5 [50] 9, 24-29). Um passo metodológico importante desta pesquisa consistiu, portanto, em tentar aplicar essa declaração de método a todos os mitos das Enéadas. Mas, ao elencar os mitos por um critério bem simples, os nomes dos deuses e dos heróis da mitologia, foi-se notando que grande quantidade de mitos não obedecem a esse esquema genealógico. Em outros termos, apenas os mitos do nascimento de Eros e Afrodite e os da tríade divina Urano, Cronos e Zeus são desenvolvidos de acordo com aquele enunciado. Todos os demais não o são. Portanto, em diversas passagens, percebe-se uma possível incongruência entre o que diz Plotino acerca do mito e o que ele faz efetivamente. Diante disso, e da inexistência de um estudo exaustivo sobre o mito em Plotino, a presente pesquisa se propôs investigar o uso do mito das Enéadas sob seus múltiplos aspectos.

De fato, atentando ao estado da questão, percebem-se quão escassos são os estudos acerca do mito em Plotino, no último século, ao menos. Há alguns artigos e capítulos de livros, em sua maioria francófonos. Dentre os primeiros estudiosos que parecem terse ocupado mais especificamente do assunto, Pépin e Buffière publicaram suas análises por meados dos anos 50. Jean Pépin, no artigo "Plotin et les mythes", datado de 1955, e depois retomado na forma de capítulo, no estudo Mythe et allégorie. Les origines grecques et les 
contestations judéo-chrétiennes, cuja primeira edição remonta a 1958, mapeia grande parte dos mitos das Enéadas e os analisa, alguns mais detalhadamente, como o nascimento de Eros e a tríade Urano, Cronos e Zeus, e outros mais rapidamente. Quanto à teoria do mito, Pépin considera a diacronia dos discursos míticos como sendo um instrumento de análise e de ensino. Parece, contudo, que um mérito de Pépin consiste em ter notado que o valor didático do mito é solidário a uma teoria da imagem, porquanto o mito constitui uma imagem que reflete a verdade. O trabalho de Pépin é fundamental para um estudo mais aprofundado sobre o mito em Plotino, pois ele coloca bases importantes para novos caminhos a seguir. Mas não se constituindo em uma análise exaustiva sobre a questão, ele não esgota o assunto. Buffière, seu contemporâneo, é também autor de uma obra importante, chamada Les Mythes d'Homère et la pensée grecque, que veio a lume no ano de 1956. Ele dedica-se à tradição das exegeses alegóricas de Homero. Nesse contexto, há um breve capítulo dedicado a Plotino, no qual ele explica que o licopolitano não foi hostil à exegese alegórica, que ele teria praticado ocasionalmente. Buffière mostra que Plotino se refere mais à Teogonia de Hesíodo do que a Homero propriamente. Ele analisa brevemente a tríade Urano, Cronos e Zeus, destacando a originalidade de Plotino em relação a Cornuto. Em outros capítulos, concernentes a certas figuras homéricas, como Odisseu ou Afrodite, por exemplo, Buffière menciona as interpretações de Plotino. A obra é, portanto, muito interessante, dado seu esforço em inserir Plotino 
nessa tradição exegética dos poemas épicos, notadamente os de Homero.

Em 1960, por ocasião da publicação do quinto volume dos Entretiens, da Fundação Hardt, Vicenzo Cilento, outro pioneiro, publicou seu artigo "Mito e poesia nelle Enneadi de Plotino". Destacando as fontes literárias das Enéadas, máxime as poéticas, o estudo de Cilento permite atestar que os mitos constituem um elemento importante para a composição dos tratados. Cilento segue investigando o estilo, a linguagem, a poesia, a lírica e a tragédia nos tratados, em um estudo ulterior, Saggi su Plotino.

Posteriormente, pode destacar-se o capítulo dedicado a Plotino em Introduction à la philosophie $d u$ mythe 1 - Sauver les mythes, publicado em 1996 por Luc Brisson, que, embora siga a conclusão geral de Pépin acerca do valor didático do mito, enfatiza o fato de o mito ser um tipo de discurso no tempo, usado para falar sobre realidades que não estão no tempo. Nas suas análises dos mitos, um ponto que o distingue de Pépin, é que Brisson considera que certos mitos plotinianos, como o de Prometeu, não são interpretados através de Platão, enquanto Pépin afirma mais categoricamente que Plotino sempre lê os mitos por meio da filosofia de Platão. Outro comentário digno de nota é o capítulo sobre Plotino, do livro de Robert Lamberton, Homer the theologian. Neoplatonist allegorical reading and the growth of the epic tradition, de 1986. Ele considera que há raros ecos de Homero nos tratados, de modo que Plotino pouco contribuiu para a história das alegorias do poeta grego. Entretanto, 
Lamberton enfatiza um aspecto interessante da filosofia de Plotino: suas reflexōes acerca dos limites da linguagem. Delas decorre a noção de a linguagem ter uma função mediadora entre o sensível e o inteligível.

Também se encontram, na bibliografia sobre o mito, em Plotino, as análises pontuais de Pépin sobre os mitos de Héracles e de Dioniso, e as de Pierre Hadot sobre Narciso, a figura de Eros e a tríade divina Urano, Cronos e Zeus, que vieram a lume entre o final da década de 60 e a década de 80 do século XX, todas fundamentais para a compreensão de cada qual desses mitos. Mas também, e não de somenos importância, somam-se aos comentários já citados os vários trabalhos de Lambros Couloubaritsis sobre o mito, desenvolvidos a partir do final dos anos 80. É dele a aproximação entre o conceito de genealogia e a noção de que os mitos dividem no tempo seres ingerados. Portanto, Couloubaritsis abre uma outra via para a compreensão do mito em Plotino, na medida em que propõe uma solução para a questão da relação entre o tempo da narrativa mítica e sua posterior destemporalização pelo pensamento, que não havia sido muito analisada anteriormente. De fato, os estudos sobre o mito em Plotino limitam-se, de modo geral, a constatar e, muitas vezes, a parafrasear a passagem acerca da função dos mitos, no tratado III, 5 [50], sem se deterem em analisar mais profundamente tal passo. A exceção é Pépin, na sua tentativa de dar um significado ao ponto em epígrafe, entendendo que tal procedimento tem uma função didática. Essa posição tem sido comodamente seguida por grande parte daqueles estudiosos de Plotino, que, ocupados com outros 
temas das Enéadas, deparam-se com algum discurso mítico, ou alguma figura, mas não se detêm na questão do mito, dados os limites dos seus trabalhos. Próximo disso parece ser o caso de Zamora, que, embora cite Couloubasitsis e Lacrosse, e, portanto, conheça a questão da genealogia, cinge-se a utilizar alguns dos mais conhecidos mitos das Enéadas para ilustrar os capítulos da sua tese, La génesis de lo múltiple. Materia y mundo sensible en Plotino, fazendo com que os mitos cumpram seu valor didático. Ideia interessante, mas que pouco acrescenta a um estudo acerca dos mitos no licopolitano.

Joachim Lacrosse, por sua vez, parece ter dado realmente um passo além dos seus mais ilustres predecessores. Conquanto ele mencione a questão dos mitos, em seus dois livros, é somente em um artigo publicado em 2003, “Temps et mythe chez Plotin”, que ele estabelece uma relação entre o tempo do mito, isto é, a genealogia, e o mito do nascimento do tempo, no tratado III, 7 [45]. A partir dessa relação, ele conclui haver uma complementaridade entre o mito e o tempo: o mito é testemunho de uma solidariedade do discurso e da vida psíquica, que é o tempo. Ambos, mito e tempo, inscrevem-se no núcleo do processo de desenvolvimento do tempo, por meio da multiplicação da Alma em uma profusão de almas singulares, cada qual com sua vida própria. Portanto, Lacrosse nota que o mito genealógico constitui um modo propriamente humano da relação entre a alma e a temporalidade; ele é de fato um ato da alma humana em busca da sua eternidade. Contemporâneo de Lacrosse, e também inspirado pelos estudos de 
Couloubaritsis, Bernard Collette, em seu livro Dialectique et hénologie chez Plotin, tenta estabelecer uma relação entre o mito e a dialética. Finalmente, no ano de 2006, Luc Brisson publica um artigo no qual ele enfatiza algo que já vinha esboçando em estudos anteriores: o termo mística em Plotino refere-se a um certo tipo de interpretação de mitos. Este artigo é interessante, pois, a partir dele, pode-se pensar a relação entre Plotino e as alegorias mistéricas de mitos, que aparecem em um autor como Plutarco; e também porque sugere que a exegese de mitos em Plotino tenha alguma relação com os modos de interpretação praticados nos mistérios, os quais, por sua vez, tinham que explicar o significado de certas imagens plásticas. Estas, enfim, parecem ser as contribuições mais recentes ao estudo dos mitos em Plotino. Não obstante, elas não se detêm de fato na relação entre imagem e mito. No entanto, podem-se encontrar diversas contribuiçôes a esse problema, na obra de Jean-Jacques Wunenburger, da qual se pode destacar Philosophie des Images. Ele fornece elementos interessantes para pensar a relação entre mito e imagem na Antiguidade, especialmente em Platão e no platonismo. Finalmente, cabe observar que, em língua portuguesa, até onde foi possível mapear a bibliografia, encontrou-se apenas um artigo acerca do mito em Plotino, que constitui um capítulo de Plotino - um estudo das Enéadas, publicado no ano de 2002, por Reinholdo Ullmann. Neste artigo, Ullmann afirma que o mito exprime em palavras concretas certos raciocínios abstratos, como se o mito pintasse tais 
raciocínios. Mas ele não desenvolve a relação entre imagem plástica e mito, sugerida na comparação. Para atenuar a imagem, e para indicar o sentido, ele entende que Plotino se sirva de fórmulas restritivas do tipo "como se". Uma contribuição importante de Ullmann foi ter destacado que os conceitos de alusão, sugestão, indicação e alegoria, subsumidos nos termos gregos ainittomai e sémaínein, designam o significado dos mitos. Finalmente, ele divide os mitos plotinianos em três grupos: aqueles que provêm da mitologia olímpica, os órficos e os da palavra. Este último grupo concerne ao caráter indicativo da linguagem humana. Afora esses comentários mais específicos, encontram-se ainda consideraçóes interessantes em torno do mito em Werner Beierwaltes e Alessandro Trotta, no contexto do estudo sobre o tempo.

Diante desses estudos, tão interessantes quanto lacunares, é possível experimentar o sentimento de um náufrago que não consegue vislumbrar a terra firme. Afinal, como conciliar todas aquelas ideias, a relação entre o mito e o tempo, entre o mito e a imagem, entre a interpretação dos mitos e a dos mistérios, entre o mito e a insuficiência da linguagem humana, entre o mito e a alegoria, entre o mito e a dialética? Seriam mesmo válidas todas essas pistas? Ou acabariam se excluindo mutuamente? Qual deveria ser, enfim, o ponto de partida para tentar realizar um estudo tão exaustivo quanto possível acerca do mito em Plotino?

Tentando não perder de vista aquelas questões, esta pesquisa, então, iniciou tentando compreender a declaração de Plotino que enuncia a função dos mi- 
tos. Por esse caminho estudaram-se as relações entre o mito e o tempo e entre os procedimentos de divisão e análise no mito e na dialética. Em um segundo momento, com o auxílio do Lexicon Plotinianum, de Sleeman e Pollet, foram investigadas as ocorrências do termo mito. Mesmo sendo elas bastante escassas e não havendo cognatos, nos tratados, percebeu-se, já naquele momento, que havia outra possibilidade de abordagem do problema, pois, dentre as sete ocorrências, nenhuma outra, além daquela que enuncia a função, menciona o aspecto genealógico dos mitos. Mas recorrentemente as outras seis ocorrências continham a noção de subentendido (ainittomai) e também a de imagem.

Disso surgiu a verificação das ocorrências da palavra ainittomai e de seus cognatos. Essas palavras aparecem nas Enéadas para designar, tanto os mitos, como os discursos de Platão e de Pitágoras. Ora, sendo Plotino um exegeta de Platão, e sabendo-se que as Enéadas constituem um diálogo com a tradição filosófica e também com a mítica, a segunda possibilidade entrevista foi investigar a relação entre a exegese mítica e a desses antigos e bem-aventurados filósofos. Mas essa, se levada a fundo, seria uma outra pesquisa, motivo pelo qual o presente estudo restringiu-se às ocorrências dos termos da família de aînos Por outro lado, o termo ainittomai provém do vocabulário dos exegetas de Homero e Hesíodo. Partindo, portanto, do pressuposto de que a postura de Plotino, diante dos mitos, é alegórica, pois estes possuem um sentido oculto na letra do texto, tentou-se situar Plotino em relação à tradição exegética alegórica na filosofia. A grande dificuldade 
dessa tarefa consiste em que nem tudo o que foi chamado alegoria é efetivamente alegórico, e nem tudo o que é alegórico recebeu esse nome na Antiguidade. A alegoria, na Antiguidade, é de fato um campo inexaurível de estudos. Mas o que foi decisivo para eliminar o intuito de esboçar uma história da alegoria a qual pudesse situar Plotino em uma linhagem que sucede àquela dos defensores de Homero e resulta em uma tentativa de reconciliar Platão e Homero, já no médioplatonismo de um Numênio, por exemplo, lido, como se sabe, por Plotino? É que Plotino, embora pareça assumir uma postura alegórica, não é exatamente um alegorista de Homero e Hesíodo. Ele não menciona os nomes dos poetas, nem mesmo os títulos dos poemas, mas, mais importante que isso, ele não comenta linha a linha sequer uma passagem dos poemas, como faz Porfírio no Sobre a Gruta das Ninfas, ou como antes fizera Heráclito, o alegorista, defendendo Homero contra Platão, ou ainda Cornuto, exegeta de matiz estóica. Todavia, esses dois temas, a exegese e este tipo especial de exegese, que é a alegoria, permaneceram como um pano de fundo sobre o qual se desenhou a estrutura final do estudo e sobre o qual se articularam as análises dos mitos, não deixando de estar presentes, embora não tenham sido aprofundados.

Finalmente, cabe observar que, desde o início, elaborava-se uma espécie de inventário dos mitos. Em dado momento, essa tarefa se avultou e pareceu ser o melhor caminho para tentar compreender o uso do mito nos tratados. Mas essa seria também outra pesquisa. Por isso, nesse momento, decidiu-se não 
prosseguir o catálogo, do qual o início encontra-se em apêndice, ao final deste livro. Porém, a ideia de catalogar todos os mitos exigiu que fossem tomadas certas decisões que limitassem e, ao mesmo tempo, direcionassem os passos da pesquisa. Uma delas foi não inserir no catálogo mitos platônicos como, por exemplo, o do demiurgo, no Timeu. Foi dessa primeira cisão que surgiu o critério limitador, a saber, incluir apenas os nomes de deuses e heróis da poesia épica que se pudessem encontrar nas Enéadas. Todavia, dentre os mitos passíveis de catalogar, talvez aquele que tenha sido o mais importante, pois, sem dúvida, foi o que forneceu mais material para análise, é um mito que, de certa maneira, se poderia definir como platônico. Trata-se do mito de Eros e Afrodite, que têm por base passagens do Banquete. Mas como ele concerne a deuses da épica hesiódica e homérica, ajusta-se perfeitamente ao critério nomes de deuses e heróis. Entretanto, porque em Plotino as versões dos mitos muitas vezes não correspondem exatamente à épica, e também porque há mitos provenientes de outras fontes, como o orfismo, àquele critério acrescentou-se uma questão a investigar neste estudo: versóes anteriores dos mitos que pudessem ter servido de fontes para Plotino. Assim é que as análises de mitos empreendidas no presente estudo foram pontuadas pela preocupação de indicar algumas versões, remontando sempre ao passado mais distante, ou seja, a Homero e Hesíodo, e avançando por autores de matriz platônica anteriores a Plotino, sempre que possível. Também se tentou buscar referências a essas figuras míticas nos diálogos platônicos. Duas ex- 
ceções, com respeito a Homero e Hesíodo, localizadas até então, foram analisadas na pesquisa, com o escopo de preservar a variedade das fontes de Plotino. Trata-se do mito de Dioniso, cuja versão plotiniana parece ter origem órfica e, talvez, também passe por Plutarco, e uma figura não nomeada, a qual aqui é assim tratada, embora tenha sido associada a Narciso por Hadot e, em geral, pelos estudiosos de Plotino.

Durante a própria organização do catálogo, percebeu-se não ser necessário exaurir em análises todos os mitos até o momento coletados nos tratados, pois ficou patente que havia dois grandes grupos de mitos: os genealógicos e os não-genealógicos. Nesse segundo grupo também se constatou nem todos serem interpretados por Plotino, o que significa que alguns se confundem com metáforas. Disso decorre uma hipótese de trabalho: há um uso variado do mito em Plotino. Para compreendê-lo, seria necessário analisar pelo menos uma amostra de mitos que contemplasse tanto os genealógicos como os demais, e, dentre esses, tanto os interpretados como os não-interpretados. Do catálogo também surgiu a confirmação de uma hipótese conhecida entre os autores hodiernos, que se ocuparam do mito em Plotino: boa parte dos mitos concerne à Alma em seus diversos aspectos. Por isso a opção por selecionar, para as análises dos mitos não-genealógicos, alguns daqueles que remetessem à Alma. Finalmente, o que se catalogou foi o suficiente para comprovar também a polissemia das figuras míticas, sendo Zeus um caso paradigmático, pois ele pode representar o Um, o Intelecto ou a Alma, além 
de também ser mencionado com valor de metáfora. Assim, a escolha dos mitos incluiu todos os genealógicos e apenas alguns não-genealógicos, de acordo com os critérios descritos.

Porém, é importante notar: da diferença entre os mitos genealógicos e os que não são narrados segundo um esquema de parentesco surgem dois conceitos estruturais: discursos míticos e figuras míticas. A expressão discursos míticos refere-se à forma genealógica e, por consequência, ao mito como um tipo de discurso que reflete a estrutura temporal do pensamento discursivo da alma humana. A expressão figuras miticas refere-se ao mito como imagem, isto é, como algo que mostra, que indica, que alude a um referente situado para além das suas determinações sensíveis. Todavia, os dois conceitos se alargam, na medida em que, por um lado, se tenta compreender as estratégias discursivas dos tratados em geral, a origem e os limites da linguagem, a relação entre os discursos sensíveis e o seu referente, quando este não é da ordem do sensível. Por outro, percebe-se que o vocabulário da imagem é extenso nas Enéadas. Mais que isso, há uma ontologia da imagem na filosofia de Plotino, pois, excetuando o Um, que é o primeiro princípio, todos os demais níveis de realidade são imagens, cada qual do nível anterior. A partir da classificação figuras míticas e discursos míticos, surge outra hipótese, que é investigada ao longo de todo o trabalho: o mito é um tipo de imagem diacrônica, no que difere das imagens visuais, que apresentam tudo junto, mas como elas, ele também concerne à faculdade da imaginação e à do pensamento discur- 
sivo. Em suma, segundo tal hipótese, o mito situa-se em uma espécie de meio caminho entre as imagens visuais e os discursos em geral. Assim como a poesia é uma pintura falada, a pintura é uma poesia muda, teria dito Simônides, reconhecendo o poder figurativo da linguagem poética. O parafraseando, pode-se dizer que, em Plotino, assim como o mito é escultura fala$\mathrm{da}$, a escultura é mito silente.

\section{NOTA PRELIMINAR}

O sistema de numeração das Enéadas segue o seguinte critério: o primeiro número, em algarismo romano, indica a Enéada, consoante a edição de Porfírio, podendo variar de I a VI. O segundo número, arábico, indica a posição do tratado dentro da Enéada, variando de 1 a 9. O terceiro número, em caractere arábico, entre colchetes, designa a posição cronológica do tratado no corpus plotiniano. Os dois números seguintes, arábicos, separados por hífen, indicam as linhas em que a citação inicia e termina. Assim, por exemplo, V, 1 [10] 2, 1-5 deve ser entendido da seguinte forma: primeiro tratado da quinta Enéada, o décimo na ordem cronológica, capítulo dois, linhas um a cinco. Essa opção de numeração tem o objetivo de ser a mais completa possível, permitindo ao leitor situar o tratado, tanto em uma edição que siga a de Porfírio, como em uma que se guie pela ordem cronológica. Sempre que for referida alguma Enéada, será omitido o nome de Plotino e da obra na nota, sendo suficiente a notação numérica. 
Quanto às traduções, não havendo indicação do tradutor, são de minha inteira responsabilidade. $\mathrm{O}$ leitor vai observar que certos tratados de Plotino receberam ora tradução minha, ora de outrem. Isso se explica devido ao fato de que dois tradutores lusófonos - Bernardo Brandão, para o tratado VI, 9 [9], e Baracat Júnior, para as Enéadas I a III - defenderam e disponibilizaram seus trabalhos, depois que certo número de traduções de passagens desses tratados já haviam sido feitas por mim. Em reconhecimento ao valor de seu trabalho, optei por fazer uso dessas traduções, sempre que possível. A outra tradução lusófona utilizada é de Luciana Soares, do tratado V, 8 (31), publicada na revista Kriterion (107) 2003.

Os demais autores antigos seguem o seguinte critério: havendo uma tradução lusófona disponível, a cito. Não a havendo, traduzo. Como são numerosas, minhas traduções não estão indicadas, apenas as alheias. Entretanto, para não sobrecarregar nas notas dos poemas de Homero e de Hesíodo, sirvo-me das traduçóes lusófonas citadas na bibliografia.

Quanto às ediçôes gregas, para Plotino, foi utilizado o texto grego estabelecido por Henry-Schwyzer (ed. minor). Quanto às traduções de Plotino para outras línguas modernas, todas as de que me servi estão indicadas na bibliografia, sendo que para certos tratados foram preferentemente utilizadas traduções comentadas do tratado isolado, como é o caso do tratado III, 5 [50], que conta com duas edições indispensáveis ao seu estudo: a de Wolters e a de Hadot. 
Concernente aos autores antigos em geral, tanto os títulos das obras, como os nomes dos autores, são traduzidos para o português, mesmo se não há referência bibliográfica lusófona correspondente. Para tanto, o Indice de nomes próprios gregos e latinos, de Ureña Prieto, constitui uma ferramenta de grande utilidade. Por fim, quanto aos comentários hodiernos, optei por traduzir as citações, em todas as notas e no corpo do texto, pensando em facilitar o acesso do leitor. As citações dos antigos seguem as normas internacionais vigentes para cada caso; as da literatura secundária, o sistema autor-data, da forma mais simplificada possível.

Para a transliteração dos termos gregos, seguem-se os critérios estabelecidos pela SBEC (Sociedade Brasileira de Estudos Clássicos), disponíveis na revista Clássica, 2006, 19, 2. Não desejando mudar substancialmente o texto original da tese, a revisão técnica do livro consistiu basicamente em mudar todo o sistema de citações, em apagar as numerosas citações em grego das notas e em transliterar o grego do texto e das notas. Não é uma tarefa mecânica, especialmente em se tratando de um texto repleto de citaçóes e referências. Somente ao ver a primeira versão do livro, pude vislumbrar algo que estava oculto no texto original e encontrar o título atual. Obviamente isso implicou em um trabalho sutil e minucioso de limpeza, incisão e polimento, até chegar à forma que o leitor tem em mãos. 
1.

\section{METÁFORAS, FIGURAS FILOSÓFICAS}

presente capítulo tem por escopo apresentar as-
pectos da filosofia de Plotino, enfatizando seu
caráter anagógico, através, especialmente, de metá-
foras ligadas à visão. Cabe observar, brevemente, que
uma introdução por meio de metáforas parece uma
forma legítima de apresentar as Enéadas, porquanto os
tratados testemunham um "pensamento filosófico por
imagens", segundo uma expressão de Bréhier (1955,
293), referindo-se às metáforas. Naturalmente, é pre-
ciso reconhecer que não seria possível compreender
a filosofia plotiniana somente através das metáforas,
caso elas fossem subtraídas dos textos. Como o pró-
prio Bréhier (1995, passim) notou, se as metáforas são
isoladas, elas adquirem o tom de enigmas, e, diante
deles, sente-se o delicado prazer de um descobridor de
enigmas. Efetivamente, imagens desse tipo vêm por
acréscimo. As metáforas quebram o ritmo do discur-
so estruturado em conceitos abstratos, exigindo uma 
atenção e uma disponibilidade, e também certa tensão do leitor ou do ouvinte, entrando no circuito afetivo e imaginativo, e redirecionando, por este caminho, o pensamento. Mas uma imagem, uma figura, só mostra para quem está atento e disposto a ver. Todavia, não se deve obliterar que, mesmo tentando comunicar uma intuição filosófica dificilmente formulável em conceitos abstratos, a metáfora permanece sempre inexata. Da sua insuficiência nasce a sugestão para seguir além da própria metáfora, ultrapassando-a. Quando uma imagem é proposta para representar a realidade, tal representação nunca é exata. Mas justamente essa inexatidão, ao ser reconhecida, orienta em direção à realidade (BRÉHIER, 1955, 300). Então, as figuras filosóficas - não somente as metáforas, mas também os mitos - tentam dirigir a intuição a uma realidade inteligível presente inteira por tudo.

A escolha de metáforas ligadas à visão justifica-se, na medida em que a união da alma com o Intelecto e o Um é descrita, em grande parte dos casos, em termos de visão e de contemplação e também porque o tema da visão liga-se ao da imagem sensível e, por via de consequência, ao do caminho anagógico introduzido por ela. A descrição desse caminho semelha-se a certas iniciações religiosas, nas quais a visão também desempenha importante papel, o que fica claro na escolha da metáfora do templo. Finalmente, porque o mito situa-se entre as imagens visuais e os discursos, de tal modo que ele pode participar dos caminhos passíveis de conduzir a alma humana à unidade: a beleza, que se transfigura em amor, e a dialética. 
Por fim, é mister considerar que, de modo geral, Plotino parece aplicar com cuidado o uso de mitos e metáforas, introduzindo-os, não poucas vezes, por termos explicativos, cuja função é advertir o leitor de que aqueles termos não podem ser tomadas literalmente. Este é de fato o caso da metáfora do templo e das esculturas, a qual se encontra no tratado VI, 9 [9]. Efetivamente, essa metáfora representa a união da alma com o Intelecto e o Um. Porém, compreender tal união pressupõe a doutrina do Um, ou Bem, que é exposta de modo detalhado e aprofundado, cronologicamente pela primeira vez, nesse mesmo tratado, VI, 9 [9]. Essa doutrina não é posta em questão nos tratados posteriores, embora Plotino tenha se ocupado em analisar detalhadamente aspectos da união que, ou não foram abordados, ou que ficaram sem solução em VI, 9 [9].

\section{DA PROCESSÃO E DA CONTEMPLAÇÃO}

Na economia de VI, 9, [9] e das Enéadas, em geral, o mesmo termo, "um" (hén), designa, tanto a unidade interna das coisas, como o princípio absoluto. Para diferenciar uma coisa da outra, nas traduções para as línguas modernas, normalmente utiliza-se a inicial maiúscula, indicando o princípio absoluto, Um. Porém, Plotino mantém intencionalmente a polivalência, pois, como diz Brandão (2007, 106): "Ao se investigar a unidade das coisas, será possível chegar, de um certo modo imperfeito, já que baseado no discurso, ao Um”. Mas também 
porque Plotino estabelece que todas as coisas existem por participarem do Um, postulando o Um como a causa de todos os seres: "Todos os seres são seres pelo Um” (VI, 9 [9] 1, 1 - trad. Brandão). Plotino sempre o utiliza no nominativo neutro singular, tò hén, mesmo quando isso poderia representar uma fratura gramatical. Mas trata-se de uma decisão que não é meramente, é filosófica: o Um nunca é objeto, nem complemento. Se filosoficamente está além do Ser, gramaticalmente só pode ser sujeito, motivo pelo qual não se declina. Dele nada se predica. $\mathrm{O}$ Um não é mais de um, por isso não pode ser plural.

Ele faz uso de diferentes metáforas para ilustrar a participação das coisas na unidade. Primeiro, menciona um exército, um coro e um rebanho: coisas compostas de múltiplos elementos que permanecem distintos, mas que são ditos um exército, um coro ou um rebanho (VI, 9 [9] 1, 4-6). A seguir, coisas compostas de múltiplas partes que formam um conjunto único, como uma casa e um navio (VI, 9 [9] 1, 6-7). Esse procedimento, no qual Plotino recorre a diferentes metáforas, uma seguida da outra, é típico nas Enéadas. Ferwerda (1965, 194) denomina "verificação": ao trazer uma nova metáfora para elucidar a mesma dificuldade, sob um outro ângulo, verifica-se a primeira.

Seguindo o raciocínio, Plotino diz que, do mesmo modo, as grandezas contínuas (synekhê megéthè) existem em virtude do um (VI, 9 [9] 1, 8-17; ARISTÓTELES, Metafisica, I, 1, 1052 a 19-21). Nesse ponto, ele considera que a Alma dá unidade a todas as coisas, mas ela 
própria não é o Um ${ }^{1}$. Com efeito, em relação às coisas descontínuas, como, por exemplo, um coro, a Alma está mais perto do Um. Porém, sua unidade, ela também a tem por participação (méthexis - VI, 9 [9] 1, 1838). Em que sentido a Alma é considerada contínua? E por que é múltipla? Plotino conclui o primeiro capítulo, afirmando que a Alma não é composta de partes, por isso é contínua, e por isso é uma. Entrementes, é múltipla, "pois várias são suas potências: raciocinar, desejar, perceber, as quais pelo um, como que por uma atadura, são reunidas" (VI, 9 [9] 1, 40-42 - trad. Brandão). O capítulo conclui-se, situando, por assim dizer, a Alma entre as coisas posteriores a ela, às quais ela confere unidade, e o que lhe é anterior, que lhe dá unidade: "Certamente a Alma, sendo 'um' leva também ela o um a outra coisa. Mas o recebe também ela, de outro" (VI, 9 [9] 1, 42-43 - trad. Brandão). Nas Enéadas, com efeito, a Alma confere unidade às coisas sensíveis: o mundo, a natureza, o homem. Essas coisas são, pois, posteriores à Alma. Claro que a relação de posterioridade também deve ser compreendida em sentido metafórico. Como observou Pradeau (2003, 50), no conjunto dos tratados, a exterioridade e a sucessão cronológica permitem caracterizar bem a relação das três realidades (o Um, o

1. Alma (psychế) designa tanto a parte superior da Alma, também designada Alma-hipóstase, como a alma do mundo, ou ainda as almas individuais. Não raras vezes, Plotino joga com a polivalência. Aqui, por exemplo, pode-se subentender qualquer um dos sentidos, pois todas as almas conferem unidade às coisas sensíveis. Nas línguas modernas, é costume grafar com inicial maiúscula quando se trata da parte superior da Alma. 
Intelecto e a Alma), as quais Plotino quer mostrar que são diferentes uma da outra, e que provêm umas das outras. Desse modo, pode-se dizer que existe primeiro o Um, depois, o Intelecto, que vem do Um. Finalmente, a Alma, que vem do Intelecto. A anterioridade da causa é postulada por Plotino nos seguintes termos:
Resumindo: por um lado o Um é o primeiro e, por outro, o Intelecto e as formas e o ser não são primeiros. Com efeito, cada um de- les é uma forma constituída de muitas coisas, composta e posterior. Pois aquilo de onde cada coisa provém é anterior a cada coisa (VI, 9 [9] 2, 29-32 - trad. Brandão) $)^{2}$.

Ora, é consabido que, para Plotino, o ser e a unidade são indissociáveis; logo, a unidade constitui a realidade própria de cada coisa. O Intelecto possui em si mesmo o ser e todas as formas inteligíveis. Por isso, ele transmite ser e unidade às coisas, e é um ${ }^{3}$. Mas, igualmente, o Intelecto é múltiplo porque é ser (VI, 9 [9]

2. O termo Intelecto (nô̂s) também é grafado com inicial maiúscula, nas línguas modernas, para designar a segunda hipóstase. Note-se que em Plotino há também o Intelecto da Alma, correspondente à parte da Alma suspensa à segunda hipóstase. Essa parte é fundamental para que a alma humana atinja o conhecimento do Intelecto e, a partir desse, do Um. Quando se trata do intelecto da alma humana, ou da alma do mundo, será grafado sem maiúscula. Quanto ao Intelecto da Alma-hipóstase, fica a dúvida: será ele o próprio Intelecto participado pela Alma? Questão interessante que ainda faz correr tinta entre os especialistas e extrapola os limites deste estudo.

3. Esta tese remonta a Aristóteles, Metafísica, 1003 b 22 -27; 1054 a $13-17$. 
2, 22-24). Não obstante, Plotino ainda observa outro aspecto pelo qual o Intelecto também não pode ser o primeiro princípio: "Se ele próprio é o que intelige e o inteligido, será duplo e não simples, nem um” (VI, 9 [9] 2, 36-37 - trad. Brandão) ${ }^{4}$.

Bem, no tratado VI, 9 [9], conforme está dito pouco acima, Plotino não explica detalhes da chamada processão das hipóstases. Ele apenas caracteriza a Alma, em parte do primeiro capítulo, e o Intelecto, no segundo, como acaba de ser visto. Quanto ao Um, dos capítulos 3 a 6 , ele tenta caracterizá-lo, mostrando que o Um é princípio de todas as coisas (VI, 9 [9] 3, 1415). Ele está, portanto, além do Intelecto, das formas e de tudo o que é, razão pela qual nada se pode predicar dele (VI, 9 [9] 3, 33-45). Caso ele possuísse algum atributo, ele seria ao menos duplo. Eis porque nada lhe convém: nem a escrita, nem a fala, nem o conhecimento (VI, 9 [9] 4, 1-10)5. Com efeito, o conheci-

4. Nessa asserção reside, enfim, a crítica que Plotino tece a Aristóteles no tratado V, 1 [10] 9, 7-9, onde observa que, para o Estagirita, o primeiro é separado e inteligível, mas, por outro lado, o primeiro pensa a si próprio, logo, deixa de ser primeiro. A crítica à teoria do primeiro que pensa a si mesmo possivelmente referese à Metafísica $1071 \mathrm{~b}$.

5. Plotino, consciente das dificuldades da linguagem para expressar o Um, não nega a necessidade da mesma para indicar o caminho até ele. "Por isso <Platão $>$ diz que ele nem pode ser dito, nem escrito, mas dizemos e escrevemos para enviar até ele e, a partir das palavras, despertar para a contemplação, como que mostrando o caminho para alguém que queira contemplar algo. Pois o ensinamento vai até a estrada e a jornada, mas a contemplação dele já é trabalho de quem quer ver" (VI, 9 [9] 4, 11-14 - trad. Brandão). Plotino parece aludir à Carta VII, $341 \mathrm{c}$-e, e alude também ao tema do caminho no mito de Odisseu, em I, 6 [1] 8, 18. 
mento implica a multiplicidade; por conseguinte, para atingir o conhecimento do Um, é mister que a Alma ultrapasse o conhecimento intelectual e, finalmente, remonte a seu princípio, o Um (VI, 9 [9] 4, 16-35). Assim, a ascensão da Alma se dá em duas etapas: primeiro ela deve subir até o Intelecto. Isso porque a Alma procede dele. Eis o que diz Plotino, no tratado em estudo:
(...) ela <a Alma> existe a partir do Intelec- to e que, participando do lógos que procede deste, retém a virtude. Depois disso, deve admitir que existe um outro intelecto além do que raciocina e que é chamado de racio- nal. E que os raciocínios já estão como que em distensão e movimento, e que as ciências são discursos na alma, manifestadas, neste caso, porque o Intelecto vem a ser causa das ciências na alma (VI, 9 [9] 5, 5-12 - trad. Brandão, ligeiramente modificada).

Plotino, aqui, examina parte da estrutura inteligível. Em síntese, pode-se tentar compreender a passagem, a partir da noção de lógos. Como explica Brisson $(1999,87-108)^{6}$, Plotino retoma dos estóicos, não so-

6. Na medida em que se trata apenas de apontar alguns traços gerais da problemática do lógos em Plotino, seguem-se algumas consideraçôes avançadas por Brisson no referido artigo. Não obstante, há outros estudos que podem ser consultados: COULOUBARITSIS, 1992, 231-243. FATAL, 1998. TURLOT, 1985, $517-$ 528. Finalmente, o tema do lógos é retomado, sob diferentes ângulos, nesta tese, em I. 2. 2 e em II. 1. 6-9. 
mente os termos lógos e lógoi, mas também as linhas mais gerais da doutrina do lógos que age sobre a matéria, trazendo a ela forma, qualidade e movimento, e transpõe tal doutrina a um contexto platônico. Assim, nas Enéadas, o termo lógos aparenta-se à noção estóica e mesmo à aristotélica correspondente, de conteúdo racional, ou de essência, quando não tem os sentidos correntes de discurso, doutrina, faculdade racional, razão, ou mesmo relação matemática. Entrementes, para Plotino, este lógos, que é essência, e que age sobre a matéria, depende de uma forma que ele manifesta e torna presente. Dessarte, o lógos, neste trecho, corresponde ao movimento de passagem do Intelecto para a Alma em todos os níveis: Alma-hipóstase, alma do mundo, almas individuais.

Para Plotino, o lógos é um princípio de transmissão dos objetos de pensamento para a $\mathrm{Alma}^{7}$. Nos seus diferentes níveis, os lógoi parecem manifestar-se da seguinte maneira: no Intelecto, o lógos corresponde às formas. Estas se encontram todas juntas, em uma simultaneidade absoluta, posto que o Intelecto é eterno e todo conhecimento é simultâneo e imediato. $\mathrm{Na}$ Alma, os lógoi se apresentam de modo discursivo, separados uns dos outros, à semelhança de como aparecem no pensamento discursivo em um raciocínio, ou

7. "Há apenas uma razão e ela vem diretamente do Intelecto na Alma. É o lógos saído do Intelecto que faz na Alma com que ela pense, pois é privilégio exclusivo do Intelecto conter os inteligíveis e, na verdade, de ser idêntico a eles. O lógos só pode ser um princípio (em amplo sentido) de transmissão dos objetos de pensamento à Alma” (TURLOT, 1985, 518). Ver II, 9 [33] 1, 32. 
no nível da linguagem humana em uma frase ou em um discurso ${ }^{8}$. Ao nível da alma do mundo, os lógoi parecem cumprir a função organizadora da matéria, a fim de formar o mundo?. Conforme Plotino, essa organização corresponde ao reflexo na matéria da estrutura do mundo inteligível, por intermédio dos lógoi que, nesse plano, são eles próprios imagens das formas. Mas, igualmente, uma vez que a alma, em todos os níveis, possui uma parte que fica ligada ao Intelecto, contemplando-o, enquanto a outra parte, que é a produtiva, volta-se para o que lhe vem a seguir, os lógoi também desempenham a função de garantia da permanência dessa ordem, o que pode ser expresso pela noção de providência.

Aqui cabe um comentário sobre a questão da divisibilidade da Alma. Plotino considera que a Alma é indivisível por natureza, mas que se divide nos corpos. Porém, mesmo nos corpos, a alma permanece indivisível ${ }^{10}$. Sendo assim, como entender o caráter divisível da Alma? A solução, proposta pelo próprio Plotino, é que a Alma não desce efetivamente, mas sim o que desce é uma imagem da Alma, ou um reflexo

8. "Com efeito, tal como o discurso (lógos) que se manifesta na voz é uma imitação daquele que se encontra na alma, também o que está na Alma é imitação de um outro. Portanto, assim como a palavra proferida é fragmentada se o comparamos àquela que se encontra na alma, do mesmo modo também o é o que está na alma, que é intérprete daquele, se comparado ao que encontra antes dele" (I, 2 [19] 3, 27-30).

9. Há uma passagem importante onde Plotino explica como o mundo é produzido: IV, 3 [27] 10, 10-42.

10. Esta aporia é exposta, por exemplo, no brevíssimo tratado IV, 1 [21]. 
(BLUMENTHAL, 1971, 15 ss) ${ }^{11}$. Podem-se citar, a propósito, duas passagens do tratado V, 9 [5]: na primeira, Plotino afirma que a forma que se encontra nas coisas sensíveis é imagem (eidōlon) da forma real sobre a matéria $(\mathrm{V}, 9$ [5] 5, 17). A segunda parece ainda mais clara: os corpos e o mundo sensível participam de imagens (indalmátōn metékhon - V, 9 [5] 5, 42). Essas imagens da Alma que se encontram no sensível, parecem ser os lógoi que se difundem na matéria. Através dessa noção, pode-se entender que a Alma não se divide efetivamente, mas como que um eflúvio dela parte em direção à matéria, refletindo-se em cada corpo e em cada parte do corpo. Porém, é preciso cuidar em não tomar os corpos sensíveis por meros reflexos projetados na matéria. Os corpos têm uma vida própria, manifestando em relação ao seu princípio um desejo que o estatuto de imagem nem sempre deixa explícito ${ }^{12}$.

Certamente, tal descrição do lógos é muito sumária, mas permite perceber que ele surge tanto do movimento de conversão da Alma em direção ao seu princípio, o Intelecto, como do movimento de processão do Intelecto em direção à Alma e, por extensão, ao mundo sensível. Cabe ainda notar que o lógos não é engendrado como uma realidade hipostática, mas ele é

11. O vocabulário referente a esta imagem que desce compreende termos como: eidōlon, indalma, éllampsis. Este último termo aparece em Plotino também na forma éklampsis.

12. Tal questão será retomada à frente, em Discursos miticos. Esse tema do desejo amoroso pelo princípio como movimento ascensional, em contraste com a difusão de lógoi, como movimento processional, é versado em Discursos sobre Afrodite e Eros. 
o produto conjunto do Intelecto, que é sua fonte, e da Alma, que é seu lugar ${ }^{13}$. O lógos difunde-se por todas as dimensões ontológicas; por conseguinte, através da noção de lógos podem-se entender dois princípios básicos e fundamentais da filosofia plotiniana: 1) há uma implicação mútua entre contemplação e produção ${ }^{14}$; 2) não há uma verdadeira cisão entre o produto e sua causa. A Alma não está de todo separada do Intelecto exatamente porque nela os inteligíveis se encontram sob o modo de lógoi. Ademais, os lógoi estão presentes em todos os planos da realidade, até mesmo na mais ínfima pedra, assegurando um elo entre os inteligíveis e os corpos sensíveis. Dito em outros termos, os corpos participam da forma, na medida em que possuem lógoi. Cabe ainda observar que, na alma humana, os lógoi constituem o princípio do raciocínio; nos corpos, eles aparecem como qualidades, que são apreensíveis pela sensação.

Posto isso, pode-se observar que na filosofia de Plotino, tanto a processão das coisas do Um, como o retorno ao Um, devem perfazer as mesmas etapas do

13. "Digamos, então, de novo com maior precisão, qual é esse lógos e como é sensato que ele seja tal. Esse lógos, portanto - ousemos, pois talvez o alcancemos! -, pois bem, ele não é um intelecto sem mescla, nem o Intelecto em si, nem tampouco é da família de uma Alma pura, pois dela depende e é como que uma irradiação de ambos: do Intelecto e da Alma, isto é, da Alma disposta em conformidade com o Intelecto, pois ambos engendraram esse lógos como uma vida que contém em quietude um certo lógos" (III, 2 [47] 16, 10-17 - trad. Baracat Jr., ligeiramente modificada).

14. Foi visto que o lógos é produção, na medida em que transmite forma à matéria, mas igualmente Plotino diz que o lógos é contemplação em III, 8 [30] 3, 3. 
caminho. Assim, o homem, estando no mundo sensível, deve desligar-se do sensível e voltar-se para o inteligível. Somente quando a alma humana contempla o Intelecto, torna-se capaz de contemplar o Um. Ora, o caminho ascensional é, a bem da verdade, um caminho de interiorização da alma. Plotino descreve esse caminho nos capítulos sete a onze do tratado VI, 9 [9], exatamente onde aparece a metáfora do templo e das esculturas. Estabelecidos esses breves pressupostos, pode-se então passar ao estudo das metáforas e dos termos em questão.

\section{DO TEMPLO E DA ESCULTURA}

Sabe-se que a metáfora opera uma transferência de sentido: uma palavra passa a significar algo diferente do seu sentido imediato. Assim, é claro que o templo, para Plotino, não significa exatamente a construção arquitetônica que tem uma função religiosa, a de cultuar os deuses. Porém, para se compreender uma metáfora, o sentido corrente é útil, na medida em que nenhuma metáfora é ingênua. Logo, se o templo representa um determinado aspecto da experiência unitiva da alma, nas Enéadas, é interessante observar, doravante, o que esse edifício significa para o mundo romano helenizado, onde vive Plotino.

Como é consabido, o templo grego tinha o propósito de abrigar um deus, e não apenas de congregar e acomodar os devotos para o culto ao deus. Com efeito, para os helenos, o deus vem habitar permanentemente o templo, por intermédio da grande escultura cultual antropomórfica que lá se encontra (VERNANT, 1990, 57). Não por 
acaso, a palavra grega neốs cuja forma ática é naós designa precisamente a casa de um deus, ou ainda a parte interior do templo, onde fica a escultura. Conservando o plano tradicional, a forma de templo, que se tornou canônica, possuía um pórtico de entrada, cujo telhado normalmente era sustentado por duas colunas, e uma cela central, que era um grande salão ao fundo do qual se encontrava a escultura representando o deus a quem pertencia o templo. Essa estrutura era cercada por uma colunata externa, o pteroma, que formava uma ala cercando as paredes do templo. Ainda havia, no interior do templo, um local reservado aos sacerdotes, o chamado ádito ${ }^{15}$.

Plotino faz referência ao templo, sob o termo neốs, em dois tratados apenas, VI, 9 [9] e o imediatamente seguinte na ordem cronológica, V, $1[10]^{16}$. Em ambos

15. É evidente que, ao longo dos tempos, os detalhes dos templos foram mudando. Assim, por exemplo, as colunas vão ficando cada vez mais esguias e espaçadas, e os capitéis têm seu tamanho diminuído em relação ao fuste. Os historiadores da arte em geral consideram que esse processo de afinamento das colunas encontra seus limites no século II d.C., graças à natureza das estruturas, que passam a permitir tal adelgaçamento. Afora isso, o que regia a construção dos templos, do ponto de vista conceitual, eram as regras da harmonia, da simetria e do equilíbrio que se encontravam estabelecidas no cânone de Policleto, e isso persistiu ao longo de toda a civilização helênica. Pode-se considerar que tais características gerais da arquitetura dos templos sejam suficientes para seguir finalmente com a análise da metáfora do templo. Para a descrição geral dos templos, ver LAWRENCE (1998, 58 ss).

16. Sob o termo hierón encontram-se as seguintes ocorrências significando templo: I, 6 [1] 7, 6; 8, 2; IV, 3 [27] 11, 2; V, 8 [31] 6, 7. $\mathrm{O}$ sentido da metáfora permanece o mesmo nessas ocorrências. 
os tratados, o templo representa a mesma coisa. Desse modo, pode-se começar estudando as imagens do templo em VI, 9 [9]:

Não apenas as coisas belas, mas também o belo já sobrepujado, tendo já também passado por cima do coro das virtudes, é (hốsper) alguém que penetrou no interior do adito (adýtou), deixando para trás as esculturas do templo (töi neöi agálmata), as quais, saindo novamente do ádito, são as primeiras que vê depois da contemplação no interior (VI, 9 [9] 11, 18-20 - trad. Brandão, modificada $)^{17}$.

17. A tradução de Bernardo Brandão foi modificada a fim de manter a coerência interna do texto, em todos os lugares onde ocorre o termo ágalma, o qual ele traduz por estátua, e aqui se usa escultura, e do termo ádytos, o qual ele traduz por "santuário". Efetivamente, é preferível, para a presente análise, manter a terminologia técnica da arquitetura grega, que se firmou a partir do século XIX, quando o termo ádito passa a designar, nas línguas modernas, a parte reservada, interna do templo. Com efeito, "ádito" refere-se a uma parte do templo à qual normalmente só tinham acesso os sacerdotes. Não obstante, a pitonisa de Delfos revelava os seus oráculos no ádito do templo de Apolo. O termo grego ádytos significa literalmente "lugar sagrado, impenetrável, inacessível aos profanos”. Observe-se que, na língua grega préhelenística, o termo ádito é usado para designar o lugar onde ocorrem a inspiração oracular e a profecia, não se aplicando exclusivamente ao âmbito do templo, mas também a uma caverna ou a um lugar subterrâneo, por exemplo. Para o significado de ádito, em referência às câmaras mais internas, secretas do templo, ver HOLLINSHEAD (1999, 189-218). 
Plotino menciona dois lugares, a cela do templo, onde estão as esculturas, e o ádito; ora, isso talvez signifique que adentrar seu interior exige um longo percurso de purificação pelas virtudes. Por isso, no começo da passagem, Plotino diz que quem penetra no ádito já passou pelo coro das virtudes. O coro é uma metáfora recorrente nas Enéadas, representando, como foi visto, a participação das coisas na unidade. Ora, "coro das virtudes" possivelmente refira-se às formas das quatro virtudes, que, embora possua uma unidade - o ser virtude - a qual se revela na implicação mútua entre todas ao nível do Intelecto, ainda guarda um caráter de multiplicidade, na medida em que são diferentes formas de quatro virtudes distintas: a sabedoria, a justiça, a coragem e a temperança. Ademais, nessas primeiras linhas em que as metáforas do templo e das esculturas aparecem, nota-se uma estratégia de correção da linguagem, bastante frequente em Plotino: a restrição semântica. Aqui se tem hốsper, mas, além deste, pode-se encontrar outro advérbio com a mesma função retórica nas Enéadas, hoîon, cuja função é transportar uma palavra ou expressão do uso habitual para um outro, normalmente difícil de expressar através da linguagem proposicional ${ }^{18}$.

18. "Plotino não desconhecia a falácia da linguagem humana e da sua também. Por isso, constantemente se esforçava por tentar corrigir o pensamento, introduzindo o advérbio hoîon, conforme já foi dito. Esta palavrinha tem o condão de transportar o pensamento a novos patamares, até as fronteiras do indizível, onde impera o reino do silêncio, na imutabilidade da solidão do Um” (ULLMANN, 2002, 91). 
Diante da advertência de que as palavras "esculturas", “ádito" e "templo" não devem ser compreendidas no seu sentido literal, é importante tentar estabelecer as devidas correspondências, a fim de buscar-lhes o significado. Em primeiro lugar, na sentença supracitada, Plotino estabelece uma comparação assimétrica entre, de um lado, as coisas belas, o belo sobrepujado e o coro das virtudes e, de outro lado, as esculturas e o ádito do templo. Todavia, a dessimetria não parece residir na comparação entre os três termos anteriores a hốsper e os outros dois, seguintes. Com efeito, os três elementos que precedem hốsper são representados pelas esculturas, não por acaso no plural. Tanto esse excesso de termos, por assim dizer, como o plural parecem aludir à multiplicidade interna a qualquer plano de realidade, excetuado o Um, que é isento de qualquer multiplicidade. As linhas seguintes da passagem permitem entrever isso mais claramente:

E a convivência de lá não é com uma escultura ou imagem (eikóna), mas com ele. Estas vêm a ser uma contemplação secundária. $\mathrm{E}$ isso talvez seria, não contemplação, mas uma outra forma de ver, êxtase, simplificação e um aumento de si, desejo de contato, repouso e consideração de uma harmonização, se alguém vier a contemplar o que está no ádito (VI, 9 [9] 11, 21-25 - trad. Brandão).

O ádito parece, com efeito, representar o nível mais profundo da contemplação, ou seja, aquele em 
que a alma vive o contato com o Um. As esculturas, que aqui são assimiladas à noção de imagem, representam por sua vez uma contemplação secundária. O que isso significa? Com efeito, como já foi visto, a experiência unitiva da alma se dá em duas etapas. A condição para que a alma una-se ao Um é que antes ela esteja unida ao Intelecto. Quer dizer que não é possível passar do pensamento discursivo, característico da alma, para o Um sem que antes o pensamento discursivo converta-se em pensamento puro. $\mathrm{Ou}$, visto sob outro ângulo, não é possível sair da dimensão mais elementar das virtudes, as cívicas, ao Um revelado através da unidade da forma das virtudes, sem antes passar pelos níveis da purificação, nos quais a alma desliga-se do sensível e contempla o inteligível, entrevendo as formas das virtudes. O caso das virtudes parece ser o que melhor define a progressão da alma até o Um, pois se percebe claramente que é necessário percorrer um longo caminho que implica em uma mudança de um modo de vida para outro, através da purificação pelas virtudes, até que a alma contemple no Intelecto as formas das virtudes, tornando-se então semelhante a deus, isto é, ao Intelecto ${ }^{19}$. Somente então

19. O ponto de partida do tratado I, 2 [19], Sobre as virtudes, consiste exatamente na retomada de uma passagem do Teeteto, $176 \mathrm{a}-\mathrm{b}$, com ênfase precisamente em duas imagens: a fuga do mundo sensível, que de fato corresponde a uma transformação da vida, e ao assemelhamento a deus. Théos neste caso representa o Intelecto (I, 2 [19] 6, 6-7) ou, ainda, as virtudes superiores (I, 2 [19] 6, 7-8). 
é possível contemplar o Um através da unidade interna do Intelecto ${ }^{20}$.

Assim, parece que na metáfora do templo a parte do edifício onde se situam as esculturas corresponde à contemplação do Intelecto, enquanto a contemplação do que está no ádito, ou seja, do próprio deus invisível que habita o templo corresponde à união com o $\mathrm{Um}^{21}$. Mas, cabe assinalar a surpresa: Plotino não se referia ao Intelecto pelo termo deus? Como pode a contemplação do deus invisível corresponder à união com o Um? Uma metáfora, assim como um mito, pode ser polivalente nas Enéadas. E tal polivalência parece denotar alguma relação entre os possíveis significados. No caso do termo deus, aqui entendido metaforicamente, parece remeter à continuidade entre o Um e o Intelecto, ou ainda à unidade presente no Intelecto, cuja causa é o Um. Além disso, é importante reiterar que não há contemplação do Um sem haver contemplação do Intelecto. A bem da verdade, a contemplação do Um parece ser o foco em um ponto preciso

20. Em V, 1 [10] 6, 11- 15, a metáfora do templo mostra resumidamente o que vem a ser investigado.

21. Em acordo com Fronterotta (in: PLOTIN, 2003, n. 182, 128), pode-se dizer que as esculturas são apenas imagens da divindade, a qual se encontra no interior do ádito. Antes de lá entrar, para contemplar a própria divindade, é necessário passar pela entrada do templo, onde estão as esculturas, objeto de uma contemplação secundária, pois a verdadeira contemplação é aquela cujo objeto é o Um. Nesse sentido, a entrada no templo corresponde à passagem do mundo sensível ao inteligível, enquanto a entrada no ádito corresponde à passagem do inteligível ao Um, situado além e antes de todas as coisas. 
no cerne da totalidade das formas em que consiste o Intelecto. Isso pode ser explicado através de outra bela metáfora das Enéadas, bastante conhecida: há algo como um centro em torno do qual há um círculo de luz, em torno deste há um outro círculo de luz; luz saída de luz, diz Plotino. Em torno destes, um outro círculo que não possui luz própria, mas depende da luz de outro. O centro parece ser o Um, os três círculos são o Intelecto, a Alma e a esfera do mundo (IV, 3 [27] 12 ss). No êxtase, isto é, no momento da união com o Um, é como se o centro da Alma coincidisse com o centro universal (VI, 9 [9] 8, 1-7), tal como os centros dos círculos de uma esfera coincidem com o próprio centro da esfera que os compreende (VI, 9 [9] 8, 20-22). Mas afinal, há um centro da Alma distinto do Um? Aqui é preciso notar uma sutileza: o centro da Alma não é o próprio Um (VI, 9 [9] 8, 10-11), pois se o fosse, o Um seria diretamente presente à Alma, sem que ela necessitasse torná-lo presente. O Um, se é o centro, só pode constituir o ponto com o qual o centro da Alma se confunde. Através da coincidência dos dois centros, a presença do Um na Alma torna-se efetiva. Portanto, a metáfora dos círculos torna dois tipos de presença manifestas: de uma parte, o Um está presente enquanto centro de tudo, mas só é possível torná-lo presente encontrando cada qual o próprio centro, isto é, a unidade original para coincidir com ele (ROUX, 2004, 264). Portanto, a coincidência do centro da Alma com o centro de tudo supóe um parentesco (tôi syngenề - VI, 9 [9] 8, 29) entre a Alma e o Um: "O Um produziu um ser aparentado com 
ele, e é tornando-se este ser que nós fomos, que nós apreenderemos o Um. O desejo do Bem que permite a presença da Alma no Um pressupóe uma causalidade eficiente da parte deste último" (ROUX, 2004, 266). Entrementes, ainda é importante observar que a união da alma com o Intelecto e com o Um também representa uma mudança do modo de ver. Exatamente essa questão também é posta a lume, através da metáfora dos círculos e reaparece com a metáfora do templo. É que quando a alma vê o Um, de fato "nem vê, nem distingue, nem imagina dois, mas como se viesse a ser outro, e não ele mesmo, nem de si mesmo, pertence àquele lugar. E, vindo a ser daquele, é um, como um centro que coincide com outro centro" (VI, 9 [9] 10, 17- 18 - trad. Brandão).

A propósito, vale a pena tecer um breve comentário à metáfora da visão, recorrente nas Enéadas ${ }^{22}$. A origem dessa imagem parece remontar a Xenófanes, precisamente à expressão "deus vê tudo" (DIELSKRANZ, 24, I, 135). Mas ela desenvolve-se realmente nos escritos de Platão onde os exemplos do sentido figurado de horân e de skopeîn são de tal modo frequentes, que seria vão querer estabelecer uma lista, como observou Louis. Por sua vez, os verbos blépein e theöreîn aplicam-se seguidamente às operações intelectuais (LOUIS, 1945, 193). Com efeito, isso não significa que se vejam realmente as ideias: elas são

22. O vocabulário da visão é de tal modo recorrente nos tratados, que Ferwerda $(1965,127)$ não se furta de observar que isso quase faz o leitor esquecer que os termos que exprimem a visão constituem uma metáfora. 
concebidas, não vistas (PLATÃO, República, 507 b). Assim, a assimilação da ação intelectual e da ação visual é analógica. Outrossim, Platão, em certos diálogos, compara o conhecimento a uma iniciação, ao termo da qual, como nas religiōes de mistérios, o iniciado contempla a verdade ${ }^{23}$. Esta metáfora, a contemplação, para designar o conhecimento, pode ser a transposição de expressões correntes, tal como o uso de skopeîn no sentido de examinar. Mas também é possível que seja o resultado da influência de certas práticas dos mistérios eleusinos, como a ostentação dos objetos sagrados (LOUIS, 1945, 129).

Seguindo a linha de Platão, Plotino emprega essas metáforas da visão com respeito à contemplação dos inteligíveis e ao conhecimento; mas, através das mesmas imagens, ele também preconiza a fusão total com o Um. Assim, ele compara a Alma e o Intelecto ao olho e suas atividades à visão, como um ato contínuo e intemporal (VI, 1 [42] 16, 18) ${ }^{24}$. No tratado Sobre o belo, I, 6 [1], Plotino usa abundantemente as imagens do olho e da visão para explicar a ascensão da

23. Tal comparação pode ser vista no discurso de Diotima, no Banquete e no Fedro, 248 b ss. Em alguns casos, a comparação é um gracejo, por exemplo, quando Sócrates diz a Cálicles "Tu tens sorte de ter sido iniciado nos grandes mistérios antes de ter sido nos pequenos" (PLATÃO, Górgias, 497 c). Sobre o assunto, ver RIEDWEG (1987). Igualmente o terceiro capítulo de LOUIS (1945).

24. Ver o arrazoado das imagens e o comentário de FERWERDA $(1965,120 s s)$. 
alma rumo ao Um através da beleza (I, 6 [1] 9, 2-6) ${ }^{\mathbf{2 5}}$. Em linhas gerais, após ter sido despertada pelas belezas sensíveis, seja da arte, ou da natureza, Plotino afirma que a visão tem de se habituar aos poucos a ver, eis porque primeiro a alma deve ver as belas ocupaçôes, ver a alma dos que são bons, para enfim ver a si mes$\mathrm{ma}^{26}$. Nesse ponto, a visão passa a confundir-se com a contemplação. E a contemplação se dá na introversão $\mathrm{da}$ alma ${ }^{27}$. Essa visão interior é também designada pelo termo purificação, pois, para atingi-la, a alma percorre o caminho das virtudes, como já foi visto. Com efeito, Plotino associa o vocabulário da visão ao das virtudes, dizendo que, ao ver em si o esplendor da virtude e da temperança, o homem finalmente se vê purificado, e já não há obstáculo que o impeça de tornar-se um (I, 6 [1] 9, 16-17). Isso é expresso na metáfora do processo escultórico, que representa o próprio processo catártico da alma, como se pode ler em uma passagem bastante conhecida das Enéadas:

25. Plotino mesmo informa que a visão é empregada, significando sabedoria ou conhecimento. Em I, 6 [1], 4, 2, diz que saber é ver; recorre a uma paronomásia entre eîden e ồden.

26. Este tema é um pouco mais desenvolvido em um estudo anterior, do qual se seguem aqui alguns passos: OLIVEIRA (2005, 259-274).

27. "Estamos permanentemente, e sem saber, voltados para os inteligíveis, dos quais, o mais seguidamente, não temos a menor consciência, mais aos quais podemos nos tornar sensíveis. Se é necessário, então, um esforço, não é um esforço que nos permitiria transformar-nos, de nos tornarmos fundamentalmente outros além do que somos, mas é aquele que consiste em nos tornarmos nós mesmos adequados a nós mesmos” (MATHIAS, in: PLOTIN, 1991, 19). 
Como verias o tipo de beleza que uma alma boa possui? Recolhe-te em ti mesmo e vê; e se ainda não te vires belo, como o escultor de uma imagem (agálmatos) que deve tornar-se bela, apara isso e corrige aquilo, pule aqui e limpa ali, até que exibas um belo semblante na escultura, assim apara também tu todo o supérfluo, alinha todo o tortuoso, limpa e faz reluzente todo o opaco e não deixa de burilar a escultura de ti mesmo, até que resplandeça em ti o esplendor deiforme da virtude, até que vejas a temperança assentada em sacra sede (I, 6 [1] 9, 6-15 - trad. Baracat Jr., modificada).

É nesse sentido que normalmente se entende a mudança no modo de ver a que se refere Plotino: basta fechar os olhos e voltar a atenção para dentro de si mesmo, ou seja, mudar essa maneira de ver sensível por outra; despertar a visão que todos têm, mas que poucos usam (I, 6 [1] 8, 25-30). Em outros termos, para contemplar o Intelecto e o Um, é preciso, antes, se interiorizar e, descobrindo a unidade da Alma, ver através dela a unidade maior ainda do Intelecto, pois, somente através desta, é possível ver o Um. Parece ser então este o sentido da metáfora do templo e do ádito, onde finalmente se realiza a visão do Um, que talvez nem mesmo seja visão, mas contato ${ }^{28}$.

28. Não é surpreendente se, em muitos lugares, Plotino prefere as expressões "tocar" ou "contato" aos termos da visão, como observa Ferwerda $(1965,128)$. 
Se fosse ver de outro modo, nada estaria presente para ele. Essas coisas então são imagens (mimémata) e simbolizam (ainittetai) aos sábios entre os profetas de que modo aquele deus é visto. E o sacerdote sábio que compreende o enigma (ainigma) poderia, indo ao ádito, realizar a visão verdadeira. Isso mesmo que isso não aconteça e que não considere este ádito ser alguma coisa invisível, fonte e princípio, saberá que pelo princípio vê o princípio e que também o semelhante vem a estar com o semelhante (VI, 9 [9] 11, 25-32 - trad. Brandão).

Mas, na filosofia de Plotino todo caminho ascendente também possui uma via descendente, tudo depende da direção que se adota. Por exemplo, a visão do Um sobre si mesmo produz o Intelecto; o olhar deste para o Um produz a Alma; o olhar da Alma para o Intelecto e, através deste, para o Um, produz o mundo sensível. No mundo sensível, a alma humana, vendo as formas inteligíveis refletidas nos corpos, pode entrever, através dela, a si mesma, enquanto parte ou imagem da Alma, o Intelecto e, finalmente, o Um. Ver as formas aqui signifca perceber a beleza sensível, pois quem é capaz de reconhecer, na beleza sensível, um traço da beleza inteligível identifica a forma da beleza. Assim, diante do belo inteligível, passa a amá-lo. Amante, purifica sua alma, apercebendo-se que o belo tem a mesma origem que sua alma e que ambos remetem ao Um/Bem (OLIVEIRA, 2005). Com efeito, 
para Plotino, o artista representa um tipo de homem dotado da capacidade de reconhecer no belo sensível o belo inteligível. E por isso pode fazer representaçōes sensíveis da beleza inteligível, objetos da arte nos quais o belo é reconhecível (II, 9 [33] 16, 40-49). Esse é, em síntese, o caminho erótico rumo à união com o Intelecto, e, a partir dessa, com o Um. Para trilhar este caminho, é necessário fugir das belezas sensíveis, que são como a feiticeira Circe ou a ninfa Calipso, de quem Odisseu foge para retornar à sua pátria (I, 6, 8, 15-21).

O belo, o amor e a dialética podem conduzir o homem rumo à unidade, como Plotino mostra no tratado I, 3 [20], Sobre a dialética. O mito, conforme a hipótese de trabalho em torno da qual se articula este estudo, situa-se no meio-termo entre as imagens da arte e os discursos. Pode, portanto, cumprir uma função anagógica afetiva, entendido como figura. Como discurso, pode ser submetido às operações dialéticas de divisão e síntese, oferecendo-se, pois, a um outro caminho ascensional. Não significa que o mito ele próprio seja um caminho, mas sim que ele é um instrumento passível de indicar o caminho ${ }^{29}$. Partindo, pois, dessas páginas propedêuticas acerca da filosofia de Plotino, é possível agora passar ao estudo dos discursos e das figuras míticas, tecendo preliminarmente um comentário acerca dos discursos nas Enéadas em geral.

29. Portanto, também é um instrumento didático, considerando que o filósofo parece ter por função indicar o caminho para aquele que, no rumo, encontra-se perdido (I, 3 [20], 3, 3-4). 


\title{
TIPOS DE DISCURSO
}

\begin{abstract}
A pós a breve exposição da filosofia de Plotino, no - capítulo anterior, este apresenta certas estratégias discursivas dos tratados das Enéadas, com o escopo de, ulteriormente, definir-se a especificidade dos mitos. Há um pressuposto básico que norteia os discursos de Plotino em geral: tentar mitigar o hiato entre o sensível e o inteligível, para poder, enfim, estar em condiçôes de contemplar o Intelecto e, posteriormente, o Um. Portanto, no contexto mais amplo da filosofia entendida como um modo de vida, todo discurso filosófico objetiva fazer a alma encarnada em um corpo assemelhar-se ao Um. O problema que se impõe é a inefabilidade do princípio e a inadequação da linguagem a ele. Mas será somente a ele? Será que os discursos são capazes de atingir o Intelecto?

Tais indagações conduzem à pergunta acerca da origem da linguagem, pois, ainda que tudo tenha o Um por princípio, nele não existe dualidade, logo não
\end{abstract}


pode haver linguagem. Com efeito, as coisas de ordem sensível passam por dois intermediários, o Intelecto e a Alma. A linguagem humana origina-se, pois, na Alma, ou sua origem remonta ao Intelecto? A questão da origem, que fora sugerida pela dos limites da linguagem, é, portanto, tratada conjuntamente a esta, quando se investiga a linguagem apofática. Mas, pari passu com a via negativa, Plotino também possui discursos afirmativos. A linguagem catafática, com efeito, é muito rica nas Enéadas, não sendo possível, no âmbito deste estudo, investigá-la sob todos os seus aspectos. Portanto, objetivou-se tratar apenas de certos recursos que tangem ao mito, tais como a persuasão, a restrição semântica e a analogia. Através desses, é possível perceber que os discursos conduzem à sua origem, o Intelecto, apontando para o que está além, o Um.

Além disso, os recursos da linguagem catafática estudados propóem outra abordagem dos discursos das Enéadas, especificamente dos míticos: seu aspecto retórico. Isso parece supor que Plotino redigiu os tratados, tendo cuidado da composição literária. Para tanto, é útil a classificação proposta por Hadot, segundo a qual os procedimentos discursivos de Plotino podem ser divididos em dois grupos: a dialética e a retórica. A dialética é entendida como um diálogo entre interlocutores anônimos nos textos. Assim compreendida, ela reflete, na verdade, dois aspectos da prática escolar plotiniana: o comentário de textos, que é um diálogo entre o exegeta e o texto, e a própria situação didática, na qual os alunos fazem perguntas ao mestre. A retórica é caracterizada como um discurso contínuo, no qual o 
mestre tenta convencer seus interlocutores de uma tese. Para tanto, ele pode servir-se de vários artifícios, como certas figuras de estilo e de linguagem. Dentre as figuras mais comuns, nas Enéadas, encontram-se as metáforas e os mitos, que tentam explicar algo obscuro. Ou tentam apontar para algo que não pode ser dito adequadamente, através de outras formas discursivas, servindo como elementos de correção da linguagem. Mas elas próprias precisam ser verificadas para não induzir o interlocutor a permanecer com o sentido primeiro, desviando a alma do verdadeiro sentido. A retórica serve também à linguagem apofática. Finalmente, a retórica possui uma carga afetiva, que move eroticamente o interlocutor rumo ao objeto do discurso.

\section{ORIGEM E LIMITES DA LINGUAGEM}

A discussão sobre a origem da linguagem praticamente não ocupa Plotino. Entretanto, há uma passagem na qual ele alude ao que ocorre com o som: quando é pronunciada a palavra "ser" (heînai) forçando a pronúncia (enapereísantos), faz-se com que seja ouvido o som "um" (hén), que designa a origem no Um, e o som "que é" (ón), que significa o que produz o som (V, 5 [32] 5, 19-21). Essa passagem, considerada de difícil interpretação, porquanto Plotino usa artigos e pronomes cujos referentes são maldefinidos, suscita de imediato uma questão: quem pronuncia esses sons? Henry e Schwyzer consideram que é o Intelecto. Entretanto, é possível que seja apenas um alguém indefinido, tís (DUFOR, in: PLOTIN, 
2006, n. 73, 171) ${ }^{1}$. Ora, considerando a hipótese de que Plotino tende a um certo "henologismo" linguístico, toda vez que uma palavra for pronunciada por alguém, ela representará a sua origem, refletindo o que ela verdadeiramente é. Mas é preciso estar atento, pois Plotino não adere ao que se poderia entender como uma posição naturalista ingênua, que suporia uma relação direta entre a palavra e o objeto, na qual, ao falar de uma coisa, diz-se a própria coisa.

Então, de que modo se pode compreender o henologismo linguístico? Em outros termos, qual a origem das palavras, segundo Plotino? É sobre o que versa a sequência da passagem, a qual se pode glosar da seguinte maneira: aquilo que é engendrado, a essência e o ser ( hè ousía kaì tò eînai), possui uma imitação do Um, porque provém dele, e uma imitação da essência, pois contempla o Um e, incitado pela contemplação, tenta imitar o que vê, pronunciando estas palavras: "que é" (ón), "ser" (tò eînai), essência (ousían) e lugar (hestían). Essas palavras, pois, significam a vinda à existência de quem as pronuncia, depois de terem sido paridas dolorosamente, imitando, assim, como podem, a gênese do que é (V, 5 [32] 5, 19-28). Plotino não dá sequência a essa questão da origem das palavras, deixando a interpretação em aberto, com uma fórmula bastante recorrente nas Enéadas, "interprete isto como quiser". Mas fica claro que as primeiras palavras surgem no Intelecto, no ato da contemplação do Um.

1. Para uma discussão mais pormenorizada das duas posições, a de Henry e Schwyzer e a de Ferwerda, que opta por alguém. 
Bem, um outro ponto que parece interessante observar nesse passo é a proximidade entre as primeiras palavras proferidas pelo Intelecto e alguns jogos etimológicos do Crátilo. A dupla ousía e hestía aparece em $401 \mathrm{c}$-d, onde a essência das coisas é chamada lugar. A noção de imitação (mímèsin) parece ser uma alusão a $431 \mathrm{~d}$, onde as sílabas e as letras das palavras imitam a realidade das coisas. Essa passagem, enfim, permite entrever que fundamentalmente Plotino admite o uso de etimologias, na medida em que ele assume uma postura que se pode chamar henologista. Portanto, as palavras originam-se do ato contemplativo do Intelecto em direção ao Um e, em última instância, do próprio Um, o qual elas tentam imitar. Por conseguinte, a relação de continuidade entre as palavras e as coisas é assegurada pela presença do Um, através do lógos, em cada nível ontológico. Por outro lado, uma vez que se originam no Intelecto, as palavras podem dizer o que é o ser e a essência da coisa. Mas conseguem dizer o que é o $\mathrm{Um}^{2}$ ?

Formulada de outra maneira, a questão é: a linguagem encerra sua atividade no Intelecto? Ou será possível discorrer sobre o Um de alguma maneira? A linguagem, com efeito, constitui uma mediação pela qual a alma deve necessariamente passar na sua pesquisa sobre a natureza do inteligível e do $\mathrm{Um}^{3}$. O problema que se

2. Não significa que há linguagem proposicional no Intelecto, mas sim as formas que darão origem às palavras sensíveis e às proposiçôes.

3. Nesta discussão sobre a linguagem, tem-se por base os artigos fundamentais de SCHROEDER (1996, 336-355); O' MEARA (1990, 145-156); HOFFMANN (1997, 335-390); COLLETTE (2002, 78-82). 
impõe é justamente o teor sensível da linguagem, que pode deformar o inteligível e o Um, ao atribuir propriedades que são estranhas a esses domínios, exatamente por serem próprias do mundo sensível. Entrementes, o Intelecto, graças à sua multiplicidade interna, de certo modo, pode ser objeto do discurso. O Um, por sua vez, parece não permitir nenhum acesso discursivo, donde a tão mencionada questão, dentre os estudiosos de Plotino, da inefabilidade do Um. Mas ora, o próprio Plotino discorre a respeito das possibilidades de um discurso sobre o Um, salvaguardando sua inefabilidade:

Como, então, podemos falar dele? Dizemos sim algo sobre ele (perì autoû), mas não dizemos a ele próprio (ou mèn autó) e não temos dele nem conhecimento, nem pensamento. (...) De fato, dizemos o que ele não é; mas o que ele é, nós não dizemos. Falamos sobre ele a partir do que é posterior. Contudo nada impede que o tenhamos, sem o exprimir por palavras. Assim como os inspirados e os possuídos (hoi enthousiôntes kaì kátokhoi) vêem até certo ponto que têm em si algo maior que eles, eles não vêem o que é, mas de seus movimentos e das suas palavras, eles tiram um certo sentimento da causa que os move, ainda que esta seja bem diferente deles (V, 3, [49] 14, 1-13).

Com efeito, era corrente, à época de Plotino, afirmar que a causa suprema é incognoscível e inefável, como observa O’Meara (1990, 146-147; 1992, 71). 
Com respeito a isso, os platônicos podiam referir-se a diversas passagens de Platão, tais como Timeu 28c, onde é dito que o demiurgo é difícil de descobrir e impossível de conhecer. Ou República 509b: a forma do Bem está além do ser, mas o ser é cognoscível. Ou ainda, na primeira hipótese do Parmênides 142 a 3-6, segundo a qual não pode haver nome para o um. Mas, como nota ainda O’Meara, para Plotino, a inefabilidade do Um não é um simples lugar-comum, uma ideia recebida; Plotino afirma a inefabilidade do Um com base no estatuto do Um, que está para além de ser determinado, inteligível, cognoscível. Por isso, Plotino parece estabelecer uma distinção fundamental entre o discurso que fala sobre o Um (légei perì autô̂), e aquele que diz o Um (légei autó). Em um momento anterior, no mesmo tratado, Plotino distingue entre um sémainein perì autôิ e um sémaínein autó impossível (HOFFMANN, 1997, p. 344).

Conforme as análises de O’Meara (1990, 145-156), não é possível expressar o Um porquanto ele não é cognoscível segundo um conhecimento formal, mas ele está presente em nós, de tal modo que o discurso sobre o Um refere-se à própria natureza humana e à natureza do mundo. Portanto, o ser humano fala do estatuto metafísico que o caracteriza enquanto ser contingente ao falar sobre o Um. Quer dizer, ao falar sobre o Um (perì autôu), falamos de nós, da nossa condição de dependência causal que remete para além de si mesma. Tal condição revela a presença do Um em cada qual dentre nós. Assim, ao elaborar um discurso acerca do inefável, falamos, a bem da verdade, de uma presença em nós, 
que é dizível. Dessarte, a analogia dos inspirados e dos possuídos por um deus, que não deixa de ser um eco platônico de Íon, 533 e 6-7, parece representar, para Plotino, a manifestação dessa presença.

Todavia, é mister observar que Plotino admite duas possibilidades para se falar sobre o Um: através de formulações negativas e afirmativas. As negações consistem em recusar toda atribuição ao Um, enquanto as formulações afirmativas visam dizer aproximadamente o que o Um é, tentando assim mitigar a inadequação dos predicados. Portanto, elas exigem critérios de correção da linguagem, atentando para o fato de que todo discurso sobre o Um é, de certo modo, inadequado, ou ainda, impróprio. Segundo Plotino, transferir ao Um atributos, que pertencem a realidades inferiores, denota a impossibilidade de falar apropriadamente dele; portanto, é devido a essa impossibilidade que os discursos são impróprios (VI, 8 [39] 8, 3-6). É imediatamente na sequência dessas considerações que Plotino expõe o fundamento do discurso apofático, que reside exatamente na impotência, por natureza, do discurso para atingir a simplicidade absoluta do primeiro princípio. De tal modo que, nas palavras de Plotino,

Na realidade não é possível encontrar o que predicar dele, nem mesmo sequer o que dizer sobre ele com propriedade. Tudo o que é belo e venerável vem depois dele, pois ele é o princípio das coisas, mesmo que, em outro sentido, não seja princípio (VI, 8 [39] 8, 6-9). 
Este excerto também permite observar uma outra prática de correção da linguagem: Plotino predica algo do Um - o Um é princípio - para negar logo depois - em outro sentido, ele não é princípio. O significado filosófico disso, é consabido, vem em resposta a uma dificuldade maior que, aliás, o neoplatonismo em geral segue enfrentando, após Plotino, de pensar ao mesmo tempo a processão de todas as coisas do Um, que então é princípio, preservando o desligamento dele de todas as coisas, ou seja, sua simplicidade. Neste caso, ele não é princípio, porquanto permanece puro de qualquer relação, mesmo que substancial. Ademais, do ponto de vista da linguagem, esta passagem conduz a um problema central, o dos limites da linguagem predicativa, quando o objeto é o Um. Uma pergunta inevitavelmente surge: Se o Um é incognoscível e indizível, se, enfim, a linguagem não o abarca, se, ao contemplá-lo em um momento único e irrepetível, um kairós ${ }^{4}$, onde

4. Sobre a noção de kairós, é preciso observar que o Um é acrônico, afinal ele não pode se submeter a um devir, ou seja, a uma multiplicidade, a uma sucessão de instantes. A multiplicidade, ela sim provém da unidade. Por conseguinte melhor seria dizer que o Um é anterior ao tempo (VI, 8 [39] 14). Menos evidente é que o Um também é anterior à eternidade, ou nas palavras de Guitton (1959, 12), "o Um transcende a eternidade, que seria um princípio de determinação". De fato, ainda que use o termo eternidade para aludir à autoprodução do Um, Plotino o faz não corretamente, ou seja, ciente do uso de uma linguagem não exata para falar acerca do Um inefável. Em VI, 8 [39] 18, 44-54 aparece um termo mais apropriado para manifestar discursivamente esta "atemporalidade" do Um: kairós. Se a acronia do Um é da ordem do kairós, a contemplação inevitavelmente deve se dar 
nem o pensamento, nem a consciência de não pensar estão presentes, onde aquele que contempla fundese ao contemplado e torna-se ele próprio um, então não seria paradoxal falar do Um? Ou ainda, diante dessas dificuldades, para não dizer impossibilidades semânticas, se está condenado ao silêncio? Não, pois o Um é o que permite à linguagem tomar consciência dos seus limites. Por isso, incita a linguagem a inventar modos discursivos apropriados, que não façam do princípio um objeto em si, ou um ser inteligível múltiplo, mas tão-somente "um objeto do discurso, um objeto que é necessário sustentar pelo discurso e na consciência dos limites deste discurso" (COLlETTE, 2002, 74).

Com efeito, a linguagem catafática vem acompanhada por um modo particular de reflexividade, designada pela expressão kat'epinoian, que significa "pensar a partir das coisas sensíveis, sem reduzir aquilo de que se fala ao sensível", como diz Couloubaritsis $(2000,649)$. De tal sorte que, como ainda observa o estudioso, o discurso de Plotino é seguidamente submetido à regra segundo a qual só é possível falar daquilo que nos escapa "como se" fosse assim, sabendo que não é assim. Este tipo de pensamento é seguidamente sinalizado pelas partículas hoîon ou hôs, cuja presença conduz a uma reflexão sobre a função e, ao mesmo tempo, os limites da

"kairoticamente", pois no ato contemplativo não há distinção entre contemplante e contemplado. Sobre o tema do kairós em Plotino, pode-se consultar ainda: COULOUBARITSIS (1997, 89-107) e LACROSSE $(1997,75-87)$. 
linguagem catafática. Além disso, com elas Plotino de certo modo purga a linguagem abolindo dela as conotações humanas, impróprias para o Um, tanto quanto possível. Por conseguinte, a tentativa de adequação da linguagem passa por uma abundância de fórmulas que sobrecarregam a frase, paradoxalmente à simplicidade que ela tenta expressar (BELAYCHE, s/d, 26). Por outro lado, o uso da forma adverbial hô̂on permite observar dois outros aspectos da linguagem catafática: a analogia e a persuasão.

\section{A ANALOGIA}

Há circunstâncias, ao longo das Enéadas, em que Plotino emprega hoîon como sinal de analogia. Por exemplo: o filósofo tem, por assim dizer (hô̂on), asas (I, 3 [20] 3, 2). Ou, os seres são, por assim dizer (hoîon), a matéria da dialética (I, 3 [20] 5, 12). Nestes dois breves exemplos, não parece ser difícil perceber a analogia. Do mesmo modo, geralmente nos mitos verifica-se a relação de analogia entre a figura mítica e a realidade metafísica por ela representada. Mas o que é analogia para Plotino? Em um estudo dedicado ao tema, Chrétien (1989, passim) observa, por primeiro, que as ocorrências do termo analogia (analogía) nas Enéadas são bastante raras, apenas 17, e o uso do termo é disperso, e mesmo disparatado. Não se encontra, portanto, em Plotino, algo como uma teoria da analogia. Tampouco se encontra uma analogia do Um ou do Bem expressis verbis, a não ser, de certo modo, em uma passagem onde são evocadas as "analogias do 
simples" 5 . Tempos depois de Plotino, Proclo, por sua vez, tematizará a analogia em um capítulo decisivo da Teologia Platônica, fazendo com que a via analógica corresponda à conversão, enquanto a via negativa corresponde à processão, evidenciando que o Um não é nada daquilo que dele procede (PROCLO, Teologia Platônica, II, 1, 15-18) ${ }^{6}$. A analogia, então, para os platônicos tardios afigura-se como um pensamento de mediação, de séries, e de intermediários. Embora o tema da analogia não seja explicitamente desenvolvido nas Enéadas, parece haver algo de semelhante com o sentido conferido por Proclo, isto é, as analogias em Plotino afiguram-se como que degraus (anabasmoi).

Tomando como exemplo a questão do belo para compreender a analogia nas Enéadas, observa-se primeiro que a beleza sensível não é exatamente a mesma que a beleza inteligível, isto é, a forma de onde se origina. Por conseguinte, não parece haver uma relação sinonímica de termos, quando aplicados, seja ao corpo sensível, seja ao nível inteligível, mas homonímica. Ora, a homonímia por vezes confunde-se com a analogia em Plotino. Com efeito, ao explicar que a beleza sensível nada mais é do que um reflexo da inteligível, Plotino cuida para não estabelecer uma equivocidade. Mas até onde a analogia conduz? O belo verdadeiro, isto é, a forma da beleza, reside no Intelecto. $\mathrm{O} U \mathrm{U}$ é dito belo além do belo

5. "Mas essas coisas (o ponto e a mônada), serão sempre semelhantes àqueles (o um e o sem partes) por analogia, pelo simples e pela fuga da multiplicidade e da divisão" (VI, 9 [9], 5, 44-45 - trad. Brandão).

6. Antes de Plotino, o tema da analogia pode ser estudado em Alcíno, no capítulo X do Didaskalikos. 
(kállos hypèr kállos - VI, 7 [38] 32, 29), ou ainda belo que produz belo (kállos kallopoión - VI, 7 [38] 32, 32). De fato, Plotino adverte: o Um é potência de cada coisa bela (dýnamis oûn pantòs kaloû), ele é princípio (arkhế) e termo (péras) da beleza, mas não como uma forma, pois ele não é forma. Ele é princípio, porquanto a beleza, assim como tudo o que há no Intelecto, procede dele (VI, 7 [38] 32, 3-40). Nas palavras de Plotino,

\begin{abstract}
Assim, em um discurso impreciso (holoskherêิ mèn lógoì), ele é a beleza primária; mas, se se distinguem os inteligíveis, se dirá que a beleza inteligível é a região das formas, ao passo que o Bem é o que está além, fonte e princípio do belo. Caso contrário, o Bem e o belo primário seriam identificados; de qualquer modo, o belo está lá (I, 6 [1] 9, 39-43 - trad. Baracat Jr.).
\end{abstract}

Conforme Chrétien, a analogia própria, isto é, verdadeira, se conclui no Intelecto, mas um tipo de analogia designada de proporcionalidade imprópria, que é metafórica, essa sim, pode ser aplicada ao Um.

\title{
3. A PERSUASÃO
}

Com efeito, hoîon é particularmente usado no tratado VI, 8 [39], em especial quando Plotino passa do registro apofático para o catafático. Portanto, ele necessita indicar que os atributos do Um não são corretos, não são adequados. Por outro lado, não pode prescindir desses atributos que, nesse caso, têm o escopo de persuadir. 
Em VI, 8 [39] 13, no início do capítulo, Plotino informa da necessidade de persuadir seu interlocutor, o qual, pouco antes, havia declarado que sua alma não está absolutamente persuadida (oudén ti peistheîsa) pelo que foi dito acerca do Um, encontrando-se na incerteza (áporos - VI, 8 [39] 12, 2-3.) $)^{7}$. Plotino então assinala o elo entre a persuasão e a licença discursiva que vai levar a cabo: se é necessário, diz ele, introduzir nomes para designar aquilo que é procurado, digamos ainda uma vez que algumas coisas não foram ditas corretamente (ouk orthôs), pois não se deve fazer do Um uma dualidade nem sequer no pensamento (epinoian). Mas a fim de persuadir (tês peithoûs khárin), outras coisas agora devem ser entendidas obliquamente, isto é, imprecisamente, sem rigor, em nossos discursos (ti paranoètéon en toîs lógois - VI, 8 [39] 13, 1-5). De fato, impende observar que a persuasão é um tipo de discurso dirigido à alma, em contraste com os argumentos de necessidade: "A necessidade, efe-

7. Ao propor o uso metafórico de termos da ética e da psicologia (liberdade e vontade) para o Um, este tratado mergulha o leitor no cerne da problemática da linguagem e da dupla interrogação sobre suas potências e seus limites. Os primeiros capítulos do tratado manifestam um perfeito rigor no que tange ao discurso sobre o Um. Dominam, assim, os enunciados negativos, e Plotino dá provas de uma ascese no uso da linguagem. Em certo momento, tido como o mais negativo de todo o tratado, Plotino rejeita a simples predicação "ele é" (capítulo 8, linha 7). Logo após, multiplicam-se as determinações positivas para o Um. Haveria incoerência entre as duas partes do tratado? Lavaud sugere que é necessário considerar a presença do interlocutor que declara não estar persuadido dos argumentos até então avançados, para compreender a passagem de um modo de discurso ao outro (LAVAUD, in: PLOTIN, 2007, 175-186). 
tivamente, está no Intelecto (hè mèn anánkè en nôi), a persuasão na Alma (hē dè peithố en psykhēi - V, 3 [49] 6, 10)" . Quer dizer, os argumentos que são demonstrados por necessidade estão no plano do Intelecto, mas se ainda não foi atingido tal nível, faz-se necessário avançar argumentos situados na esfera da Alma. Portanto, há vezes em que não é possível escapar aos argumentos persuasivos. Desse modo, argumentos que se movem da imagem que está na alma em direção ao arquétipo inteligível, são da ordem do provável e não da necessidade (HEISER, 1990, 64). Todavia, nas Enéadas é claro que um argumento provável tem menos força que o necessário, pois o argumento necessário decorre de um encadeamento, não somente lógico, mas também ontológico que lhe fornece a prova'. Finalmente, cabe observar que os predicados positivos atribuídos ao Um têm o intuito de conduzir o ouvinte a pensar de modo mais convincente a pura unidade que, não obstante, é o princípio de todas as formas de dualidade. Isso porque Plotino parece considerar que a potência cognitiva e expressiva da alma humana pre-

8. "Em 6, 8-18 e 22 Plotino faz uma observação de método que diz respeito ao grau de intensidade do conhecer, pondo em confronto a certeza imediata, uma ideia que é por si mesma evidente sem limitação e com lógica necessidade, e uma compreensão da mesma realidade da qual a certeza é adquirida somente mediante argumentos adicionados e mediante uma 'retórica' argumentativa. Plotino chama estas duas diversas formas de evidência anánkè e peithô" (BEIRWALTES, 1995b, 229, grifo do autor).

9. Esta dupla de conceitos, "provável" e "necessário", ocorre três vezes no corpus plotiniano: V, 1 [10] 9, 9-11; VI, 5 [23] 8, 1-6 e V, 3 [49] 6, 40-42. 
cisa ser instruída com argumentos ricos em aspectos (BEIRWALTES, 1995 b, 231).

É importante ainda voltar à expressão ti paranoètéon que, com efeito, parece indicar mais que uma imprecisão conceitual: como nota Leroux (in: Plotin, 1990, 328), ela remete a uma espécie de temeridade; pois, a partir desse passo, a partícula hoîon adquire uma importância crescente no tratado, marcando a natureza das proposiçōes metafísicas, que são sempre aproximações. Plotino, consciente dos problemas e dificuldades que podem advir da audácia que representa, nesse caso, o uso da linguagem catafática, não cessa de advertir seu interlocutor, impondo restriçōes semânticas: "É preciso nos desculpar se, falando dele <o Um>, somos forçados, para indicar nosso pensamento, a empregar palavras que, com exatidão não podemos empregar. Mas tomaremos cada uma em virtude do 'como se" (tò hô̂on - VI, 8 [39] 13, 47-50).

Nesse caso, a restrição semântica imposta por fórmulas tais como hoîon, perturbam a lógica da afirmação, proibindo a aplicação das regras da linguagem ordinária e forçando o interlocutor a recorrer a uma semântica do limite e da hipérbole, cujo significado se situa para além do discurso. De tal sorte que, no excesso dessas fórmulas Plotino deposita o rigor da linguagem henológica (LEROUX, in: PLOTIN, 1990, 77) ${ }^{10}$. Observe-se ainda que o próprio termo "um" é pura me-

10. Leroux prefere a expressão "linguagem teológica", mas no âmbito do pensamento plotiniano, parece mais apropriado substituir o termo teológico por henológico, que é formado a partir da palavra grega hén (um, também designativo de Um entendido como o primeiro princípio plotiniano) neutro de hêิs. 
táfora (BEIERWALTES, 1981, 236-247), o que significa, em última instância, que estritamente, quaisquer determinaçôes que se lhe apliquem, só podem operar por uma transferência de sentido, mas jamais em sentido próprio. Portanto, a linguagem catafática denota uma audácia especulativa, no que tange à apreensão do Um; ela conduz a um "para além de", a um plano inefável que se revela na própria inadequação da linguagem. Donde o esforço repetido em marcar essa inadequação, essa insuficiência, que nada mais é do que a possibilidade de abertura para o que a linguagem muitas vezes tenta dizer, mostrando.

\section{ARTIFÍCIOS DE REDAÇÃO E PROCEDIMENTOS RETÓRICOS}

Os tratados de Plotino apresentam "artifícios de redação que supõem um trabalho de composição literária" (HADOT, in: PLOTIN, 1987, 16). Assim, os tratados mostram basicamente dois procedimentos discursivos, os quais enfim podem englobar os demais recursos linguísticos, tais como o mito e as metáforas, entre outros. Quais são estes dois procedimentos? Émile Bréhier (1989, XXXIV), na introdução à sua edição dos tratados das Enéadas, os classifica como discussão e discurso contínuo, também designado elevação. Segundo ele, os dois procedimentos fazem parte de outro modelo literário, a diatribe.

A diatribe nada mais é que uma tese (thésis) tratada de maneira retórico-dialética, diz Hadot (1998, p. 183). Assim, percebe-se que, na tese, subsistem es- 
boços de diálogos fictícios, originados da dialética, ao passo que da retórica provêm os principais meios de persuasão e amplificação. Os temas da diatribe são os mesmos das teses. Entretanto, Hadot prefere não classificar os tratados plotinianos como diatribe, gênero que os historiadores do século XIX e o próprio Bréhier consideravam próprio à predicação moral. De fato, Hadot não subsume a um só gênero literário os dois procedimentos anteriormente incluídos na diatribe por Bréhier. Hadot denomina de dialética o primeiro procedimento, antes chamado discussão; e o segundo, cuja denominação era discurso contínuo, retórica.

Assim entendida, a dialética consiste em uma sequência de perguntas e respostas ${ }^{11}$. O problema que se está tentando resolver é apresentado sob a forma de pergunta. Responder às perguntas consiste em estabelecer as premissas necessárias para analisar a questão. Na Antiguidade, interrogar (erōtân) parece ser o mesmo que argumentar (ARISTÓTELES, Tópicos, I, 11, 104 b 29 ss); portanto, proceder por meio de perguntas e respostas e raciocinar de modo silogístico podem ser considerados praticamente procedimentos idênticos.

Nos tratados de Plotino, a dialética tem a forma de um diálogo, onde intervêm um ou mais interlocutores anônimos. Podem suceder-se várias questóes e respostas, ou uma questão pode desencadear uma resposta bastante longa, que dispensa novas perguntas.

11. Não se trata da dialética tal como exposta no tratado III, 1 [20], que é a parte mais importante da filosofia, constituindo um caminho de ascensão ao inteligível e ao Um. 
O interlocutor (ou os interlocutores) desaparece(m), tão logo o diálogo seja encerrado. De modo geral, o problema é apresentado em forma interrogativa, por exemplo: "Diremos que o bem é composto de duas coisas, a sensação e o estado sentido" (I, 4 [46] 2, 12)? $\mathrm{E}$ a resposta, mesmo que possa vir na modalidade de uma nova interrogação, apresenta uma premissa, que pode ser novamente questionada e reformulada, através do jogo de perguntas e respostas. Todavia, o diálogo nos tratados plotinianos nada tem a ver com os diálogos platônicos (BRÉHIER, in: PLOTIN, 1989, XXXI), ao menos quanto à forma. De feito, a dialética assim entendida tem parentesco com o método de ensino da filosofia, conhecido e praticado nas Escolas a partir do século I d.C., que consiste basicamente no comentário de texto.

É consabido que, a partir da primeira centúria, os cursos de filosofia consistem em explicações dos principais textos dos fundadores das Escolas. Isso vale para os platônicos, os aristotélicos, os estóicos. Nas aulas, normalmente após a exposição do texto feita pelo mestre, ou por algum aluno, os outros alunos podiam formular perguntas ${ }^{12}$. Plotino, não diferente dos seus pares, fazia uso dos mesmos métodos, ain-

12. Esta prática remonta pelo menos ao século I a.C.. Bom exemplo são as aulas de Epicteto, por volta da segunda década do século II d.C., nas quais percebe-se que primeiro o aluno fazia uma leitura comentada de um trecho de Crisipo, por exemplo, e depois o professor corrigia eventuais erros, complementava o comentário e tecia suas próprias observações (EPICTETO, Manual, 49; Dissertaçôes, I, 10, 8; I, 26, 13). Também no século II d. C., Aulo Gélio, em Noites Áticas I, 26, relata um diálogo entre si e seu professor Tauro, testemunhando o modo como eram desenvolvidas as aulas de filosofia. 
da que isso pudesse dar margem à desordem ${ }^{13}$. Ora, o texto de Plotino parece estar em consonância com as características do ensino filosófico praticado por ele, e em voga à sua época ${ }^{14}$, tanto assim que ele se declara exegeta das antigas doutrinas, maximamente daquelas do divino Platão, em diversas ocasiōes. Desse modo, as perguntas e respostas, que podem ser lidas em praticamente todos os tratados, refletem a prática escolar. Olhando a questão por outro ponto de vista, é possível descobrir, na relação hermenêutica entre o exegeta e o texto por ele explicado, a mesma situação fundamental de diálogo, entre alguém que pergunta e outro que responde, característica da dialética ${ }^{15}$. Há textos nas Enéadas que permitem ver isso claramente, como é o caso do início do tratado Sobre as virtudes, onde Ploti-

13. Plotino, desde os primórdios da atividade docente, instigava os alunos ao diálogo: "Porque pedia que os discípulos propusessem questôes, as lições eram desordenadas e também repletas de balbúrdia, conforme narrou-me Amélio" (PORFÍRIO, Vida de Plotino, 3, 35-38 - trad. Ullmann, R. A.). Porfírio conta ainda que passou três dias inquirindo acerca do modo como a alma está unida ao corpo e Plotino não se cansou de responder. Um certo Taumásio disse então que queria escutar conferências e não diálogos, ao que Plotino respondeu: "Mas se Porfírio não me fizesse perguntas, eu não teria problemas a resolver e, dessarte, não teria nada a dizer para ser escrito" (PORFÍRIO, Vida de Plotino, 13, 15-18 - trad. Ullmann, R. A.).

14. Conforme observa Hadot $(1988,169)$, todo o período que se estende do século III a.C. até ao século IV d.C., corresponde a um triunfo da dialética e da retórica como métodos de ensino da filosofia. É evidente que o uso das duas disciplinas assume formas distintas e significações variadas, mas o fenômeno não deixa de ser geral.

15. Consultar HADOT $(1998,175)$, em referência a H. G. Gadamer, Verdade e Método. 
no parece dialogar com Platão, através da assimilação de alguns excertos de textos platônicos:

- Porque os males existem aqui, e circulam necessariamente neste lugar ${ }^{16}$, e porque a alma quer fugir dos males, é preciso fugir daqui.

- Em que consiste esta fuga?

- Em tornar-se, diz ele ${ }^{17}$, semelhante a deus.

$\mathrm{E}$ isso ocorre, se nos tornamos justos e piedosos com sabedoria prática e, de modo geral, se estamos na virtude (I, 2 [19] 1, 1-5).

Nessas linhas iniciais, percebe-se que o exegeta Plotino, nas suas falas, dialoga com o texto de Platão. Por outro lado, ele tem um interlocutor anônimo, que formula a primeira pergunta do diálogo. $\mathrm{Na}$ sequência, observa-se que o diálogo passa a ser entre os dois interlocutores, um, o próprio exegeta platônico, e o outro, provavelmente um estóico ${ }^{18}$. O diálogo com o interlocutor estóico segue até ao ponto onde o exegeta toma a palavra, formulando uma hipótese absurda

16. Citação do Teeteto, 176 a-b. A imagem da fuga do mundo e do assemelhamento a deus também encontra-se na mesma passagem do Teeteto s com a qual Plotino está dialogando. Todos os grifos do excerto das Enéadas têm por escopo destacar as citaçóes de Platão.

17. Em diversos lugares, Plotino faz referência a Platão, sem mencionar seu nome. Alguns casos: I, 3 [20] 1, 7 e 5, 4; III, 3 [48] 4, 41; III, 5 [50] 9, 25-29.

18. Em I, 2 [19] 1, 5-9, o interlocutor fictício apresenta implicitamente a tese estóica de que a virtude é fundamentalmente idêntica para os deuses e para os homens, dada a sua unidade. 
através de perguntas (FERWERDA, 1965, 62-69) ${ }^{19}$, às quais ele próprio responde. A longa resposta encerra o capítulo, informando que é necessário desenvolver o raciocínio através da persuasão (peithô), sem violência (I, 2 [19] 1, 52-53) ${ }^{20}$. O que caracteriza a resposta persuasiva? Primeiro Plotino segue fazendo uso da metáfora do fogo e do calor, para demonstrar o quanto a hipótese anterior é absurda (I, 2 [19] 1, 35-40), e, com isso, pode postular, finalmente, que o divino é uma coisa, e a virtude, outra (I, 2 [19] 1, 40-42). Segue-se, pois, uma outra metáfora, a da casa: "A casa sensível não é a mesma coisa que a casa inteligível; entretanto, ela lhe é semelhante" (I, 2 [19] 1, 42-43). Ele desenvolve essa metáfora, que é muito mais adequada para explicar as virtudes, uma vez que introduz a noção de simetria, própria da arquitetura, correlacionada à de ordem. Tais noções explicam como a casa sensível participa da inteligível, e como os homens participam da virtude, tornando-se semelhantes a deus. Por conseguinte, a imagem da casa também serve para exemplificar o conceito de participação (I, 2 [19] 1, 43-52). Como notou Hoffmann $(1997,369)$, o discurso filosófico de ensino - o de Plotino - também possui uma

19. Nas linhas 31-34, Plotino indaga se o calor de um objeto quente é semelhante ao calor do fogo. Ora, é evidente que o calor do fogo e do objeto não podem ser semelhantes, pois o calor do que é aquecido é apenas um traço do calor do fogo. A metáfora do fogo é amplamente utilizada nas Enéadas.

20. Podem ver-se, a título de exemplo, outras passagens nas quais Plotino também faz uso da noção de persuasão: V, 3 [49] 6, 9-10; VI, 5 [23] 11, 5-7. 
função anagógica, na medida em que descreve a visão e fala da necessária preparação moral para tal visão. Portanto, ele deve utilizar todos os recursos da arte literária e mobilizar, em vistas do seu próprio escopo, as potencialidades da retórica, a fim de agir sobre as almas dos alunos ${ }^{21}$.

Ora, a persuasão assume a forma de um discurso contínuo, isto é, retórico. A retórica seduz o interlocutor, seja ele leitor ou ouvinte, pela clareza da forma, mas também pela emoção. Nisso é diferente da dialética, que constrange o interlocutor pela necessidade (anánkê) de aceitar uma posição que ele não admitia no início do diálogo dialético ${ }^{22}$. Entretanto, dialética e retórica possuem em comum a seguinte premissa básica: uma situação de discórdia, na qual o objetivo é convencer o oponente a mudar sua posição inicial. Se na dialética percebe-se o conflito das posições, através das perguntas e respostas, na retórica o próprio discurso pode apresentar as teses que quer combater e, a seguir, invalidá-las, de tal modo que as técnicas da retórica incluem figuras de linguagem persuasivas pela beleza ou pela emoção que suscitam. Assim é que me-

21. Eis o que diz Hoffmann $(1997,369)$ na sequência: "Encontramos aqui o projeto filosófico do Fedro, de uma retórica filosófica. A reconciliação da filosofia e da retórica, que é um fenômeno maior do pensamento da época helenística e imperial, é chamada pela finalidade espiritual do discurso filosófico de ensino, que se apaga de maneira última diante da vida" (grifo dele).

22. A oposição entre o constrangimento exercido pela argumentação e as encantaçôes da persuasão encontra-se nas Leis, X, 903b. Note-se que, nessa passagem, Platão qualifica os mitos como encantamentos, logo, elementos persuasivos. 
táforas e mitos, sendo encantadores e emocionantes, constituem-se em instrumentos de persuasão.

Alguns bons exemplos do procedimento retórico em Plotino encontram-se no tratado VI, 7 [38]. É o caso do recurso a certas figuras de estilo, tais como, por exemplo, a prosapódose (prosapódosis), que consiste em repetir uma palavra ao final de um membro da frase, ou um membro de frase no começo de um desenvolvimento: "Para aquele que percorre a terra, todos os lugares que ele atravessa são a terra, mesmo se esta terra apresenta diferenças" (VI, 7 [38] 13, 44-51). Outra figura de estilo é a concatenação (klímax - latim: gradatio, ascensus), que consiste no encadeamento de membros da frase por repetição, sendo a última palavra repetida como primeira palavra do membro seguinte: "Não é possível que as coisas que são sejam, se o Intelecto não as conduz a ato; as conduz a ato sempre (...)" (VI, 7 [38] 13, 28-29).

Além das figuras ora exemplificadas, nesse mesmo tratado ainda encontra-se um tropo recorrente nas Enéadas, a metáfora. Rein Ferwerda $(1965,5)$, no seu importante estudo sobre o significado das imagens e metáforas em Plotino, explica que, nos tratados das Enéadas, a transferência de sentido se realiza do mesmo modo que na poesia, de um objeto conhecido e do mundo sensível, para um objeto desconhecido e, em geral, superior. Trata-se de uma comparação entre objetos distintos, o que explica o uso frequente de palavras de introdução, que se opõem a uma identificação prematura do termo figurado com o objeto designado, tais como hoîon, hốsper, tis, dikkēn, phére, hốs, amēgépē, entre outros. 
De fato, no tratado VI, 7 [38], Plotino diz que as metáforas são usadas na falta de denominações convenientes. Ele menciona metáforas que se encontram recorrentemente nos tratados: "embriagado de néctar", "no festim e no banquete", "o pai sorriu" (PLATÃO, Banquete, 203 b5, Fedro, 247 a 8. HOMERO, Iliada, V, 426; XV, 47), todas em referência ao Intelecto. Estas e muitas outras expressões do mesmo gênero, diz ele ainda, são seguidamente empregadas pelos poetas. Plotino não hesita em associar metáforas platônicas e imagens provenientes dos poemas homéricos. É o caso, ainda no referido tratado, do discurso acerca da experiência unitiva: Plotino emprega a imagem do pai feliz, sorridente, extraída da Odisséia (VI, 7 [38] 36, 18; HOMERO, Odisséia, V, 393) e recorre abundantemente ao vocabulário amoroso do Banquete e do Fedro ${ }^{23}$.

Outrossim, cabe observar que não é fortuita a utilização de vocabulário erótico nos discursos retóricos. Como bem relembra Pernot (2000, 260): "Na Grécia Clássica a reflexão sobre a palavra estava ligada à reflexão sobre o amor, na Helena, de Górgias, e no Banquete e no Fedro, de Platão, em particular”. De tal modo que a aproximação entre a retórica e o amor põe a lume a semelhança fundamental entre o trajeto do orador e o

23. Por exemplo: eflúvio de beleza (VI, 7 [38] 22, 8 e Fedro, 251 b), aguilhōes de desejo (VI, 7 [38] 22, 9 e Fedro, 251 d), o calor que penetra o amante (VI, 7 [38] 22, 14 e Fedro, 251 b), as asas que crescem (VI, 7 [38] 22, 15 e Fedro, 251 b), a aparição repentina (VI, 7 [38] 34, 13; 36, 19 e Banquete, 210 e), desejos violentos (VI, 7 [38] 34, 1 e Fedro, 250d) 
do amante: um quer convencer o auditório das suas razões; o outro quer seduzir o amado. "Em ambos os casos, há conquista, doce violência. Essa aproximação sublinha, portanto, o componente erótico da persuasão" (PERNOT, 2000, 260). Mas se é certo que a retórica tem por escopo persuadir os ouvintes ou os leitores, é igualmente certo que, para Plotino, tem um valor educativo. Plotino recorre à retórica, que, aliás, parece conhecer e dominar, não enquanto orador, mas na qualidade de exegeta de antigas doutrinas, como foi visto. Por conseguinte, se ele precisa persuadir a si mesmo ${ }^{24}$, ou a seus interlocutores, é visando à verdade que subjaz a tais doutrinas.

Um outro recurso retórico que Plotino emprega é a prosopopéia (prósōpon poiein - produzir um personagem). Esta figura de pensamento faz um personagem ausente, ou um ente abstrato falar em primeira pessoa. Ou seja, constitui um tipo de narrativa veemente na qual o escritor personifica algo ou outro alguém (que pode inclusive ser um deus, ou qualquer ser que não pertença ao mundo físico). Isso provoca a sensação de uma relação direta entre o ouvinte ou leitor e o elemento personificado. Embora o uso dessa figura seja bastante reduzido nas Enéadas, não e de menor importância, como se pode notar nas duas prosopopéias encontradas nos tratados, nas quais Plotino dá voz à natureza (III, 8 [30] 4, 1-15) e ao mundo (III, 2 [47] 3 19-42).

24. Plotino declara que sua alma não está ainda convencida pelas demonstraçôes (V, 3 [49] 6, 9; VI, 4 [22] 4, 5). Em outro lugar, se interroga sobre a necessidade de reiniciar o trabalho terminado, seguindo outro método (V, 8 [31] 3, 22). 
Quanto aos mitos, são intimamente ligados às metáforas, e por vezes se confundem com elas. Porém, enquanto as metáforas são palavras emprestadas de objetos sem vida (como, por exemplo, espelho, navio, casa, cera, escultura, fogo, entre muitas outras), os mitos são figuras divinas, ou semidivinas (os heróis) que dão vida e beleza a imagens muitas vezes secas da tradição (FERWERDA, 1965, 198). Não obstante, cabe notar que o recurso à linguagem figurada dos mitos e das metáforas, além do papel pedagógico, denota também uma unidade interna. As figuras são coerentes entre si, elas se entrelaçam e se explicam umas em relação às outras e, muitas vezes, por si mesmas. Com respeito umas às outras, a sucessão das figuras esclarece, passo a passo, diversos aspectos de algo obscuro ou algo que se situa no âmbito supradiscursivo. Todavia, as figuras apenas servem de guia para a ascensão da alma humana, pois elas não promovem o esforço da alma para reencontrar sua verdadeira natureza. Em outros termos, o escopo das figuras é comunicar uma intuição filosófica, mas essa mesma intuição não vai surgir, por consequência, necessariamente no ouvinte. Ou dito ainda de outro modo, as figuras não conduzem, elas apenas indicam. Por isso o cuidado constante de Plotino em verificar as figuras umas com as outras, ou em purificar umas com as outras. Ele cuida para que as figuras não sejam tomadas literalmente, distanciando a alma, a fazendo obliterar a verdadeira pesquisa (BELAYCHE, s/d, 39-40). Assim é que no processo de verificação das imagens e metáforas, elas apontam para sua própria superação. Em outros termos, as figuras e as comparações constituem 
o recurso mais frequente, nas Enéadas, para corrigir as imperfeiçóes da linguagem, quando se refere às realidades suprasensíveis. Conforme Laurent (1993, 189),

reduzir as imagens plotinianas a serem apenas ornamentos é vão, mas reduzir o sentido de um texto às imagens é perigoso. Assim, conferir o estatuto de argumento à imagem da fonte, ou à dos raios luminosos conduziu com frequência a falar erroneamente de um emanatismo (...). Esta explicação fácil da processão agrada nossa imaginação e negligencia o estudo racional da transcendência do Um e da doutrina dos dois atos. A imagem, como o hoîon, atenua e indica, mas não propõe afirmaçōes unívocas ${ }^{25}$.

Diante de tudo o que foi dito, é possível concluir que os mitos podem inserir-se nos textos como procedimentos retóricos, que possuem uma carga afetiva importante. Eles também têm um valor metafórico, além de um valor persuasivo. Inseridos no texto, os mitos são um dos tantos recursos utilizados por Plotino na tentativa de paliar o hiato existente entre o invisível e o visível, entre o que está para além das determinaçôes da linguagem humana e a própria linguagem. Com efeito, pode-se dizer que a linguagem

25. O que Laurent chama de imagens (images) aqui designamos como figuras, mantendo, entretanto, na tradução da passagem, o termo empregado pelo autor. 
"possui um valor designativo que se enlaça com um significado ontologicamente superior, o qual se reflete em um meio que o transforma, fragmentando-o, e que assim o manifesta e oculta” (BAZÁN, 1973, 97). Com isso, pode-se agora tentar delimitar a especificidade dos discursos míticos, face aos demais discursos que objetivam falar acerca do invisível. 
(Página deixada propositadamente em branco) 
3.

\section{DISCURSOS MÍTICOS}

Dara delimitar a definiçãao de discursos míticos, foi 1 necessário antes analisar os discursos filosóficos em geral, buscando compreender diferentes procedimentos postos em obra por Plotino, com o fito de paliar o hiato entre o sensível e o inteligível. Foram vistos, portanto, um procedimento que não tem relação com o mito, a linguagem apofática, e procedimentos que têm relação com o mito, como a persuasão, a semântica do "como se", a analogia e as metáforas. Disso resulta que o mito é um procedimento retórico e figurativo. Mas teria ele alguma especificidade? Parece que sim, sendo que o primeiro aspecto a verificar é o esquema genealógico dos mitos, pois foi esse o critério distintivo entre discursos míticos e figuras míticas. Da genealogia como forma mítica, pode-se então ler o conhecido trecho do tratado III, 5 [50] no qual Plotino enuncia a função dos mitos. Essa passagem sugeriu a alguns dos estudiosos, que a ela se dedicaram, uma 
certa confusão, ou implicação, entre mito e o plano do lógos entendido como discurso. Portanto, cabe tentar rever tais interpretações e propor um modo de deslindar tal confusão. Considera-se, efetivamente, que nem todo lógos (discurso) se ocupa da temporalidade como instrumento para conduzir a alma até ao inteligível, como parece ser o caso dos discursos míticos. Essa hipótese exige que se investigue a relação entre o tempo e o mito. Notadamente, ao investigar o que é o tempo, Plotino serve-se de uma narrativa mítica do tipo genealógica, a qual não concerne aos deuses nem aos heróis épicos, mas dá voz ao próprio tempo, para que narre sua origem. Da análise dessa narrativa pode-se investigar por que a alma, para conhecer a si mesma, a sua própria vida, que é o tempo, não parte dos fenômenos físicos ligados ao devir, mas, antes, necessita forjar uma figura do tempo psíquico, que é o mito. Isso exige que se retorne à noção de imagem, explicando que ela possui dois sentidos em Plotino, um ativo - o mimético, e outro passivo - o icônico. A Alma é imagem nos dois sentidos; por conseguinte, o tempo, que é sua vida, também o é. O tempo da narrativa mítica, por sua vez, é uma representação assimétrica do tempo da alma, correspondendo à estrutura temporal do pensamento dianoético. É isso o que permite à alma inteligir o sentido dos mitos e que faz dos discursos míticos um instrumento anagógico. Mas não se deve confundir o mito, que é um procedimento discursivo, e a dialética, que embora seja um procedimento discursivo, conforme se viu no capítulo anterior, é considerada a parte mais preciosa da filosofia, perfazendo o 
caminho ascensional de modo completo, e não apenas indicando, como o mito. Embora os discursos míticos sirvam-se dos procedimentos dialéticos de divisão e síntese, eles não cumprem todo o caminho dialético.

Plotino, quando enuncia a função dos mitos, diz que eles produzem engendramentos de seres ingerados, ou seja, eles colocam em uma narrativa do tipo genealógica estruturas hierárquicas. A genealogia expressa um tipo particular de prática do lógos: o catálogo. Katálogos, de katá-légein, significa dizer as coisas de modo sucessivo e ordenado (COULOUBARITSIS, 2000, 52). A genealogia, portanto, opera através de ordenações sucessivas e, no âmago destas, por semelhanças segundo o parentesco. Burkert (2001, 43-45) notou que, para os gregos, a genealogia constitui uma forma de pensamento arcaica fundamental: nas famílias importantes, era costume nomear os antepassados por ordem e tornar o mais claras possível as relações de parentesco, mesmo quando eram complicadas. A genealogia como forma mítica aparece pela primeira vez em Hesíodo. Ao narrar geraçóes e nascimentos na sua Teogonia, ele liga uma coisa a outra, colocando em seu lugar cada figura mítica. E, ao nomear o pai e a mãe, ele determina a categoria, o lugar e o ser. Nomeando esposa e filhos, amplia-se o sistema. Além disso, ele põe em ordem a variedade de histórias tradicionais. Cabe também assinalar que o alcance do esquema genealógico é ainda maior, quando forças "abstratas" são representadas como procriadoras, tais como, por exemplo, as Horas, a Noite, a Luta, 
o Escuro. Aqui o mito parece passar sem quebra para o lógos, conclui Burkert.

Passando da Teogonia para Os Trabalhos e os dias, percebe-se, no mito das raças, uma estrutura, senão genealógica, genética. Ambas, no entanto, aparentamse sob certos aspectos. Vernant analisou tal estrutura e observou que a gênese do mundo narrada pelas Musas, tanto na Teogonia, como no mito das raças, comporta um antes e um depois, mas isso não ocorre em um tempo único, em uma duração homogênea. Portanto, não há uma cronologia, mas genealogias. "Cada geração, cada raça, génos, tem o seu próprio tempo, a sua idade, cuja duração, fluxo e mesmo a orientação podem diferir totalmente" (VERNANT, 2002, 65). Logo, seguindo ainda Vernant, cada raça possui uma temporalidade própria, que exprime sua natureza, assim como seu modo de vida, suas atividades e características; tais elementos definem seu status e a contrapóem às demais raças. Por isso, a sucessão das raças no tempo representa valores acronológicos, reproduzindo uma ordem hierárquica permanente no universo.

Nisso a função do mito enunciada por Plotino aproxima-se da estrutura do mito em Hesíodo. Voltando às considerações de Couloubaritsis, acerca da genealogia como prática catalógica, ele nota que o mito integra a narrativa, identificando-se com uma forma de lógos. A genealogia, que absorve essa confusão entre mito e lógos, traduz o desmembramento do real e sua sequencialização, a fim de instruir acerca de suas configurações significativas. Essa operação discursiva seria elíptica, se não houvesse um redire- 
cionamento, pelo pensamento, das partes sucessivas, com o escopo de reconstruir o conjunto ${ }^{1}$.

Feitas essas primeiras considerações acerca da genealogia como forma mítica, cabe agora analisar a referida passagem de Plotino onde é enunciada a função do mito, tentando compreender as implicações entre mito e lógos, entre tempo e mito, entre dialética e mito, e assim, finalmente, estabelecer as bases para compreender mais especificamente os discursos míticos nas Enéadas.

\section{O MITO E O TEMPO}

Plotino enuncia a função dos mitos, no final do tratado Sobre o amor. É nessa passagem que se estabelece a relação entre mito, lógos e tempo.

Entretanto, os mitos, se hão de ser mitos, devem fragmentar em vários tempos (khrónois) as coisas que contam e decompor (diaireîn) a multiplicidade de seres em elementos distintos que, embora estejam juntos, separamse por classe ou por suas potências, uma vez que os discursos (hoi lógoi) também fabricam gerações de coisas ingeradas, separam mesmo coisas que são juntas e, após ensinar como podem, permitem a quem já os compreen-

1. Além do estudo já mencionado, este tema pode ser consultado também em COULOUBARITSIS, 1986; 1990a, 83-96; 2006, 249-266; 2005. 
deu (tô noèsánti) recompô-los (synaireîn - III, 5 [50] 9, 24-29 - trad. Baracat Jr.).

Este trecho "apenas registra a natureza discursiva do mito como narrativa, e a opõe ao caráter supratemporal da processão das hipóstases”, diz Pépin (1962, 55). Parece, entretanto, que não se trata apenas disso. Como nota Lacrosse $(2003,265)$, nessa definição, Plotino vislumbra os mitos, sobretudo, na sua dimensão genealógica, "a qual manifesta a relação íntima entre mito e temporalidade e põe em jogo, não somente o tempo do discurso mítico, mas também a experiência universal do tempo, que constitui a filiação e a sucessão de gerações, segundo a semelhança que ela implica”. Portanto, o que está em questão é a relação entre o tempo e os discursos míticos genealógicos, que afinal parece definir uma especificidade significativa desse tipo de discurso nas Enéadas. Esta é, enfim, uma hipótese proposta no presente estudo.

Mas esse não é um ponto pacífico entre os estudiosos de Plotino, pois, conforme o próprio Lacrosse (2003, 266), é preciso notar que apresentar como sendo temporais, através de relações genealógicas, relações inteligíveis, parece ser próprio da linguagem filosófica em geral. Isso transparece em metáforas que aludem a essa temporalidade genealógica, tais como produzir (poieîn), engendrar, nascer, gerar, ou ainda pai, designando o Um, ou mãe, tanto para o Intelecto como para a matéria. Todavia, não parecem necessariamente expressar o tempo psíquico, como aqui se considera ser o caso do mito. Tal hipótese é basilar para essa pes- 
quisa e por isso, antes de mais nada, torna-se preciso tentar desfazer a confusão entre mito e lógos, explicando o sentido do termo lógos na passagem em questão.

\section{O LÓGOS DIANOÉTICO E OS DISCURSOS SENSÍVEIS}

Os estudiosos de Plotino que se ocuparam do tratado III, 5 [50], ou da questão dos mitos, normalmente traduzem hoi lógoi por discursos. Mas, em certos casos, eles induzem a uma confusão entre a função dos mitos e a linguagem filosófica de Plotino em geral. Assim, Hadot julga haver uma certa "conivência" ou "estreito parentesco" entre o mito e os "discursos racionais”, sua tradução para hoi lógoi Ademais, ele considera que, já na filosofia de Platão, há um parentesco entre o mito e os discursos filosóficos, exemplarmente no Timeu. E que tal elo entre mito e discursos, tratando-se agora de Plotino, "deixa entrever que há algo de mítico na construção racional e algo de racional na ficção mítica. Razão (lógos) e mito são efetivamente a expressão da temporalidade da alma que, saída da intemporalidade perfeita do Intelecto, deve desenvolver nos discursos o que estava envolvido e concentrado no Intelecto" (HADOT, in: PLOTIN, 1990, 23). Em um estudo anterior, Hadot (1982-1983, 347) nota que o percurso dialético consiste em dividir o que está unido e em reunir o que foi dividido. Assim, ele aproxima mito e dialética, concluindo que os mitos e os discursos racionais correspondem à queda da alma no tempo e no espaço. 
Lacrosse $(2003,270)$ traduz lógos por discursos, entendendo que "se trata de todos os lógoi, quer dizer, tanto dos escritos dos antigos, quanto das palavras de Platão, que implicam ambos narrativas míticas e raciocínios dialéticos". Donde ele considera que os mitos constituem um modo privilegiado da racionalidade filosófica, quando esta enseja manifestar a eternidade em um mundo submetido ao tempo. Segue-se que ele associa o tempo do narrador de mitos ao do dialético, porquanto julga que a distorção entre tempo e eternidade, nos discursos míticos, encontra seu princípio, como a dialética, na alma dianoética. Por conseguinte, ele reputa a originalidade de Plotino ao fato de ter atribuído um sentido aos mitos que pode ser qualificado de dialético, como é possível depreender do final da passagem III, 5 [50] 9, 24-29, onde Plotino diz que quem inteligiu o sentido dos mitos pode reunir o que fora dividido (LACROSSE, 2003, 270-271). Há um paralelismo de termos, sem dúvida, entre este procedimento e a dialética, que opera por divisão e síntese. Cabe, entretanto, investigar se tal paralelismo realmente significa que o mito possa ser qualificado como dialético, o que será feito mais à frente.

Wolters (1972, n. 9.24-29 e 98, n. 9.27, 97), por seu turno, traduz hoi lógoi por "reasoned discourses", em oposição a toùs mýthous. Ora, Wolters não desenvolve, no comentário à linha 27 , esse tema, deixando pairar uma certa ambiguidade. Todavia, ele considera que Plotino esteja descrevendo as limitaçōes de toda a linguagem metafísica, incluindo a sua própria. Wolters nota que é um erro comum considerar a distinção tem- 
poral como sendo um traço característico dos mitos em Plotino; ele entende que Plotino diz explicitamente que isso pode ser aplicado a todos os lógoi isto é, discursos filosóficos. Por sua vez, Collette $(2002,78)$ julga não haver simetria possível entre os discursos racionais e o mito, uma vez que não se situam no mesmo registro. O discurso racional é próprio da alma e o único que ela pode ter por seu caráter intermediário. $\mathrm{O}$ mito é apenas uma forma de atualização possível do discurso racional, diz o estudioso. E, com isso Collette parece, de certo modo, subordinar o mito ao discurso racional, porquanto é uma atualização deste.

Diante dessas análises controversas, é necessário que se estabeleçam algumas distinçôes. Primeiro, é preciso notar que, nas análises que tentam nivelar o mito e os discursos filosóficos, ou racionais, conforme a terminologia dos intérpretes, observa-se uma mistura de duas coisas distintas: por um lado, é evidente que todos os discursos humanos, sejam ou não filosóficos, são diacrônicos, na medida em que são uma expressão sensível do pensamento da alma, o qual é temporal. Mas isso não significa que os discursos dividam em um esquema temporal - como é exatamente o caso das genealogias - coisas ingeradas. Ou seja, em Plotino, nem todo lógos passível de ser entendido como discurso se ocupa da temporalidade como um instrumento para conduzir a alma até o inteligível, conforme parece ser o caso dos mitos genealógicos. Por certo, todo discurso está submetido a divisōes lógico-semânticas, evidentemente inscritas no esquema sucessivo da linguagem proposicional, mas a sucessão lógica não refle- 
te a sucessão cronológica de que Plotino faz uso através das genealogias míticas. Dois exemplos recorrentes nas Enéadas ilustram o fato de ser uma especificidade dos mitos, que se inserem no esquema das genealogias, fazer uso da temporalidade como instrumento para conduzir a alma até ao inteligível. O primeiro são os discursos apofáticos, tão largamente utilizados nas Enéadas para tratar do Um. O segundo, as metáforas que se encontram praticamente em todos os tratados de Plotino. Em nenhum dos dois casos, está em jogo a oposição gerado/não-gerado. Mesmo nos mitos, como adiante se terá ocasião de observar, nem sempre é o caso de dividir em genealogias aquilo que é ingerado. Com relação a Collette, ele parece ter entrevisto isso que acaba de ser dito, mas, na sua investigação, não se ocupou em mostrar a especificidade do mito em relação aos demais discursos filosóficos e à dialética. Isso propõe o presente capítulo.

\section{CONHECER O TEMPO}

No tratado Sobre a eternidade e o tempo, III, 7 [45], Plotino define o tempo a partir da sua gênese, servindo-se de uma espécie de alegoria mítica. Esta, Lacrosse (2003, 269) considera integrante do conjunto de mitos genealógicos nas Enéadas, e, portanto, emblemático deste uso dos mitos. Antes, porém, de ver o mito, é interessante tecer algumas considerações preliminares acerca da estrutura do tratado e das possibilidades de conhecer o tempo.

No primeiro capítulo do tratado Sobre a eternidade e o tempo, Plotino diz que, para conhecer o tempo, é 
preciso primeiro investigar o que é a eternidade, pois, conhecendo o paradigma, fácil será conhecer a natureza da imagem, uma vez que o tempo é imagem da eternidade. Nesta frase já se encontra uma primeira definição do tempo que de fato será analisada por Plotino no décimo primeiro capítulo do tratado, onde o filósofo expõe sua concepção do tempo (III, 7 [45] 1, 18-20)2 . Plotino, ainda no primeiro capítulo do tratado, diz que convém examinar o que os antigos filósofos disseram acerca da eternidade e do tempo (III, 7 [45] 1, 10-17). $\mathrm{O}$ intrigante naquela frase, no entanto, é que ela sugere a impossibilidade de conhecer o tempo na temporalidade física, ou seja, a partir do seu próprio fluir no mundo sensível sem a necessidade de buscar o paradigma, a eternidade. Mas será que efetivamente não se pode conhecer o tempo no tempo? A última frase do mesmo capítulo um diz que quem quer imaginar (phantastheîn) o tempo, antes de haver contemplado a eternidade, pode chegar a ela procedendo do tempo, pela reminiscência, desde que o tempo se assemelhe à eternidade. Não há dúvidas quanto ao elo inextrincável entre a eternidade e o tempo; de um lado, a partir da eternidade, pode-se conhecer o tempo, de outro, a partir do tempo, podese chegar à eternidade. Tudo indica haver uma espécie de caminho que conduz de um ao outro. Porém, resta saber se imaginar o tempo é conhecê-lo.

2. Parece que a noção de que o tempo é imagem da eternidade, que Plotino vai retomar e desenvolver, no capítulo 11 do tratado, remete ao Timeu de Platão, 37 d 5-7. 
A memória, para Plotino, consiste em reter as imagens provenientes da faculdade da imaginação ${ }^{3}$. A imaginação pode receber imagens advindas, tanto do sensível, como do inteligível. Mas Plotino afirma que se pode partir dela, procedendo do tempo; logo, tratase da recepção de imagens sensíveis. Nesse caso, como diz Trotta $(1997,113)$, a imaginação é o ato com o qual a alma humana retém, no escorrer do tempo, as imagens que a sensação produziu ou nas quais a sensação está velada. Por conseguinte, imaginar o tempo significa reter na alma a imagem do seu próprio fluir. Todavia, isso não parece ser suficiente para conhecer o tempo, pois, se fosse, Plotino não mencionaria o embaraço diante do exame mais atento do que seja o tempo ${ }^{4}$. Afinal, ao longo da vida, vão-se retendo na alma imagens do transcorrer do tempo, através das suas mais variadas manifestações sensíveis, por exemplo, a mudança da intensidade da luz, ao longo do dia, a mudança da duração dos dias, ao longo do câmbio das estaçôes, o envelhecimento marcando linhas na

3 Plotino, com efeito, possui uma teoria complexa da memória, a qual é desenvolvida nos tratados IV, 3 [27] e IV, 4 [28] e no tratado IV, 6 [41]. Não sendo o caminho a percorrer para conhecer a eternidade, não será analisado aqui.

4. "Dizendo que eternidade e tempo são diferentes entre si, uma concernindo à natureza perpétua, e o tempo, ao devir e a este universo, pensamos ter em nossas próprias almas, espontaneamente e como por intuiçốes mais densas do pensamento, uma experiência manifesta acerca deles, referindo-nos sempre a eles e evocando-os a respeito de tudo. No entanto, quando tentamos nos concentrar neles e como que deles nos aproximar, ficamos perplexos com nossos pensamentos" (III, 7 [45] 1, 1-8 - trad. Baracat Jr.). 
face, o desabrochar e o fenecer de uma flor, e assim por diante. Contudo, dizer o que é o tempo permanece um enigma. Talvez porque o tempo só exista em sua fuga, aparecendo com a condição de desaparecer, "tanto mais obscuro como conceito, quanto mais claro como experiência. É uma evidência e um mistério: ele só se revela ocultando-se; só se entrega em sua perda; só se impóe a todos no próprio movimento pelo qual de todos escapa" (COMTE-SPONVILLE, 2000, 17).

Ao evitar este método, que vai das imagens sensíveis do tempo à eternidade, parece insinuar-se a precariedade do seu resultado, que procede de uma estreita ligação com a experiência (PIGLER, in: PLOTIN, 1999, 30). Mas o que Plotino efetivamente faz em III, 7? Primeiro trata de saber o que é a eternidade ${ }^{5}$. Então, com um conjunto de indagações, que associam o tempo à eternidade, ele sugere que estamos em contato com a eternidade, mesmo estando no tempo. Entretanto, para entender como estamos no tempo e na eternidade, é preciso saber o que é o tempo, buscando agora o tempo no tempo ${ }^{6}$. Plotino circunscreve essa busca no

5. A análise da eternidade ocupa os capítulos 3 a 6 do tratado.

6. Aqui o leitor deve notar que o texto passa para a primeira pessoa do plural, o que destoa dos demais capítulos. É que na perquirição do tempo, a primeira pessoa do plural tem uma importância fundamental em III, 7 [11], motivo pelo qual aqui se optou por trazê-la ao texto. A passagem referida é a seguinte: "Então, dizemos isso atestando coisas distintas de nós e construindo nossas reflexões como que sobre coisas alheias? Mas como? Pois que compreensão nos poderia haver de coisas com que não estamos em contato? E como poderíamos ter contato com coisas que nos são alheias? É preciso, com efeito, que nós também participemos 
tempo, de modo a tornar possível o contato da alma humana com o tempo e com a eternidade. Por isso, não se trata de estudar o tempo fenomênico, que poderia dispersar a alma com as aparências sensíveis. Mas trata-se, sim, de cotejar as teorias de alguns filósofos anteriores. No entanto, estas, ainda que sejam dignas, devem ser analisadas criticamente ${ }^{7}$ de tal modo que Plotino vai recusar, nessas doutrinas, a relação entre o tempo e o movimento dos corpos, que leva a aporias ${ }^{8}$. Em suma, Plotino quer demonstrar que o tempo não depende do movimento cósmico, mas tão-somente do movimento da Alma. Por sua vez, o mundo sensível depende do tempo, na medida em que é o produto da atividade da Alma que se chama tempo. Contudo, cabe ainda notar a tentativa de que buscar o tempo no tempo constitui apenas em aparência uma inver-

da eternidade. Mas como, se estamos no tempo? No entanto, como é possível estar no tempo e como na eternidade, nos será sabido se descobrirmos antes o que é o tempo. No entanto, como é possível estar no tempo e como na eternidade, nos será sabido, se descobrirmos antes o que é o tempo. Portanto, devemos descer da eternidade para a investigação do tempo e para o tempo: pois, lá, o caminho era para cima; mas, agora, façamos enunciados descendo, não completamente, mas do modo como desceu o tempo" (III, 7 [45] 7, 1-10 - trad. Baracat Jr.).

7. "Agora, no entanto, é preciso tomar, inicialmente, as teorias mais dignas de menção, verificando se nossa doutrina é consoante com alguma delas" (III, 7 [45] 7, 15-17 - trad. Baracat Jr.).

8. Inicialmente Plotino distingue três grupos de teorias acerca do tempo: 1 . O tempo é movimento; 2 . O tempo é coisa que está em movimento; 3 . O tempo é coisa que pertence ao movimento (III, 7 [45] 7, 17-20). A refutação ocupa os capítulos 7 a 10. Sobre o tema é esclarecedor o artigo de TROTTA (1992, 340-368). 
são do princípio segundo o qual a imagem só pode ser conhecida a partir do paradigma, o qual até então determinou para Plotino o andamento da sua pesquisa (BEIERWALTES, in: PLOTINO, 1995a, 215) e vai continuar determinando-a. Seguindo esse princípio, no capítulo 11, ao tratar da gênese do tempo e apresentar a sua definição do que ele seja, Plotino diz ser necessário voltar à eternidade. Ora, a gênese do tempo refere-se tanto à sua própria origem, quanto à possibilidade humana de gerá-lo conceitualmente:

É preciso, portanto, elevarmo-nos a nós mesmos àquela disposição que dizíamos existir na eternidade, àquela vida plácida, toda junta, já infinita, completamente indeclinável e estabelecida no Um e ao Um dirigida. $\mathrm{O}$ tempo ainda não existia, não pelo menos para aqueles <seres inteligíveis>, e nós geramos o tempo mediante o lógos e pela natureza (phýsei) do que é posterior (III, 7 [45] 11, 1-6 - trad. Baracat Jr., ligeiramente modificada).

O termo lógos da passagem em questão indica que o raciocínio humano gera conceitualmente o tempo?? $\mathrm{O}$ uso da primeira pessoa do plural acaso não remete ao "nosso" raciocínio humano? Começando por lógos,

9. Esta parece ser a tese em favor da qual advoga Beierwaltes (1995a, 238). Ademais, Sleeman e Pollet (col. 602, lógos b), referindo-se à mesma passagem, entendem o termo lógos como razão em geral, pensamento racional, raciocínio. 
face à polissemia do termo nas Enéadas, cabe indagar acerca desse nível do lógos. Ora, conforme já foi visto no primeiro capítulo deste estudo, no plano da Alma, os lógoi afiguram-se de modo discursivo, em um raciocínio. $\mathrm{Na}$ linguagem humana, articulam-se no esquema das frases e de discursos. Este lógos proferido (lógos prophorikós) é, segundo Plotino, uma imagem do lógos que está na Alma (lógou toû en psykhêi - V, 1 [10] 3, 7-8). Entendendo-se que a palavra (o lógos proferido) se manifesta como ato do lógos na Alma, esboça-se uma relação possível entre os dois sentidos do termo lógos. Mas surge uma outra questão: Plotino usa dois grupos de termos para discutir as operaçôes racionais da alma humana; é então correto tomar diánoia e logismós ou lógos, tò dianoètikón e tò logizómenon ou logistikón referindo aos mesmos processos e às mesmas faculdades? Embora Blumenthal (1971, 102 ss. $)^{10}$ julgue que em Plotino esses termos são sinônimos, de maneira mais precisa, pode-se considerar "que a faculdade dianoética seja fundadora do próprio processo de raciocínio, cuja etimologia atribuída por Plotino, a saber, dià nô̂, já ilustra seu parentesco com o Intelecto" (COULOUBARITSIS, 1992, 232) ${ }^{11}$. Mas, na passagem em questão, cabe notar que o termo lógos constitui uma unidade de sentido com phýsis, e pode ser interpretado também como "estrutura ontológi-

10. Há divergência entre os intérpretes: Blumenthal e vários comentadores consideram que são equivalentes e sinônimos. Menos numerosos são os que tendem a mostrar que se trata de faculdades diferentes. Acerca do debate, pode-se consultar COLLETTE (2002, 41 ss.), que descreve a posição adotada por cada um dos grupos.

11. De acordo com essa posição encontram-se SCHWYZER (1960, 343-378); LACROSSE (1994, 83-85). 
ca" ou "força ordenadora" própria de um ente. Resta ainda mencionar que o termo "posterior" parece ser o critério que constitui o ser do próprio tempo. Donde, logra-se compreender que "podemos gerar o tempo no pensamento somente porque a estrutura ontológica e a natureza do 'posterior' determinam nosso ser" (BEIERWALTES, 1995a, 238-239). Em outros termos, gerar o tempo pelo lógos, na alma humana, só é possível graças à estrutura ontológica da Alma, que é sucessiva. O pronome reto nós, na frase "nós geramos o tempo...”, também parece significar que quem gera o tempo é o nosso modo próprio de pensar. Com efeito, o pensamento discursivo, voltado para a multiplicidade e a exterioridade do objeto de pensamento, é sucessivo. Ademais, sendo o tempo vida da Alma, e sendo as almas individuais semelhantes à alma do mundo, e todas uma Alma, o tempo está em nós, afirma Plotino (III, 7 [45] 13, 66-68). Logo, o pensamento discursivo, próprio da Alma, há de ser algo temporal. Nesse sentido, o pensamento discursivo da alma tem seu fundamento na distensão que caracteriza o tempo, assim como o pensamento intuitivo do Intelecto tem seu fundamento na unidade do eterno, que é completa e sem partes. E por isso, quando "nós" geramos o tempo "mediante o lógos e pela natureza do que é posterior", o estamos gerando discursivamente, a partir da temporalidade própria do pensamento discursivo. Assim, parece que afinal estamos gerando o tempo no tempo. No entanto, é justamente a partir do tempo psíquico que se torna possível chegar à eternidade. Cabe agora ver como Plotino gera tal tempo, servindo-se de um discurso mítico, na sequência da passagem. 


\section{O MITO DO TEMPO}

O discurso mítico do tempo começa assim:

Porque aqueles <seres> estavam em quietude em si mesmos, talvez não se pudesse invocar as Musas, que então ainda não existiam, para narrar como o tempo se desprendeu (exépese) pela primeira vez; mas, mesmo que então as Musas existissem, talvez fosse possível perguntar ao próprio tempo que se originou como ele apareceu e nasceu (III, 7 [45] 11, 6-12).

A primeira observação que se pode fazer é que o tempo repousava no ser, isto é, no inteligível, o que implica a seguinte conclusão: o tempo procede da eternidade. Portanto, não se trata exatamente de um cair, tradução possível para o verbo ekpiptein ${ }^{12}$, mas, sim, de uma gênese necessária, que faz do tempo uma realidade na ordem processional (PIGLER, in: PLOTIN, 1999, 49 $)^{13}$, como também são realidades o lógos, em todos os seus níveis, e o amor, conforme será visto. Mas, para além disso, o verbo ekpíptein

12. Que aqui, como observa Trotta $(1997,251)$, ocupa uma área semântica mais ampla que a da culpa ética, denotada pela noçáo de queda.

13. Guitton (1959, 59 ss.) e Beierwaltes (1995a, 241), embora usem o termo "queda" para traduzir exépese, e reconheçam um certo tom negativo na passagem, admitem, por outro lado, que não se trata de uma condição de pecado do tipo gnóstico, mas sim de uma diminuição de ser, por assim dizer. Nesse sentido, Guitton chega a substituir a noção de queda por outra, de iluminação. 
permite outra abordagem, demarcando o contexto mítico da passagem.

Caso as Musas pudessem ser evocadas, elas contariam "como o tempo se desprendeu pela primeira vez" (hópōs dè prôton exépese khrónos). Essa oração parece ser uma alusão a Homero, a Ilíada P 113 (hópōs dè prôton pûr émpese... como o primeiro fogo ateouse às naus aquéias), cujo verso anterior é justamente uma evocação às Musas: "Dizei-me, agora, Musas da morada olímpica" ${ }^{14}$. Ora, na Ilíada, essa frase marca um momento difícil, no qual Heitor provoca um incêndio nas naus aquéias, o que provoca uma mudança de rumo na batalha. Em Plotino, é o tempo que se lança, e, nesse ato, a Alma se atualiza, o que provoca uma mudança no cerne do inteligível. Mas, se, na Ilíada, a expressão marca um momento difícil da narrativa, aqui, também, há uma dificuldade a ser enfrentada através do próprio discurso da gênese do tempo: ascender à eternidade para conhecer o tempo. E o que pode parecer, à primeira vista, um mero artifício literário indica a chegada de um ponto importante do raciocínio (FERWERDA, 1990, 207). Por outro lado, a referência a Homero sugere que as Musas, se pudessem ser evocadas, contariam de modo poético a gênese do tempo. Não é demais lembrar que, na tra-

14. Sobre essa citação de Homero, ver CILENTO $(1960,283) . \mathrm{Na}$ língua lusa, prefiro dizer que as Musas são evocadas, isto é, chamadas, lembradas. Invocar tem o sentido de chamar em auxílio uma força sobrenatural, pedir proteção, socorro. Parece-me que, dada a relação das Musas com a memória, evocar designa melhor a relação do poeta com elas. 
dição grega, são as Musas que ensinam o poeta, que sopram em seus ouvidos o canto divino. Também nesse sentido as Musas podem ser entendidas como uma espécie de guia para o inteligível pelo caminho da beleza. E este não deixa de ser um caminho para chegar à eternidade, mas isso pressupóe primeiro a existência das Musas, e, segundo, um amigo das Musas a evocálas. Quanto ao fato de que na eternidade as Musas ainda não haviam nascido, Plotino parece fazer eco à tradição poética que vem da Teogonia de Hesíodo: as Musas, sendo filhas de Zeus e Mnemósine, nascem no tempo já desbloqueado por Cronos (HESÍODO, Teogonia, v. 53-67 e 915-917). Este, todavia, não parece ser o motivo forte por que elas não são evocadas. Afinal, logo a seguir, Plotino parte da hipótese de sua existência e forja uma narrativa mítica, que não é cantada pelas Musas. A oração, "supondo que as Musas então existissem”, indica o início do mito do tempo, que deve afinal narrar sua história. Essa genealogia, finalmente, é o caminho aqui oferecido por Plotino para conduzir a alma à eternidade. Mas, uma vez que as Musas não podem falar, o que diria o tempo?

E ele diria sobre si mesmo algo assim: que antes, antes mesmo de engendrar esse antes e carecer do depois, repousava consigo mesmo no ser, não sendo tempo, pois também ele se encontrava em quietude na eternidade. Mas, como havia uma natureza agitada, que era desejosa de governar a si mesma e ser de si mesma e que escolheu 
procurar mais do que o presente, ela então se moveu, e se moveu também o tempo. E movendo-nos sempre em direção ao depois e ao posterior e ao não-idêntico, mas outro e então outro, fazendo um pouco longo nosso caminho, produzimos o tempo como imagem da eternidade (III, 7 [45] 11, 12-20 trad. Baracat Jr., modificada).

Um aspecto prévio a considerar é o sujeito do passo. Primeiro, tem-se o verbo dizer (légoi), cujo sujeito é o tempo. Depois, surge a menção a uma outra natureza que se move e move o tempo. Finalmente, nota-se a passagem para a primeira pessoa do plural, movendonos (kinoúmenoi) e produzimos (poiēsámenoi). Quem é este sujeito "nós", que produz o tempo? À primeira vista, o discurso mítico do tempo parece ser uma prosopopéia, tipo de narrativa veemente na qual o escritor personifica algo que não é propriamente pessoal. $\mathrm{O}$ uso de prosopopéias, como foi visto, não é de todo estranho ao texto plotiniano. Em III, 8 [30], 4, 1-15, encontra-se a prosopopéia da natureza ${ }^{15}$. Em III, 2 [47], 3, 19-42, acha-se a prosopopéia do mundo ${ }^{16}$. Enquanto as falas da natureza e do mundo ocorrem na primeira pessoa do singular, o que poderia de fato caracterizar uma personificação, a fala do tempo, não. Portanto, embora a narrativa do tempo venha introduzida como

15. Trata-se de um diálogo entre um interlocutor indefinido e a natureza.

16. Parece aludir ao Timeu 30d, 32d, 39e. 
uma prosopopéia - o tempo diria... - ela não é desenvolvida desse modo. Isso leva a discordar de Pigler (1996, p. 49), para quem o tempo em pessoa (grifo dela) se mostra. Uma sugestão mais consistente é a de Beierwaltes (1995a, 243): "O tempo refere-se à sua história metafísica como qualquer coisa de outro, de objetivo, para reportar a reflexão, através dos particípios kinoúmenoi e poiesámenoi, ao sujeito inicial (nós) que co-age nessa história do tempo". Então, tudo indica que o tempo não se personifica efetivamente, e sim, ressoa nas vozes deste "nós" inicial que, antes de começar a fala do tempo, propunha gerar o tempo mediante o lógos e segundo a natureza do posterior. E "nós" fazemos isso como se fosse o tempo ele próprio quem estivesse a narrar, porque "nós", ao buscarmos o tempo na eternidade, ou seja, no seu próprio ser, não em uma aparência sensível, o encontramos em nós mesmos, como vida da nossa própria alma, na medida em que a nossa alma é parte da Alma. Com efeito, há um elo entre o tempo, que narraria sua gênese, e nós, que a narramos: este elo é a Alma, se não toda, ao menos a parte agitada que produz o tempo.

$\mathrm{Na}$ narrativa, efetivamente, o tempo conta que estava em repouso no ser, mas uma natureza agitada (polyprágmonos) se moveu, movendo também o tempo. $\mathrm{O}$ verbo polypragmoneîn nas Enéadas indica o ato de voltar-se da Alma em direção ao exterior, ao sensível (BEIERWALTES, 1995a, 244). É consabido que não é a totalidade da Alma que se volta, mas tão-somente uma parte, ou uma imagem. Imediatamente após o relato da gênese do tempo, Plotino parece explicar algo 
acerca dessa natureza agitada: "Pois, uma vez que havia uma potência inquieta (oukh hésykhos) da Alma que sempre desejava transferir o que via lá para algo outro, ela não desejava que a totalidade lhe estivesse presente num instante" (III, 7 [45] 11, 20-23 - trad. Bracat Jr., modificada). Percebe-se, portanto, que não é a Alma total que produz o tempo, mas uma potência sua, ou seja, aquela parte da Alma que se volve para o mundo sensível, e que também é designada alma do mundo ou natureza ${ }^{17}$. Ao efetuar esse movimento, o tempo surge como a atualização do desejo da Alma de transferir o que vê no inteligível para outra coisa. Porque remete a um modelo eterno, essa afirmação permite abordar a definição do tempo como imagem da eternidade ${ }^{18}$.

Todavia, é preciso ter cautela com a noção de imagem, que pode ser imperfeita para compreender o tempo, se for entendida como uma simples cópia da eternidade, marcada somente pela relação de inferioridade com o modelo. Ora, o tempo é uma realidade em si. Cabe lembrar que na filosofia de Plotino a noção polissêmica de imagem se aplica a todos os níveis ontológicos, excetuando o Um. Mas é necessário matizar ainda mais tal noção, porquanto a imagem supõe uma relação de semelhança, que decorre, tanto de uma ini-

17. Isso concorda com a interpretação de Trotta $(1997,251)$, segundo a qual a dýnamis da alma (linha 20) está em conexão com a phýsis da linha 15.

18. Alusão a Platão, Timeu, 37 d 5. Devido aos limites deste trabalho, não será possível relacionar as definições de Platão e Plotino. No entanto, sobre o assunto, pode-se consultar LASSEGUE (1982, 405-418) e PIGLER (1996). 
ciativa do princípio, o modelo, como do principiado, a imagem ${ }^{19}$. Tal relação pode ser icônica ou mimética. É icônica quando o principiado é semelhante ao seu princípio ${ }^{20}$. Nesse caso, a imagem é um efeito, um produto ou, ainda, a projeção de um modelo. Na relação mimética, a imagem é agente, isto é, ela imita seu modelo, ela quer completar a semelhança, sem a qual permaneceria indeterminada ${ }^{21}$. Assim, é mister enfatizar que, na Alma, a relação de participação das imagens nos modelos não se constitui apenas como uma projeção icônica, mas, sim, como uma relação icônico-mimética. Ou seja, o principiado (a Alma) deseja seu modelo (o Intelecto), e tal desejo é a causa da imitação, que se constitui como assimilação. Por consequência, a iniciativa da processão não pertence somente ao princípio, mas também àquilo que dele provém, que se esforça em compreender seu princípio, assimilando-se a ele. Plotino, na continuação do texto, em uma passagem onde, por sinal, figuram vários dos termos do vocabulário da imagem, tanto icônica, como mimética, explica:
A Alma imita (mimếsei) o inteligível ao pro- duzir um cosmos sensível que se move com um movimento que não é o de lá, desejando

19. É a tese desenvolvida por Pradeau (2003, 70-82), a qual em linhas muito gerais será seguida aqui.

20. Os termos que expressam tal relação, segundo Pradeau $(2003,70)$ são eikốn, eídōlon, índalma, ikhos.

21. Os termos são mímēsis, mímēma, homoíôsis, homoíōma, formas notadamente verbais. 
no entanto ser não só semelhante (homoían) ao de lá, mas também sua imagem (eikóna), e então primeiramente temporalizou a si mesma, ao produzir o tempo em vez da eternidade; depois, submeteu o cosmos à escravidão do tempo originado, porque fez todas as coisas existirem no tempo e nele circunscreveu todos os caminhos do cosmos (III, 7 [45] 11, 27-33 - trad. Baracat Jr.).

Imitar, portanto, não consiste em fazer uma cópia conforme ao modelo, mas em produzir algo diferente: não um substituto do modelo, mas um meio de se pensar nele (LASSEGUE, 1982, 415). Portanto, do ponto de vista icônico, o tempo é fruto da contemplação do Intelecto pela Alma. Do ponto de vista mimético, o tempo representa a atividade através da qual a Alma, que na sua essência permanece eterna, move-se, gerando o mundo sensível. Por isso Plotino poderá dizer, ainda, que o tempo é a vida da Alma (III, 7 [45] 11, 42), do mesmo modo que considera a eternidade vida do Intelecto.

\section{A DIALÉTICA}

Resta ainda retornar a uma questão que ficou aberta: o mito é um procedimento dialético? Qual a relação entre mito e dialética? Esta indagação concerne tanto à estrutura genealógica, que divide, quanto à exegese, que unifica o que foi dividido. Vários autores tentaram mostrar uma certa coincidência entre mito e dialética nas 
$E_{n e ́ a d a 5^{22}}$ como foi visto no início deste capítulo. Todavia, a questão se torna mais complexa, quando se indaga acerca da dialética, pois percebe-se que não se trata apenas de um procedimento discursivo anagógico, como o mito, mas, sim, de um verdadeiro caminho ascensional. Desse modo, embora se possam entrever alguns traços de tangência entre o mito e o método dialético, um não parece ser equiparável ao outro, porquanto o mito não constitui um caminho. Com o escopo de estabelecer as similitudes e as diferenças entre um e outro, cabe investigar preliminarmente o que Plotino entende por dialética.

Plotino define a dialética no tratado I, 3 [20], Sobre a dialética. A arquitetura do breve tratado I, 3 [20] é bastante simples. O tratado divide-se em seis capítulos, sendo os três primeiros uma descrição de certas teses da dialética platônica, sob a autoridade do Fedro e do Banquete, mas também da República. Nos capítulos quatro e cinco, Plotino define a dialética e, porque ela não consiste em um método de análise da linguagem, vê-se compelido a definir a lógica. Com efeito, nesses dois capítulos, Plotino trata de estabelecer a diferença entre o que ele considera a verdadeira dialética e aquilo que as Escolas filosóficas da sua época denominavam correntemente dialética, e que ele denomina lógica ${ }^{23}$.

22. Além dos já mencionados, também pode-se citar, antes deles, Bergson $(2005,31)$, no seu Curso sobre Plotino, o qual diz exatamente que "o mito coincide, em certa medida, com a dialética".

23. Como bem observa, em um valioso estudo, Leroux (1974, 180-192), estudando o processo de separação entre a lógica e a filosofia, tal como proposto por Plotino e deslindando os elementos estóicos, peripatéticos e platônicos, que constituem o plano de fundo do tratado em questão. 
Nos três capítulos iniciais, Plotino apresenta uma via metódica que conduz certos homens ao Bem e ao primeiro princípio. Ele ainda não denomina expressamente tal via pelo termo dialética, que é mencionado, no genitivo, pela primeira vez, no tratado, somente na última frase do terceiro capítulo e, no nominativo, na primeira frase do quarto capítulo. Ainda no final do terceiro capítulo, ele refere-se ao dialético (I, 3 [20] 3, 9), o que permite supor que estes três primeiros capítulos constituem um preâmbulo destinado a mostrar quais as condições propedêuticas à dialética propriamente dita $^{24}$. O ponto de partida do tratado é, com efeito, uma interrogação: "Qual técnica, qual método, qual conduta (epitédeusis) nos faz subir aonde é preciso ir?" (I, 3 [20] 1, 1-2) Com esta pergunta, Plotino introduz três características da dialética, que é simultaneamente técnica, método e conduta, conforme ele mostra ao longo do tratado. Vale observar que esta é a única ocorrência do termo epitédeusis nas Enéadas. Este termo significa prática, incluindo o sentido de prática das virtudes, mas também ocupação, conduta; corresponde a epitédeúmata, que aparece no Banquete 210 c, quando Diotima descreve a ascensão da alma em direção ao inteligível, designando, por extensão de sentido, a prática da virtude. Dessa maneira, Plotino

24. Mas cabe notar que, embora neste tratado a dialética se apresente como o caminho que conduz à unidade, tendo a beleza e o amor como preâmbulos, essa sequencia não é sempre mantida nas Enéadas, porquanto o amor parece constituir um caminho capaz de conduzir a alma à unidade, independente da dialética (OLIVEIRA, 2005, passim). 
estabelece de início um elo conceitual entre a dialética e as virtudes ${ }^{25}$. Com efeito, a dialética para ele é um método de purificação ética ou, em outros termos, a disciplina a qual a alma se impõe para ascender ao Bem (CHARRUE, in: PLOTIN, 469). Posto isso, Plotino estabelece ser preciso chegar ao Bem ou primeiro princípio (I, 3 [20] 1, 2-4).

Porém, nem todos os homens são capazes de ascender ao Bem. Plotino, portanto, apresenta aqueles que podem ascender. Ele parte de uma frase de Platão, na qual é dito que o tipo de homem capaz de elevar-se é aquele que contemplou anteriormente as realidades, ou seja, o músico, o amante, o filósofo (I, 3 [20] 1, 5 ss; PLATÃO, Fedro, 248 d). Para Plotino, nesse contexto, cada um desses tipos de homem representa um nível distinto de ascensão. Em suma, Plotino afirma que há duas etapas para a ascensão: uma, do sensível até ao inteligível, e outra, para aqueles que já chegaram ao inteligível (I, 3 [20] 1, 12 ss; PLATÃO, Banquete 210 a; República, VII, $532 \mathrm{a}-\mathrm{b})$. Alguns elementos preliminares à definição da dialética podem ser percebidos nesses capítulos. Trata-se, em primeiro lugar, de uma via ascendente. Em segundo lugar, a ascensão constitui um aperfeiçoamento nas virtudes. Nesse sentido, a dialética, por um lado, constitui uma condição de acesso ao saber e às demais virtudes. Mas, por outro lado, quem não possui as virtudes inferiores, que são virtudes exis-

25. Mas também é possível entrever, através deste termo, uma continuidade entre o tratado Sobre a dialética e o tratado anterior, tanto cronologicamente, como na edição porfiriana das Enéadas, I, 2 [19], Sobre as Virtudes. 
tentes de modo imperfeito sem a dialética, não pode tornar-se um dialético. Este é, com efeito, o tema da segunda parte do sexto capítulo (I, 3 [20] 6, 8-24).

O sexto e último capítulo do tratado, tido como sendo de difícil interpretação pelos comentadores, foi considerado, inclusive, escrito por Porfírio com o objetivo de acentuar o caráter moral de um tratado consagrado à dialética. Porfírio teria procedido dessa maneira, com o fim de incluir o tratado no grupo I, 1-9, que é constituído de tratados morais. Entretanto, o contexto ético é de suma importância para a justa apreciação do acentuado caráter platônico do desenvolvimento da dialética, de tal modo que esse texto poderia ser considerado parenético, como observa Leroux (1974, 181. Ver I, 3 [20] 1, 12 ss; PLATÃO, Banquete 210 a; República, VII, 532 a-b). Ademais, sendo a dialética um método apropriado à virtude, ela se distingue da lógica, a qual, não tendo relação com as virtudes, é vista como um exercício prévio à purificação da alma. Nesse sentido também pode ser lida a primeira parte do capítulo, que apresenta o elo entre a dialética e as outras partes da filosofia, a física e a ética, mostrando que a dialética é, dentre elas, a mais preciosa.

Nos capítulos 4 e 5, Plotino define efetivamente a dialética. Como já se disse, ele a diferencia da lógica (logikến), que trata de proposições e silogismos (I, 3 [20] 4, 19), podendo ser caracterizada como uma técnica de análise da linguagem que, versando sobre palavras, não se ocupa das formas. Tanto as proposições como as regras, Plotino considera-as movimen- 
tos da alma (tà kinếmata tês psykhês - I, 3 [20] 5, 19). Uma vez que a lógica se serve de um movimento da alma (a regra, o teorema), para versar sobre outro movimento da alma (a proposição), ela não conduz a alma ao repouso próprio do inteligível. Efetivamente, ainda que admita a lógica como algo necessário ao caminho de ascensão dialética, Plotino afirma que na unidade do inteligível e em repouso, a alma considera a lógica e a abandona (I, 3 [20] 4, 16-20). Quiçá abandone a lógica porque o critério de verdade das proposições só pode ser aferido a partir do ser. $\mathrm{Ou}$, dito de outro modo, a verdade do dizer reside no ser e, por fim, no princípio do ser. Se o ser, a essência, a forma das palavras, vem do Intelecto, justifica-se o motivo pelo qual, ao chegar à unidade inteligível, a alma aperceba-se dos limites da lógica e dos próprios limites da linguagem humana. Uma vez que o objeto da dialética não é a linguagem, mas, sim, o ser, ao encontrá-lo a dialética não pode mais ocuparse com regras de análise da linguagem. Isso significa abandonar a lógica. Assim, a dialética põe a lume as condiçôes e limites da lógica, permitindo consequentemente atingir o mais completo conhecimento da sua natureza (VERRA, 1992, 68).

Plotino define a dialética como disposição (héxis) que permite declarar, por meio dos discursos (lógoi), o que é o inteligível (I, 3 [20] 4, 2-3). Com efeito, ele considera a dialética como sendo a disposição mais preciosa (timiōtátèn héxin) que se encontra em nós, porque ela versa sobre o ser, isto é, sobre o inteligível (I, 3 [20] 5, 5-6). Assim, falar com veracidade sobre o 
ser só é possível exatamente porque a dialética é considerada um modo de saber discursivo, através do qual a alma percorre e divide o inteligível em gêneros e espécies, para por fim chegar à unidade. Isso significa que o télos da dialética é levar a alma a repousar, ainda que precariamente, na unidade.

Ora, é consabido que todo caminho ascendente, nas Enéadas, tem uma via descendente que lhe corresponde. Por conseguinte, se a dialética permite à alma atingir o Intelecto, é exatamente porque a alma recebe do Intelecto os princípios da dialética, desde que seja uma alma capaz de recebê-los. Então a alma pode pôr em obra as operaçóes dialéticas: a dialética compõe (syntíthēsi) combina (symplékei) e divide (diaireî) as formas inteligíveis, até atingir o Intelecto perfeito (I, 3 [20] 5, 1-4). Para fundamentar este ponto, Plotino passa a associar a dialética ao seu aspecto ético. A dialética é, assim, "o que há de mais puro no intelecto e na sabedoria prática (phronéseốs)” (I, 3 [20] 5, 5) ${ }^{26}$. Observando brevemente a teoria das virtudes nas Enéadas, verifica-se que a sabedoria prática (phrónēsis) possui um duplo aspecto refletindo a pertença do homem tanto ao sensível, como ao inteligível. Assim, ela é virtude para a alma e atividade pura para o Intelecto. $\mathrm{O}$ mesmo vale para a sabedoria (sophía - I, 2 [19] 6, 13-15). Dessarte, as virtudes permitem à alma separar-se do

26. Alusão ao Filebo, 58 d 6-7. O termo intelecto aqui não parece referir-se ao Intelecto-hipóstase, mas ao intelecto da alma, isto é, à parte meramente intelectiva da alma, que não está em contato com o mundo sensível, pois permanece sempre ligada ao Intelecto supremo. 
sensível, isto é, desligar-se dos afetos, e voltar-se para o inteligível, ou seja, contemplar o ser. Portanto, elas conduzem a alma humana em direção ao Intelecto, permitindo que a alma se assemelhe a ele. Finalmente, após introduzir o conceito de sabedoria prática no tratado Sobre a Dialética, Plotino afirma que, como sabedoria prática, a dialética concerne ao ser; como intelecto, concerne ao que está além do ser (I, 3 [20] 5, 7-8) ${ }^{27}$. Após vincular dialética e ética, Plotino introduz outro ponto: a dialética não é um simples instrumento para o filósofo, posto não estar restrita a regras (I, 3 [20] 5, 8-11). Ora, isso não significa que a dialética prescinda absolutamente de regras, pois, se ela versa o ser e coisas reais, aproxima-se deles com método (hodôi) possuindo ao mesmo tempo os teoremas e as realidades (I, 3 [20] 5, 12). Vale observar que o termo normalmente traduzido por método, nesta passagem, hodôi, é o dativo de hodós, cujo sentido próprio é "caminho". O dativo instrumental expressa a ideia de espaço percorrido. É possível então compreender a passagem deste modo: por um caminho metódico a dialética atinge os seres. A insistência na noção de caminho decorre de considerações feitas em I, 3 [20] 1 , onde Plotino diz que a ascensão até ao princípio é um caminho que se cumpre em duas etapas: a primeira, do sensível até ao inteligível, e a segunda, do

27. A expressão "além do ser" alude à República, 509 b9. 
inteligível até ao $\mathrm{Um}^{28}$. Resta ainda saber como opera a dialética para atingir o repouso.

Com efeito, ao apresentar o objeto da dialética, Plotino diz, inicialmente, que ela trata do Bem e do que não é o Bem; determina quantas coisas estão sob o Bem e quantas são o seu contrário. Define o eterno e o não-eterno por meio de uma ciência e não de opiniāo (I, 3 [20] 4, 6-9), ou seja, determinar as coisas e seus contrários, assim como qualificar e quantificar são procedimentos lógicos de que a dialética se utiliza para determinar seu objeto. Uma vez separado o que pertence ao sensível daquilo que pertence ao inteligível, a dialética deixa de perambular pelo sensível, fixando-se no inteligível e então limitando a ele sua atividade (I, 3 [20] 4, 9-10). É preciso advertir, no entanto, que, mesmo separando conceitualmente o inteligível do sensível, em nenhuma parte do tratado I, 3 [20], Plotino afirma que o sensível constitua objeto da dialética. A expressão "perambular pelo sensível” aqui usada remete mais especificamente a esse movimento de reconhecimento e distinção dos dois mundos, no qual, é claro, faz-se preciso determinar os limites de cada um e, portanto, ainda que sumariamente, percorrê-los. Mas tal movimento é como um prelúdio à dialética, a qual, segundo Santa Cruz (1993, 11), “é o único modo de saber que permite apreender e desen-

28. Quanto ao vocabulário que denota a ideia de "caminho", no capítulo 1, Plotino usa os substantivos anagōgé (ação de conduzir para o alto - linhas 5, 18; da mesma família anágei linha 2), poreía (trajeto, viagem - linha 12), os verbos poreúo (transportar, conduzir - linha 15), anabaínō (subir - linha 13). 
redar a complexa estrutura do inteligível e encontrar seus gêneros primeiros".

Por conseguinte, ao definir os seres, a dialética determina as semelhanças e diferenças entre eles, o lugar que ocupam dentre os gêneros e a classe, ou seja, o gênero a que pertencem. Embora o tratado I, 3 [20] não forneça quaisquer explicaçōes sobre os gêneros, pode-se considerar que Plotino está retomando os cinco gêneros supremos do Sofista: ser, movimento, repouso, mesmo e outro. Não é o caso aqui de adentrar a tese plotiniana dos gêneros, exposta em um tratado tardio, VI, 2 [43], mas tão-somente mencionar que os gêneros são considerados princípios constitutivos do Intelecto. São eles que estruturam o mundo inteligível e o revelam ao dialético. Assim sendo, a definição cumpre-se pelo método da divisão (têi diairései), a qual, segundo Plotino, consiste em separar (diákrisis) as formas até que se determine o que é (tò tí esti) cada forma e então chegar aos gêneros primeiros. A seguir, a dialética entrelaça os gêneros, percorrendo o inteligível, isto é, fazendo a síntese, e, depois, pelo caminho inverso, a análise, chega ao princípio de onde partiu, ou seja, à unidade, à imobilidade (hessykhía) do Intelecto (I, 3 [20], 4, 12-16). O termo análise aqui deve entender-se no sentido etimológico: um movimento de subida ao princípio e de liberação. É a análise que permite reunir, juntar a multiplicidade inteligivel na unidade. Eis porque a dialética permanece no repouso enquanto estiver no inteligível (COLLETTE, 2002, 83).

Em síntese, pode-se agora dizer que a dialética é uma prática que, recebendo seus princípios do Inte- 
lecto, constitui-se como um saber através do qual (diá) ascende discursivamente (lektikế) da multiplicidade inteligível até à unidade. Quando finalmente chega na unidade, em uma retração supradiscursiva, repousa. Nas palavras de Jankélévitch (in: PLOTIN, 1998, 78), a dialética tende "a reunir os conceitos esparsos nos nossos teoremas e silogismos substituindo ao laço exterior da cópula ou da akolouthía (consecução lógica) esta imanência do inteligível a si mesmo". Segundo ele, os termos lógicos gramaticalmente justapostos, "vão se fundindo e absorvendo mutuamente, esclarecendose no sistema perfeitamente diáfano que é o universo inteligível", na medida em que a dialética segue seu curso. Porém, cabe observar que esse silêncio inteligível não significa o fim da linguagem, apenas do que pode chamar-se "discursividade linguageira" ${ }^{29}$. Efetivamente, as palavras nascem com o Intelecto; por conseguinte, a retração supradiscursiva é o reencontro do fundamento da linguagem, onde ser e dizer coincidem.

Diante do que acaba de ser visto, pode-se concluir que a dialética é algo muito mais amplo que o mito, pois, mais que uma prática discursiva, ela constitui um caminho ascensional e uma conduta de purificação pelas virtudes. $\mathrm{O}$ mito, embora seja uma prática discursiva capaz de abrir a via para a eternidade, não é em nenhum momento descrito como um caminho,

29. Segundo Collette (2002, 72), esta discursivité langagière é a alteridade característica de todos os modos de expressão próprios à alma no corpo, "uma alma que deve projetar em uma quaseexterioridade o que, no Intelecto, é um todo compacto e reunido sobre si mesmo". 
nem como uma conduta, e nem mesmo como uma técnica. $\mathrm{O}$ mito também não é, em si, um método. Mas os mitos genealógicos recorrem aos procedimentos dialéticos de divisão e síntese. Nisso apenas o mito tange a dialética, sem, portanto, se identificar.

\section{O TEMPO DO MITO}

$\mathrm{O}$ mito, enquanto narrativa genealógica, divide o que não está dividido no inteligível. Por esse movimento de divisão, ele explica, no tempo, a multiplicidade eterna, sobre a qual versa a narrativa. Mas, tal narrativa deve ser interpretada; o movimento de síntese do que foi dividido corresponde a uma restituição da unidade na multiplicidade (COLLETTE, 2002, 77). Então nota-se que uma realidade eterna e unificada, mas hierarquizada segundo o nível e o poder, foi ordenada discursivamente em esquemas genealógicos. Nesse ponto, a alma se destemporaliza, mas não significa que ela encontre a calma inteligível, como ocorre na dialética. Isso porque falta uma parte do método dialético: a análise. Por conseguinte, os mitos não parecem constituir, por eles somente, um caminho ascensional, mas, antes, parte do caminho, tendo, indubitavelmente, uma função anagógica. Além disso, os mitos não se estruturam somente nos procedimentos dialéticos de divisão e síntese; esse é o caso dos mitos genealógicos. Todos os demais parecem corresponder à dupla função da imagem, constituido-se em representaçôes assimétricas da realidade, como se verá nos capítulos 6-8 deste livro. Finalmente, a noção de imagem permite retornar ao 
paralelismo entre mito e tempo: enquanto os mitos são figuras do invisível, o tempo é imagem da eternidade.

Ainda resta indagar se a oposição gerado/ingerado dos mitos genealógicos corresponde aos conceitos de tempo e eternidade, tal como se apresentam no tratado III, 7 [45]. Lacrosse $(2003,266)$ pensa que não; segundo ele, Plotino aplica a noção de ingerados aos seres que foram, são e serão sempre (aeî). A diferença é sutil, pois, como assinala Lacrosse, pode-se tratar da vida perpétua dos deuses, do mundo, ou dos corpos celestes, cuja existência não tem nem termo, nem começo, mas eles estão, de certo modo, submetidos ao tempo. Todavia, o mito também pode versar acerca da vida do Intelecto, a única que é propriamente eterna.

Mas isso não significa que os mitos, uma vez que tenham seu sentido inteligido, não possam destemporalizar a alma. Se o tempo do mito corresponde à estrutura temporal do pensamento humano, ao interpretar o mito, buscando reunir o que está separado no tempo, a alma finalmente é reconduzida a si mesma. Ou seja, a alma só vai inteligir o sentido dos mitos, se ela conseguir passar do tempo da narrativa para o próprio tempo psíquico, isto é, de uma figura do tempo, para o próprio tempo, imagem da eternidade. Assim, do tempo psíquico para a eternidade é um passo. Por isso, o mito tem uma função anagógica nas Enéadas, dirigindo-se à alma ligada ao $\operatorname{corpo}^{30}$, isto é, à alma imersa no devir. Com essas bases estabelecidas, pode-se, nos dois próximos capítulos, analisar os mitos genealógicos das Enéadas.

30. Por outro caminho, Aubry (in: PLOTIN, 2004, 332) chegou a conclusão semelhante. 
(Página deixada propositadamente em branco) 
4.

\section{DISCURSOS SOBRE AFRODITE E EROS}

tratado III, 5 [50], Sobre o amor, se apresenta
como exegese do pensamento de Platáo acerca do
amor, com uma particularidade: tem por fio condutor
a interpretação de dois discursos míticos do Banquete,
o de Pausânias e o de Sócrates e Diotima. A importân-
cia dos mitos é tal que o próprio Plotino, ao final desse
tratado, enuncia a função dos mitos. Eles dividem no
tempo, através do esquema de genealogias, realidades
intemporais, que se estruturam segundo diferenças
hierárquicas, conforme foi visto. Com efeito, Plotino
analisa distintas genealogias de Eros, reportando-as ao
esquema da processão do Um ao múltiplo, detendo-se
principalmente na relação entre o Intelecto e a Alma
considerada em suas diferentes partes. Tais genealo-
gias, no entanto, também se relacionam em um nível
horizontal, caracterizando diferentes faces da mesma
realidade. Em outros termos, nesse tratado, além da
relação entre mito e tempo, também se pode ver clara- 
mente a polivalência dos mitos em seus dois aspectos: uma mesma figura mítica pode significar diferentes realidades metafísicas, e uma mesma realidade pode ser representada por distintas figuras míticas.

A transposição filosófica das figuras míticas, no entanto, não se limita apenas à interpretação dos dois discursos do Banquete mencionados. O tratado, com efeito, inicia indagando se Eros é um deus, um daimōn ou um estado da alma (páthos) ${ }^{2}$, ou se pode

1. A palavra daimōn foi traduzida por demônio em francês, por Bouillet, Bréhier e Hadot (démon); em espanhol, por Igal (demón), em alemão, por Harder (Dämon) e em italiano por Cilento (dèmone). Armstrong traduz por spirit e, na mesma linha, MacKenna optou por Celestial Spirit ou, por vezes, apenas Celestial, mantendo sem regularidade o grego transliterado ao lado. Esta expressão não parece traduzir adequadamente o sentido do termo daímōn em grego. Tampouco o termo demônio, que nas línguas modernas carrega forte conotação cristã. Daímōn, para os gregos, é um intermediário entre deuses e homens que acompanha os homens, cada um possuindo seu daimōn pessoal. Assim, a palavra grega parece intraduzível nas línguas modernas. Por isso, opta-se, como Wolters, por manter o termo transliterado. Para marcar a vogal longa, translitera-se $\bar{o}$.

2. Segue-se aqui a tradução proposta por Hadot para o vocábulo páthos, uma vez que a expressão "estado da alma” designa, com maior precisão, o significado do termo neste contexto, haja vista que Plotino refere-se menos à paixão, isto é, ao sentimento propriamente dito, ou à emoção, do que à modificação da alma que o sentimento ou a emoção representam (HADOT, in: PLOTIN, 1990, n. 4, 97). Próxima da tradução de Hadot é a de MacKenna, por state of mind. Bouillet e Bréhier optam por passion de l'àme, sendo que o primeiro acrescenta humaine. Cilento traduz por un certo sentimento dell'anima. $\mathrm{Na}$ mesma linha Igal: um sentimento del alma, e Harder Empfindung der Seele. Mais literal parece ser a de Armstrong e de Wolters por affection. No entanto, o termo afecção em português pertence, seja ao vocabulário médico, de- 
haver um amor correspondente a cada uma dessas coisas (III, 5 [50] 1, 1-2). De imediato percebe-se o movimento exegético que guia o tratado: deus, daímōn ou estado de alma são predicados que Platão atribuiu ao amor. Como de costume, Plotino está aludindo, ao mesmo tempo, a mais de um diálogo platônico: no caso, o Banquete, onde Platão se refere ao amor como deus e como daímōn, e o Fedro, no qual Platão considera o amor um estado de $\mathrm{alma}^{3}$. $\mathrm{Na}$ exegese dos elementos platônicos, Plotino tenta conciliar diferentes diálogos e mostrar que as contradiçôes são apenas aparentes. A fim de suprimir tais contradições, ele distingue planos nos quais o amor se manifesta (HADOT, 1981-1982, 309), numa hierarquia em três níveis: o primeiro Eros corresponde a um deus, o segundo a noção de daímōn e, finalmente, o terceiro, a um determinado estado da alma humana.

De fato, Plotino hierarquiza os diferentes amores de acordo com as divisōes internas da Alma: é um deus, quando corresponde à Alma, e um daímōn, quando é amor da alma do mundo ou das almas individuais. $\mathrm{O}$ amor é estado de alma, quando provém de algo exterior à alma, ou seja, quando é acidental.

signando uma alteração patológica do corpo, seja ao vocabulário psicológico, designando uma anormalidade psíquica, ou ainda um estado de morbidez, o que não se aplica ao termo grego páthos no contexto das Enéadas.

3. Este tratado se apresenta como exegese do pensamento de Platão sobre o amor: para proceder ao exame das questōes, deve-se percorrer as especulaçōes (epinoías) dos homens, especialmente no campo da filosofia e, em particular, do divino Platão, que muito escreveu sobre o amor em muitas passagens das suas obras (III, 5 [50] 1, 4-6). 
No que tange às almas humanas, Plotino descreve três aspectos do amor acidental, no primeiro capítulo do tratado: é amor puro, quando é um desejo pela beleza; amor misto, quando, além de desejo pela beleza, também é desejo de se perpetuar. E, por fim, amor desviado, que se mantém preso à materialidade, isto é, a imagens fugazes da beleza.

A intricada exegese dos mitos de Eros e Afrodite começa apresentando algumas variantes platônicas sobre a genealogia de Eros e, dessarte, introduzindo a figura de Afrodite.
Entretanto, acerca desse Eros a quem con- sideram deus não apenas os outros homens, mas também os teólogos ${ }^{4}$ e também Platão, que em muitas passagens diz que ele é filho de Afrodite 5 e que seu ofício é o de 'supervi- sor de belos rapazes' ${ }^{6}$ e de motivador das al- mas à beleza de lá ou, ainda, o de aumentar a tendência já existente para a beleza de lá7:

4. A expressão "os teológos" reaparece em 8, 22-21 e refere-se aos autores das teogonias e cosmogonias antigas, especialmente Hesíodo. Wolters $(1972$, n. 2.2, 18) nota que theología e seus cognatos são inseparavelmente associados com mito, em implícito contraste com a filosofia.

5. PLATÃO, Fedro, $242 \mathrm{~d} 9$.

6. PLATÃO, Fedro, 265 c 2-3.

7. PLATÃO, Fedro, 251 b e 252 b: o amor dá asas à alma; Banquete, 210 e - 212 b: o amor eleva a alma cada vez mais alto rumo a beleza em si; Banquete, 210 d: na ascensão, sob o impulso do amor, a alma adquire força e cresce. 
acerca dele, sobretudo, devemos filosofar ${ }^{8}$; além disso, devemos aceitar todas as coisas ditas no Banquete, entre as quais não $<\mathrm{diz}$ que ele nasceu de Afrodite, mas que $><$ foi concebido $>$ no nascimento de Afrodite a partir de Penía e de Poros ${ }^{9}$. Mas parece que o discurso vai exigir-nos que digamos algo também sobre Afrodite, quer se diga que Eros nasceu dela, quer com ela. Primeiro, então, quem é Afrodite? Em seguida, será que Eros nasceu dela, ou com ela, ou há algum modo de ter ele nascido ao mesmo tempo dela e com ela? (III, 5 [50] 2, 1-14 trad. Baracat Jr., ligeiramente modificada).

Efetivamente Plotino não responderá a todas essas questôes no tratado; entretanto, ele vai recorrer a diversas passagens de diálogos platônicos versando sobre Eros ou sobre o tema do amor para mostrar que Afrodite é a Alma e que Eros consiste no amor que a Alma sente pelo belo e pelo Bem. Em suma, para Plotino, Eros nasce do ato contemplativo de Afrodite, sendo idêntico a este ato. Portanto, Eros é considerado filho e companheiro de Afrodite. Observe-se, porém, que aqui Plotino também introduz os teólogos, anunciando, dessarte, que não somente elementos platônicos dos mitos de Eros e Afrodite, mas também teogônicos

\footnotetext{
8. Aqui a filosofia vai tratar da figura mítica Eros mostrando seu estatuto ontológico (WOLTERS, 1972, n. 2.6, 19).

9. PLATÃO, Banquete, 203 c.
} 
e cosmogônicos entrarão em cena. Isso fica mais claro no estudo das figuras míticas. Assim, serão vistos, primeiro, os mitos de Eros e Afrodite Urânia; depois o segundo Eros e a segunda Afrodite; por fim, Eros filho de Poros e Penía.

\section{FACES DE AFRODITE}

Se Eros pode corresponder a um deus, a um daimōn, e ainda a um estado da alma, Afrodite igualmente apresenta distintas faces nas Enéadas. A polissemia dos mitos em Plotino, entretanto, não se afasta muito de uma prática comum no mundo grego, e a figura de Afrodite parece testemunhar adequadamente isso. Ao percorrer a poesia épica, encontram-se diferentes faces de Afrodite, duas das quais foram postas em um esquema hierárquico por Platão. Segundo Hesíodo, na Teogonia, 189 ss., ela descende de Urano. Em Homero, na Ilíada, Afrodite não descende de Urano, mas figura como uma deusa Olímpia, filha de Zeus e Dione $^{10}$. Essas diferentes faces de Afrodite resultaram em duas Afrodites distintas, cunhadas pela imaginação platônica no Banquete. Plotino segue a divisão estabelecida por Platão, ajustando os atributos de Afrodite às exigências da sua filosofia. Além disso, Plotino

10. "Dione é uma das deusas da primeira geração divina. A sua origem diverge consoante as tradiçōes: ora se diz que é filha de Urano e Gaia (...), ora se considera ser uma das Ocêanides, filha de Oceano e Tétis. Por vezes conta-se também entre as filhas de Atlas" (GRIMAL, 2005, 121, “Dione”). 
dá mostras de conhecer alegorias físicas dos mitos de Afrodite correntes à sua época.

Afrodite, na Teogonia, desde seu nascimento, é acompanhada de Eros (HESÍODO, Teogonia, 201). Além disso, ela aparece como deusa da procriação ${ }^{11}$ e das estratégias amorosas (HESÍODO, Teogonia, 203-206). Mas não é só isso: ela surge como elemento de doçura e beleza em oposição às potências violentas nascidas das gotas de sangue do falo decepado, que respingaram a Terra, as Erínias vingadoras de crimes entre consanguíneos, os Gigantes que personificam a violência guerreira e as Melíades, Ninfas que habitam os freixos donde provém a madeira para as lanças guerreiras (HESÍODO, Teogonia, 182-187). Afrodite desposa Ares, nascido de Zeus e Hera, com quem tem três filhos: Fobo, Deimo e Harmonia (HESÍODO, Teogonia, 934-937).

Em Homero, além de uma genealogia distinta, também se percebem outras relações de parentesco. Por exemplo, na Ilíada, Afrodite é irmã de Ares (HOMERO, Ilíada V, 370 - 430). Na Odisséia, Afrodite e Ares passam a ter ligações de outro gênero: ela é amante do deus guerreiro, embora seja casada com Hefesto $^{12}$. Além disso, Homero também nomeia de Afrodite os prazeres da união sexual (HOMERO, Odisséia, XXII, 444). A propósito, ao longo das variantes do mito, são conhecidos os episódios dos amores de

11. Desde que surgiu, por onde Afrodite pisava, relva nascia (HESÍODO, Teogonia, 194).

12. O famoso episódio em que Hefesto flagra os amores de Ares e Afrodite é narrado pelo aedo Demódoco, em HOMERO, Odisséia,VIII, 266-367. 
Afrodite por outros deuses, como Hermes e Dioniso, ou heróis, tais como Anquises e Adônis. Outrossim, as etimologias dos epítetos de Afrodite adquirem, para os escoliastas da Odisséia e da Ilíada, significados distintos dos estabelecidos nos poemas épicos. Cípria e Citeréia eram relativos a lugares, Chipre e Citera ${ }^{13}$. Cípria passa a significar "aquela que faz conceber", e como a ação se aplica também aos bichos selvagens, ela é chamada Citeréia (Scholia Venetus B à Il., V, 422). Mais tardiamente, por volta do século $\mathrm{V}$ a.C., as versóes do mito de Afrodite variam, e passam a considerá-la mãe de Eros e Himeros, além dos outros filhos que Homero lhe atribui. Quanto à paternidade, por vezes Eros é filho da sua união com Ares, outras com Hermes.

Afrodite representa, para alguns dos exegetas de Homero, o desejo desregrado, estranho à razão. E isso não somente devido aos seus amores adúlteros, mas também por ter infundido uma loucura em Helena, que fê-la entregar-se aos braços de Páris (HOMERO, Odisséia, IV, 260). Aliás, o episódio dos amores de Ares e Afrodite é uma das passagens da Odisséia que mais fez correr tinta na Antiguidade. Zoilo de Anfípolis, um orador que parece ter escrito nove livros contra Homero (BUFFIËRE, 1956, 22), fornece um bom exemplo do tipo de ataque a tal episódio. Quando os dois amantes são pegos em delito, os deuses riem forte e Hermes diz que gostaria de estar no lugar de

13. Afrodite é chamada de Citeréia, por exemplo, em HOMERO, Odisséia, VIII, 288. Também em HESÍODO, Teogonia, 198-199. 
Ares, ainda que isso implique certa vergonha ${ }^{14}$; ora, diz Zoilo, o riso dos deuses é inconveniente, e as palavras de Hermes, deslocadas. A que, tempos depois, replica um escoliasta: "Os deuses dos poetas não são os dos filósofos; eles riem” (Scholia $\theta$ in Od., 332). De fato, o sentido filosófico dos mitos não admite nem a imoralidade nem o sarcasmo dos deuses. Por sua vez, para os alegoristas, a poesia pode se servir de imagens inconvenientes, pois tanto a imoralidade quanto o sarcasmo são sinal de que há um sentido subjacente à letra do texto. Além disso, quanto mais um mito é atacado, tanto mais ele é defendido: os amores de Ares e Afrodite receberam interpretações que os transformaram em princípios cosmogônicos, elementos ou forças físicas (BUFFIËRE, 1956, 168-172 e 297-306). Plutarco é testemunha de tal tipo de interpretação, a qual ele condena:

Estes mitos, alguns comentadores, com o que eles chamavam outrora subentendido, e que chamamos agora alegorias, torturam e falseiam a interpretação. $\mathrm{O}$ adultério de Afrodite e Ares, denunciado por Hélio, significa que a conjunção dos planetas Marte e Vênus determina naqueles que nascem sob seu signo, o gosto pelo adultério, e que, se o sol, subindo no céu, os surpreende, estes adúlteros não permanecem ocultos. Quando Hera veste-se em honra a Zeus e recorre

14. Sobre o adultério de Afrodite e Ares, HOMERO, Odisséia, VIII, 266-369. 
a um cinto mágico ${ }^{15}$, querem que se trate na realidade de uma purificação do ar que se aproxima do elemento ígneo. Como se o poeta não desse ele próprio, uma explicação! (PLUTARCO, Como o jovem deve escutar os poetas, 4, Moralia, 19).

Plotino certamente conhecia tais interpretações, mas, assim como Plutarco, não parece ter concordado com elas, pelo que deixa entrever a única menção a Ares nas Enéadas:

Sustentar que determinados planetas, sendo eles Ares ou Afrodite, causam adultérios, se estiverem de determinado modo, como se com a licenciosidade dos homens preenchessem eles mesmos o que necessitam um do outro, como não é isso uma grande desrazão? (II, 3 [52] 6, 1-4 - trad. Baracat Jr.).

Dessarte, pode-se concluir que Plotino conhece distintas interpretaçóes alegóricas da figura de Afrodite e diferentes faces da figura mítica. No entanto, no tratado III, 5 [50] ele propõe uma exegese de certos atributos da figura de Afrodite, principalmente a partir do discurso de Pausânias, no Banquete. Mas, evidentemente, Plotino interpreta o mito segundo elementos da sua filosofia, transformando o significado que Pausânias confere a Afrodite: nas Enéadas ela passa

15. Sobre a vestimenta de Hera, HOMERO, Ilíada, XIV, 153-189. 
a representar a Alma em suas duas divisões internas, como será visto a seguir.

\section{DUPLA AFRODITE}

Plotino diz que Afrodite é dupla (dittến): a primeira é descendente de Urano, a segunda é filha de Zeus e Dione (III, 5 [50] 2, 15). Com efeito, aqui ele retoma a divisão estabelecida no discurso de Pausânias, no Banquete, segundo o qual Afrodite e Eros são inseparáveis; havendo duas Afrodites, há consequentemente dois Eros $^{16}$. A mais velha não tem mãe e é filha de Urano, o céu, por isso é chamada Urânia (celeste), a outra, mais jovem, é a filha de Zeus e Dione (PLATÃO, Banquete, $180 \mathrm{~d}$ ).

Pausânias, ao estabelecer essa distinção, tenta definir qual Eros deve ser elogiado (PLATÃO, Banquete, 180 d). Assim, ele parece retomar a Afrodite da Teogonia de Hesíodo para estabelecer a universalidade de Eros e Afrodite, pois, nascida do esperma de Cronos mutilado, esta Afrodite não participa do feminino; a ela atrela-se um Eros que se dirige somente aos homens (PLATÃO, Banquete, 181 c). Ora, o amor masculino, com

16. "Fazendo Pausânias destacar a Afrodite celeste da humana, o fixo e o móvel, Platão introduz o pensamento que ele próprio elaborou e que será exposto por Diotima. Ao declarar que não se pode falar de Eros sem lembrar Afrodite, Pausânias adere às versōes recentes do mito que subordinam Eros à deusa como filho ou auxiliar. Nessa deriva, Eros vai depondo as qualidades cósmicas que os antigos lhe tinham conferido para assumir feiçóes definidas e para se vulgarizar em conflitos privados no caminho da subjetivação" (SCHÜLER, 2001, 41). 
sua esterilidade física, abre a possibilidade para que a força erótica se ligue a outras coisas: o pensamento se erotiza, dirigindo toda a força erótica ao belo, que se situa acima dos corpos e das relaçôes sociais. Nada é mais belo que a virtude, por isso o Eros celeste faz com que aqueles que amam e os que são amados cuidem de si mesmos com o fito de se tornarem virtuosos (PLATÃO, Banquete, 184 b -185 c). Este Eros é digno de elogio. Todos os demais Eros concernem a Afrodite Pandêmia, a mais jovem que, sendo filha de Zeus e Dione, participa tanto do masculino, como do feminino. Portanto, os amores pandêmios dirigem-se assim a homens como a mulheres (PLATÃO, Banquete, $181 \mathrm{c}$ ). Não sendo este Eros digno de elogio, Pausânias não se detém em explicá-lo. Mas ora, a Afrodite homérica está ligada a uniôes sexuais, inclusive sob a égide do adultério e da traição ${ }^{17}$. Além disso, é sabido, por exemplo, que o templo de Afrodite, em Corinto, abrigava grande número de hetairas. Também é sabido que o casamento reproduzia nomes e riquezas. Ou seja, por um lado, tem-se uma erótica ligada ao prazer das unióes carnais, que é dado em troca de somas monetárias. Por outro, uma erótica que visa reproduzir estruturas sociais. Portanto, parece estar subentendido, no pensamento de Platão, que Eros pandêmio concerne não somente ao corpo individual, mas também à pólis.

17. Quanto à traição, refiro o episódio do enforcamento das escravas que se deitaram no leito dos pretendentes de Penélope, no qual Odisseu menciona Afrodite em alusão a tal perfídia (HOMERO, Odisséia,XXII, 444). 
Plotino acolhe as duas Afrodites e os dois Eros do discurso de Pausânias, estabelecendo, através dessa diferença de nível marcada pela genealogia, uma outra estrutura hierárquica, não à guisa de louvar um amor em detrimento do outro, e sim, com o intuito de explicar os diferentes planos da Alma: a Urânia é mais antiga e, portanto, hierarquicamente superior, representa a Alma hipostática, enquanto a outra, mais jovem, corresponde à alma do mundo e às almas humanas.

$\mathrm{O}$ esquema geral das genealogias de Eros ligado a cada uma das Afrodites, em suas relaçôes vertical e horizontal, a primeira representando os níveis hierárquicos, a segunda as correspondências internas entre figuras e realidades metafísicas, pode ser assim esboçado:

\begin{tabular}{|l|l|l|l|}
\hline Urano & - & - & Um \\
\hline Cronos & Zeus + Dione & Métis & Intelecto \\
\hline $\begin{array}{l}\text { Afrodite } \\
\text { Urânia }\end{array}$ & Afrodite daímón & Poros + Penía & $\begin{array}{l}\text { Alma/alma do } \\
\text { mundo e almas } \\
\text { particulares/lógos + } \\
\text { matéria inteligível }\end{array}$ \\
\hline Eros deus & Eros daimōn & Eros daímōn & Amor \\
\hline
\end{tabular}

Lido verticalmente o esquema, as três primeiras colunas apresentam as genealogias de Eros deus e Eros daímōn, e a quarta coluna traz as correspondentes realidades metafísicas. Lido horizontalmente percebe-se que mais de uma figura refere-se a uma mesma realidade. Essa polivalência, a bem da verdade, reflete diferentes aspectos da realidade. É, portanto, digno de nota que, nesse mito, ao Um corresponda somente uma figura, a de Urano. Por outro lado, o 
caso mais evidente de polivalência, no quadro acima, é o da Alma. Com efeito, nesse tratado a dificuldade em compreender a que nível da Alma - superior ou inferior - Plotino se refere é mitigada, em um primeiro momento, pela diferença entre Afrodite Urânia, considerada uma deusa, e a segunda Afrodite, tida por daímōn. Considerando a estrutura do real proposta nas Enéadas, é possível organizar o esquema genealógico diferentemente, desnivelando as duas Afrodites e os dois Eros, de acordo com as divisões internas da Alma. Quanto a Zeus e Dione, se eles são os genitores da alma do mundo, talvez devessem ser postos no nível da Alma, ou ainda, Zeus no mesmo nível de Cronos, representando o Intelecto, o que estaria de acordo com a interpretação da figura de Zeus nos três capítulos finais do tratado, e Dione, sobre quem Plotino nada fala, no nível da Alma. Tal divisão obedeceria ainda a um princípio exegético também apresentado ao final do tratado, de que os deuses correspondem ao Intelecto e as deusas à Alma.

Então, para a primeira parte do tratado, que se ocupa de Afrodite e Eros, tem-se:

\begin{tabular}{|l|l|l|}
\hline Urano & - & Um \\
\hline Cronos & Zeus & Intelecto \\
\hline $\begin{array}{l}\text { Afrodite } \\
\text { Urânia }\end{array}$ & Dione & Alma (parte superior) \\
\hline & Afrodite daimōn & alma (parte inferior) \\
\hline Eros deus & Eros daimōn & $\begin{array}{l}\text { Amor da Alma alma inferior e das almas } \\
\text { humanas }\end{array}$ \\
\hline
\end{tabular}


Aqui novamente a leitura vertical apresenta, nas duas primeiras colunas, as genealogias de Eros deus e Eros daimōn. $\mathrm{Na}$ terceira coluna, tem-se a hierarquia das realidades superiores, agora mostrando a divisão interna da Alma e o amor correspondente a cada uma das partes. Cabe, agora, ver em detalhe as figuras de Afrodite e Eros, começando por Urânia.

\section{A PRIMEIRA AFRODITE}

Se Pausânias, no Banquete, respeita a genealogia hesiódica de Afrodite, Plotino, por sua vez, estabelece uma espécie de "correção": Afrodite Urânia nasceu de Cronos (III, 5 [50] 2, 19), que por sua vez é filho de Urano. A imprecisão, descendente de Urano e de Cronos, não é fortuita (LACROSSE, 1994, 44), pois Urano e Cronos designam, respectivamente, o Um e o Intelecto; por conseguinte, quando a Alma olha em direção a Cronos, o Intelecto, através deste, vê Urano, o Um. Por outro lado, como já foi visto, o nascimento de Afrodite, na Teogonia, é consequência de um gesto certeiro de Cronos: portanto, ela descende da espuma do esperma de Urano, mas sua vinda à existência depende de um movimento intermediário, executado por Cronos. Ainda que Plotino não mencione esse episódio, de certo modo ele corresponde à ambiguidade que se encontra em III, 5 [50], pois a Alma tem por princípio primeiro o Um, mas ela é produzida pelo movimento do Intelecto em direção ao Um. Nesse caso, o Intelecto é um intermediário entre a Alma e o Um. 
Plotino precisa: Afrodite é descendente de Urano, donde seu nome ${ }^{18}$. Porém, chamá-la Urânia parece ser um modo de reiterar a pertença ao céu (urano), metáfora do inteligível ${ }^{19}$, o que manteria a ambiguidade. Sendo esta a conotação do epônimo Urânia, o que significa ser filha de Cronos?

E é necessário que a Afrodite chamada urânia, por ser nascida de Cronos, que é o Intelecto, filho daquele, seja a alma mais divina que, nascida imediatamente dele, que é puro, pura (akēraton akērátou) lá em cima, não querendo nem podendo vir para baixo, pois não nasceu para andar entre as coisas aqui em baixo, por ser uma realidade (hypóstasin) separada e uma essência (ousían) impartícipe da matéria (amétokhon hýlēs) - daí terem dito enigmaticamente (einittonto) que ela é 'sem mãe' (amétora) -, e com muita justiça pode-se chamá-la deusa, e não daímōn, uma vez que não é misturada (katharán) e permanece pura em si mesma (III, 5 [50] 2, 19-27 - trad. Baracat Jr.).

$\mathrm{O}$ início desta passagem tem por pano de fundo a etimologia do nome de Cronos no Crátilo, 396 b: Cronos, "kóros significa, não uma criança, mas a pu-

18. Em III, 5 [50] 2, 15, Plotino utiliza o mesmo genitivo que se encontra no Banquete 180 d 4, ouranôे.

19. "No mundo inteligível tudo é céu" (V, 8 [31] 3, 31). 
reza sem mistura do seu intelecto" (trad. Figueiredo). Neste passo, há um jogo entre Cronos e kóros, nitidez, saciedade. Os epítetos puro e sem mistura, que definem Cronos, no Crátilo, são aplicados por Plotino a Afrodite, sugerindo que ela descende de Cronos e herda suas qualidades. Mas não é somente a Platão que se refere Plotino. O imperfeito plural einittonto pode ser indício que "sem mãe" provém de Platão e dos antigos teólogos: tanto em Hesíodo (Teogonia, 188-196) como em Platão (Banquete, 180 d), Afrodite Urânia não tem mãe. Evidentemente, esse dito enigmático exige uma hermenêutica. Sem mãe, no contexto das Enéadas, significa sem participação na matéria sensível ${ }^{20}$. Isso faz de Afrodite um inteligível puro, porquanto na lógica das Enéadas a participação na matéria sensível estabelece a separação entre inteligível e sensível. Há um princípio admitido ao longo de todo o tratado, segundo o qual o divino é aquilo que não tem mistura (III, 5 [50] 6, 39-45). Porque se mantém pura, ou seja, separada radicalmente do mundo sensível, Afrodite é uma deusa, é uma realidade e uma essência. Mais adiante Plotino dirá que a Alma, representada por Afrodite Urânia, é "somente Alma”, "absolutamente Alma” (III, 5 [50] 3, 31), ou seja, não é alma de algo, o que significa que não está em relação

20. Vale observar que "mãe" é uma metáfora para designar a matéria, que é "mãe de todas as coisas" (III, 6 [26] 19, 1). Tal metáfora provavelmente se fundamenta na identificação entre matéria e mãe no Timeu 50 d 3 e 51 a 4-5. Nesse passo do tratado III, 5 [50], parece que se trata da matéria do sensível, porquanto a matéria do inteligível está presente no Intelecto e na Alma. 
com outra coisa. Nesse sentido, também pode-se entender que a Alma seja uma realidade essencial.

Por fim, em alusão possivelmente a uma outra etimologia do Crátilo, 396 c 1, horōsa tà ánō, o epônimo Urânia designa também a contemplação do mundo superior, pois tal contemplação vê o que está no alto - horôn kaì autòs ánō (III, 5 [50] 3, 20). Plotino retoma a genealogia Cronos/Urano, mas agora para explicar que a Alma permanece no inteligível. Tal como provém de Cronos, Afrodite se mantém "seguindo (ephepoménè) Cronos ou, se quisermos, o pai de Cronos, Urano" (III, 5 [50] 2, 32-34). É interessante observar que, de uso raro no grego tardio, o verbo ephépō significa, além de seguir, também alcançar, suspender, praticar e estar de acordo. Esses sentidos concernem ao ato contemplativo de Afrodite: ao olhar Cronos e através dele Urano, ela se mantém suspensa no mundo inteligível, permanecendo em acordo com ele, na medida em que não se mistura ao sensível. $\mathrm{O}$ uso deste verbo, por conseguinte, parece reforçar a ideia de que a Alma permanece no alto, pois não quer, nem pode andar cá embaixo. De fato, o Intelecto exerce uma força de atração sobre a Alma, comparável com a do sol sobre a auréola luminosa; todavia, o Intelecto mantém a Alma ligada a ele bem mais que o sol mantém presa a luz que refulge dele (III, 5 [50] 2, 27-32) ${ }^{21}$. Com efeito, essa metáfora não somente acentua a ligação da Alma com o Intelecto, como ainda insiste sobre o fato

21. Nestas linhas Plotino está revisando teses sobre o Intelecto manter a Alma presa a ele. 
de que ela tem nele sua fonte. Enfim, ao seguir Cronos e, através dele, Urano, Afrodite concentra sua atividade em Cronos, tornando-se plena de amor (erastheîsa) por ele (III, 5 [50] 2, 32-34). Nesse ato, gera Eros.

\section{O PRIMEIRO EROS: DEUS}

Assim como Afrodite, Eros da Alma urânia permanece olhando em direção ao alto, na medida em que é seu companheiro, e que é engendrado a partir dela e por ela. Plotino tenta resolver uma divergência entre duas passagens de diálogos platônicos, Fedro 242 d, onde Eros é filho de Afrodite, e Banquete, 203 c, no qual ele é companheiro da deusa, fazendo de Eros o olhar amoroso de Afrodite em direção a Cronos:

(...) Amando-o, engendra Eros e com este olha para aquele, e esse ato da Alma produz uma realidade e uma essência, e ambos olham para lá: a Alma que engendra e o belo Eros engendrado como uma realidade que está eternamente voltada para outro ser belo e que nisso fundamenta seu ser, sendo um intermediário assim como o olho do desejante é intermediário entre o desejante e o desejado, porque fornece ao amante a visão do amado por sua mediação, mas ele próprio o precede, plenificando-se com o espetáculo antes de fornecer ao amante a possibilidade de ver mediante o órgão, vendo, antes, é verdade, mas não do mesmo modo, porque, 
apesar de fixar no amante o objeto da visão, ele mesmo desfruta de uma beleza que passa correndo por ele (III, 5 [50] 2, 35-46 trad. Baracat Jr.).

A beleza de Eros - ho kalòs Érōs - remete a Eros primevo, o mais belo entre os deuses imortais, na fala de Hesíodo (Teogonia, 120); portanto a beleza situa Eros na grei dos grandes deuses, marcando sua superioridade e dignidade. A beleza também é atribuída a Eros por praticamente todos os discursos do Banquete, salvo o de Sócrates e Diotima, que faz de Eros um intermediário à procura da beleza, um daimōn capaz de, perseguindo a beleza em diferentes níveis, elevar a alma ao mundo suprasensível, como será visto. Notese que Eros neste passo das Enéadas também é considerado intermediário (metazý), mas não por ser um daimōn. Efetivamente, o que aqui define a noção de intermediário é a metáfora do olho ${ }^{22}$, a qual descreve a função do amor tendo por referência a visão sensível. Segundo Plotino, o amor é um intermediário entre a Alma e o Intelecto, como o olho do amante é um intermediário entre o amante e o amado. É o olho que permite ao amante ver o amado, na medida em que se enche do espetáculo visível da beleza, antes de

22. Hadot (in: PLOTIN, 1990, 62-63) observa que Eros, como olho de Afrodite, é uma metáfora inesperada, quiçá mesmo única na história da literatura e das artes antigas, ainda que o tema do parentesco entre o amor e o olho seja muito frequente. Ele sugere que esta metáfora seja uma alusão ao deus egípcio Horus, que Plutarco identifica com Eros, e do qual o olho é um conhecido símbolo cultual. 
proporcioná-lo ao amante. Porém, o olho não retém o espetáculo, de tal sorte que só desfruta fugazmente da beleza (III, 5 [50] 2, 40-45). Em suma, o olho é um lugar de passagem ${ }^{23}$. Pode-se dizer, em outras palavras, que o olho recebe a impressão da beleza, enquanto a Alma percebe a forma do belo.

Ainda cabe notar que o ato (enérgeia) da Alma produziu (eirgásato) Eros como uma hipóstase e uma essência (bypóstasin kaì ousían); esta é a frase-chave para a relação entre Eros e Afrodite (WOLTERS, 1972, n. 2.36, 30). Quanto ao termo hypóstasin é errado considerar que Eros seja uma hipóstase, no sentido técnico com que usualmente são classificados o Um, o Intelecto e a Alma; com efeito, Eros é uma "realidade". De fato, não se deve pensar que se trata de um desdobramento das chamadas três hipóstases principais, o Um, o Intelecto e a Alma. Como nota Couloubaritsis $(1992,237)$, é fato que o termo "hipóstase" seja utilizado por Plotino em referência a uma "subsistência" qualquer, mas isso não deve eclipsar a especificidade das três hipóstases principais, nem a recusa de Plotino em acrescentar outras. Portanto, no caso de Eros, assim como do lógos, trata-se de uma espécie de desdobramento, da passagem de uma hipóstase a outra, sem que isso implique em uma hipóstase suplementar. Finalmente, é um modo de falar do ato pelo qual emerge uma outra coisa de uma das três

23. Tal metáfora, com sentido próximo a este, encontra-se também em IV, 4 [28] 24, 31, onde Plotino diz que o olho transmite à Alma o que ela vê. 
hipóstases, e que marca sua presença na hipóstase seguinte. Por sua vez, o ato da Alma é um olhar ardente (sphódra horốsess), intenso, dirigido à primeira essência (III, 5 [51] 3, 3-5) 24. Ora, a Alma e Eros são essências, porque ambos surgem desse olhar, mas também porque este olhar é simultâneo ao ato do Intelecto, que, olhando o Um, se constitui como a primeira essência ${ }^{25}$. A Alma sente alegria e uma espécie de prazer na visão do Intelecto, tanto assim que essa visão não pode ser algo secundário (III, 5 [51] 3, 5-10). Por isso ela gera Eros que, finalmente, surge do encontro entre esta tensão contemplativa da Alma e este como que eflúvio (hoîon aporréontos) proveniente do que é visto (III, 5 [51] 3, 11-12).

O verbo aporreîn é um termo técnico da teoria da visão, sendo registrado em Platão e em Alexandre de Afrodísia, mas que deriva, em última instância, da teoria da luz e da visão de Empédocles (WOLTERS, 1972, n. 3.12, 37). Platão, que possivelmente adaptou a teoria de Empédocles, associou érōs e esreîn no Crátilo (420 b): "Já o amor é assim chamado, porque flui de fora, e este fluxo não pertence àquele que o tem, mas é importado por meio dos olhos" (trad. Figueiredo) ${ }^{26}$. Embora não se sirva do mesmo jogo etimológico, Plo-

24. No Crátilo 420 a, é hímeros que atrai a alma com sua impetuosidade (sphódra).

25. O Intelecto é designado como "primeira essência" também em I, 8 [51] 2, 21; V, 3 [49] 5, 35.

26. Também associa a hímeros: "Quanto ao desejo (hímeros), este nome foi dado ao fluxo que mais arrasta a alma; porque se lança a fluir" (PLATÃO, Crátilo, 420 a - trad. Figueiredo). 
tino alude à ideia de que Eros escorre para a Alma, introduzindo-se do exterior pelos olhos. O que de certa forma também ecoa o Fedro (251 b): os eflúvios da beleza (kállous tèn aprrónē), penetrando pelos olhos, fazem com que as asas da alma comecem a crescer. Em outro tratado, Plotino retoma esta imagem: "No momento em que a Alma recebe em si o eflúvio que vem do Bem, que ela é atraída pela vida e pelo Intelecto (...) nasce o amor" (VI, 7 [38] 22, 8-10). Dessarte, para Plotino, Eros é um "olho repleto" (óma plērōthén), como uma visão que contém uma imagem (hoîon met' eidốlou hórasis - III, 5 [51] 3, 13). Esta imagem é a da beleza. Porque Eros está relacionado com a visão, Plotino em III, 5 [51] 3, 13-15 introduz um jogo etimológico, dizendo que possivelmente o nome amor (érōs) recebe sua realidade do ato de ver (horáseōs) ${ }^{27}$. A derivação ontológica reflete-se na derivação etimológica. Plotino joga com os registros genealógico e etimológico da palavra eros, estabelecendo uma relação entre o deus, o amor como estado de alma e o verbo amar. Decompondo o raciocínio, eis o que ele diz: o deus Eros é uma essência. Se o que é essência é anterior ao que não é essência, eros, o estado de alma, tira seu

27. Essa etimologia não corresponde à que Platão, no Crátilo 420 a, atribui a Eros (esrê̂n - correr de fora). É possível, por conseguinte, que Plotino a tenha tomado de uma tradição anterior. Em Etymologicum Magnum, 379, 48 (apud HADOT, in: PLOTIN, 1990, 188-189) encontra-se uma etimologia semelhante à de Plotino, significando que o desejo (Eros) vem aos homens pela visão sensível. Ora, isso está de acordo com a teoria do amor como um caminho de retorno ao Um que se encontra nos tratados I, 6 [1] e I, 3 [20], por exemplo. 
nome do deus Eros, ou seja, deste olhar que deriva do ato de ver da Alma. Donde o estado de alma seja designado pelo verbo amar (erân). Plotino introduz pois uma precisão gramatical, indicando que o verbo amar requer complemento. Com isso ele tenta mostrar que o amor, estado de alma, depende de outra coisa, por conseguinte, é relativo e não essencial. Por sua vez, tanto a Alma como o seu amor são independentes, separados, porquanto eles permanecem no inteligível, puros e sem mistura. Ainda que, de certo modo, a alma humana faça parte da Alma-hipóstase, esta se mantém no inteligível, não se misturando ao corpo (III, 5 [51] 3, 15-19). O que significa, na verdade, que uma parte da alma humana se mantém no inteligível. Isso explica a afirmação que aparece na conclusão da exegese de Afrodite e Eros Urânios: esta Alma e este amor urânios estão em nós, diz ele, sendo nossa melhor parte, ainda que sejam separados (III, 5 [51] 3, 25-27).

\section{A SEGUNDA AFRODITE}

Plotino não se detém longamente em explicar a segunda Afrodite; o que ele parece fazer é estabelecer certas diferenças entre ela e a Afrodite Urânia. Ao informar que há duas Afrodites, e distingui-las segundo a genealogia, Plotino também as diferencia por uma tarefa: a Urânia está acima das uniōes, pois no céu não há uniões (III, 5 [50] 2, 18). A segunda é supervisora das uniões daqui (ephaptoménèn éphoron gámōn - III, 5 [50] 2, 12-17). Em um primeiro golpe de vista, tal distinção faz com que a Afrodite Urâ- 
nia permaneça afastada do comércio corporal, aqui simbolizado pela união (gámos). O fato de a segunda Afrodite ligar-se a tal tipo de relação está de acordo com aspectos tradicionais do mito de Afrodite, deusa do amor, das estratégias de sedução e da procriação. Ademais, como nota Wolters (1972, n. 2.17, 24), o termo gámos pode referir-se a casamento, mas também a uniōes sexuais variadas, como, por exemplo, prostituição ou relações homossexuais. Em Plotino, parece referir-se a intercursos sexuais, com ênfase na corporeidade. Ainda é Wolters (1972, n. 2.17, 23) quem observa que o verbo epháptesthai nas Enéadas, "denota uma ligação com um nível ôntico particular, especialmente a alma inferior e o corpo ou a matéria”. Então a expressão ephaptoménèn gámōn (linha 18) marcaria um contraste com epékeina gámōn (linha 19), usada em referência ao céu. Ora, cabe lembrar que a relação de Afrodite Pandêmia com tais intercursos foi observada no discurso de Pausânias ${ }^{28}$.

Mas nessa passagem, curiosamente, Afrodite não recebe o qualificativo "Pandêmia", o que fez Lacrosse (1994, 43) imaginar que o epônimo é muito pejorativo para designar a alma. Ele não se afasta de Hadot (in: PLOTIN, 1990, 193), para quem Plotino evita o epíteto, porque, mesmo sendo inferior à Alma divina e a seu Eros, a alma do mundo e seu respectivo eros não são menos nobres. Wolters (1972, n. 2.17, 23)

28. Pausânias refere-se tanto a uniōes carnais heterossexuais, como homossexuais patrocinadas por Afrodite Pandêmia (PLATÃO, Banquete, 181 b). 
encontrou outra justificativa para a omissão do epíteto pándèmos: a descrição da segunda Afrodite não segue longamente o esboço de Platão, mas antes os cultos nos quais ela é chamada éphoron (patroness), em cujos templos havia hetairas. Ele nota, ainda, que Plotino alude à conexão entre Afrodite segunda e as hetairas no tratado VI, 9 [9] ${ }^{29}$, onde, aliás, Plotino usa o epíteto Pandêmia. Nesse caso, se em outro tratado Plotino adjetiva assim Afrodite, parece que os argumentos de Hadot, Lacrosse e Wolters perdem um pouco da força. Apesar de se poder até admitir que Plotino aluda aos cultos, como faz Wolters, porém essa não seria razão suficiente para eliminar o epíteto.

Mas por que então Plotino não mantém o epíteto no tratado III, 5 [50]? Talvez porque lhe interesse nesse tratado sublinhar seu aspecto de intermediária entre o inteligível e o sensível, e não um caráter mais terreno, que seria acentuado pelo termo Pandêmia. De fato, esta Afrodite corresponde à alma do mun$\mathrm{do}^{30}$, que, por sua vez, desdobra-se nas almas individuais $^{31}$. Por isso, parece mais interessante a observa-

29. A passagem é: "Pois também lá está a Afrodite Urânia, mas aqui, se torna Pandêmia, como que prostituída" (VI, 9 [9] 9, 29-30 trad. Brandão, ligeiramente modificada).

30. "Contudo, uma vez que essa Afrodite é a alma deste cosmos, não meramente alma qualquer nem alma sem mais, e que ela engendrou Eros neste cosmos (...)" (III, 5 [50] 3, 30-32 - trad. Baracat Jr., ligeiramente modificada).

31. "Contudo, deve-se pensar que haverá também muitas Afrodites no universo, que como daimones nele se originaram em companhia de Eros, fluindo a partir de uma Afrodite universal e dela dependendo essas muitas particulares com seus próprios eros (...)" (III, 5 [50] 4, 18-22 - trad. Baracat Jr., ligeiramente modificada). 
ção de Ucciani (1998, 184), segundo o qual Plotino não usa o termo Pandêmia, porquanto não aborda o significado; o salto se faz de Urânia a daímōn. Com efeito, a segunda Afrodite é daimônica porque produz um Eros daimōn, cujo sentido remete tanto ao amor do cosmos, que mantém a alma do mundo ligada ao inteligível, como àquele amor que acompanha cada indivíduo neste mundo e que pode conduzi-lo ao alto.

\section{O SEGUNDO EROS: DAÍMŌN}

Plotino não descreve nem explica longamente a segunda Afrodite, todavia dedica-se mais amplamente ao daímōn Eros. De início, por um lado, ele mostra analogias entre Eros e Afrodite, por outro, diferenças. Mas, além disso, o conceito de daímōn serve de transição para o mito de Poros e Penía, observando-se especialmente que, nessa passagem, o caráter intermediário do daímōn deixa de ser definido relativamente à noção de olhar, passando a ser compreendido a partir da situação mediana entre a abundância e a falta.

Seguindo a ordem do tratado, assim como a segunda Afrodite, o Eros do mundo supervisiona (ephaptómenon) as uniōes (III, 5 [50] 3, 32-33). Plotino faz uso do mesmo verbo (epháptesthai) que já utilizara para descrever a relação entre Afrodite segunda e as uniōes, denotando, portanto, uma similaridade entre ambos, pois quanto a esse aspecto, Eros e Afrodite realizam um mesmo tipo de ação. Mas significa, igualmente, que essa ação está ligada a um plano específico, o da alma inferior unida ao corpo. 
Porém, Eros tem uma outra função, também designada pelo mesmo verbo: ele dedica-se (epháptetai) ao desejo de elevação (tês oréxeōs tês ánō - III, 5 [50] 3, 33-34). Desse modo, Eros estimula os jovens, fazendo com que a alma à qual está unido volte-se para o alto, porquanto ela possui a capacidade de rememorar as realidades inteligíveis (III, 5 [50] 3, 34-36). Plotino explica que tal Eros não é o mesmo em cada alma. Esse daímōn infunde desejos (epithymías) conforme a natureza de cada alma, pois em cada qual o desejo é análogo à sua própria natureza e engendra seu eros conforme seu nível e sua essência (III, 5 [50] 4, 4-9). Portanto, Eros da segunda Afrodite é o daimōn que acompanha cada pessoa, o Eros de cada um (III, 5 [50] 4, 4-6). Além disso, assim como o deus Eros, que representa o olhar da Alma em direção ao Intelecto e ao Um (III, 5 [50] 3, 28-29), o daimón Eros também representa o olhar em ato da alma do mundo e, por extensão, das almas individuais. Traduzindo em termos metafísicos, Eros-daimōn é o olhar amoroso em ato dirigido para o alto, ou seja, é efetivamente o amor que a alma do mundo e as almas individuais nutrem por sua origem, e que as eleva, as unifica. Mas qual é a relação entre o amor da alma do mundo e o das almas individuais? A resposta de Plotino parece indicar que o amor da alma do mundo se subdivide em numerosos amores particulares, os quais são como que manifestaçóes daquele amor cósmico:

E, na mesma medida em que cada alma não se encontra apartada da total, mas está nela compreendida de tal modo que todas 
sejam uma só, também o amor individual está no universal; mas, por sua vez, o amor particular coexistirá com cada alma particular, e aquele grande amor, com a alma total, e o que está presente no universo, com o universo em todas as suas partes; e esse amor uno, por sua vez, far-se-á e será muitos, manifestando-se em qualquer parte do universo que queira, configurando-se como partes de si mesmo e assim se manifestando, se quiser (III, 5 [50] 4, 13-18 - trad. Baracat Jr.).

Depois disso, faz a passagem para a parte seguinte do tratado, dedicada à noção de daímōn, voltando à linguagem mítica e mostrando a ligação entre as Afrodites e Eros, conforme o que foi avançado até esse ponto do tratado. Com efeito, ele retoma a tese de base, qual seja: a Alma é mãe de Eros; Afrodite é a Alma e Eros é a atividade da Alma que tende ao Bem. A partir dessa Afrodite universal, fluem (rhueisas) muitas Afrodites como daimones, acompanhadas de seu Eros, que daquela dependem (III, 5 [50] 4, 18-23) . $^{32}$.

Os capítulos 5 e 6 tratam da noção de daímōn, a qual serve de transição para a exegese do mito de nas-

32. Aqui é interessante notar que há em Plotino um tratado dedicado à noção de daímōn, III, 4 [15]. Neste tratado, o daímōn diferentemente da tradição que remonta a Homero e Hesíodo, passando por Platão, não é um acompanhante externo, mas se identifica com a própria Alma. Há, contudo, diferenças entre o daímōn em III, 4 [15] e em III, 5 [50]. Todavia, não é possível adentrar nos meandros deste tema, devido aos limites do presente estudo. 
cimento de Eros, no discurso de Pausânias para o de Sócrates e Diotima. O capítulo 5 evoca certas aporias e contradiçôes entre diálogos platônicos, propondo questôes que serão resolvidas posteriormente. O capítulo 6 é de maior interesse para a investigação da natureza daimônica, assim como os três capítulos finais, que mencionam o daímōn em conexão ao mito de Poros e Penía. Embora não seja possível, aqui, adentrar profundamente no tema do daimōn nas Enéadas, parece que o estudo da natureza daimônica e, em especial, do daimōn Eros são fundamentais para compreender o significado do mito de Eros, além de permitir a passagem do mito de Afrodite para o de Poros e Penía ${ }^{33}$.

Plotino enfatiza a relação entre os daimones e as figuras de Poros e Penía ao menos duas vezes, nos capítulos que se ocupam em definir o daímōn. Na primeira passagem, Plotino indaga sobre qual a natureza dos daímones e sobre qual o sentido que se deve dar à narrativa do Banquete na qual Eros foi gerado por Poros, filho de Métis, e por Penía, na festa do nascimento de Afrodite (III, 5 [50] 5, 1-4) ${ }^{34}$. Com essa questão, Plotino procura investigar ao mesmo tempo a natureza do daímōn Eros e dos daímones em geral, considerando que a descrição do nascimento de Eros no Banquete poderá fornecer uma resposta (HADOT, in: PLOTIN, 1990, 203). Na segunda passagem, que é também uma indagação, Plotino diz que é mister precisar quem são

33. Nesse sentido, discorda-se de Dillon (1969, 34), que diz: "Esta seção sobre a natureza dos daímones é de grande interesse, mas não é relevante para a exegese do mito (...)".

34. Cabe notar que é esta a única ocorrência da figura de Métis nas Enéadas, a qual não é objeto de interpretação. 
Poros e Penía, genitores de Eros daimōn. Em seguida, surgem outras questões, das quais duas são dignas de relevo: serão filhos de Poros e Penía todos os daimones, uma vez que todos eles possuem a mesma essência em comum? E qual a diferença entre os deuses e os daímones (III, 5 [50] 6, 1-6)? Essas duas perguntas devem ser vistas preliminarmente ao estudo do mito de Poros e Penía, pois introduzem alguns temas do mesmo.

Quanto à questão da diferença entre uns e outros, note-se que a distinção entre deuses e daimones "decorre do fato de que em grego antigo ou poético os dois termos são utilizados indistintamente para designar os deuses" (HADOT, in: PLOTIN, 1990, 206). Parece ser a isso que alude Plotino, quando assegura ser preciso deslindar os deuses dos daimones, mesmo que se diga que os daimones são deuses (III, 5 [50] 6, 7-9). Ele estabelece a diferença entre uns e outros primeiro através dos conceitos de apathếs e páthos: "Afirmamos e pensamos que o gênero dos deuses é não suscetível (apathếs), ao passo que aos daimones atribuímos suscetibilidades (páthēe)" (III, 5 [50] 6, 9-11 - trad. Baracat Jr. ligeiramente modificada) ${ }^{35}$. Com efeito, as páthē corres-

35. A tradução de páthē aqui se complica, pois não é possível empregar a expressão estado da alma para os daímones. O próprio Hadot, que traduz páthos por estado da alma, aqui traduz páthẻ por passions. Wolters, por sua vez, traduz por affection. Oscilando entre os termos paixão e afeç̧ão, os demais tradutores tampouco apresentam uma solução melhor para páthè. Talvez, em português, fosse melhor usar o adjetivo "passível", como sinônimo de "suscetível", o qual também parece que poderia ser empregado na referida tradução. Mas, para não traduzir um substantivo por 
pondentes aos daimones se justificam no fato de os daimones serem, como lembra Hadot (in: PLOTIN, 1990, 212), a personificação do desejo de cada alma, isto é, do papel que cada alma deve desempenhar no universo, e que é imposto pela alma do mundo. Em outros termos, o daímōn é a personificação do destino individual de cada $\mathrm{alma}^{36}$. $\mathrm{O}$ daímōn Eros é, assim, o ato personificado da alma, o olhar de cada uma. Ele varia, portanto, segundo a faculdade que predomina na alma (III, 5 [50] 7, 32-36) ${ }^{37}$. Então Plotino assegura que os daimones são intermediários entre os deuses e os humanos (III, 5 [50], 6, 11-12) ${ }^{38}$. Com isso, a noção de intermediário assume um novo matiz, deslocando-se do registro do olhar. E, ao mesmo tempo, é enfatizado o duplo aspecto do Eros da alma inferior: por um lado, ele está ligado ao Eros da Alma, por outro, com a multiplicidade de desejos indeterminados da alma humana. Ora, "o desejo permanece indeterminado enquanto não se converte em desejo do Bem, enquanto ele não unifica sob esse único desejo a multiplicidade de desejos" (PIGLER, 2002, 195). Nem todas as almas

um adjetivo, talvez fosse mais adequado suscetibilidade. Baracat traduz por afecções, onde se modificou, usando suscetibilidades.

36. Ver a respeito VI, 7 [38] 7, 9-16. Para Wolters (1972, n. 4. 6-9 e n. 4. 6, 48), a identificação do segundo Eros com o daímōn pessoal da tradição popular, explica, não somente o último lugar do desejo natural na hierarquia, mas também explica sua causa.

37. Pode estar ligado tanto à faculdade racional, como à sensitiva ou à vegetativa.

38. No Banquete 202 e, Diotima fala que o daimōn é um ser intermediário entre os deuses e os homens 
humanas desejam o Bem. Algumas desejam bens particulares que têm alguma relação com a administração do mundo sensível (III, 5 [50] 6, 30-33). Se nem todas as almas desejam as mesmas coisas, é porque há diferentes daímones, embora todos possuam a mesma essência. Com isso, a questão acerca da genealogia mítica dos daímones, se todos são filhos de Poros e Penía, converte-se em outra pergunta: por que todos os daimones não são Eros? (III, 5 [50] 6, 27). Por certo, não podem sê-lo, uma vez que correspondem a desejos distintos. Todavia, todos têm a mesma essência, porquanto se originam na alma do mundo (III, 5 [50] 6, 32-33). Mas somente Eros nasce do desejo do Bem e do belo (III, 5 [50] 6, 28-29); somente ele é o olhar amoroso da alma em direção ao princípio ${ }^{39}$.

Finalmente, para não perder de vista a complexidade da noção de Eros daímōn e, desse modo, preparar a leitura do mito de Poros e Penía, é mister observar que, por seu caráter intermediário, o amor da alma do mundo está em parte ligado ao amor da Alma e em parte à multiplicidade de desejos indeterminados das almas humanas (III, 5 [50] 4, 22-25). Nas palavras de Pigler $(2002,196)$, "os dois erôtes da Alma estão em contato, o inferior estando sempre na órbita do superior, do qual ele participa e graças ao qual sua

39. E isso, já é sabido, vale para Eros deus e para Eros daímōn: "Portanto, esse eros que conduz cada alma para a natureza do Bem será um deus, se for o da alma superior, um deus que mantém a alma sempre em contato com aquele, ao passo que será um daimōn, se for o da alma mesclada" (III, 5 [50] 4, 23-25 - trad. Baracat Jr., ligeiramente modificada). 
potência nunca perde contato com a potência erótica infinita e ilimitada saída do Um”. Destarte, enquanto Eros promove a relação ascendente entre os níveis de realidade, o lógos é responsável pela descendente. Em outros termos, Eros é o desejo pelo Bem, portanto é olhar da Alma, em todos os seus níveis, em direção ao Bem. O lógos, por sua vez, é aquilo que escorre de cada nível superior em direção ao inferior, o constituindo-o enquanto tal. Eros e lógos são noções que se complementam e explicam as duas vias de ligação entre as realidades. Por isso, no mito de Poros e Penía, a noção de lógos adquire relevo, sendo desenvolvida através da interpretação de diversas figuras míticas. No entanto, cabe notar que há um outro conceito relacionado ao de daímōn importante para a compreensão do mito de Poros e Penía, o qual faz realmente a passagem de uma parte à outra do tratado. Surge, no final do sexto capítulo, a indagação acerca da participação dos daímones na matéria. Plotino explica que, mesmo considerando a possibilidade de existência daqueles daimones, que possuem corpos ígneos ou aéreos ${ }^{40}$, nem mesmo eles participam da matéria sensível, pois, se participassem, seriam animais sensíveis, o que significa que ordinariamente eles seriam perceptíveis pelos sentidos físicos ${ }^{41}$.

40. Essa noção encontra-se também em II 1 [40] 6, 54; VI 7 [38] 11,$53 ; 67-68 ; 12,12$. Mas Plotino não parece considerar que os daimones tornem-se corpóreos para aparecerem. Nem mesmo que os corpos aéreos ou ígneos os tornem visíveis.

41. Plotino refere-se a tal possibilidade, mas não menciona apariçôes de daimones. Todavia, considerando-se o tratado conhecido por $A d$ Gaurum, supostamente de autoria de Porfírio, este explica tais apariçôes pela projeção de uma imagem no envelope vaporoso que os entorna (Ad Gaurum, 42, 5 ed. Kalbfleisch = Festugière, p. 277). 
Eles possuem então uma matéria inteligível que, não obstante, comunica-se com a matéria sensível, permitindo que os daimones possam participar do corpo. Isso porque tal matéria parece ser intermediária entre o incorpóreo e o corpóreo, pois o que é totalmente puro não se mescla ao corpo (III, 5 [50] 7, 35 ss). Tal matéria será descrita no capítulo seguinte do tratado, associada à figura de Penía.

\section{O MITO DE POROS E PENÍA}

Enquanto os dois mitos de Eros associados às figuras de Afrodite Urânia e da segunda Afrodite concernem ao olhar contemplativo das duas partes da Alma em direção ao Um/Bem, a exegese do mito de Poros e de Penía explica o movimento de passagem do Intelecto até à parte inferior da alma, em seus dois sentidos, epistrófico, simbolizado pela figura de Eros, e processional, através da noção polissêmica de lógos. $\mathrm{O}$ mito pode ser representado esquematicamente assim:

\begin{tabular}{|c|c|c|c|c|c|}
\hline Zeus & Intelecto & & & & \\
\hline \multirow{5}{*}{ Afrodite } & \multirow{5}{*}{ Alma } & Poros & Logos & & \\
\hline & & & & Expansāo do lógos & Néctar \\
\hline & & & & Alma & Jardim \\
\hline & & & & Lógoi difundidos & $\begin{array}{l}\text { Objetos do } \\
\text { jardim }\end{array}$ \\
\hline & & Penía & matéria inteligível & & \\
\hline \multicolumn{3}{|c|}{ Eros daimön } & Desejo do Bem & & \\
\hline
\end{tabular}

Percebe-se de imediato que este esquema é mais complexo que os anteriores. Ele possui colunas desi- 
guais e linhas seccionadas. Para compreendê-lo, tornase preciso lembrar o princípio de intemporalidade, que rege a interpretação dos mitos. Todas as genealogias são simultâneas e estão representadas nas quatro colunas superiores, à esquerda. Eros é o fruto das duas relaçôes míticas, de Zeus e Afrodite e de Poros e Penía. $\mathrm{O}$ nascimento de Eros ocorre no dia em que se festeja o nascimento de Afrodite, no jardim de Zeus, o qual é repleto de ornamentos. Nesse lugar, os deuses bebem néctar, e Poros está dormindo embriagado. O jardim alude à Alma replenada de lógos. $\mathrm{O}$ néctar e os objetos do jardim são símbolos de estados do lógos o qual procede do ato do Intelecto que produz a Alma. As linhas seccionadas têm o fito de mostrar a interpenetração desses elementos, além da sua simultaneidade. Poros e Penía concebem Eros no jardim de Zeus, isto é, o encontro de ambos representa a difusão do lógos do Intelecto na matéria inteligível da Alma. Por isso Poros não está separado graficamente do Intelecto, embora ele se situe no nível da Alma. O lógos do Intelecto difunde-se, dando vida à Alma. Esta, como é consabido, possui duas partes; para que se constitua, é necessário que o lógos se difunda por toda ela, incluindo a alma do mundo, de onde os lógoi escorrem para as almas individuais que dela derivam. Portanto, se o lógos pode difundir-se até ao limite da processão, é necessário que Eros também esteja presente no limite. Eros, filho de Poros e Penía, é complemento do lógos: enquanto o lógos saturado procede do Intelecto, Eros olha em direção à origem última e a deseja, permitindo o retorno de todas as almas ao Bem. 
Contudo, é mister advertir que, dada a complexidade deste mito, encontra-se certa disparidade de interpretaçōes na literatura secundária. Com efeito, enquanto o primeiro terço do tratado, que se ocupa da genealogia de Afrodite e Eros, pouco deteve os comentadores de Plotino, esta parte do tratado, que versa sobre o mito de Poros e Penía, ocupou alguns ${ }^{42}$, não tendo sido unanimemente interpretada. Dados os objetivos deste estudo, não será apresentada uma discussão em torno das divergências encontradas nas fontes secundárias, que seria imprescindível apenas em um trabalho que se detivesse exclusivamente na análise detalhada do tratado III, 5 [50]. Porém, podem registrar-se sumariamente certas dissensões entre os dois principais comentadores, observando que, por trás dessa diversidade de interpretações, está o simbolismo plotiniano da figura de Afrodite da narrativa de Sócrates. Ou seja, nem a Urânia, nem a Pandêmia do discurso de Pausânias, mas aquela cujo natalício era

42. De fato os estudos mais completos e indispensáveis para o estudo do tratado III, 5 [50] são Wolters (1972), que consta de uma edição bilíngue do texto, cuja tradução é comentada em detalhes, especialmente do ponto vista filológico. O outro estudo é o de Hadot (in: PLOTIN, 1990). Diferente da edição de Wolters, a de Hadot privilegia aprofundar aspectos da filosofia de Plotino nos comentários. Por serem profundos e eruditos, ambos os textos se complementam no estudo do tratado III, 5 [50]. Além desses, podem-se mencionar os seguintes artigos e capítulos de livros, observando que, excluído Lacrosse, os demais autores detêm-se apenas no mito de Poros e Penía: LACROSSE, 1995, 131-147; 1969, 24-44. HARRINGTON, 1975, 115-125. COULOUBARITSIS, 2000, 182-199. PIGLER, 2002, 180-198. 
festejado quando da concepção de Eros. Para Hadot (in: PLOTIN, 1990, 72), ela representa a alma do mundo, mas, nesse caso, surge a dificuldade em explicar a passagem do lógos do Intelecto para esse nível inferior da alma. A mesma dificuldade permanece se Zeus é associado ao intelecto da alma, solução proposta por ele. Por isso Hadot sugere que Poros e Penía representem dois aspectos da alma do mundo: "Poros representa a alma do mundo na medida em que ela é extensão das formas que se interpenetram no Intelecto, extensão ao longo da qual as formas do Intelecto na alma tornam-se 'razóes' (lógoi) em todos os sentidos filosóficos da palavra (definição, razão, força produtora)". Penía, por seu turno, desempenha o papel da alma do mundo, quando ela se torna o receptáculo, a matéria dos lógoi que escorrem do Intelecto nela. Essa leitura é internamente coerente e, além disso, fundamenta-se na passagem do primeiro para o terceiro terço do tratado, que é feita, como foi visto, através da noção de daímōn. Além do quê, pesa a favor dessa interpretação o fato de Eros, no discurso de Sócrates e Diotima, no Banquete, ser um daímōn.

Wolters (1972, XIII), por sua vez, com respeito à exegese do mito do Banquete, considera que a interpretação plotiniana de Eros, composto pela determinação e pela indeterminação na Alma, representa a necessidade constitucional da Alma em ser satisfeita com a pura determinação no Intelecto. Em outras palavras, representa a atividade da Alma em seu esforço de contemplar o Bem. O fato de Eros nascer, quando Afrodite nasce, indica que Eros e seus pais pressupóem 
a existência da Alma. Em outros termos, ele associa a Afrodite deste mito à Alma total. Poros é "a possessão da forma racional na Alma", Penía "a falta de forma racional na Alma”. A interpretação de Wolters também é coerente, mas não dá conta da passagem dos primeiros capítulos para os finais, mediante a noção de daímōn.

A interpretação aqui sugerida fundamenta-se em dois princípios metodológicos que se encontram nas Enéadas. O primeiro, já anunciado, é o da acronia das realidades metafísicas representadas pelos mitos. Significa que Afrodite, Zeus, Poros, Penía e Eros representam realidades simultâneas, mas que devem ser dispostas segundo uma ordem hierárquica. Em outros termos, o primeiro princípio metodológico convertese no seguinte princípio interpretativo: o mito póe em modo temporal realidades acronológicas. $\mathrm{O}$ segundo princípio concerne à polivalência alegórica em um dos seus aspectos: uma mesma noção filosófica corresponde a diferentes figuras míticas. E uma mesma figura mítica corresponde a diferentes noções filosóficas ou, em outros termos, realidades metafísicas. Com isso, o segundo princípio metodológico, da polivalência, coincide com certos aspectos da perspectiva alegórica dos mitos, como se poderá ver mais detidamente à frente. Por isso, na presente interpretação, admite-se a continuidade entre uma parte e outra do tratado através da noção de daimōn, considerando-se Eros filho de Poros e Penía como daímōn. Mas também julgase plenamente admissível que Afrodite represente a Alma total; donde, o mito final do tratado III, 5 [50] apresenta um esquema completo da relação entre o 
Intelecto e Alma o qual se estende até ao nível inferior desta. Assim sendo, do ponto de vista metodológico, Plotino teria apresentado uma solução capaz de conciliar os mitos de Afrodite e Eros do discurso de Pausânias, com aquele do discurso de Sócrates e Diotima, na medida em que a Afrodite desse mito reabsorve as duas Afrodites provenientes do discurso de Pausânias. Quanto a Eros, se Plotino mantém seu caráter daimônico, por um lado, possivelmente é em referência ao último discurso do Banquete. Por outro, ao situar Eros nos píncaros da processão, ele fecha o tratado, explicando, por outra via, que o amor é algo misto. Esse caráter do amor justifica a existência de diferentes tipos de amor humano, tema que ocupa o primeiro capítulo do tratado.

\section{O SIGNIFICADO FILOSÓFICO DAS FIGURAS MÍTICAS}

As figuras de Poros e Penía aparecem normalmente juntas nas Enéadas ${ }^{43}$ caracterizando a estrutura mista de Eros, que possui, ao mesmo tempo, a euporia e a

43. Segundo Zamora (2000, 186), elas aparecem "entrelaçadas conformando uma estrutura hilemórfica, à qual Plotino adiciona a doutrina estóica dos lógoi spermatikoí. Deste modo, a exegese plotiniana do mito platônico do Banquete utiliza elementos que não são propriamente platônicos, mas que pertencem a teorias aristotélicas e estóicas, boa parte delas fundidas durante o médio platonismo". Nos limites do presente estudo será vista apenas a transposição das figuras míticas para os níveis hierárquicos correspondentes na filosofia de Plotino, com atenção apenas a aspectos da exegese do texto de Platão. 
aporia $^{44}$. Ou, em outros termos, Eros possui a natureza intermediária entre o divino e o não-divino. No Banquete, Poros é um deus; Penía é a personificação da natureza não-divina (hē thnētè phýsis) ${ }^{45}$.

Desconhecido nos mitos tradicionais, Poros é filho de Métis (PLATÃO, Banquete, 203 b) ${ }^{46}$, uma divindade primordial que representa o pensamento primeiro. Métis é o princípio de todas as habilidades, de todas as descobertas; é fonte inesgotável de invenções. Ela está na origem dos traços de inteligência helênica, cujo herói é Odisseu. O nome Poros significa, no sentido figurado, recurso. Em sentido próprio, designa passagem, via de comunicação, mas também um curso d'água. Significa, ainda, a ação de passar através, o trajeto. Também a ação de adquirir, obter.

Penía, a mãe de Eros, por sua vez, não é exatamente uma divindade. Ela é a personificação da pobreza, sendo este o sentido do nome que Platão lhe atribuiu - observe-se que ela tampouco figura nos mitos tradicionais. Enfim, Penía é uma errante que vem mendigar na mesa dos deuses. Sem recursos, na aporia, literalmente, em um beco sem saída, em um lugar sem passagem, ou em uma situação difícil, embaraço-

44. Esta noção provém do Banquete 204 b: "Ora, a causa de tais características <de Eros $>$ reside justamente na sua origem: de uma parte, um pai sábio e engenhoso (eúporos); de outra, uma mãe desprovida de sabedoria e de recursos (aporía)" (trad. Azevedo).

45. No Banquete 202 e, Platão diz que o daímōn é um intermediário entre o divino e o não-divino (metaxù theoû te kaì thnētô̂).

46. Embora Poros não apareça nos mitos tradicionais, Platão não foi o primeiro a personificá-lo: ele aparece em Alcman, frag. 1, v. 14; frag. 5.2, col II, v. 19, como mostrou Brisson (2000, n. 392, 210). 
sa, contra a qual não se pode lutar, ela está sempre a caminho, em busca de meios ${ }^{47}$. Vendo Poros embriagado de néctar, adormecido no jardim de Zeus, por ocasião de uma festa em homenagem ao nascimento de Afrodite, Penía decide ter um filho de Poros para sair da aporia (PLATÃO, Banquete, $203 \mathrm{~b}-203 \mathrm{c})^{48}$. E assim, deitando-se ao lado de Poros, ela concebe Eros.

Porque Eros foi concebido na ocasião do banquete em homenagem ao nascimento de Afrodite, ele tornase seu seguidor e servidor. Ele é amante do belo, uma vez que Afrodite é bela. Por ser filho de Penía, ele é pobre, sem recursos, rude, malvestido, anda com os pés descalços, dorme ao relento, nas soleiras das portas e na beira dos caminhos. Por ser filho de Poros, ele tem a força divina, temível, e a veemência do desejo. Assim, ele não mendiga como sua mãe; ele encanta o que deseja, com a força divina que herdou de seu pai. Ele é, então, a exemplo do pai, viril, resoluto, ardente; está sempre à espreita do que é belo e bom. É um caçador temido, que trama ardis. É apaixonado pelo saber e é fértil em expedientes como Métis, sua avó paterna. Eros passa seu tempo a filosofar (PLATÃO, Banquete, 203 c - 203 d). Com efeito, se Eros ama a beleza,

47. Sobre os significados dos nomes de Poros e Penía, ver GALPÉRINE (1996, 18 e 20). Para o significado geral dos termos penía, póros, áporos foi consultado o dicionário grec-français de Anatole Bailly.

48. A propósito, Bury (1973, XLI), em sua introdução ao Banquete, observa que Poros nunca foi vítima dos encantos de Penía, uma vez que ela não os possuía. Tampouco Penía tentou obter Poros por persuasão, ou por força. Ele se entregou a ela com a força e a maravilha de um deus. Obviamente ele foi enganado, pois seus sentidos estavam cegos. 
ele ama igualmente a sabedoria, pois esta consta entre as coisas mais belas, por isso ele é naturalmente filósofo (PLATÃO, Banquete, 204 b). Ora, um deus não filosofa, não busca a sabedoria, porquanto ele já a possui. Tampouco um ignorante pode buscá-la, na medida em que não tem a consciência de ignorar. Por conseguinte, a filosofia é um intermediário entre a sabedoria que se sabe, e a ignorância que se ignora, que é desprovida de desejo. A filosofia é a inquietude humana, é a "ignorância que se sabe", que não deixa a alma em repouso. Assim, pode-se dizer que Platão, através desse mito, fez do amor o símbolo da condição humana na sua dualidade essencial ${ }^{49}$.

Embora Plotino não se desvie completamente de Platão, quando identifica Penía com a matéria (BURY, 1973, XLI), que é carente de ser, pobre, apórica, definida por sua indeterminação, ao passo que Poros representa o lóos determinado do Intelecto, repleto de ser, belo, eupórico, sua exegese parece perder de vista todos aqueles valores docemente evocados sob um tom de delicada ironia, como diz Hadot (in: PLOTIN, 1990, 71). Plotino de fato parece não dar muita atenção à discussão sobre o filósofo e a sabedoria presente no discurso de Dioti-

49. A este respeito, ver Platão, Banquete, 204 a-c. Sobre o assunto ver GALPÉRINE (1996, 22); VERNANT (1989, 153-171). A narrativa mítica finalmente conclui-se com Diotima explicando que, por natureza, Eros não é mortal, nem imortal. Em um mesmo dia, diz ela, tanto ele floresce como ele morre. Depois ele retorna à vida, quando seus expedientes dão resultados, mas tudo o que obtém através de seus expedientes lhe escapa. Eros então nunca está nem na indigência, nem na opulência, o que reitera o caráter de intermediário do amor (PLATÃO, Banquete, 203 e). 
ma narrado por Sócrates. Talvez porque a exegese de Plotino situe-se em uma tradição de interpretação metafísica do Banquete que se encontra, por exemplo, em Plutarco. No Sobre Isis e Osíris, Isis é Penía, a matéria. Osíris é Poros, o bem, o primeiro amável e desejável. Eros, que nasce da união de ambos, é Horus, o mundo sensível, imagem do mundo inteligível, filho do bem e da matéria (PLUTARCO, Sobre Ísis e Osíris, 57, Moralia, $374 \mathrm{c}-\mathrm{e}$ ). À diferença de Plutarco, entretanto, Plotino não identifica Eros ao mundo. Logo no início da exegese do mito, Plotino deixa claro tratar-se de figuras míticas que representam aspectos do inteligível:

E por isso, no nascimento de Eros, Platão diz que 'era de néctar a embriaguez que tinha Poros, pois ainda não existia vinho' ${ }^{150}$, com o sentido de que Eros nasceu antes do mundo sensível (III, 5 [50] 7, 1-4 - trad. Baracat Jr., ligeiramente modificada) ${ }^{51}$.

Pois bem, Plotino segue a exegese, introduzindo a figura de Penía, a qual também faz parte da natureza inteligível (III, 5 [50] 7, 4-7) ${ }^{52}$. Ela da à luz a Eros

50. Referência a Platão, Banquete, 203 b 5.

51. Plotino havia anunciado o comentário do mito de Poros e Penía no capítulo 5, 1-4 e em 6, 1-3, mas somente nesta passagem o inicia.

52. Nessa passagem Plotino é enfático em marcar a diferença entre a matéria do inteligível, Penía, e a matéria do sensível, a qual só pode participar do inteligível no sentido de uma imagem ou reflexo. Penía, ao contrário, faz parte da natureza inteligível. A consequência disso é que Eros se mantém livre do mal e da feiúra representados pela matéria do sensível. 
unida com uma forma (symmikhtheisès hōs ex eídous - III, 5 [50], 7, 6) ${ }^{53}$. Penía é a "indeterminação que a Alma possuía antes de atingir o Bem, mas já pressagiando que ele era algo real" (III, 5 [50], 7, 7-8 - trad. Baracat Jr. $)^{54}$. Uma ideia semelhante é expressa em um tratado anterior, onde Plotino assegura que todas as coisas aspiram ao Bem e o desejam em virtude de uma necessidade natural, como se pudessem pressentir que sem ele não podem existir $(\mathrm{V}, 5 \text { [32] } 12,7-9)^{55}$. O verbo apomanteúomai aparece, ainda, em um outro tratado, indicando que, mesmo aqueles que não possuem nenhuma compreensão do Bem, podem pressentir haver algo além do Intelecto (VI, 7 [38] 29, 22). Portanto, voltando à figura de Penía, ela corresponde, ao mesmo tempo, a um estado de desejo e a um estado de ignorância (HADOT, in: PLOTIN, 1990, 217). Ela não sabe o que é o Bem, mas ela pressagia o que é e o deseja.
E Penía é a matéria porque também a matéria é indigente em tudo e porque a indeterminação do desejo pelo Bem - pois não há nem confi- guração (morfế) nem lógos naquele que deseja o Bem - torna aquele que deseja, na medida em que deseja, mais afim com a matéria (III, 5 [50] 9, 49-53 - trad. Baracat Jr., modificada).

53. Aqui, note-se, Poros é associado à forma.

54. Wolters (1972, n. 7. 7-8, 69) sugere que esta passagem é uma alusão a República 505 e: "Ora, aquele bem que toda alma procura, e por causa do qual faz tudo, adivinhando-lhe o valor, embora ficando na incerteza e sendo incapaz de apreender ao certo o que é" (trad. Pereira).

55. Aqui a referência também parece ser a República, 505 e. 
O desejo tem, por conseguinte, relação com a indeterminação. Conforme mostrou Arnou (1967, 6566), aquele que deseja não é completo ${ }^{56}$. É alguém que possui um futuro, pois o presente é essencialmente indigente. É alguém cujo ser consiste em tornar-se; nesse sentido é como a matéria, sempre em potência. Por isso, quem deseja tem afinidade com a matéria. Ora, diz Arnou (1967, 71), o desejo infinito e indeterminado da matéria significa "a imensa vontade de viver (vouloir-vivre) que agita a natureza, que é seu fundamento e como uma força sempre orientada, empurrando-a em busca da determinação". Com o fito de satisfazer tal desejo, Penía une-se a Poros, gerando Eros (III, 5 [50] 7, 9-12). Em síntese, pode-se dizer que Penía é a matéria inteligível indeterminada, porquanto participa da Alma superior (Afrodite), recebendo dela o fruto da sua contemplação, o lógos, e engendrando o Eros inferior, com o qual ela presenteará aqueles que a seguem (PIGLER, 2002, 183) ${ }^{57}$. Então esse aspecto de Eros, associado às figuras de Poros e Penía, surgiria concomitantemente ao aspecto superior de Eros, nascido do olhar da alma superior em direção ao Bem. E junto, além disso, com a alma do mundo, que resulta do mesmo movimento.

Poros é, então, o lógos presente no Intelecto. Mas é também um lógos que não permaneceu em si mesmo,

56. Alusão a Platão, Banquete, $202 \mathrm{~d}$

57. A autora diz ainda: Penía, que é a matéria inteligível, mas que, devido à sua participação, é da mesma natureza do inteligível, representa a alma inferior (PIGLER, 2002, p. 184). A hipótese não é absurda, haja vista a polivalência dos mitos. 
pois se mesclou à indeterminação, sendo considerado um lógos derivado do lógos (III, 5 [50] 7, 15-19). Como já foi visto, lógos é uma noção polissêmica para Plotino. Donde, diferentes sentidos do lógos serem representados por distintas figuras míticas, como Poros, o néctar e as coisas esplendorosas que se encontram no jardim de Zeus. Quanto a Poros, Plotino remete a seu duplo significado em um mesmo passo: "Então, como Poros é o lógos presente nas coisas do inteligível e no Intelecto, e como é mais difuso e por assim dizer expandido (mâllon kekhyménos kaì hoîon aplōtheis), ele se relacionaria com a Alma e estaria na Alma” (III, 5 [50] 9, 1-3 - trad. Baracat Jr. $)^{58}$. Aqui tem-se a impressão de que há uma ambiguidade: primeiro Poros parece corresponder ao lógos no Intelecto. Nesse plano, como forma no Intelecto, o lógos encontra-se concentrado ${ }^{59}$. Depois, na passagem supracitada, Poros está expandido, é difuso. Contudo a ambiguidade é apenas aparente: as duas coisas ocorrem simultaneamente. De fato, é necessário compreender que o lógos não é o puro Intelecto, nem a Alma pura, mas ele depende de ambos. O lógos nun-

58. Não é infrequente o uso do passivo de khéo para descrever o movimento para fora da unidade e dispersão na multiplicidade (WOLTERS, 1972, n. 9.2, 92). Aplötheís é também o estado de Cronos embriagado, no tratado VI, 7 [38] 35, 26 (HADOT, in: PLOTIN, 241).

59. Além disso, é preciso observar que o Intelecto seria degradado e afetado, se ele mesmo estivesse presente na Alma, por isso Plotino precisa postular os lógoi derivados como uma potência que modifica a matéria (ZAMORA, 2000, 188). De fato, é uma característica da matéria sua impassibilidade, da qual derivam as páthè do daimōn Eros. 
ca é excluído do Intelecto nem do Um; todavia, ele se manifesta em ato no nível imediatamente inferior, tornando-se a razão de ser, a unidade que falta naquele nível (COULOUBARITSIS, 1992, passim). Com respeito à relação entre o Intelecto e a Alma, Plotino diz que o lógos é como um raio luminoso (éklampsis) saído simultaneamente do Intelecto e da Alma que o contempla (III, 2 [47] 16, 13-17), isto é, da parte superior da Alma, a qual permanece eternamente voltada para o Intelecto. Portanto, o lógos parece ser produzido pelo encontro do Intelecto e da Alma superior, preenchendo de luz o desejo vago e indeterminado da alma inferior. Tal iluminação produz a multiplicidade de lógoi que, na parte inferior da alma, são como reflexos das formas que a Alma superior contempla no Intelecto (III, 8 [30] 6, 28-29).

Então a sequência do mito parece explicar a difusão do lógos inteligível, através dos lógoi derivados: "Pois o que está no Intelecto está condensado e não lhe provém de outro, mas, para Poros, por estar ébrio, a saturação é algo adventício" (III, 5 [50] 9, 3-5 - trad. Baracat Jr., ligeiramente modificada). A embriaguez de néctar significa que Poros, ao difundir-se, não está mais no estado de concentração que se encontra no Intelecto. Ou seja, retomando a metáfora espacial, o lógos que se difunde pela embriaguez de néctar corresponde àquele que saiu do Intelecto para a Alma. Mas o néctar, bebida divina, é outra figura mítica para o lógos: "Ora, para os deuses, que é o néctar senão o que o divino toma? E o que toma o divino que desceu abaixo do Intelecto é um lógos" (III, 5 [50] 9, 16-18 
- trad. Baracat Jr. $)^{60}$. Essa passagem é bastante confusa, pois faz parecer que o lógos Poros se embriaga de lógos néctar ${ }^{61}$. Para compreender o que isso significa, é necessário voltar à passagem, glosando assim: "Aquilo que lá", isto é, no inteligível, "satura <Poros> de néctar”, é o próprio movimento da Alma que produz nela um lógos, o qual "é o lógos < do Intelecto> que caiu de um princípio superior a um inferior" ${ }^{62}$. Por isso tratase de algo exterior ao Intelecto. Plotino, em suma, parece estar aqui versando sobre o lógos em dois níveis: Poros, em seu estado próprio é o lógos concentrado no Intelecto. O néctar embriagante é o lógos que fluiu para a Alma. Todo esse processo de expansão e fluência do lógos ocorre simultaneamente ao nascimento de Afrodite, a Alma: "Portanto, está na Alma esse lógos o qual, quando se diz que Afrodite nasceu, escorreu do Intelecto para o jardim dele" (III, 5 [50] 9, 6-8 - trad. Baracat Jr. ligeiramente modificada $)^{63}$, isto é, de Zeus.

60. Observe-se que o verbo hypobainō é normalmente usado por Plotino para descrever a descida de um nível hipostático superior para o inferior (DILLON, 1969, 39).

61. Lacrosse $(1995,143)$ nota tal confusão e a justifica, dizendo que, quando se trata de um discurso mítico, as aproximaçóes de uma mesma realidade podem se multiplicar, sem que haja contradiçóes nos termos dessa multiplicação.

62. "Entretanto, aquilo que lá o satura de néctar, que poderia ser senão um lógos que caiu de um princípio superior a um inferior? (III, 5 [50] 9, 5-6 - trad. Baracat Jr., ligeiramente modificada).

63. Observe-se que aqui o verbo esreîn pode ser uma alusão à etimologia de Eros no Crátilo 420 a, que não foi utilizada para Eros. É o lógos néctar que escorre de fora para o jardim, e não o amor. 
O que significa, então, o jardim de Zeus para onde o lógos também escorreu?

E todo jardim é um esplendor e 'um ornato de riqueza ${ }^{64}$. Mas as terras de Zeus são esplendorosas pelo lógos, e seus ornamentos são os esplendores que vieram do próprio Intelecto para a Alma. Ora, que outra coisa haveria de ser o jardim de Zeus senão suas esculturas e esplendores? E que haveriam de ser seus esplendores e adornos senão os lógoi dele escorridos? (III, 5 [50] 9, 8-14 - trad. Baracat Jr. ligeiramente modificada).

Nesse tratado, Zeus representa o Intelecto. Ele possui um jardim para o onde os lógoi, simbolizados pelas riquezas do jardim, escorreram. Não obstante, Plotino diz que o jardim equivale aos esplendores, aos ornamentos, às esculturas e aos adornos que o enriquecem. Estes representam a multiplicidade dos lógoi expandidos. Entre as figuras do jardim e dos esplendores, adornos etc., encontra-se complicação semelhante àquela que havia entre as figuras de Poros e do néctar.

64. Provavelmente é uma referência a Tucídides: kēpion kaì egkallópisma ploútou (apud WOLTERS, 1972, n. 9. 9, 94). Por ser um paralelo extremamente fechado, e porque a palavra egkallópisma é extremamente rara - atestada nos sete séculos que separam Plotino de Tucídides somente uma vez, em Aelius Aristides, o famoso Aticista e "imitador" de Tucídides - parece certo que Plotino esteja aludindo conscientemente a Tucídides, comenta Wolters. 
Para explicar o sentido do jardim e dos objetos no seu interior, é mister lembrar que a expressão lógos designa a manifestação de um princípio e, ao mesmo tempo, sua distribuição, ou seja, o que faz dele a razão de ser de outra coisa (COULOUBARITSIS, 1992, 236). No contexto em questão, significa que o lógos manifesta-se como jardim, e nele se distribui como imagens, outro sentido para o termo agálmata, que compõe a lista de objetos do jardim. Essas imagens seriam os lógoi derivados. Conforme Plotino, os esplendores que estão na Alma, porque estão situados na vida, são designados como jardim de Zeus (III, 5 [50] 9, 35-36). A palavra vida aqui parece indicar os lógoi na alma do mundo, pois são eles que permitem à alma do mundo dar vida aos corpos, fornecendo-lhes uma razão de ser. Observe-se, que por serem múltiplas representações, é possível compreender que os esplendores, adornos etc., equivalem aos lógoi que se difundiram do Intelecto para a alma do mundo, através da Alma, representada pelo jardim. Além disso, Plotino também menciona o jardim em uma passagem posterior, na qual está sintetizando o mito:

Mas, como o lógos é um rebento do Intelecto e uma realidade posterior a ele, e já não é de si mesmo, mas está em outro, diz-se ${ }^{65}$

65. Légetai: pelo contexto da passagem, deduz-se que seja uma alusão a Banquete, 203 b. Wolters (1972, n. 9. 22-23, 97), observa que Plotino aqui reformula o que dissera nas linhas 7-8 do mesmo capítulo: Aphrodité légetai gegonémai que também parece aludir à mesma passagem do Banquete. 
que ele descansava no jardim de Zeus, e que descansava no momento em que se anuncia que Afrodite passou a existir entre as essências (III, 5 [50] 9, 19-23 - trad. Baracat Jr., modificada).

O lógos, Poros, quando sai de si mesmo, isto é, quando sai do estado de concentração em que está no Intelecto, deve se encontrar em alguma coisa, algo diferente dele, simbolizado pelo jardim. Que seria o jardim, senão a Alma? Além disso, que Poros descanse no jardim no momento em que Afrodite nasceu representa, "em certo sentido, a vinda de Poros à Alma, do lógos na indeterminação, que realiza a determinação de Afrodite, isto é, seu nascimento" (HADOT, in: PLOTIN, 1990, 244).

Ainda cabe observar que o lógos é como o elo de ligação de um plano a outro, estando presente em cada nível, ainda que mais degradado quanto mais distante do Um, conforme a lógica interna da processão. Porque liga os planos e está presente em cada qual, Plotino utiliza diferentes figuras para designá-lo, dizendo, finalmente, que "em conjunto, os lógoi são Poros, a euporia e a riqueza de coisas belas já manifestas: isso é o inebriar-se com néctar" (III, 5 [50] 9, 14-16 - trad. Baracat Jr.). E mais ainda, se há certa ambiguidade na linguagem das Enéadas, essa reflete a ligação e a interpenetração dos níveis da realidade.

Outrossim, este é um ótimo exemplo da polivalência alegórica em um dos seus aspectos: uma mesma noção filosófica (lógos) corresponde a diferentes figuras 
míticas. Resumindo o que foi visto a respeito do simbolismo do lógos até aqui, Poros, o néctar e o jardim com seus ornamentos, são diferentes representaçōes do lógos. Poros é o lógos repleto, abundante, eupórico, que fecunda a matéria inteligível. É o lógos de todos os lógoi, diz Plotino (III, 5 [50] 8, 3; 7, 9; 9, 15-16). O néctar simboliza a plenitude que vem do exterior, ou seja, do olhar da Alma. Portanto, é o lógos embriagante, que está saindo de si mesmo, escorrendo na Alma. O jardim, com seus ornamentos, é tanto a Alma, como o lógos já escorrido, o lógos que enriquece a Alma, que é sua razão de ser e que a trespassa, fluindo para a alma do mundo. Por isso ele parece incluir a alma do mundo, o lugar para onde o lógos escorre e de onde a multiplicidade de lógoi vai projetar no sensível as imagens das formas inteligíveis, que são também lógoi ${ }^{66}$.

Zeus é igualmente um bom exemplo do outro aspecto da polivalência alegórica: uma mesma figura mítica representa diferentes noções filosóficas. Zeus é mencionado nas Enéadas representando a Alma ${ }^{67}$. Mas Zeus também é citado, não como figura mítica, mas em referência à escultura homônima de Fídias, exemplificando a capacidade humana de contemplar

66. A identificação do jardim tanto com os lógoi na Alma, como com a própria Alma é autorizada pelo próprio Plotino, que identifica o lógos com a Alma. Esta é o lógos de todas as coisas, o último lógos dos inteligíveis e o primeiro lógos do universo sensível (IV, 3 [27] 12, 17).

67. Em conexão com a figura de Cronos, que representa o Intelecto, no outro mito genealógico das Enéadas. Ver V, 1 [10] 7, 34 -36 e $\mathrm{V}, 8$ [31] 12, 8 ss. E também é associado à figura do demiurgo e à alma do mundo em IV, 4 [28] 6, 8; 10, 13. Em IV, 3 [27] 12, 8 , é pai de Dioniso, que representa a alma do mundo. 
a beleza do inteligível, conforme será visto no último capítulo do presente estudo. No tratado III, 5 [50], Zeus simboliza o Intelecto. Plotino diz que Zeus não pode ser identificado com a Alma, pois esta é Afrodite (III, 5 [50] 8, 5-6). Então propõe examinar o significado de Zeus a partir do Fedro e do Filebo de Platão:

Com efeito, também neste caso devemos conceber Zeus a partir do Fedro de Platão, onde ele diz que esse deus é o 'grande comandante ${ }^{\prime 68}$, apesar de chamá-lo alhures, creio eu, o 'terceiro' ${ }^{69}$; contudo, ele é mais claro no Filebo ${ }^{70}$, quando diz que 'em Zeus há uma alma régia e um intelecto régio" (III, 5 [50] 8, 6-11 - trad. Baracat Jr., ligeiramente modificada).

Plotino considera que a afirmação do Filebo Zeus possui uma Alma e um Intelecto régios - significa que Zeus se situa entre as causas e que deve ser classificado segundo um princípio superior. Isso é confirmado pelos qualificativos que, nos referidos diálogos platônicos, marcam sua excelência: causa, régio e comandante. Por isso, Zeus corresponde ao Intelecto (III, 5 [50] 8, 11-14). Uma vez estabelecido o simbolismo de Zeus, Plotino detém-se na relação entre o Intelecto e a Alma: "Afrodite sendo sua fi-

68. PLATÃO, Fedro, 246 e 4.

69. PLATÃO, Carta II, 312 e 3. Plotino não explica o qualificativo "terceiro" na exegese de Zeus.

70. PLATÃO, Filebo, 30 d 1-2. 
lha, dele nascida e com ele vivendo, será identificada à Alma, sendo chamada Afrodite por causa da beleza, do esplendor, da inocência e da delicadeza da Alma" (III, 5 [50] 8, 14-17 - trad. Baracat Jr., ligeiramente modificada). Beleza é um qualificativo aplicado às realidades inteligíveis e também a Afrodite, pelo que é perfeitamente adequado associar a mais bela das deusas à beleza da Alma. O segundo termo, esplendor, o que é senão uma referência aos lógoi que escorrem do Intelecto, e que correspondem aos esplendores do jardim de Zeus? Inocência, o terceiro termo, nas palavras de Hadot (1990, 237), diz respeito à natureza original da Alma, voltada para o Bem. Se os três primeiros termos apenas descrevem Afrodite, o quarto, abrón, não somente descreve, mas evoca um jogo etimológico ${ }^{71}$ que rompe com a etimologia tradicional, segundo a qual o nome Afrodite deriva de aphrós (HESÍODO, Teogonia, 195; PLATÃO, Crátilo, 406 c). Plotino possivelmente necessita daquela etimologia ao invés desta para poder qualificar com mais precisão a Alma, e, ainda, para introduzir o tema seguinte, acerca da relação entre as realidades metafísicas e os deuses ou as deusas.

Porque, se identificamos os deuses masculinos ao Intelecto e se dizemos que as deusas correspondem às Almas daqueles, dado que com cada intelecto coexiste uma alma, tam-

71. Conforme Wolters (1972, n. 8, 16-17, 90), essa etimologia do nome Afrodite remonta ao grande filólogo alexandrino Dioniso "Chalcenterus", baseado em intercâmbios análogos de ph por b em outras palavras. 
bém por isso Afrodite seria a Alma de Zeus, e mais uma vez testemunham esse raciocínio sacerdotes e teólogos, que identificam Hera a Afrodite e chamam astro de Hera ao astro de Afrodite que há no céu (III, 5 [50] 8, 17-23 - trad. Baracat Jr., ligeiramente modificada).

O princípio exegético, segundo o qual os deuses são ligados ao Intelecto e as deusas à Alma, supõe o princípio filosófico o qual consiste em afirmar que, para cada alma, há um intelecto da alma e que a Alma está unida ao Intelecto. Antes, Plotino havia postulado que Afrodite é filha de Cronos, o Intelecto. Agora, ele considera Zeus o Intelecto e parece fazer de Afrodite a esposa de Zeus, por intermédio do testemunho dos teólogos, que a associam a Hera. Trata-se, mais uma vez, de polivalência, sendo uma mesma noção, Intelecto, representada no tratado por dois deuses, Cronos e Zeus.

\section{A RECOMPOSIÇÃO DO MITO}

Plotino, no último capítulo do tratado, após haver explicado cada elemento do mito de Poros e Penía, menciona a função dos mitos e propõe a sua reconstituição (synaíresis - III, 5 [50] 9, 29). Entre as linhas 30 e 41, ele reagrupa as figuras em torno da noção de Alma. Da linha 42 à linha 57, ele faz o mesmo com respeito a Eros. As figuras que orbitam em redor de Afrodite são Zeus, Poros, o néctar, o jardim e seus adornos. Seguindo, passo a passo, essas linhas finais, eis a reconstituição: 
A Alma / Afrodite está junto ao Intelecto / Zeus (psykhè nōi synoûsa); é produzida por ele. Ela está preenchida de lógos, transbordando euporia (euporías plèrōtheîsa) - isto remete a Poros quando o néctar escorre do alto. De tal modo que podem ver-se nela esplendores, que estão na vida / jardim e imagens de belas coisas / objetos do jardim. Poros dorme do jardim embriagado, isto é, o lógos repleto está estável na Alma. E os deuses festejam, pois estão em grande felicidade, tendo a vida / Alma aparecido e permanecido eternamente entre os entes (que equivalem aos deuses). A noção de eternidade estabelece a passagem da reconstituição do mito do nascimento da Alma para aquele do nascimento de Eros: "E, assim, eternamente, é como veio a existir por necessidade, oriundo do anseio da Alma pelo superior e pelo Bem, e como sempre existiu desde que a Alma existe: Eros" (III, 5 [50] 9, 39-41 trad. Baracat Jr., ligeiramente modificada). Sendo eternos, tanto a Alma, como o amor, não há nascimento a não ser no discurso mítico, como forma de falar. Essa noção, portanto, é necessária também para assegurar a passagem do esquema genealógico para o hierárquico.

O amor é uma realidade mista, porque participa da falta, uma vez que deseja ser preenchido, mas ele não é completamente indigente, pois, se fosse totalmente privado do bem, ele não o procuraria. Assim, o amor, tendo parte no Bem, deseja algo que já possui. Em torno de Eros situam-se as figuras de Poros e de Penía. Eles são seus genitores, pois a privação, o desejo e a memória provocada pelos lógoi encontram-se juntos na Alma. Aqui Plotino associa a memória a Poros, o 
que se justifica, na medida em que, sendo imagem das formas, o lógos é responsável pela memória. Plotino então dedica algumas linhas a Penía e à sua relação com a forma. Porque Penía deseja, ela é uma matéria, enquanto o que se mantém voltado para si mesmo é uma forma. A matéria é como um receptáculo para a forma. Nesse sentido, conclui, Eros é um ser que possui certa relação com a matéria, haja vista que ele é um daimōn gerado pela Alma, na proporção em que ela é privada do Bem, mas deseja o Bem. Por conseguinte, Plotino, ao final do tratado, parece entender que a Alma possui, ao mesmo tempo, o desejo do Bem e a presença do Bem. Graças a essa presença, ela é capaz de rememorar o Bem, percebendo o quanto lhe falta e desejando recebê-lo. Desse desejo, resulta o amor. 
5.

DISCURSOS SOBRE URANO,

CRONOS E ZEUS

Ceguindo a análise dos discursos míticos, cabe es$\checkmark$ tudar as figuras de Urano, Cronos e Zeus, quando aparecem no esquema genealógico. Isso não significa que tal genealogia seja fácil de localizar nos tratados. Há muitas ocorrências esparsas da figura de Zeus. Menos numerosas são as de Cronos e raras as de Urano. Portanto, para localizar os mitos da genealogia divina, foi necessário buscar todas as ocorrências de cada nome. Com efeito, há dois tratados nos quais aparece a genealogia mítica: V, 1 [10] e V, 8 [31]. Essa genealogia é bastante conhecida e remonta a Hesíodo. Em síntese, Urano, o Céu, que havia sido gerado por partenogênese por Gaia, a Terra, deita-se sobre ela e passa a fecundá-la incessantemente. Gaia, portanto, sente-se estufada pela prole de Urano que fica alojada dentro dela. Completamente coberta por Urano, não há espaço no exterior da Terra para onde sair tal prole, que é formada por dezoito filhos, os primeiros deuses indivi- 
dualizados ${ }^{1}$. Porque está túmida e cheia de dores, Gaia dirige-se aos filhos, incitando-os a punir o pai e, assim, sair do interior do ventre materno. Cronos, o mais jovem da raça dos Titãs, incumbe-se da tarefa de mutilar o pai. Urano afasta-se de Gaia, abrindo o tempo e o espaço. Liberados os filhos, Cronos torna-se rei e casase com uma das suas irmãs, Réia, com quem concebe a próxima geração divina. Mas, temendo ser destronado por um filho, Cronos devora cada qual, tão logo nasça. Réia, enfurecida com o marido, esconde o último filho, Zeus, dando em seu lugar uma pedra envolta em cueiros. Zeus, ao crescer, alia-se à mãe contra o pai. Eles lhe dão um emético, e, por esse expediente, Cronos libera os filhos e Zeus assume a liderança do mundo, transferindo-se para o Olimpo (HESÍODO, Teogonia, 126-153).

É sabido que Platão dá como exemplo de grande falsidade (tôn megistōn pseûdos) a passagem da Teogonia de Hesíodo, na qual Urano comete grandes atrocidades e Cronos se vinga. Evidentemente, Platão não narra as atrocidades, nem diz qual foi a vingança. Mas ele adverte que falsidades desse gênero não devem ser contadas, ou, se for necessário falar a respeito, que seja para um pequeno número de ouvintes ${ }^{2}$. É realmen-

1. São doze Titãs, sendo seis machos e seis fêmeas, três Ciclopes e três "cem-braços".

2. [Sócrates] “(...) Mas que Hera foi algemada pelo filho e Hefesto projetado à distância pelo pai, quando queria acudir à mãe, a quem aquele estava a bater, e que houve combate de deuses, quantos Homero forjou, é coisa que não deve aceitar-se na cidade, quer essas histórias tenham sido inventadas com um significado profundo, 
te difícil, conforme observa Brisson (1996, p. 105), não interpretar essa passagem da República como uma condenação irrevocável do mito hesiódico e uma recusa radical da interpretação alegórica desse mito. Por isso é intrigante o fato de Plotino, que tem em tão alta conta o divino Platão, fazer com que a genealogia mítica Urano-Cronos-Zeus corresponda à estrutura UmIntelecto-Alma. Embora não se encontre um tratado consagrado a esse mito, como acontece com o mito de Eros, a genealogia de Urano-Cronos-Zeus dá conta de toda a realidade inteligível, o que a torna um dos principais mitos das Enéadas. Fica, portanto, a pergunta: a presença e a relevância dessa genealogia mítica nas Enéadas não seria um indício de contrassenso com relação a um ponto de doutrina importante na República de Platão? Poder-se-ia responder, com Pépin $(1955,14)$, que os mitos homéricos e hesiódicos são compreendidos através de Platão. Plotino cuida em jamais citar o nome de Hesíodo, nem tampou-

quer não (out' en hyponoíais pepoièménas oúte áneu hyponoiôn). É que quem é novo não é capaz de distinguir o que é alegórico do que não o é (hóti te hypónoia kaì hò mê). Mas a doutrina que aprendeu em tal idade costuma ser indelével e inalterável. Por causa disso, talvez, é que devemos procurar acima de tudo que as primeiras histórias que ouvirem sejam compostas com a maior nobreza possível, orientadas no sentido da virtude" (PLATÃO, República, 378 d 3 - e 3 - trad. Pereira). Essas são efetivamente as três únicas ocorrências do substantivo hypónoia no corpus platônico. Há apenas duas ocorrências do verbo hyponoéo no corpus platônico, em Górgias, 454 b - c; e Leis, 676 c. Sobre essas duas ocorrências, ver Brisson (1994, 153-154). PLATÃO, República, 377 d - 378 a. Trata-se dos versos 154 - 184 da Teogonia de Hesíodo. 
co o de Homero, não se posicionando, assim, como exegeta dos antigos poetas. Mesmo sendo necessário reconhecer a ausência de citaçôes dos nomes dos grandes poetas, nas Enéadas, e ainda que eventualmente se descubram doutrinas platônicas sob o véu do mito ${ }^{3}$, resta a questão acerca da escolha desse mito, exatamente esse, chamado de grande mentira por Platão. Bréhier (in: PLOTIN, 1989, n. 1, 25) considerava que a interpretação do mito da tríade divina era comum à época de Plotino e que seus ouvintes a conheciam, o que justificaria o modo fragmentado com que Plotino o menciona. Talvez Bréhier estivesse pensando na interpretação de Cornuto, por exemplo, mas o fato é que ele não comprova sua hipótese. É sabido, entretanto, que a defesa de Homero seguida por séculos de exegese alegórica dos antigos mitos, atenuou a sua violência.

Para Brisson (1996, 105 ss.), em muitas ocasiōes Plotino considera os mitos, não por intermédio de Platão, mas diretamente a partir de Homero e Hesíodo, apresentando uma solução engenhosa, mas bastante plausível que, não obstante, articula a genealogia mítica com uma interpretação da mesma passagem detratora dos mitos em Platão. Ele nota que naquele trecho da República há uma alusão aos mistérios, evidentemente irônica, a qual se constata mediante os termos sigâsthai e di'aporrếtōn, além da menção ao sacrifício de um porco. Essa alusão foi tomada literal-

3. Quanto a esse ponto, se deve paliar a atitude de Pépin: o mito da tríade divina revela o esquema hierárquico da realidade tal como Plotino o compreende, mais do que dogmas platônicos. 
mente por certo número de platônicos que desejaram incluir tal mito ao longo da iniciação filosófica. Esse teria sido, por exemplo, o significado de uma passagem de Numênio (frag. 21 des Places = Proclo, In Timaeum, I, 303, 27-304 Diehl), na qual ele classifica os três deuses como avô, pai e filho ${ }^{4}$. Então, pelo viés das exegeses mistéricas dos mitos que, aliás, se fundamentam em interpretações dos diálogos de Platão, Plotino teria assimilado o mito hesiódico às três realidades, fazendo da "grande mentira" um dos mais importantes discursos míticos das Enéadas.

Cabe ainda notar que, se Platão, na República, acentua os traços de violência e imoralidade da narrativa de Hesíodo, na qual abundam combates, sangue, fúria, Plotino, em sua exegese, faz desaparecer qualquer traço de catástrofe. Talvez porque ele aja com benevolência em relação a esse mito e aos outros que menciona nas Enéadas, tal como sugere que se faça com Platão e os Antigos e bem-aventurados filósofos 5 .

4. Segundo Porfírio, Plotino lia os comentários de Numênio nas aulas e a influência deste deve ter sido tão grande, que Plotino foi acusado de plágio, tendo o discípulo Amélio escrito uma espécie de defesa na qual mostrava as diferenças entre um e outro (PORFÍRIO. Vida de Plotino, 14; 17 - trad. Ullmann). Sobre a relação entre Numênio e Plotino pode-se consultar ARMSTRONG (1940, 7-9) e DODDS (1960, 1-61).

5. Plotino usa a expressão "com benevolência" (eumenôs) para designar como se deve portar o exegeta em relação a Platão e aos Antigos, em oposição ao modo conforme os interpretam os gnósticos, que os desrespeitam e os desacreditam com o fito de justificar sua própria doutrina. Ao invés disso, deveriam interpretar com benevolência as doutrinas de Platão e dos Antigos, ou ainda Gregos, como a eles se refere aqui Plotino (II, 9 [33] 6, 26-54). 
Por outro lado, essa isenção de desastres e catástrofes, envolvendo as figuras de Urano, Cronos e Zeus, poderia ser explicada pelo fato de esse mito figurar no contexto do ataque de Plotino aos gnósticos. Essa hipótese foi esboçada por Hadot (1981b, p. 124-137), considerando que III, 8 [30]; V, 8 [31], V, 5 [32] e II, 9 [33] formariam, na sua origem, um grande tratado contra os gnósticos ${ }^{6}$. Com efeito, observa-se que nesse conjunto de tratados há alusões à tríade divina, especialmente em $\mathrm{V}, 8$, no qual o mito é mais desenvolvido que em outros tratados. De modo geral, podese dizer que dois aspectos da metafísica gnóstica são alvos de críticas passíveis de ser ilustradas pelo mito da genealogia divina: o primeiro corresponde à proliferação excessiva de realidades inteligíveis ${ }^{7}$. O segundo, ao modo como o mundo sensível é formado, pois os gnósticos parecem pensar que este mundo nasceu no tempo, em consequência da queda de uma realidade inteligível. Através do mito de Urano, Cronos e Zeus, Plotino não somente mostra que as realidades são três, mas igualmente faz ver que acontecimentos, os quais

6. O primeiro a sugerir que tais tratados formavam originariamente um todo foi Harder, em 1936. A maioria dos comentadores aceita tal teoria. Para a história das publicaçóes acerca da existência do Grande Tratado, sejam aquelas que a defendem ou a refutam, ver Dufour (in: PLOTIN, 2006). Sendo o escopo do presente estudo apenas apresentar o mito da genealogia divina, e, no contexto, a interpretação de Hadot, não será possível discutir acerca da existência do Grande Tratado.

7. Por exemplo, o Pleroma de Ptolomeu contém 30 éons, ao passo que certos gnósticos contavam 256 e até mais realidades. (DUFOUR, in: PLOTIN, 2006, 192). 
a linguagem mítica exprime no tempo, são, na verdade, simultâneos. Além disso, não havendo traços de catástrofe, Plotino subtrai do processo de formação do mundo sensível paixões, ansiedade, dependência de uma atividade calculada e raciocinada. Em suma, o mito mostra que o mundo sensível reflete necessariamente a beleza do inteligível, que flui facilmente e naturalmente na Alma, como parte de sua eterna contemplação do Intelecto (HADOT, 1981b, 134).

Finalmente, Lamberton (1986, 16), de forma indireta, oferece outra pista para compreender a presença desse mito na obra de Plotino. O estudioso mostra que na história da leitura de Homero, a crítica platônica da República situa-se acima de todas as outras críticas a Homero, tanto por sua devastadora condenação ao poeta, como por sua influência nos leitores subsequentes. Essa crítica é central para Heráclito, o alegorista, que insiste na superioridade de Homero, e tenta condenar Platão. Igualmente é central para Proclo, que pretende conciliar o poeta e o filósofo. Mas as tentativas de reconciliação remontam ao século II d.C., nas figuras de Numênio e de um certo Télefos de Pérgamo ${ }^{8}$. Essas tentativas de reconciliação assumiram uma importância crescente nos meios platônicos, porquanto certos autores desejavam situar Homero e outros teólogos ao lado de Platão no cânone dos que entreviram a verdade. Essa tendência é crescente nos tempos do

8. Este parece ter sido um gramático que viveu no tempo de Adriano e foi instrutor de Verus. Sobre ele não importa tecer mais quaisquer comentários, pois não há indícios que o liguem a Plotino. 
Império romano, em parte devido à necessidade de oferecer uma escritura com autoridade capaz de suportar as comparaçóes cada vez mais pesadas com as Escrituras da tradição cristāâ. Os neoplatônicos, de modo geral, quiseram proteger a religião tradicional contra a invasão da religião cristã, pois acreditavam que o culto dos deuses estava ligado à ação da alma do mundo, conservadora do universo. Além disso, para eles, mitos e ritos pagãos eram considerados um platonismo de uso popular, e mais ainda, uma física oculta (HADOT, 2004, 89-90) ${ }^{10}$. No que concerne a Numênio, dos cerca de sessenta fragmentos das suas obras, que chegaram aos dias de hoje, há um, conservado por Eusébio de Cesaréia ${ }^{11}$, que permite divisar essa tenta-

9. Embora essa hipótese seja muito interessante, nos limites do presente estudo não é possível aprofundá-la. A menção a ela tem por escopo unicamente situar o nome de Numênio em relação às tentativas de conciliação entre Platão e Homero. Entrementes, cabe observar que Numênio alude, não somente a Platão, Pitágoras e Homero, mas também à sabedoria dos egípcios, persas e judeus. Ele talvez esteja na raiz dessa sobrevalorização dos mitos de Homero e Hesíodo, que se torna clara em Jâmblico e seus discípulos, como o imperador Juliano e, mais tarde, em Proclo.

10. É preciso deixar claro que Plotino não parece tematizar esse assunto, mas considerando tais ideias em voga por sua época, não é impossível que estivessem de certo modo na base do seu uso de mitos. Plotino é, de fato, um pensador ligado ao mundo grego pagão.

11. "Se, depois de ter-se proposto escrever sobre a teologia dos Atenienses, Platão se pusesse a vilipendiá-los, a reprová-los por conter lutas intestinas, incestos entre pais e filhos e festins onde estes são devorados, a contar suas vinganças contra os pais por esses crimes, ou aquelas dos irmãos contra os irmãos e outros crimes semelhantes, se então Platão, tomando essas narrativas, as tivesse reprovado abertamente, ele teria, me parece, dado aos Atenienses 
tiva de acordo entre Homero e Platão, por sinal fundamentada em certa leitura de diálogos de Platão, o que, portanto a legitimaria como exegese de passagens dos textos do fundador da Academia. Numênio parece ter-se dedicado a mostrar tal acordo, especialmente no que tange ao problema do destino das almas após a morte (BRISSON, 1996, 102). Assim, por exemplo, ele teria assimilado o mito de Er, do final da República, à passagem da Odisséia acerca da gruta das Ninfas situada em Ítaca (NUMÊNIO, frag. 30 des Places = PORFÍRIO, Sobre a gruta das Ninfas, 10).

Ainda que em Plotino não se encontre nenhuma evidência de reconciliação entre Homero e Platão, um vestígio poderia ser entrevisto justamente no uso do mito da tríade divina. Que Plotino tenha recebido, de certo modo, de Numênio essas tentativas de conciliação como sendo válidas, é impossível provar. Porém, confiando no testemunho de Porfírio, é indubitável que Plotino leu Numênio e que essas leituras estão nas entrelinhas dos tratados das Enéadas. Assim sendo, nada há de surpreendente que a influência de Numênio se tenha estendido ao campo da interpretação de mitos (BRISSON, 1996, 103). Em suma, parece que as di-

a ocasião de reiterar seu crime e de matá-lo, como a Sócrates. Pois de fato, ele teria < preferido> não viver a dizer a verdade, como, por outro lado, ele via um meio de viver dizendo-a sem risco, ele pôs na personagem dos Atenienses esse Eutífron fanfarrão e estúpido, medíocre teólogo, se ele o foi, com Sócrates em pessoa diante dele, no estilo original que peculiarmente servia a confundir todos os que o frequentavam" (NUMÊNIO, frag. 23 des Places = EUSÉBIO, Preparação Evangélica, XIII 4, 4-5). 
versas hipóteses aventadas podem ser válidas, haja vista que não se excluem. Revendo-as, é possível realmente que esses mitos tivessem uma interpretação conhecida à época, como, por exemplo, a de Cornuto; que eles já tivessem sido purgados da violência pelos exegetas de Homero, como é o caso de Heráclito, o alegorista ${ }^{12}$; que Plotino visse neles um modo de ilustrar conceitos filosóficos através de antigas histórias; que ele tenha recebido esse mito de algum autor platônico, como $\mathrm{Nu}$ mênio, o qual parece ter visto nele uma alusão aos mistérios e, portanto, o incluiu no rol dos textos passíveis de estimular a iniciação filosófica; que Plotino quisesse combater elementos do gnosticismo, com a autoridade de textos canônicos do mundo grego; que, finalmente, ele tenha recebido um Homero reconciliado com Platão, de novo através de Numênio. Assim, Plotino teria, de bom grado, feito da trilogia divina um dos mais importantes mitos das Enéadas, sem ter provavelmente a menor intenção de criticar de modo sub-reptício Platão, ou de posicionar-se contra o divino mestre da Academia. Que Plotino não tinha em mente posicionar-se contra Platão pode-se depreender das alusões a diálogos platônicos, como o Crátilo, por exemplo, que funda-

12. Heráclito, o autor das Alegorias de Homero, "não o obscuro, mas o que se propôs tornar críveis as histórias incríveis" (EUSTATIO, 1504, 55 apud BUFFIÈRE, in: HERACLITE. Allégories d'Homère, p. IX). Heráclito, certas vezes alcunhado "Pôntico", não deve ser confundido com Heráclido Pôntico, discípulo de Platão. Alcunhá-lo aqui "o alegorista" é apenas uma forma de introduzir o personagem, estabelecendo uma diferença entre os diversos Heráclitos da Antiguidade de quem chegaram textos ou fragmentos aos dias de hoje. 
mentam certos aspectos de sua hermenêutica do mito hesiódico. Mas diante daquela conhecida passagem da República, parece claro que o exegeta, mesmo sem tencionar, marchou em sentido contrário: não somente narrou o mito, como ainda o interpretou.

Para além dos tratados analisados a seguir, percebe-se que as figuras de Urano, Cronos e Zeus são mencionadas em outros passos da obra plotiniana, encontrando-se referências a elas, associadas às três hipóstases em tratados iniciais ${ }^{13}$, médios ${ }^{14}$ e tardios ${ }^{15}$. Isso demonstra que tal mito não está a serviço somente da crítica aos gnósticos: de fato a teogonia hesiódica permite a Plotino apresentar a estrutura da realidade. Entretanto, apenas duas menções são pontuadas pelas relações de parentesco entre as figuras (V, 1 [10] 7, 30-35 e V, 8 [31] 12-13), as quais serão examinadas agora.

\section{A GENEALOGIA EM V, 1 [10] 7, 30-35}

Em V, 1 [10] 7, Plotino está versando acerca do Intelecto, quando intervém a parte mítica, introduzida pela frase "desta linhagem provém o Intelecto"

13. Cronos e Zeus em V, 1 [10] 7; Zeus em VI, 9 [9] 7, 24.

14. Zeus é citado em IV, 3 [27] 12; IV, 4 [28]; V, 8 [31].

15. Cronos e Zeus são mencionados em II, 3 [52] 12. Os três figuram em III, 5 [50]; embora nesse tratado a figura de Zeus mude de status, passando a figurar o Intelecto, Urano e Cronos seguem simbolizando o Um e o Intelecto, respectivamente. Não obstante, na maior parte dos casos em que é citado, Zeus representa a Alma. Parece haver apenas uma citação do nome de Urano, em III, 5 [50] 2, 15. Nos tratados em que aparece a genealogia da tríade divina, ainda que não se encontre seu nome explicitamente, se pode subentender pelo contexto de que dele se trata. 
(V, 1 [10] 7, 27), a qual evoca uma estrutura de parentesco. Plotino apresenta a relação entre descendentes e ascendentes em termos metafísicos, dizendo que o Intelecto nasceu do primeiro princípio e, uma vez nascido, gerou consigo todos os entes que vêm com ele, toda a beleza das formas, todos os deuses inteligíveis (V, 1 [10] 7, 27-30). Após o quê, detalha certo aspecto em termos míticos:

$<\mathrm{O}$ Intelecto> está repleto de entes que pro-
duziu, como se os tivesse engolido para tê-
los novamente em si mesmo e não permitir
que tombem na matéria e sejam alimentados
por Réia, como exprimem de modo velado
os mistérios e os mitos que falam acerca dos
deuses, dizendo que Cronos, o deus mais sá-
bio, vem antes de Zeus, e que ele retoma em
si mesmo o que produz, tornando-se repleto e
Intelecto em saciedade $(\mathrm{V}, 1[10] 7,30-35)^{16}$.

Com efeito, o mito de Cronos devorando os filhos alude ao Intelecto que contém em si todos os inteligíveis. As formas inteligíveis contidas no Intelecto não escorrem elas próprias ao corpo, mantendo-se longe da matéria, simbolizada por Réia, em oposição a Cronos. A metáfora da deusa que alimenta os filhos representa

16. A tradução dessa passagem segue a leitura de Atkinson (1983, 177 ss.), que considera o sujeito da construção como sendo o Intelecto. Além disso, Atkinson nota o uso dos hesiódicos katapinein (Teogonia, 459) e traphêvai (Teogonia, 480), além da menção à esposa de Cronos, Réia. 
igualmente uma oposição à saciedade de Cronos, pois as formas inteligíveis que têm contato com a matéria não são tão perfeitas quanto aquelas que permanecem no inteligível, tanto o saciando, como saciadas por ele, conforme fica subentendido. A propósito, o termo Réia aqui pode ter um duplo sentido: é a esposa de Cronos, mas também conserva a interpretação heraclitiana do fluxo e da instabilidade. Tal interpretação funda-se no Crátilo, quando Sócrates estabelece uma comparação entre Heráclito e Homero, na qual o nome de Réia é associado ao fluir (PLATÃO, Crátilo, 402 a-b) ${ }^{17}$. Plotino, em geral, parece opor a instabilidade, representada pela fluidez da matéria, à estabilidade do Intelecto. Consoante o que ele afirmara algumas linhas antes, o repouso é característico dos inteligíveis, que não devem, por assim dizer, flutuar na indeterminação (en aoristōi hoîon aiōreîsthai - V, 1 [10] 7, 23-25. Permanecendo com os inteligíveis retidos em si, o Intelecto é saciado. A expressão noûs en kórōi, Intelecto em saciedade, alude a um passo anterior do tratado, onde Plotino considera Cronos o deus que é saciedade (kóros) e Intelecto (nôेs - V, 1 [10] 4, 9-10). Embora a etimologia Cronos kóros encontre-se no Crátilo, kóros significa nesse diálogo "puro, sem mistura" (PLATÃO, Crátilo, 396 b). Por sua vez, a relação entre kóros e saciedade parece remontar a uma etimologia estóica conservada por Cícero (Sobre a natureza dos deuses, II, 25, 64): saturnus autem est

17. A matéria em Plotino é representada por metáforas líquidas, como a das águas, conforme pode ser visto no mito do anônimo. 
appellatus, quod saturetur ${ }^{18}$. A noção de que Cronos é o deus mais sábio pode ser uma alusão ao Crátilo "é razoável que Zeus seja filho de um grande intelecto" (PLATÃO, Crátilo, 396 b 4).

Assim, Plotino afirma que, uma vez estando repleto, Cronos engendra Zeus. Plotino então estabelece um paralelo entre a saciedade do Intelecto e sua perfeição ${ }^{19}$, a fim de mostrar que uma potência tão grande como o Intelecto não pode permanecer sem descendência $(V, 1[10] 7,38)$. Trata-se de um princípio fundamental da processão, segundo o qual "todas as coisas, uma vez que atingem a perfeição, engendram" $(\mathrm{V}, 1[10] 6,38)^{20}$. Desse princípio decorre uma diferença necessária entre o que produz e o produzido: este é inferior àquele. Plotino diz que a Alma é uma

18. Além disso, é interessante observar que, segundo o alegorista de nuança estóica, Cornuto (século I d.C.), Urano representa o céu, Cronos o tempo, Réia, que etimologicamente quer dizer "fluir", simboliza a terra. Seu casamento com Cronos representa a união do tempo e do mundo. Dessa união tudo surge mas, em alusão ao episódio em que Cronos devora seus filhos, o tempo devora tudo, com exceção do que é imortal, o princípio da vida, simbolizado por Zeus. O mito da genealogia divina parece ter feito fortuna entre os estóicos.

19. Isso fica claro na construção da frase: "Conta-se então que, uma vez saciado, ele engendra Zeus; e pois o Intelecto engendra a Alma, sendo o Intelecto perfeito" (V, 1 [10] 7, 35-37).

20. O mesmo princípio é enunciado em outros tratados das Enéadas, como, por exemplo, em V, 4 [2] 1, 20 ss., onde Plotino apresenta como que um resumo: o Intelecto provém do Um, que é a primeira potência, é mais perfeito que todos, e por isso todas as demais potências o imitam na medida das suas possibilidades. Assim, quando alcançam sua perfeição, engendram. 
imagem (eídōlon) do Intelecto, é indeterminada (aóristos), sendo que sua determinação vem da enformação $(V, 1[10] 7,40)$. No capítulo 3, Plotino também afirmara que a Alma é uma imagem (eikốn) do Intelecto $(\mathrm{V}, 1[10] 3,7)$. Aqui parece tratar-se da relação icônica entre a imagem e o modelo, muito embora a Alma e o Intelecto possuam tanto uma relação icônica, como uma relação mimética. Na relação icônica, como foi visto, a imagem é um efeito. A noção de que o produto é definido pelo produtor é mencionada em dois momentos anteriores do tratado, uma vez em referência à definição da Alma pelo Intelecto $(\mathrm{V}, 1$ [10] 3, 13-14), e outra concernente à definição dos números pelo Um, isto é, do Intelecto pelo Um (V, 1 [10] 5, 6-19). Portanto, significa que cada termo posterior é indeterminado apenas em relação ao anterior, e não completamente indeterminado, pois essa é uma característica da matéria. Plotino então conclui afirmando: "O produto do Intelecto é um lógos e uma realidade, é a razão discursiva" $(\mathrm{V}, 1[10] 7,42-43)^{21}$. Para compreender essa frase, é necessário mais uma vez voltar ao capítulo 3 do tratado, onde temas análogos haviam sido desenvolvidos, através de um discurso anagógico, no qual Plotino quer conduzir a alma humana a compreender suas funçôes intelectivas e a perceber sua depen-

21. Cabe recordar que o termo hipóstase é empregado por Plotino em um sentido amplo, designando a existência ou subsistência de uma realidade independente. Foi Porfírio que o utilizou designando tecnicamente as três realidades superiores, o Um, o Intelecto e a Alma (FRONTEROTTA, in: PLOTIN, n. 1, 2003, 172). 
dência em relação ao próprio Intelecto (BRUNNER, 1973, 145) ${ }^{22}$. Isso é possível, porquanto a Alma é o lógos do Intelecto, ela é toda a atividade, toda a vida que ele projeta para dar existência ao resto. Plotino explica isso mediante o exemplo do fogo, no qual há o calor que permanece nele e o calor que ele fornece (ARISTÓTELES, Metafisica, A 1, 993 b 25). Do mesmo modo, no Intelecto há uma atividade que permanece nele, e uma que escorre para fora dele, que se exterioriza, adquirindo uma existência independente (V, 1 [10] 3, 8-12). Esta é a Alma. Voltando ao capítulo 7 do tratado, Zeus, que vem logo após o Intelecto, pode ser identificado à Alma. Como foi visto até aqui, a Alma provém do Intelecto e se mantém ligada a ele.

22. Nesse capítulo anagógico, conforme observa Brunner $(1973,145$ ss.), Plotino recorre a uma linguagem multiforme, na qual encontram-se tanto a linguagem técnica inspirada em Aristóteles (notadamente quando Plotino explica que a Alma é enérgeia do Intelecto), quanto uma profusão de imagens, tais como o fogo (linhas 10-11), a filha alimentada pelo pai (linhas 12-15), o olhar (linhas 15-17). Brunner considera que tais imagens não se destinam a florear o estilo; elas expressam melhor que o conceito a relação dinâmica existente entre as realidades inteligíveis, as semelhanças e diferenças entre elas. Além disso, as imagens oferecem isso tudo junto, como em uma intuição intelectual, que pode ser, em seguida, imperfeitamente desenvolvida em raciocínios. Portanto, as imagens têm uma eficácia no que tange à elevação da alma acima dela mesma, em direção ao Intelecto. No âmbito deste estudo, entretanto, não serão analisadas as imagens e os argumentos em totalidade, mas somente aqueles que interessam à compreensão da passagem relativa a Cronos e Zeus que se está estudando. 
É esse o sentido das metáforas as quais Plotino usa ao final do capítulo em questão: a Alma como que orbita em torno do Intelecto (perì noûn kinoúmenon); é como uma luz phôs que emana do Intelecto; é como um traço (ikhnos) que ele deixa de si (V, 1 [10] 7, 43-44) ${ }^{23}$. Por outro lado, a Alma toca naquilo que vem depois dela, ou seja, ela engendra seres que são inferiores a ela, pois com a Alma terminam as coisas divinas (V, 1 [10] 7, 45-fim).

\section{A GENEALOGIA EM V, 8 [31], 12-13}

Em V, 8 [31], o mito aparece em um contexto distinto do anterior e mais amplamente desenvolvido: no tratado V, 1 [10], o mito ocupa 5 linhas, ao passo que no tratado ora estudado, ocupa dois capítulos. Quanto ao contexto, neste tratado Plotino mostra todo o percurso cognitivo da alma para atingir a visão do universo inteligível, descrevendo-o como uma identidade de ser, pensamento e intelecto, e também como a essência verdadeira e fundadora da Alma (SOARES, 2003, 111). Uma particularidade desse tratado é seu tom lírico. Com efeito, como observa Laurent (in: PLOTIN, 2006, 80), "Plotino tenta aqui de algum modo o impossível: dizer a perfeição do mundo inteligível, enquanto estamos no sensível imperfeito e mutável, dizer o eterno pelo temporal,

23. Plotino usa para a Alma a metáfora da luz que orbita em torno ao Intelecto em V, 3 [49] 9, 15-17. A luz que provém do Intelecto é análoga à que emana do Um $(\mathrm{V}, 1[10] 6,28-30)$. Traço (ikhnos) parece aludir a eidōlon (linha 40). Nas Enéadas o termo íkhnos aparece pela primeira vez nesse tratado (BRUNNER, 1973, 166). 
fazer compreender a verdade por frases e proposições que não existem lá”. Essa ideia pode ser fundamentada em uma afirmação do próprio Plotino, ao final do capítulo 12: "De fato, dada a necessidade de querer explicar, é preciso usar estas palavras" (V, 8 [31] 12, 24-25 - trad. Soares). Ainda segundo Laurent, com esse escopo todos os meios são bons, sejam eles um convite à introspecção (capítulo 2), uma referência a Homero (4), ou ainda, a interpretação do mito hesiódico de Urano, Cronos e Zeus (12-13). Esta é, aliás, uma das tarefas do filósofo, que não apenas deve construir raciocínios, argumentos demonstrativos, ou ainda convidar à virtude, mas também deve testemunhar uma experiência vivida, anunciando que a alma do sábio pôde ver a beleza inteligível.

Assim, o mito surge na voz de um narrador fictício que viu a si mesmo e, através de si mesmo, viu o Intelecto ${ }^{24}$. Tal narrador se expressa de acordo com o modo da poesia inspirada: ele anuncia (apangélei - V, 8 [31] 12, 3) ${ }^{25}$, como em um poema teogônico, as geraçôes divinas. Eis como começa a fala do narrador fictício:

Anuncia ter visto um deus que dá à luz uma bela prole e que, na verdade, gera toda ela em si mesmo e que tem em si o fruto do par-

24. Todo o capítulo 11 dedica-se a descrever o estado da alma que se vê identificada ao Intelecto. Supostamente, o narrador do capítulo 12 é alguém que viveu esse estado.

25. O verbo apangéllō significa em sentido geral: trazer uma resposta, anunciar, mas também, por extensão, revelar, fazer conhecer, descrever, traduzir, tendo, portanto, relação com a noção de indicar. 
to desprovido de dor. De fato, deleitado por aqueles que gerava e regozijado pelos filhos, retém tudo em si, alegrando-se do esplendor dele e dos filhos (V, 8 [31] 12, 2-7 - trad. Soares, ligeiramente modificada).

Embora ele não mencione o nome do deus, não é difícil deduzir que esteja se referindo a Cronos, até porque, na sequência da passagem, conforme será visto, ele diz textualmente que este deus gerou Zeus. Mas quanto a essa parte, nota-se que versa acerca do episódio no qual Cronos ingere os filhos. No poema de Hesíodo, Cronos devora os filhos, porque teme que eles o destronem, como ele fez com seu próprio pai, ou ainda porque sente ódio deles. Para Plotino, que, ao narrar e interpretar mitos dá mostras de grande liberdade em relação às formas tradicionais dos mesmos, Cronos, que representa o Intelecto, retém os filhos no seu interior por amor (HADOT, 1981b, 128) ${ }^{26}$. Ele parece emocionado com a beleza da sua prole, significando que se alegra com a beleza dos inteligíveis. "Mas ele, não obstante <seus filhos> sejam belos e mais belos aqueles que permaneceram em seu interior, <um> único entre os outros filhos, o jovem Zeus, aparece no exterior" (V, 8 [31] 12, 7-9 - trad. Soares). Aqui novamente Plotino oblitera um fato do mito hesiódico: é Réia quem esconde Zeus, impedindo que Cronos

26. Hadot (1981b, 130) nota que Cronos governa sobre si mesmo, pois sua prole permanece interior a ele, diferente de Zeus e de Urano, cuja prole é exterior. 
o engula. Mas nas Enéadas o próprio Cronos parece deixar que Zeus apareça no exterior. Outro detalhe que merece ser observado é o fato de os filhos que permanecem no interior de Cronos serem mais belos que Zeus. Parece significar que as formas inteligíveis, que compóem o próprio Intelecto, são superiores em beleza à Alma, que se exterioriza, tornando-se uma realidade outra que o Intelecto. É nesse ponto do mito que Plotino vai mostrar que o filho é imagem do pai:

Dele, ainda que seja o último filho, é possível ver como uma imagem daquele pai, quanto é grande aquele pai e os irmãos que permaneceram nele. Mas ele diz que não foi em vão para longe do pai: pois é necessário que exista um universo diferente daquele, um universo que nasceu belo enquanto imagem do belo e do ser. Decerto a imagem imita o modelo em tudo. Possui, na verdade, seja a vida e isto que pertence ao ser enquanto imitação, seja o ser bela enquanto vem dali. Mas possui também a eternidade daquele enquanto imagem; senão o modelo terá algumas vezes uma imagem, outras vezes não, sendo a imagem uma criação da arte. Mas cada imagem por natureza existe enquanto perdura o modelo (V, 8 [31] 12, 9-20 - trad. Soares).

Nessa passagem Plotino evidencia que Zeus se afasta do pai, porque necessariamente deve existir um universo diferente do Intelecto, um universo que seja 
belo, porquanto é imagem do pai. Esse ponto introduz provavelmente a polêmica contra os gnósticos, que consideram o mundo feio e vil, pois foi produzido por um demiurgo mau (II, 9 [33] 4-5). Também fica claro, nessa passagem, que o mundo é eterno, na medida em que é imagem do modelo eterno. $\mathrm{O}$ argumento estabelece, de certo modo, uma relação de dependência entre o modelo e a imagem, pois é necessário que exista a imagem enquanto existir o modelo. Isso também alude à não-temporalidade das realidades metafísicas e à simultaneidade das ações narradas: Cronos retém os filhos, e Zeus se exterioriza ao mesmo tempo, pois, tanto o pai-modelo como o filho-imagem são eternos. $\mathrm{Na}$ sequência do texto, Plotino parece deixar mais claro que está querelando com certos adversários, e que está tratando da relação entre o mundo inteligível e o sensível, sendo este imagem daquele ${ }^{27}$. Finalmente, outro acontecimento mítico é aludido por Plotino: o agrilhoamento de Cronos (HOMERO, Iliada, XIV, 203-204).

O deus então que está acorrentado para permanecer do mesmo modo e que cedeu ao filho a guia deste todo - pois para ele, não estaria conforme à sua condição abandonar

27. "Por isso não estão certos aqueles que destroem $<0$ universo sensível>, se o inteligível perdura, e o geram, como se o criador tivesse deliberado criá-lo, visto que não querem compreender qual seja a natureza de uma tal criação, nem sabem que até o momento em que aquele esplende, as outras coisas nunca podem esvair, mas, a partir do momento em que este existe, também estas coisas existem. Mas o <universo inteligível> sempre foi e será" (V, 8 [31] 12, 20-25 - trad. Soares, ligeiramente modificada). 


\begin{abstract}
o governo de lá e perseguir um governo mais recente e posterior a ele, como se estivesse saciado de coisas belas - tendo deixado estas coisas, colocou seu pai na natureza que lhe é própria e se estende até ele em direção ao alto (V, 8 [31] 13, 1-6 - trad. Soares).
\end{abstract}

Se na épica Cronos é preso por Zeus, para Plotino, ele próprio se põe nessa situação. Isso porque o Intelecto fixa seus próprios limites e, ao mesmo tempo, estende seu poder para a Alma. Esta então produz um novo reino, o mundo sensível, que não é tangido pelo Intelecto. Plotino assevera que Cronos não abandonaria o governo de lá por um governo mais recente e posterior. A bem da verdade, não se deve entender como temporalmente mais novo, mas sim hierarquicamente inferior. $\mathrm{O}$ que está de acordo com a noção de imagem e modelo, desenvolvida pouco antes. Em suma, o mundo sensível é considerado inferior ao inteligível, ao ser caracterizado como imagem deste. A inferioridade hierárquica é também representada miticamente pela posteridade cronológica. Além disso, ao mesmo tempo que se separa do filho, o deus também se situa em relação ao pai, demarcando um limite para o pai e se diferenciando dele. Embora não mencione o nome do pai de Cronos, a expressão pròs tò ánō parece aludir à etimologia do nome Urano do Crátilo 396 c 1 , horôsa tà áno ${ }^{-28}$. A sequência da narrativa sugere o episódio da emasculação de Urano:

28. Esta etimologia foi mencionada na análise da genealogia de Eros. 
Mas, por outro lado, estabeleceu que as coisas que começam do filho devam existir depois dele, de modo a vir a ser entre os dois, por causa da alteridade (eterótēti) produzida pelo corte em direção ao alto e pelo vínculo que o retém distante disto que vem depois dele em direção ao baixo, estando entre um pai melhor e um filho pior (V, 8 [31] 13, 6-11 - trad. Soares).

A noção de alteridade é bastante importante para compreender a passagem ${ }^{29}$. Embora o Intelecto permaneça ao lado do Um, ele se diferencia da unidade primeira multiplicando-se nas formas inteligíveis. Nesse caso, no registro da filosofia, a alteridade está em conformidade com a divisão dialética (LAURENT, in: PLOTIN, 2006, n. 200 e 201, 127). Outrossim, a alteridade corresponde, no mito, à castração de Urano, ao corte em direção ao alto. Mas Plotino cuida em preservar Cronos vinculado a Urano, notando que tal vínculo o mantém a certa distância de Zeus. Portanto, conforme a análise de Hadot (1981b, 129), o retorno do Intelecto em direção ao Um é o que verdadeiramente Plotino prefigura, através da mutilação de Urano. O Intelecto, quando surge, contempla o Um e, ao fazê-lo, recebe um limite tornando-se diferenciado (VI, 7 [38] 17), mas mantendo-se por meio da

29. Trata-se de um dos cinco gêneros supremos do Sofista de Platão, que, para Plotino, são constitutivos do mundo inteligível. Ver VI, 2 [43] 15, o estudo de BRISSON (1991, 449-473) e também o livro de MONTET (1996). 
eterna contemplação unido ao Um. Não obstante, cabe ainda notar que Plotino situa o Intelecto entre a Alma e o Um, como um intermediário entre um pai melhor e um filho pior.

Dessarte, no tratado V, 8 [31], o mito da genealogia divina parece centrar-se em Cronos, mais do que em Zeus ou Urano ${ }^{30}$. Com efeito, os três episódios aludidos por Plotino, o da deglutição da prole, o do acorrentamento e, finalmente, o da castração, têm por agente Cronos. Ele engole os filhos, significando que o Intelecto retém as formas inteligíveis em si, fazendo com que sejam idênticas a ele. Ele também libera um único filho, Zeus, o qual representa a Alma, para que governe um mundo diferente, o sensível, que é imagem do mundo inteligível. Com isso, o Intelecto fixa seus próprios limites, o que é representado pelo agrilhoamento de Cronos. O mundo inteligível é interior ao Intelecto; portanto ele governa a si mesmo. O mundo sensível é exterior à Alma, que efetivamente governa um mundo composto de forma e matéria. Por isso esse é um mundo inferior hierarquicamente ao inteligível. Cronos, ainda, mutila o pai. Significa que o Intelecto se autoconstitui no ato em que contempla o Um, diferenciando-se, tornando-se Um-múltiplo. Assim se estabelece um corte na unidade.

Com relação à ordem dos episódios na Teogonia, Plotino como que inverte a narrativa de Hesíodo. No

30. A propósito, Couloubaritsis $(1986,23)$ considera que a assimilação de Cronos ao Intelecto, por parte de Plotino, é uma "recuperação extraordinária” de um mito que pouco seduziu os homens. 
poema, primeiro Cronos emascula Urano, depois ele engole os filhos e, finalmente, Zeus toma o governo do mundo. Essa ordem está em conformidade com a ordem lógica dos acontecimentos metafísicos representados pelo mito: grosso modo, o Intelecto se separa do Um ao constituir-se, retendo em si as formas inteligíveis, então produz a Alma, que governa o mundo sensível. Porém o narrador fictício de V, 8 [31] 12, inicia a narrativa pelo episódio segundo o qual o deus retém em si os filhos, alegre com sua beleza, seguindo-se o acorrentamento de Cronos e a mutilação de Urano. Plotino efetivamente está discorrendo sobre o mundo inteligível e, nesse contexto, o mito começa por elucidar a constituição interna do Intelecto, passando em seguida a expor sua relação de intermediário entre a Alma e o Um.

Com respeito ao estatuto do mito, Hadot (1981a, 205-214, 210), em um estudo sobre as imagens míticas desse tratado, considera que os capítulos 12 e 13 não propõem uma interpretação alegórica, pois eles não explicam um mito, mas, ao contrário, ocultam dogmas platônicos sob o véu do mito. Mas se o mito revelasse dogmas filosóficos, ele não seria alegoria, na medida em que teria um sentido oculto? Talvez pensando nisso, em outro estudo publicado no mesmo ano, Hadot (1981b, 128 e129) tenha feito referência a esse tema mítico como alegoria. Pépin $(1955,21)$, por sua vez, considera que o mito da tríade divina representa o tema alegórico que as Enéadas mais desenvolvem. No tratado V, 1 [10], conforme foi visto, Plotino parece situar-se na linha dos alegoristas, ao fazer 
as teses metafísicas corresponderem ao que exprimem de modo velado os mistérios e os mitos. Mas o mesmo vale para V, 8 [31]? De certo modo, os capítulos $12 \mathrm{e}$ 13 não deixam de ter um tom alegórico, na medida em que versam sobre acontecimentos metafísicos por meio de episódios conhecidos envolvendo deuses da mitologia. Mas, de fato nesses dois capítulos Plotino não explica o mito. Portanto, não se pode caracterizá-los como capítulos de exegese alegórica, embora possam ser considerados como capítulos de expressão alegórica $^{31}$, que exigem uma leitura ativa, na qual seja feita a exegese alegórica do mito narrado. Convém ainda observar que esses capítulos são pontuados pela necessidade de buscar uma linguagem adequada para explicar o tema em questão. Ao findar o capítulo 13, Plotino indaga: "São, então, suficientes as coisas que foram ditas para conduzir a uma clara compreensão da região inteligível, ou é necessário percorrer de novo um outro caminho, no modo seguinte?” (V, 8 [31] 13, $22-24$ - trad. Soares) ${ }^{32}$ Por certo, a inclusão do narrador fictício e as frases que, ao final de cada capítulo, acenam para a necessidade de querer explicar, têm um colorido retórico. Mas, para além disso, a narrativa genealógica, com suas expressóes temporais de passa-

31. Lamberton $(1986,20)$ cuida em estabelecer a diferença entre expressão alegórica e interpretação alegórica, sendo esta última a elucidação da intenção ou do significado do texto.

32. Este outro caminho é o método de objeçôes e respostas, que no tratado V, 5 [32] é utilizado para expor que os inteligíveis são idênticos ao Intelecto e que o Um está além do belo (LAURENT, in: PLOTIN, n. 206, 127). 
do, presente e futuro, e com as relações de hierarquia e diferença entre filhos e pais, não deixa de ser um modo de tentar paliar as dificuldades em falar acerca do inteligível. Com efeito, o inteligível é eterno, portanto só pode ser dito adequadamente que é. Ou seja, a linguagem humana temporal não é apropriada para dizer a eternidade e a simultaneidade do inteligível sob todos os seus aspectos. Não obstante, para acentuar determinados aspectos, é cabível discorrer acerca do inteligível, através de uma linguagem figurada, na qual ele seja representado miticamente. Assim, por exemplo, as diferenças e as semelhanças entre pais e filhos concernem à relação entre imagem e modelo, que perpassa os três níveis de realidade, o Um, o Intelecto e a Alma. O narrador inspirado que anuncia o mito e as pontuações acerca da necessidade de explicar não deixam, portanto, de balizar, para o leitor, que se trata de uma narrativa a qual visa explicar a seu modo a região inteligível, não devendo ser interpretada de modo literal, como se se tratasse de deuses efetivamente. Mais do que isso, se a linguagem mítica compreende uma narrativa genealógica, as relaçôes hierárquicas são exibidas. O Intelecto é pai da Alma, mas é filho do Um; ele é um intermediário entre o pai e o filho, que reina sobre si mesmo. Significa que o Um é superior ao Intelecto, o qual, por sua vez, é superior à Alma nessa hierarquia de três termos. A superioridade é garantida pela relação de causalidade, figurada pela metáfora da paternidade, entre um e outro. Nesse caso, diferentemente da alegoria, que reabsorve dois sentidos, um aparente e outro oculto, na mesma figura, o mito da 
tríade divina em Plotino pode ser considerado um lógos que divide no tempo, por meio das genealogias, o que é ingerado, ou seja, eterno. Em outros termos, esse mito, tal como apresentado mais especificamente em V, 8 [31], confirma a própria teoria do mito plotiniana, a qual é efetivamente explicitada somente em um tratado tardio, III, 5 [50]. 
6.

FIGURAS MÍTICAS

Oonforme já foi visto, Plotino estabelece a função
tratado III, 5 [50], Sobre o amor, na qual está em ques-
tão a relação entre o tempo e mito. Mas também já é
sabido que, em boa parte dos casos nos quais se en-
contram alusões a figuras míticas nas Enéadas, Plotino
não as apresenta na estrutura genealógica que define
os discursos míticos.
Assim, este capítulo tem por escopo investigar o
que define as figuras míticas. Metodologicamente,
buscou-se por primeiro estabelecer o campo semân-
tico do mito, percorrendo as ocorrências do termo
mito, por um lado, e buscando o vocabulário relati-
vo ao mito nas próprias narrativas e passagens onde
aparecem figuras míticas, por outro. Disso resultou
um conjunto de termos que permite definir o caráter
ao mesmo tempo alusivo, enigmático e simbólico do
mito. O campo semântico do mito permite entrever 
o seu caráter figurativo, pois o mito mostra, manifesta, exibe algo. Disso decorre um conceito importante para este estudo: o mito é uma imagem que estabelece uma relação de semelhança assimétrica com seu objeto, na medida em que ele não o duplica, mas sim oferece uma figura dele.

Portanto, não parece estranho que, dentro deste conjunto de termos, um grupo chame especialmente a atenção: aquele formado por derivados da família de aînos que, em sua maioria, referem-se ou a mitos, ou aos discursos dos Antigos. Isso permite indagar se os dois tipos de discurso, o mítico e dos filósofos Antigos, mormente Platão, são similares. Considerando que Plotino é um exegeta de antigos discursos, a pergunta deve versar mais especificamente sobre a exegese de cada qual desses tipos de discurso, pois, sendo enigmáticos, evidencia-se a necessidade de uma hermenêutica.

Entretanto, as figuras míticas possuem uma força imagética própria, capaz de indicar uma via anagógica, o que é sugerido pela noção de mística, termo empregado por Plotino para designar um certo tipo de interpretação de mitos. Portanto, ainda que no âmbito da definição das figuras míticas tenha sido necessário retornar à questão da hermenêutica dos discursos míticos, cabe notar que, se há algo que as singulariza, é sua situação intermediária entre as imagens puramente figurativas e aquelas puramente discursivas, isto é, seu caráter anfíbólico.

O mito, para Plotino, é uma imagem da verdade. Portanto, para atingir essa verdade, é preciso ir além 
da narrativa, tal como o sábio que adentra o ádito do templo, passando pelas esculturas. O mito, com efeito, é uma imagem que tem um valor simbólico, semelhante ao das esculturas. Mas à diferença das esculturas e representaçōes pictóricas, que apresentam as partes todas juntas e simultaneamente, o mito é uma imagem que se desenvolve sucessivamente, apresentando as partes na ordem da narrativa.

\section{O VOCABULÁRIO DO MITO}

O campo semântico do mito pode ser delimitado a partir, seja das ocorrências do termo mito, seja dos próprios mitos. Claro que, nas apenas sete ocorrências do termo mito, Plotino está referindo-se a alguma figura mítica. Verificar-se-ão agora os termos que circunscrevem tal vocabulário, começando pelo conjunto das ocorrências de mŷthos, exceção feita à ocorrência que se encontra no tratado III, 5 [50], por ser aquela em que Plotino explicita a função genealógica dos mitos. Após o quê, será apresentada a lista de termos que se referem ao mito em passagens nas quais encontra-se alusão a alguma figura mítica, sem que, contudo, encontre-se o próprio termo mŷthos Observe-se que a segunda lista não é exaustiva. Optou-se por não repetir termos que já aparecem na primeira lista. Com o escopo de mostrar apenas o vocabulário, as passagens completas não serão apresentadas. Tão-somente serão elencadas, mostrando os termos na forma em que figuram no texto das Enéadas e a figura mítica em questão. 
Passagens em que ocorre o termo mythos

\begin{tabular}{|l|l|l|}
\hline a) I, 6 [1] 8,11 & Ainittetai & Figura anônima \\
\hline b) III, 6 [26] 14, 10 & $\begin{array}{l}\text { Poiê̂ } \\
\text { Endeiknýmenos }\end{array}$ & Poros, Penía \\
\hline c) IV, 3 [27] 14, 5-20 & $\begin{array}{l}\text { Ainittesthai } \\
\text { Sémaínoi } \\
\text { Emphaínein } \\
\text { Hoîon eikós } \\
\text { Prosáidō }\end{array}$ & $\begin{array}{l}\text { Prometeu, } \\
\text { Epimeteu, Pandora, } \\
\text { Héracles }\end{array}$ \\
\hline d) V, 1 [10] 7,32 & $\begin{array}{l}\text { Mystérion } \\
\text { Ainittontai }\end{array}$ & $\begin{array}{l}\text { Urano, Cronos, } \\
\text { Zeus }\end{array}$ \\
\hline e) V, 8 [32] 4, 26 & Ainittoménou & Linceu \\
\hline f) VI, 9 [9] 9,26 & Kaì en graphaîs en mýthois & Eros, Psiquê \\
\hline
\end{tabular}

Outras passagens

\begin{tabular}{|l|l|l|}
\hline g) V, 5 [32] 6, 27 & Symbolikôs & Apolo \\
\hline $\begin{array}{l}\text { h) III, 5 [50] 5, 5 } \\
\text { IV, 3 [27] 13, 21 }\end{array}$ & $\begin{array}{l}\text { Hyponooîto } \\
\text { Hyponoeîn }\end{array}$ & $\begin{array}{l}\text { Eros } \\
\text { Lete }\end{array}$ \\
\hline i) III, 6 [26] 19, 26 & $\begin{array}{l}\text { Mystikôs } \\
\text { Teletầs }\end{array}$ & Hermes \\
\hline j) III, 5 [50] 8, 22 & $\begin{array}{l}\text { Tôi lógōi ieréón kaì } \\
\text { theológōn }\end{array}$ & Hera, Afrodite \\
\hline k) II, 3 [52] 15,10 & Legoménōn & $\begin{array}{l}\text { Moiras, Láquesis, } \\
\text { Átropo }\end{array}$ \\
\hline
\end{tabular}

\section{IMAGEM E IMAGINAÇÃO}

Em uma ocorrência do termo mŷthos, Plotino estabelece uma analogia com pinturas: as figuras de Eros e Psiquê normalmente são representadas juntas nas pinturas e nos mitos (kaì en graphaîs kaì en mýthois - VI, 9 [9] 9, 26). Ambos, mitos e pinturas, são representações sensíveis da verdade inteligível. Isso se fundamenta efetivamente na relação entre o modelo inteligível, e a imagem sensível, que é de 
semelhança. Esta pode ser simétrica, ou assimétrica, como propôs Schroeder em "Plotinus and Language" (1996, 337-338). A relação é simétrica entre duas coisas que se assemelham mutuamente, digamos duas cadeiras, uma tendo a outra por modelo, e assimétrica, quando a imagem não duplica o modelo. Por exemplo, uma pintura não pode duplicar o modelo, mas sim oferecer uma versão dele. A relação assimétrica Schroeder propõe designá-la por representação. Portanto, se o mito é um tipo de imagem que indica o modelo, não o duplicando, pode-se dizer que ele representa aquilo a que alude.

Isso também parece ser denotado pelo termo

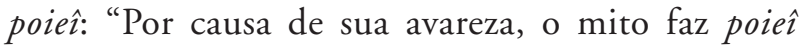
dela uma mendiga, mostrando (endeiknýmenos) assim sua verdadeira natureza, que é a privação do Bem” (III, 6 [26] 14, 10-12). Ora, é sabido que Platão havia empregado o vocábulo poiéo referindose tanto à produção do cosmos pelo demiurgo, no Timeu, como ao poeta produzindo um mito (BRISSON, 2003, 259-270) ${ }^{1}$. No uso comum, o verbo poiéó significa ação de fabricar em geral. A tradição helênica, por sua vez, legou a Plotino a divisão da ação em duas espécies, distinguindo poíésis e práxis. Um tipo de ação é acompanhada de páthos, desestabilizando o sujeito em que ela se produz; esta é denominada prâxis. O outro tipo de ação é a manifestação de uma pleni-

1. PLATÃO, Fédon, 61 b; República, 377 c; 379 a. Brisson detém-se na homologia entre os vocábulos relativos à produção do cosmos e da fabricação de mitos em Platão e seus intérpretes neoplatônicos. 
tude que não sofre nenhuma mudança, de tal modo que esta é uma ação perfeita, a qual se confunde com a contemplação, sendo designada pelo verbo poieîn (ARNOU, 1921, 41). Donde é possível observar que, por um lado, Plotino está fazendo uso de um termo que pode designar a produção humana de modo geral; mas poieîn, por igual, pertence ao formulário platônico relativo ao mito. A diferença em Plotino é que o tipo de ação designada por esse termo recebe um novo matiz, ao confundir-se com a contemplação. Portanto, o mito, ao produzir uma imagem, ao mesmo tempo sugere a contemplação do modelo. Assim, no exemplo supracitado, a "mendiga” Penía é a imagem mítica de "privação do Bem"2.

No mesmo exemplo encontra-se endeíknymai com o sentido de mostrar, que lhe é corrente. Com efeito, o verbo deíknymi precedido do sufixo - en significa mostrar, dar um exemplo, sendo empregado também como um termo retórico. Mas não se pode deixar de observar que a forma deiknýmena designa tudo o que era mostrado nos mistérios de Elêusis: emblemas, pinturas, esculturas, objetos sagrados (FOUCART, 1999, 357). É sabido que, a partir de Plutarco, há uma associação entre mitos e

2. Pode-se contemplar aquilo que é definido pela privação? Não, pois a matéria não é, nada possui, nem mesmo materialidade, portanto não é passível de ser contemplada, nem mesmo conhecida, a não ser talvez através de um raciocínio bastardo, como a chôra do Timeu. Entretanto, exatamente porque escapa ao âmbito do sensível, e ao do inteligível, a matéria tampouco pode ser um objeto adequado às determinações do discurso, donde para ela também valem certos recursos da linguagem, como é o caso do mito. 
mistérios, e que isso encontra um fundamento lexical notadamente nos diálogos Fedro e Banquete. Na sequência dessa seção, será possível entrar em detalhes no tocante a tal assunto, pois, como mostra o elenco de termos, há um bom número que remete aos mistérios e iniciaçôes, dentre os quais endeíknymai, embora não exclusivamente, já que pode ser compreendido apenas no sentido geral de mostrar.

Há outro verbo da lista que significa mostrar, mas também manifestar, exibir: emphaino ${ }^{-3}$. Nesse caso, logo após narrar o mito de Prometeu plasmando Pandora, Plotino diz: "Pois bem, interprete-se isso segundo sua opinião, mas <este mito> mostra (emphainein) o que é o presente dado ao mundo e foi recitado (prosáidei) de acordo com o dito" (IV, 3 [27] 14, 17-19)4. Ora, é fato que a postura alegórica exige uma hermenêutica do mito. Mas, nessa frase, Plotino sugere que, independentemente da interpretação, o mito mostra determinada coisa, e que isso está de acordo com aquilo que vinha sendo exposto antes. Portanto, de certo modo, o mito confirma o discurso anterior. Mas, por outro lado, o que significa dizer que o mito mostra? Para responder a essa questão, é fundamental voltar à relação entre modelo e imagem, especialmente entre o mo-

3. A análise lexical das onze ocorrências de emphainō e seus cognatos, nas Enéadas, assim como das dezesseis de endeíknymai e suas flexōes, permite deduzir que são usados com o sentido de mostrar, tornar visível em diferentes situações.

4. O termo prosáidei será visto quando esta mesma passagem é novamente citada, no contexto da análise do mito de Prometeu. Isso se justifica, porque este termo escapa ao campo semântico da imagem. 
delo inteligível e sua representação sensível. Embora o inteligível não se manifeste somente nas produçōes humanas, e sim em qualquer vestígio de ordem e de beleza do mundo sensível ${ }^{5}$, Plotino considera que os sons sensíveis na música, por exemplo, são uma representação da harmonia inteligível. A geometria e a aritmética representam a simetria, a ordem e a proporção. A pintura remete à forma do belo, e quem é capaz de reconhecer essa forma tem uma lembrança da verdade (II, 9 [33] 16, 40-47). Sobre a linguagem pode-se começar lendo um passo bastante conhecido das Enéadas, no qual Plotino refere-se ao modo como os sábios egípcios ilustravam o conhecimento que possuíam:

\begin{abstract}
Parece-me que os sábios do Egito compreenderam isso, seja por uma ciência exata, seja de modo inato: quando queriam expor algo de modo sábio, não usavam os caracteres que são letras, que desenvolvem as palavras e as proposiçôes, e nem mesmo sons e pronúncias de princípios, mas desenhando imagens (agálmata) e entalhando uma só imagem (ágalma) para cada coisa nos templos, mos-
\end{abstract}

5. "Agora, se quem vê a beleza bem representada em um rosto se transporta para lá, haverá alguém de pensamento tão preguiçoso e que não será movido a nada outro que, olhando para a totalidade das belezas presentes no sensível, e a totalidade da simetria, e este grandioso ordenamento, e a forma transluzente (emphainómenon) nos astros embora estejam distantes, não deduza disto, - e a veneração o arrebata -, a partir dessas consequências, como são aqueles inteligíveis? Então, esse nem compreendeu estas coisas nem viu aquelas" (II, 9 [33] 16, 48-56 - trad. Baracat Jr.). 
travam (emphainein) a não-discursividade de lá, de modo que cada imagem (ágalma) seja uma certa ciência, um saber, um substrato e um todo reunido (athróon), e não pensamento discursivo nem deliberação (V, 8 [31] 6, 1-9).

Inicialmente, observe-se, tais imagens (agálmata) foram executadas por sábios do Egito (hoi Aigyptíon sophoî), o que remete a uma tradição religiosa venerável. Ora, o hieróglifo, forma mais antiga da escritura egípcia, à época de Plotino, era reservado a contextos religiosos e monumentais ${ }^{6}$. Enfim, isso significa que o simbolismo das "letras sagradas gravadas" (tà ieroglyphiká) não era de conhecimento geral, mas, antes, possivelmente, restrito aos sacerdotes e iniciados e talvez a alguns devotos. Por fim, aqueles que eram capazes de decifrar a escritura figurada dos templos sabiam que o sentido não se encontrava, à primeira vista, na superfície das imagens ${ }^{7}$. Assim, no exemplo da escrita

6. Isso parece ter-se dado devido ao desenvolvimento da sua versão cursiva, a hierática, seguida, posteriormente, na chamada época grega, pelo demótico, atestado já por volta de 700 a.C. e, depois, na época romana, pelo copta, atestado a partir do século III d.C.

7. No Egito romano e ainda possivelmente no início da cristianização, enquanto ainda sobreviviam as antigas tradiçôes, "a escrita sagrada, todavia, era praticada ainda pelos sacerdotes nos recintos dos templos onde, separados do mundo, cultivavam os monumentos da sua cultura tradicional em fase de desaparecimento (...). Nestas circunstâncias acabaram complicando progressivamente a própria escrita, que a essa altura não servia mais para fins práticos e se tornara mero instrumento iniciático. A essa altura jogava-se com as possibilidades permitidas por uma escrita que se desenvolvia no duplo registro fonético e ideográfico. (...) Em torno do 
dos templos egípcios, não se trata de comparar um sistema de escrita com outro, mas, sim, modos de expressão, como observa De Keyser $(1955,53-65)^{8}$ : a imagem desenhada nos templos abre acesso imediato a um pensamento rico em significados, enquanto o modo discursivo exige que se siga um desenvolvimento analítico. Dessarte, vale observar, esses modos de expressão não se excluem, antes, ao contrário, parece que, no caso da linguagem, ao menos, se complementam. Com efeito, para Plotino, na escrita hieroglífica dos egípcios, cada signo tem o valor de um conceito, que se pode associar a outro conceito, expresso por outro signo, sem aparentemente passar pelos elementos do discurso. Isso sugere que o mundo inteligível tem uma natureza figurativa, mas não discursiva, e que os ideogramas egípcios reproduzem diretamente as formas inteligíveis (PÉPIN, 1982, 95). Portanto, eles permitem um conhecimento imediato e total do inteligível (GRABAR, 1945, 24), de tal sorte que estes agálmata egípcios parecem ser um tipo de imagem comparável às formas inteligíveis; imagens semelhantes àquelas que o sacerdote contempla no ádito dos

termo representado (que era preciso ler foneticamente), criava-se desse modo um halo de conotações, de segundos sentidos, como um fundo obstinado de sugestóes que concorriam para ampliar a área semântica do próprio termo. Nesta atmosfera aumentava cada vez mais a convicção de que os antigos textos conteriam verdades ocultas, segredos perdidos" (ECO, 2001, 186-187).

8. Note-se que De Keyser considera que as imagens dos templos, na referida passagem, não podem limitar-se aos hieróglifos, mas dizem respeito a todas as imagens simbólicas que aparecem nas paredes dos santuários do culto faraônico, tais como os anáglifos, por exemplo. 
templos (DE KEYSER, 1955, 59) ${ }^{9}$. Não obstante, para evitar confusão entre imagens ontologicamente diversas, é mister relevar que a chamada natureza figurativa do inteligível refere-se às formas, as quais estão mutuamente absorvidas em um sistema diáfano, para usar uma expressão de Jankélévitch $(1998,78)$. Ou seja, é necessário notar que as imagens inteligíveis não possuem a mesma natureza das imagens grafadas, sejam elas pintadas ou escritas. Isso porque no inteligível encontram-se as formas, que são os modelos para as imagens psíquicas e, por consequência, para as sensíveis. São imagens hierarquicamente superiores e invisíveis, pois a visibilidade é um atributo dos corpos. Portanto, é apenas por analogia que as imagens hieroglíficas são comparáveis às imagens inteligíveis. Voltando ao exemplo dos hieróglifos egípcios, Plotino considera que, após essa síntese da imagem, há um desenvolvimento, uma explicação da imagem, como indica a sequência da passagem:

Depois daquele saber todo reunido vem uma imagem (eídōlon) já em outra coisa desenrolada (en állöi exeiligménon) e que diz a si mesma desenvolvendo-se (légon hautò en diexódōi) e as causas (...) (V, 8 [31] 6, 9-11).

9. O estudioso observa que o termo ágalma não tem um sentido preciso para Plotino: pode indicar escultura de um deus, de um homem, da justiça, de um ser celeste, mas também representação desenhada e, ainda, imagens inteligíveis. 
Note-se que o termo eídōlon figura nas Enéadas com o sentido geral de imagem, mas também significando imagem refletida no espelho ou na superfície da água (SLEEMAN \& POLLET, 1990, col. 299). Este último sentido não é subentendido no termo ágalma. Portanto, aqui Plotino parece não marcar somente uma diferença lexical, mas sim uma distinção conceitual. Em outros termos, ágalma parece designar um tipo de imagem que simboliza o inteligível como um todo unificado, enquanto eídōlon refere-se a um tipo de imagem que representa o inteligível em outra coisa (en álloì), de forma desenrolada. Ou, por outra, as imagens (agálmata) representam os inteligíveis tais como eles são, todos juntos no mesmo plano, por assim dizer, enquanto as imagens designadas pelo termo eidōlon representam os inteligíveis de forma desenvolvida, isto é, discursiva. O verbo exelitt cujo sentido primeiro é desenrolar, parece indicar que as imagens dos inteligíveis produzem ou mesmo provocam explicaçôes dos seres inteligíveis. Ademais, este verbo parece remeter a certa continuidade entre as imagens e o próprio inteligível, na medida em que Plotino o emprega tanto para designar diferentes níveis no âmago do inteligível ${ }^{10}$, como a própria vinda à existência do Intelecto ${ }^{11}$. Com efeito, as imagens que constituem

10. Os seres inteligíveis são potências do Intelecto que, se desenvolvendo (exelittómenai), descem em relação ao que está no alto (VI, 7 [38] 9, 38-39).

11. O Intelecto e os seres nascem do Um por assim dizer procedendo, se desenvolvendo (exelikhthén) e permanecendo suspensos nele (VI, 8 [39] 18, 19-20). 
objetos de conhecimento da alma são desenvolvimentos dos seres inteligíveis, isto é, são os próprios seres inteligíveis em estado menos unificado (COLLETTE, 2002, 59). Nas Enéadas a produção não é independente do produtor, logo, sempre deve haver algum tipo de continuidade entre um e outro. Portanto, esta breve referência ao verbo exelittōo apenas ilustra tal continuidade, seja nos níveis inteligíveis, seja entre o modelo inteligível e a imagem sensível.

Sob outro ponto de vista, pode-se notar também uma continuidade entre o inteligível e as imagens produzidas a partir dele na faculdade da imaginação. Em linhas gerais, a imaginação recebe imagens advindas dos dois planos, sensível e inteligível (IV, 3 [27] 30, 15-16), sendo, portanto, uma faculdade intermediária entre ambos. É preciso considerar, preliminarmente, que, para Plotino, há diferentes faculdades da alma, onde se percebe uma correspondência entre categorias cognitivas e ontológicas. Resumidamente, primeiro encontra-se a sensação, faculdade através da qual se apreendem as qualidades dos corpos sensíveis, as quais equivalem aos lógoi escorridos para a matéria. Essa distinção é importante para Plotino, porquanto a alma só pode receber coisas semelhantes a ela mesma, ainda que tais coisas provenham de corpos sensíveis ${ }^{12}$. A imaginação surge então como uma faculdade posterior à sensação, pois ela forma imagens a partir das

12. A consequência disso seria a incognoscibilidade da matéria, haja vista que a alma somente recebe os elementos inteligíveis dos corpos sensíveis. 
qualidades recebidas pela sensação, e tais imagens serão julgadas pelo pensamento discursivo. Mas, por outro lado, ela também recebe imagens advindas do inteligível.

Plotino considera que a faculdade da imaginação recebe o lógos que acompanha o pensamento (toû lógou toû tôi noếmati parakolouthoûntos). O pensamento, enquanto permanece interior, não possui partes, e, portanto, nos escapa. Mas quando o lógos o desenvolve, o exterioriza, fazendo com que saia do estado de pensamento puro, para entrar na faculdade da imaginação, revela-o como em um espelho. Então se produzem a apreensão (antílépsis) do pensamento e a memória, que é persistência das imagens na imaginação $\left(\mathrm{V}, 3\right.$ [27] 30, 5-11) ${ }^{13}$. Nesse ponto, parece que os pensamentos abstratos (noémata), quando postos nos esquemas representativos da imaginação, adquirem uma consistência de dados concretos. Por um lado, essa irrupção do imaginário no âmbito do inteligível corresponde a uma certa degradação da theōría mas, por outro lado, uma consequência que se pode tirar dessa ligação complexa das faculdades da alma é sua unidade (MOUTSOPOULOS, 2000, 46-47). Todavia, cabe notar que se, nessa passagem, a imagem especular, produzida na imaginação, acompanha o pensamento, não significa que Plotino, como

13. Para Bergson $(2005,73-74)$, a antílēpsis recobre a mesma extensão que a vida da alma: um intermediário entre o sensível e o inteligível, um devir. Ele também considera que ela unifica as impressôes vindas de baixo, e divide as de cima. Parece que está correto, uma vez que a percepção opera sobre os dados da imaginação, que recebe impressões de ambos os lados. 
Aristóteles, considere que a alma sempre pense com imagem (phántasma) ${ }^{14}$. Com efeito, para Plotino, há uma circunstância em que a alma se libera das imagens produzidas pela imaginação: quando ela se subtrai do pensamento discursivo e se volta para o inteligível, em atividade contemplativa (I, 4 [46] 10, 3-20).

Quanto à imagem, pode-se dizer que ela define os contornos do pensamento; "mais que um reflexo, ela se impóe à consciência para a qual oferece um meio de expressão" (MOUTSOPOULOS, 2000, 75) ${ }^{15}$. Com efeito, Moutsopoulos (2000, p. 77) considera que a imagem fruto da faculdade imaginativa, não é somente um reflexo da realidade, seja da sensível ou da inteligível. A imagem é uma realidade, um fato psíquico, que incita o pensamento discursivo a se explicitar formalmente através da palavra. É também um movimento da alma, tanto em direção àquilo que ela imagina, como a partir daquilo. Seu grau de realidade não depende somente da semelhança com o que ela imagina, mas também com a possibilidade que ela oferece de apreender o inteligível, expondo-o através dela. Por conseguinte, a imagem é tanto o princípio como o agente da participação da alma nas realidades

14. Sobre a afirmação "a alma nunca pensa sem imagem (phántasma)", ver Aristóteles, De Anima, I, 1, 403 a 8-9; III, 7, 431 a 16-17; III, 8, 432 a 8-9. De memoria, I, 449 b $28-450$ a 14 . A respeito da diferença entre Plotino e Aristóteles, pode-se consultar COLLETTE (2003, 115-135); MOUTSOPOULOS (2000, 47).

15. Parece tratar-se da imagem que se forma na alma, graças à faculdade da representação, pois a passagem que está em tese é ainda o começo de IV, 3 [27] 30. 
inteligíveis, ainda que não seja necessariamente tal realidade. Daí pode aduzir-se que o mito, este tipo de imagem-discursiva, concerne a duas faculdades da alma, à imaginação e ao pensamento discursivo. Na medida em que se mostra como figura, o mito penetra a imaginação, oferecendo representações psíquicas, que, por sua semelhança assimétrica com as formas inteligíveis, podem ser projetadas sobre estas mesmas formas, no plano do pensamento discursivo. Donde se encontram os dois aspectos do mito e as duas faculdades que ele tange.

\section{O CARÁTER ENIGMÁTICO DO MITO}

Retornando ao léxico do mito, pode-se dizer que o mito é uma imagem que sinaliza, indica (sémaínoi). No esmo campo pode-se ainda incluir o termo symbolikôs. Logo, o mito ele próprio não é a verdade, mas, sim, um sinal em direção à verdade. Portanto, o mito tem um caráter de verossimilhança. Em uma das passagens listadas, lê-se: "Como é verossímil (hoîon eikós) o que o mito diz de modo velado (ainittesthai)" (IV, 3 [27] 14, 5). Embora tenha sido omitida, quase todos os mitos aqui mencionados são acompanhados da partícula hoîon, que, em um primeiro nível de significação, designa a relação de analogia entre a figura mítica e aquilo que ela representa. Quanto a eikós pode-se indagar se remete à mesma noção encontrada no Timeu, o qual é qualificado de eikồs mŷthos três vezes, e de eikồs lógos dezesseis vezes ${ }^{16}$. Brisson (1994, 161-163) demonstrou

16. Eikòs mythos: Timeu, 59c, 68d, 69b. Eikòs lógos: Timeu, 30b, 34c, 44d, 48c, 49b, 53d, 55d, 56a, 56d, 57d, 59c, 68d, 72d, 90e. 
que eikòs, traduzido por verossímil (vraisemblable) deve, em senso estrito, ser compreendido como aquilo que concerne às cópias do modelo inteligível, isto é, o mundo sensível. Ora, é consabido que o Timeu versa sobre o universo sensível, como e por que ele foi engendrado. Neste caso, haveria um paralelismo entre o discurso ou o mito verossímil e os objetos a que ele se aplica, os quais têm o caráter de eikónes ${ }^{17}$. Assim seria uma relação entre dois tipos de imagens sensíveis: o universo sensível, de um lado, e o discurso de outro. Parece que o mesmo não ocorre em Plotino, pois os mitos versam sobre todos os níveis, do Um à matéria, mas especialmente sobre a Alma ${ }^{18}$. Com efeito, em Plotino não parece haver um paralelismo entre dois tipos de imagem, os mitos, qualificados de hoîon eikós, e seus objetos. Portanto, em Plotino trata-se antes de uma relação entre um tipo de imagem alusiva, e por isso verossímil, e aquilo a que tal imagem alude. Por isso talvez Plotino necessite de um conjunto de termos para indicar esse aspecto alusivo do mito. Há termos que remetem ao vocabulário da alegoria, designando palavras com duplo sentido e, portanto, um discurso alusivo, tais como hyponoéo.

17. Berti $(1997,127)$ acentua o paralelismo entre o tipo de discurso do Timeu e seu objeto. Observe-se que eikón é uma imagem que corresponde ao original, permitindo entrever a realidade da qual ele é imagem, à diferença do phántasma (SANTA CRUZ, 1997a, 136).

18. A análise das genealogias de Eros e Afrodite bem exemplificou isso. Por outro lado, é mister notar que os mitos não possuem um referencial fixo. Trata-se do caráter de polivalência dos mitos, a qual é mais particularmente tematizada no último capítulo, que versa sobre Zeus. 
O termo mais antigo a designar a alegoria é hypónoia, que tem o sentido primeiro de "suspeita", "conjetura”. Este substantivo corresponde ao verbo hyponoéo que significa "suspeitar"19, mas também "ver", "pensar sob”. Segundo Pépin $(1976,85)$, em um sentido geral designa a operação, muitas vezes elementar, que faz um dado percebido se tornar uma hipótese. Em outros termos, a passagem da sensação à conjetura constitui a hypónoia. Outra acepção de hypónoia está ligada à interpretação alegórica de poemas, mitos e representaçôes plásticas ${ }^{20}$ : trata-se de decifrar nelas o sentido oculto ou subentendido. Esse sentido particular não se afasta do sentido mais geral, uma vez que concerne à relação entre um dado sensível e uma representação intelectual. Quanto à tradução desse termo para o vernáculo, é lícito guardar a polissemia, optando, ora por "sentido profundo", ora por "subentendido", ou ainda, por "alegoria", quando se refere de modo especial à interpretação de mitos. O uso técnico do termo hypónoia parece remontar aproximadamente ao IV século a.C. (CHIRON, 2004, 52). É digno de nota que a filosofia não desconhece o emprego da hypónoia: Pitágoras e Heráclito fizeram uso da linguagem com duplo sentido. Platão, ao aventar a hipótese de que

19. Em Aristófanes, $A$ paz, 993, o termo aparece com o sentido de suspeita. Em Platão, há uma ocorrência com esse sentido nas Leis 679 c5.

20. E neste caso, um bom exemplo se encontra em Eurípides, As Fenícias, 1128 - 1133, ao descrever a imagem em relevo do escudo de Capaneu dizendo que é símbolo (hypónoian) da sorte reservada à cidade. 
Homero tenha forjado narrativas com duplo sentido, serve-se exatamente desse termo (PLATÃO, República, 378 d 3 e 3$)^{21}$. A partir do século I a.C., hypónoia vai cedendo lugar ao termo grego allégoría, que provém do vocabulário dos gramáticos ${ }^{22}$.

Etimologicamente a palavra allégoría é formada por állos, "outro", e agoreúo, "eu falo" ${ }^{23}$. Quer dizer, ao se falar de algo, fala-se, na verdade, de outra coisa. Compreendida como expressão,

na Antiguidade a allegoría é uma forma de metáfora particularmente valorizada (...): ela é um signo, textual ou visual, que permite expressar de diferentes maneiras (imagem, metáfora, parábola, etc.) um certo conteúdo de pensamento concreto ou abstrato (...). Este procedimento figurativo é utilizado, em particular, cada vez que se trata de traduzir um conteúdo

21. Nessa passagem encontram-se efetivamente as três únicas ocorrências do substantivo hypónoia no corpus platônico. Há apenas duas ocorrências do verbo hyponoéó no corpus platônico, em Górgias, 454 b - c; e Leis, 676 c (BRISSON, 1994, 153-154.

22. Uma das mais antigas ocorrências do termo encontra-se, por exemplo, em Filodemo de Gadara, c. 110 - 40 a.C. (BUFFIÈRE, 1956, n. 12**, 47).

23. O leitor interessado na história da alegoria pode consultar, por exemplo, TATE (1934, 105-114). Também os já mencionados BUFFIÈRE (1956); PÉPIN (1976); BRISSON (1996); PEREZ-JEAN, EICHEK-LOJKINE (2004). 
intelectual abstrato em um conteúdo sensível e visível (WUNENBURGER, 1997, 41) ${ }^{24}$.

Mas, como já foi dito rapidamente, a alegoria subsume dois sentidos: o de expressão alegórica, e o de exegese alegórica. Como exegese, o conceito de alegoria parece ter adquirido um sentido diferente para a filosofia, em relação à gramática e à retórica. Esse novo sentido deriva possivelmente de uma antiga prática dos poetas. É certo, porém, que ele decorre dos métodos exegéticos empregados durante séculos pelos filósofos com o fito de compreender o sentido subentendido de textos poéticos. Desse uso exegético a alegoria assume, para certos filósofos, outra função: superar limites próprios da linguagem, quando o referente escapa ao domínio do mundo físico. Em outros termos, a alegoria passa a caracterizar-se, embora não exclusivamente, como uma ferramenta da filosofia. Desse modo, aqueles platônicos que se ocuparam com a exegese dos antigos poetas, longe de fazer da alegoria um meio de adornar suas palavras, acreditam que a alegoria é o único modo de expressar o que querem dizer $^{25}$. Não é por acaso que termos como "símbolo",

24. A linguagem dá lugar a tipos específicos de imagens, como a metáfora, por exemplo, cujas equivalências estruturais e ou funcionais com a imagem visual podem ser fonte de numerosas dificuldades. Por outro lado, é incontestável que há uma ligação entre o verbal e o visual nessa categoria de imagens, à qual pertencem também o mito e a alegoria.

25. Com o objetivo de mostrar que a alegoria não tem uma função meramente ornamental nos textos filosóficos, Boys-Stones (2003, 3) menciona, além dos platônicos, também a teogonia órfica do 
"enigma”, "subentendido", têm seu sentido subsumido ao de alegoria. Esses termos apareceram nos textos antes da própria palavra grega alegoria (allégoría), a qual, como visto, é de uso tardio em relação à prática que costumeiramente é chamada alegórica. Plutarco de Queronéia é testemunho dessa mudança no vocabulário: "Estes mitos, alguns comentadores, com o que outrora chamavam de subentendido (tâ̂s pálai mèn hyponoíais), e que chamamos agora alegorias (allégoríais dè nŷn legoménais), torturam e falseiam a interpretação" (PLUTARCO, Como o jovem deve escutar os poetas, 4, Moralia, 19) ${ }^{26}$. Nessa passagem, Plutarco faz referência à interpretação astronômica do adultério de Afrodite e Ares, e também a uma interpretação física do cinto mágico de $\mathrm{Hera}^{27}$. Com efeito, Plutarco parece empre-

papiro de Deverny, segundo a qual Orfeu não teria escrito alegoricamente para formosear seu discurso. Do mesmo modo, para Filo de Alexandria, Moisés não teria escrito a Tora sob forma alegórica por motivos retóricos, até porque, segundo Filo, a presença de alegoria parece indicar uma violação do bom estilo retórico.

26. Efetivamente, o substantivo grego allégoría e seus cognatos ocorrem poucas vezes em Plutarco. À parte a passagem supracitada, verificam-se em: Sobre Isis e Osiris, 28, 32, Moralia 362 b 1, 363 d 5; Diálogos Píticos, 30, Moralia 409 d 2; Sobre comer carne $I$, = Moralia 996 b 10 .

27. Eis a passagem completa: "Estes mitos, alguns, com o que eles chamavam outrora subentendido, e que chamamos agora alegorias, torturam e falseiam a interpretação. $\mathrm{O}$ adultério de Afrodite e Ares, denunciado por Hélio, significa que a conjunção dos planetas Marte e Vênus determina naqueles que nascem sob seu signo, o gosto pelo adultério, e que, se o sol, subindo no céu, os surpreende, estes adúlteros não permanecem ocultos. Quando Hera veste-se em honra a Zeus e recorre a um cinto mágico, querem que se trate na realidade de uma purificação do ar que se 
gar a palavra alegoria para descrever a prática estóica de exegese mítica, que pode ser resumida a um procedimento segundo o qual as figuras míticas simbolizam elementos físicos, morais ou psicológicos (BRISSON, $2004,32)^{28}$. Porém, a associação dos mitos aos mistérios induzirá a outra mudança vocabular, da qual as interpretações de Plutarco também são emblemáticas: o termo alegoria vê-se substituído por ainigma, sýmbolon e ainittesthai, além de seus cognatos, o que afinal indica a associação dos mitos aos mistérios ${ }^{29}$. Não obstante, esses termos adquirem um sentido especializado que não possuíam antes. Finalmente, com o escopo de ilustrar essa mudança de vocabulário, podem-se mencionar algumas das ocorrências de ainittetai e ainittesthai em Plutarco. Ao interpretar o mito egípcio de Ísis e Osíris, Plutarco associa esses termos à palavra mito, para designar o que o mito diz de modo subentendido, por exemplo: "Este mito nos dá a entender (ainittetai) que a razão deste deus (...)", referindo-se a Zeus (PLUTARCO, Sobre Isis e Osiris, 62, Moralia, 376 c 6). Os termos figuram, igualmente, designando a exegese do mito egípcio: Tífon designa de modo subentendido (ainittetai) os ventos do sul. O desmem-

aproxima do elemento ígneo. Como se o poeta não desse ele próprio uma explicação!" (PLUTARCO, Como o jovem deve escutar os poetas, 4, Moralia, 19). Sobre o adultério de Afrodite e Ares, ver HOMERO, Odisséia, VIII, 266-369. Sobre a vestimenta de Hera, ver HOMERO, Ilíada, XIV, 153-189.

28. Sobre a alegoria no estoicismo grego, ver GOULET (2005).

29. Sabe-se que Plutarco e sua esposa eram iniciados nos mistérios de Dioniso (PLUTARCO, Consolação à sua esposa, 10, Moralia, $611 \mathrm{~d}$ 6-10). 
bramento de Osíris em quatorze pedaços indica, por palavras encobertas (ainittontai), o número de dias durante os quais a lua decresce. Os egípcios querem nos fazer subentender (ainittetai) que, antes de o nosso mundo tornar-se visível (...) (PLUTARCO, Sobre Ísis e Osiris, 39, Moralia, 366 c 10; Sobre Ísis e Osíris, 42, Moralia, 368 a 7; Sobre Ísis e Osiris, 54, Moralia, 373 b 10). Um último exemplo, à guisa de conclusão, referindo-se a Tífon, mas agora como daimon: "Este mito deixa subentendido (ainittesthai) que todas as naturezas brutais e ferozes são patrimônio deste daimon (...)" (PLUTARCO, Sobre Ísis e Osiris, 73, Moralia, 380 c 3).

Denotando certa continuidade entre Plotino e Plutarco, um termo importante que caracteriza o mito nas Enéadas é o verbo ainittomai ${ }^{30}$ referindo-se ao que o mito diz obscuramente, por enigmas, ou ainda, veladamente, alusivamente. Com efeito, à época de Plotino, o verbo ainittomai significa "falar por enigmas" 31 , ou seja, dizer palavras significativas, mas difíceis de compreender. Portanto, significa fazer uso de palavras com duplo sentido, um aparente, mas superficial, e um oculto, mas profundo, que encerra a verdade. Nisso, não parece diferir do sentido lato do termo alegoria. De fato, ainittomai expressa uma postura alegórica, porquanto supóe que o exegeta seja capaz de desvendar o sentido verdadeiro oculto sob o literal. O aporte desse termo para o estudo da interpretação de mitos é

30. Observa-se que, dentre todas as ocorrências da palavra mito nas Enéadas, em quatro figura o verbo ainóttomai na forma ática.

31. Construção a partir do presente ainissomai. No sentido passivo: einikhthèn, éinigmai. 
a demarcação da mudança do paradigma das alegorias de cunho estóico, para aquelas que têm por pano de fundo a associação dos mitos aos mistérios, de tal modo que se pode estabelecer uma assimilação entre alegoria e iniciação. Essas alegorias mistéricas, como acaba de ser visto, têm em Plutarco uma referência fundamental, e farão fortuna entre os neoplatônicos.

A palavra iniciação (teletế), na Antiguidade, remete à passagem de um modo de vida a outro, para um indivíduo. Normalmente o termo está ligado às religióes de mistério, nas quais a palavra e a ação intervinham, permitindo a um indivíduo mudar sua relação com o divino e, por conseguinte, modificar seu estado de alma (BRISSON, 2004, 29). Para os neoplatônicos, a filosofia tem por escopo conduzir o indivíduo a unir sua alma ao primeiro princípio. Isso significa mudar o estado de alma e, por conseguinte, viver outro modo de vida, virtuoso. Essa concepção da filosofia resulta de certa leitura que os neoplatônicos em geral fizeram de passagens do Fedro e do Banquete, nas quais Platão faz uso do vocabulário dos mistérios e associa a filosofia às iniciações ${ }^{32}$.

Dito isso, vale observar, ainda, que, do ponto de vista histórico, a especialização do sentido desse termo reflete certos fatos, tais como a prática do comentário, a influência de preocupações religiosas sobre a filosofia e o estabelecimento de uma nova interpretação do platonismo,

32. Sobre o tema, consultar RIEDWEG (1987, 1-69). Sobre a filosofia como modo de vida na Antiguidade, ver os estudos de Pierre Hadot. 
associado ao pitagorismo (BRISSON, 2004, 29). Como se sabe, o comentário vai se tornando o modo de fazer filosofia nas Escolas, significando uma mudança radical no ensino da filosofia, a tal ponto que no século I d.C., de modo geral, a filosofia adquire decisivamente a forma de um comentário de texto ${ }^{33}$. O ensino passa a consistir na explicação dos textos das "autoridades": Platão, Aristóteles, Crisipo, Epicuro. E a verdade é representada pela fidelidade à tradição fixada nos textos das "autoridades". Assim, partindo do pressuposto de que os fundadores das Escolas haviam atingido a verdade, os exegetas viam a necessidade de interpretar os textos, pois a verdade não se encontrava expressa de modo claro e imediato. Donde a ideia de "duplo sentido" também no âmbito da hermenêutica de textos filosóficos. Ora, os médio-platônicos, deparando-se com essa dificuldade, foram sensíveis à

33. Por certo, o comentário filosófico é bem mais antigo; há registro de um comentário sobre o Timeu composto por Cantor em 300 a.C. (PROCLO, Comentário sobre o Timeu, t. I, p. 76, apud, HADOT, 1999a, n. 9, 218). Entrementes, esta não é a forma geral dos textos e do ensino filosófico nas instituiçōes atenienses. Com efeito, a desaparição das Escolas filosóficas de Atenas, provavelmente em decorrência da tomada da cidade por Silas, em 86 a.C., e o estabelecimento de novas Escolas na Bacia Mediterrânea, tanto em cidades do Ocidente, como do Oriente, inaugura uma nova fase na história da filosofia. Com o escopo de afirmar a fidelidade aos antigos fundadores das tradiçôes, que haviam criado as instituições atenienses, nas quais se perpetuou uma tradição oral que não tem continuidade fora dos muros das antigas Escolas, as novas Escolas veem-se compelidas a comentar os textos dos fundadores. Assim é que a filosofia passa a ter a forma de comentário. 
influência pitagórica ${ }^{34}$, que tinha um elemento importante: o segredo. As verdades fundamentais não podiam ser difundidas para todos; daí as doutrinas serem transmitidas oralmente no pitagorismo, ou ainda, formuladas de modo enigmático e simbólico; o qualificativo mais comumente usado para designar as doutrinas orais pitagóricas era "símbolo" (BRISSON, 1996, 81)35. Assim, dentre os médio-platônicos, os termos que designam um sentido subentendido, enigmático ou simbólico, são aplicados tanto à interpretação de mitos, como às religióes de mistérios, e à própria filosofia de Platão e Pitágoras. Já em Plutarco verifica-se que falar através de enigmas é falar de modo pitagórico (PLUTARCO, Sobre Ísis e Osíris, 9 -10; Moralia, 354 b-e). Ademais, cabe notar que para esse platonismo fortemente influenciado pelo pitagorismo, no qual a filosofia apresenta-se como uma possibilidade de ascender de um nível inferior de conhecimento, para outro, superior, estabelecem-se novas relaçóes com respeito ao mundo dos deuses, que é assimilado ao inteligível. Donde o emprego de novos termos técnicos designando a interpretação de mitos (BRISSON, 2004, 31).

34. É então que a influência pitagórica, que se fez sentir fortemente na antiga Academia, com Espeusipo e Xenócrates, torna-se determinante no platonismo. As modalidades históricas dessa influência permanecem obscuras. Entretanto, percebe-se que ela se impõe como um dos pressupostos filosóficos de Plutarco (BRISSON, 1996, 81). Na mesma linha de raciocínio pode-se consultar Pépin (1976, 81 ss).

35. Segundo Brisson, a relação com a escrita também era problemática na tradição platônica, donde a aproximação com o pitagorismo foi facilitada. 


\section{TERMOS DA FAMÍLIA DE AÎNOS EM PLOTINO}

O mito em Plotino, por ser uma imagem, se exprime por enigmas e metáforas, que é preciso interpretar. Não por acaso, é associado aos mistérios, onde imagens de diferentes tipos - cênicas e plásticas - são interpretadas com o auxílio das palavras do sacerdote. Filologicamente, esse caráter enigmático e misterioso do mito é claramente expresso pelo termo que talvez seja o mais recorrente no campo semântico do mito. Trata-se de ainittetai e seus cognatos. Porém, se, por um lado, esses termos permitem entrever uma continuidade entre Plotino e Plutarco, por outro, nas Enéadas, os derivados de aînos permitem estabelecer um nexo entre a exegese dos mitos e dos Antigos. Buscando as ocorrências dos termos da família de ainnos ${ }^{36}$, verifica-se que aparecem nos tratados nas seguintes situações: 1) em um contexto de exegese alegórica de mitos; 2) referindo-se ao modo como se expressaram Platão e Pitágoras; 3) em uma ocorrência, refere-se a uma escolha da alma (III, 4 [15] 5, 3) ${ }^{37}$.

Assim, quanto ao primeiro ponto, nota-se que nove passagens concernem à exegese de mitos. Destas, em quatro, figura o termo mito (IV, 3 [27] 14, 5; I, 6 [1], 8, 11; V, 8 [31] 4, 26; V, 1 [10] 7, 33). Em três,

36. No total, encontram-se 16 ocorrências, registrando-se as seguintes formas: ainittesthai, ainittetai, aninittómenoi, ainitómenos, ainittoménou, ainittontai, ëinigménon, èiníttonto, ainíxeōs, aínigma.

37. Este ponto não parece contribuir para a questão central, motivo pelo qual não será estudado. 
percebe-se a associação dos mitos aos mistérios e iniciaçōes (III, 6 [26] 19, 26; I, 6 [1] 6, 3; V, 1 [10] 7, 33). Em uma, o mito é verificado por uma alusão ao Banquete de Platão (III, 5 [50] 2, 24). Além dessas, duas outras mencionam metaforicamente um templo, interpretando o que representam as esculturas na entrada do templo ${ }^{38}$. Quanto ao segundo ponto, constitui uma questão subsidiária à problemática central, mas não desprezível. Com efeito, o segundo ponto, em que os termos da família de aînos referemse ao modo como Platão e os pitagóricos se expressaram, propóe a relação entre a exegese dos mitos e a dos Antigos filósofos: o uso de um mesmo grupo de termos para designar, sejam os mitos, sejam os discursos dos Antigos, permite indagar se os dois tipos de discurso situam-se em um mesmo plano. Isto é, tanto um, como outro, tem subentendida a verdade sob as palavras; diante deles, o exegeta deve desvelar a verdade, ou, por outra, solucionar o enigma. Todavia, é preciso observar que, dentre todos os discursos, o de Platão ocupa um lugar especial nas Enéadas.

\section{PLATÃO E OS ANTIGOS FALAM POR ENIGMAS}

De fato, as Enéadas constituem-se em um diálogo com a tradição, sendo que uma parte desse diálogo se dá com a tradição mítica. Ora, é sabido que, para os

38. As duas ocorrem na mesma frase, ver VI, 9 [9] 11, 27-28. Ambas foram estudadas no primeiro capítulo deste livro. 
neoplatônicos, a tradição orbita em torno a dois eixos que se complementam: por um lado, a interpretação do legado platônico; por outro, a interpretação do legado mítico, que não contradissesse os ensinamentos que encontravam em Platão (ZAMORA, 2000, 91). De um modo geral, isso decorre da crença em uma verdade única, a qual, embora tenha sido expressa com maior acribia por Platão, já havia sido entrevista pelos Antigos e pelos teólogos, que são os autores das teogonias e cosmogonias ${ }^{39}$.

Pode-se discorrer, ainda que resumidamente, sobre a relação entre a exegese dos mitos, a dos filósofos Antigos, e a de Platão, a partir de uma perspectiva histórica, tendo em vista três aspectos característicos de um filósofo do terceiro século, sendo dois gerais, relativos à formação e ao método do comentário, e um mais particular, concernente à leitura de Platão por Plotino. Assim, em primeiro lugar, é importante observar que, quanto à formação geral, para poder entrar no programa de ensino das Escolas filosóficas da Época Imperial, que comportava três partes, a dialética (ou lógica, no caso dos estóicos), a física e a ética, era mister atender a algumas condições preliminares. Uma delas era possuir uma formação em retórica, tão profunda quanto possível, pois se valorizavam bastante os métodos psicagógicos obtidos pela retórica. Ora, o estudo da retórica exigia uma formação anterior em gramáti-

39. "A verdade é, segundo Plotino, originária. Ao passado ligam-se os mitos e toda espécie de belas coisas divinas que foram transmitidas aos homens. É porque pertencem ao passado que tiveram conhecimento da verdade" (CHARRUE, 1993, 24). 
ca, que nessa época consistia no estudo de um cânone de poetas. Para os neoplatônicos, era muito valioso o conhecimento de poetas considerados divinamente inspirados, como Homero e Hesíodo, porquanto a interpretação de mitos desempenhava um papel importante na sua filosofia (HADOT, 2005, 416-417).

Dessarte pode-se mencionar o segundo aspecto geral, que concerne ao comentário de textos. Por si, o substantivo latino com-mentarium, assim como o verbo grego que está na sua origem, ex-égeîsthai, indicam que o pensamento é colocado em relação com um suporte preexistente, ou seja, pensa-se com, pensa-se a partir de. O texto, que é o suporte, é reconhecido como autoridade indiscutível ${ }^{40}$. Nesse sentido, Plotino fornece um testemunho emblemático: trata-se de uma passagem bastante conhecida das Enéadas onde ele se situa como exegeta das doutrinas do passado:

40. Aqui estão sendo seguidos alguns pontos expostos por GouletCazé, na apresentação de um volume concernente ao comentário na Antiguidade e na Idade Média. Em uma frase, a autora sintetiza o que está em questão na prática exegética antiga e medieval: "O ato de comentar aparece, em suma, como um ato complexo, ao longo do qual se encontram confrontadas duas realidades: por um lado, um ato acabado e constrangedor, o texto, núcleo duro incontornável, que adquiriu uma espécie de objetividade, e por outro lado, um pensamento em ato que reage face a este produto acabado, elaborando um texto novo, o percurso posto em obra podendo ir da exegese mais literal à interpretação mais alegorizante, da explicação mais tradicional ao comentário mais inovador" (GOULET-CAZÉ, 2000, 7). 
Estes discursos não são novos e não datam de hoje. Eles foram proferidos faz muito tempo, mas de modo não explícito ( $m e ̀$ anapeptaménōs). Hoje, nossos discursos são os de exegetas (exégètás) destas antigas doutrinas cuja antiguidade nos é testemunhada pelos textos de Platão (V, 1 [10] 8, 10-14).

Observe-se que esta é a única ocorrência do termo exēgètás nas Enéadas. De fato, esta palavra era um termo técnico do vocabulário dos alegoristas, designando a tarefa de decifrar um tipo de discurso que não é explícito, quer dizer, que é enigmático, misterioso (PÉPIN, 1973, 497). Com efeito, antes de ter sido adotada pelos filósofos, a exegese foi praticada pelos alegoristas de Homero, pelos retores e pelos gramáticos. Essas tradições foram úteis aos exegetas filósofos, de tal modo que as regras da exegese, tendo sido codificadas pela retórica, encontram-se de certo modo na interpretação dos textos filosóficos ${ }^{41}$. Entrementes, não se pode obliterar que os filósofos exegetas do século III d.C., como Plotino, consideram que a verdade encontra-se mais exatamente expressa nos textos

41. "A retórica havia codificado as regras da exegese dos textos, em relação com a interpretação do direito. A propósito da controvérsia concernente ao direito, distinguiam-se quatro questôes: é preciso deter-se no texto ou na intenção daquele que o escreveu? Qual texto reter quando dois textos são contraditórios? Pode-se, raciocinando sobre dois textos, obter uma conclusão que não está no texto? Tais questóes encontram-se evidentemente na interpretação de textos filosóficos" (HADOT, 1987, 19). 
do fundador da tradiçãao a qual seguem - no caso de Plotino, trata-se dos textos de Platão. Dessarte, "a arte do exegeta consiste em saber conciliar a letra do texto com o que o intérprete considera como a verdade, contida e oculta no texto" (HADOT, 1987, 19). Claro que isso comporta uma dose de contrassenso, mesmo que involuntariamente, ou em outros termos, o exegeta não poucas vezes segue um curso distinto daquele que o texto comentado apresentava. E é desse movimento, próprio à interpretação, que surgem novos pensamentos. Como observa Santa Cruz (1997b, 1 ss.), Plotino considerava-se e era considerado por seus pares como um platônico, mas sua fidelidade à tradição não o impediu de construir uma síntese profundamente pessoal. A originalidade de Plotino reside, justamente, nas interpretações dos textos que ele utiliza, nas críticas que ele faz e nas correções que introduz. Plotino inova, diz a estudiosa, mas, ao mesmo tempo, ele é um tradicionalista, pois toda inovação é proposta à condição de estar em acordo com a tradição. Esse movimento sinfônico pode ser percebido, por exemplo, quando sua teoria das três realidades superiores é apresentada como sendo exegese da filosofia anterior. Este é, aliás, um claro exemplo da exegese que Plotino faz das três primeiras hipóteses do Parmênides de Platão.

Em uma passagem bastante conhecida, V, 1 [10], 8, 24-27, Plotino evoca o diálogo Parmênides de Platão, dizendo que este apresenta a unidade de cada nível de realidade de modo mais exato (akribésteron) que o próprio Parmênides: o primeiro Um é propriamente 
$u^{42}$. O segundo um é um-múltiplo ${ }^{43}$; e o terceiro um é um e múltiplo ${ }^{44}$. Este acordo entre as hipóteses do Parmênides e o Um, o Intelecto e a Alma não tem nada de evidente; entretanto, é importante observar o percurso interpretativo de Plotino: ele trata de associar noções platônicas aos três níveis de realidade suprasensível, tal como ele a concebe. A essa prática exegética conecta-se outra, recorrente nos tratados, segundo a qual Plotino concilia determinados conceitos de Platão, que nos diálogos não possuem nenhum vínculo uns com os outros. Para Plotino, todavia, tais conceitos representam aspectos diversos de uma mesma entidade metafísica. Possivelmente o exemplo mais impressionante desse acordo entre textos platônicos é a fusão do Um da primeira hipótese de Parmênides com o Bem epékeina tés ousías da República 509 b-d $\mathrm{d}^{45}$.

42. Alusão à primeira hipótese do Parmênides: o Um não é um todo nem tem partes se é um (PLATÃO. Parmênides, 137 c - 142 a).

43. Refere-se à segunda hipótese, na qual o um é múltiplas coisas (PLATÃO. Parmênides, 144 e - 151 e). A segunda hipótese prossegue tentando mostrar que o um - múltiplo está no tempo, mas nisso Plotino não segue Platão, motivo pelo qual se pode considerar que se trata de uma alusão parcial à segunda hipótese.

44. Trata-se agora da terceira hipótese, na qual o um é um e múltiplas coisas (PLATÃO. Parmênides, 155 e - 157 b).

45. O que aqui é considerado um acordo entre diálogos, Lacrosse (1994, 32) denomina "quase-sincretismo". O conceito de sincretismo sugere uma síntese entre elementos díspares, e mesmo originários de doutrinas filosóficas distintas. Nesse sentido, parece exagerado aplicar este termo ao procedimento exegético de Plotino. A noção de exegese combinatória, que possui um caráter investigativo, parece mais adequada à metodologia plotiniana. Entretanto, tal noção não exclui a metáfora da sinfonia, que ten- 
De fato, nos diálogos não parece haver nenhuma identificação entre um conceito e outro: o primeiro Um do Parmênides parece ter um caráter totalmente transcendente, independentemente do fato de ser apenas uma hipótese lógica ${ }^{46}$ ou uma realidade henológica, como interpreta Plotino; ao passo que o Bem da República constitui uma das ambiguidades fundamentais de Platão, pois, mesmo sendo transcendente, isto é, além da essência, ele ainda é uma Ideia. Portanto, associar o Bem ao Um possibilita a Plotino ignorar essa diversidade, conciliando os textos platônicos. Outro exemplo bastante expressivo do tipo de interpretação praticada por Plotino, tendo por alvo textos de Platão, figura em V, 1 [10] 8, 1-8:

Eis a razão por que Platão diz haver três realidades: todas as coisas em torno ao rei de todas as coisas - chama-as primeiras - o segundo em torno às segundas e o terceiro em

ta expressar a harmonia de uma composição, a qual, no caso, é o texto filosófico de Plotino, em dois planos: naquele em que ele concilia diferentes diálogos de Platão, e naquele em que ele realiza uma espécie de síntese entre diversas fontes originárias da tradição grega. Assim, as fontes antigas se encontram na composição dos tratados, seja como objeto de crítica ou de correção, ou, como é muito frequente, sendo ajustadas ao que Plotino considera a verdade dos textos platônicos.

46. Em seu Comentário sobre o Parmênides, Proclo, diádoco platônico em Atenas, no século V d.C., retraça a história da interpretação da segunda parte do diálogo, recusando uma interpretação conhecida de que Platão o teria escrito sem quaisquer referências ao real, como um simples exercício lógico a fim de refutar Zenão de Eléia no seu próprio terreno, a lógica (In Parm. 631, 15 - 633, 12). 
torno às terceiras ${ }^{47}$. Diz também que há um pai da causa ${ }^{48}$, chamando causa o Intelecto ${ }^{49}$; pois, para ele, o Intelecto é o demiurgo. Ele afirma que $<$ o demiurgo $>$ cria a Alma naquela cratera ${ }^{50}$. E como a causa é o Intelecto, por pai entende o Bem, ou seja, o que está além do Intelecto e além da essência ${ }^{51}$.

Esta passagem exemplifica uma prática assaz frequente no que tange à exegese dos textos de Platão. Plotino retira palavras, frases ou parte de frases de diferentes diálogos platônicos, e as aglutina conferindo ao conjunto um sentido exógeno ao do contexto em que essas passagens figuram originalmente. Com efeito, Plotino parece fazer as seguintes correspondências: ao Um correspondem em Platão o Bem (República), o rei de todas as coisas (Carta II), e o

47. "Em torno ao rei de todas as coisas encontram-se todas as coisas; é em vista dele que tudo existe e é ele que é a causa de absolutamente tudo o que é belo. Em torno ao segundo, encontram-se as coisas de segundo nível; e em torno ao terceiro, as coisas de terceiro nível" (Carta II, 312 e 1-4).

48. “(...) e que é o soberano pai do chefe e da causa” (Carta VI, $323 \mathrm{~d} 4$ ).

49. “(...) afirmava-se que o Intelecto é a causa ordenadora e universal de todas as coisas" (Fédon, 97 c 2 - trad. Azevedo, modificada). Ver também Filebo 30 c, onde Platão identifica a causa e o Intelecto.

50. "Havendo assim falado $<$ o demiurgo $>$, retomou a cratera em que antes compusera por uma mistura a alma do mundo" (PLATÂO, Timeu, 41 d 4-5 - trad. Nunes, modificada). Ver também Timeu, $34 \mathrm{~b}-35 \mathrm{~b}$.

51. “(...) apesar de o bem não ser uma essência, mas estar acima e para além da essência, pela sua dignidade e poder” (PLATÃO, República, 509 b 9 - trad. Pereira). 
pai da causa (Carta VI). Ao Intelecto correspondem o demiurgo (Timeu) e a causa (Fédon e Filebo). À Alma, a alma do mundo (Timeu $)^{52}$.

É mister observar, contudo, que Platão é mais exato que os Antigos, portanto, vista sob este prisma, sua autoridade parece residir na acribia. $\mathrm{O}$ texto platônico serve como um instrumento de medida, ou como uma baliza, que guia a exegese dos Antigos. Porém, como bem observou Éon, do ponto de vista da exegese plotiniana, Platão também é exegeta dos Antigos; é nos seus escritos que a autoridade daqueles filósofos funda seu direito. Mas o próprio texto platônico deve ser alvo de uma exegese, pois ele é enigmático, como os mitos e os discursos dos Antigos, dos quais, entretanto, explicita o conteúdo (ÉON, 1970, 263-264). Não parece fortuito, portanto, observar que das dezesseis ocorrências de termos da família de aînos nas Enéadas, cinco refiram-se ao modo como expressaram-se Platão e Pitágoras. Destas, duas nominalmente (VI, 2 [43] 22, 13-14; IV, 8 [6] 1, 21-22). Uma mencionando os Antigos, mas aludindo a Platão (VI, 8 [39] 19, 12-14). Outra, aludindo ao Timeu 35 a 1-4, sem nomear Platão, nem o diálogo (IV, 2 [4] 2, 49-52). Finalmente, uma passagem refere-se ao discurso de Pausânias no Banquete 180 d 7, onde está em questão a genealogia de Afrodite (III, 5 [50] 2, 24).

Diante dessas passagens, é lícito indagar: o que significa qualificar Platão como enigmático? Sob determinado prisma, isso sugere que Plotino lê o texto de Platão como um oráculo. Com efeito, Schroeder

52. Desenvolvo um pouco mais este tema da exegese dos Antigos em OLIVEIRA (2007, 467-479). 
(2002, 27) nota que o verbo ainittesthai refere-se a oráculos, mas igualmente à função oracular da linguagem quanto ao mundo inteligível, não suscetível de ser aberto na fala discursiva. Plotino usa este verbo e seus cognatos na interpretação do texto de Platão; assim, o texto platônico pode ser considerado oracular, porque Plotino o vê como contendo uma profundidade não aparente na superfície do pensamento. Aqui, mais uma vez percebe-se um ponto de tangência entre o mito e a exegese platônica. Como o mito, nesse caso, o pensamento de Platão se dá sob forma oracular, por conseguinte, exige uma hermenêutica (ÉON, 1970, 264) ${ }^{53}$. Todavia, é essencial observar que a tarefa do exegeta não consiste apenas em recolher o dogma platônico, mas, sim, em construí-lo.

Além disso, diante das divergências que Plotino encontra, ao confrontar diferentes passagens dos diá$\operatorname{logos}^{54}$, ele parece reconhecer que Platão não tem uma

53. "Pode-se dizer que no fundo a atitude de Plotino consiste em tratar o texto platônico e em geral a doxografia como oráculos, e a se fazer o interprete deles". E ainda: "Tal é a virtude do enigma: ele tem valor de incitação, porque significa a verdade, mas sem que se tenham razóes para pensar que ele a encerra em suas malhas discursivas; a fórmula não contém o objeto, ela não o dá; ela apenas indica a regra a seguir para se dirigir a ele. Sua autoridade é, na realidade, um apelo à nossa iniciativa” (ÉON, 1970, 275).

54. Plotino expressa tais dificuldades. Por exemplo: "O que nos diz este filósofo? Parece que ele não diz sempre a mesma coisa, de modo que se possa ver facilmente sua interpretação" (IV, 8 [6] 1, 26-28). "Com isso mostra-se, de um lado, o assunto em si na sua posição como dificilmente solucionável, de outro lado, cresce nas palavras de Platão uma dificuldade ainda maior, ou pelo menos não menor" (IV, 4 [28] 22, 10-12). 
única solução definitiva para um mesmo problema (CHARRUE, 1993, 29). Assim, à noção de enigma associa-se a de aporia, que, para Plotino, constitui, no mais das vezes, um ponto de partida ${ }^{55}$. Nisso, a noção de enigma, de certo modo, se distingue nos mitos e nos discursos de Platão, pois os mitos não se apresentam como aporias. Por outro lado, uma consequência decorrente da fala enigmática de Platão, é atribuir a ele conceitos que não são seus, ou seja, Plotino elabora respostas próprias aos enigmas platônicos. Outrossim, pode-se indagar sobre o que significa a noção de verdade originária, a qual parece estar na base da postura exegética de Plotino. Charrue $(1993,25)$ atenta para esse problema e sugere a seguinte solução: não se trata de uma verdade hipermetafísica e de nível quase religioso. Isto é, as opiniões dos Antigos e, igualmente, as de Platão, não constituem uma autoridade absoluta à qual é preciso obedecer sem reflexão. Com efeito, segue o comentador, a verdade é epistemológica. Ora, a posição de Charrue é pertinaz, assim como a de Éon (1970, 262-263), que tende para o mesmo lado. Ambos, em suma, consideram que essa verdade epistemo-

55. Observe-se ainda que Plotino talvez também esteja ecoando Platão: "E notaremos que, se essas aporias são chamadas por Plotino de enigmas, não é por não sei que gosto irracional pelo mistério. Não se pode esquecer que Platão póe este termo na boca de Sócrates para qualificar as respostas do interlocutor ou as soluçóes propostas por tal ou tal dentre os seus predecessores" (ÉON, 1970, 274). 
lógica resulta ora do confronto, ora do acordo entre diferentes opiniōes ${ }^{56}$.

Mas diante disso tudo resta saber se o mito e os discursos dos Antigos, uns e outros enigmáticos, desempenham a mesma função nos textos das Enéadas. Do que se viu até aqui, parece que, por um lado, sim, pois, sendo discursos, ambos propōem um equivalente sensível da unidade. Mas, por outro lado, não. Isso implica, evidentemente, aceitar, se não uma polissemia, ao menos certa flexibilidade no uso dos termos da família de aînos. Ademais, denota uma variedade de procedimentos exegéticos no cerne das Enéadas, além da já mencionada variedade de procedimentos linguísticos. Por um lado, os mitos, embora estejam abertos à interpretação, não estão sujeitos à crítica, nem ao confronto. Por outro, eles nem sempre são lidos através dos diálogos de Platão, como ficou demonstrado no estudo da genealogia divina. Além disso, as figuras míticas possuem uma relação muito peculiar com o tempo, que as doutrinas antigas não parecem possuir.

56. Outra via é apresentada por Lacrosse (2003a, 39), que avança em uma direção um pouco diferente, tentando mostrar que Plotino não busca a verdade histórica dos Antigos, mas uma espécie de verdade noética, expressa dianoeticamente pelos escritos antigos. Neste caso, o discurso filosófico é um desenvolvimento de ideias e de expressóes, cujo objetivo é fazer atingir a verdade encarnada pelo Intelecto. Lacrosse chega a essa conclusão associando a prática hermenêutica que se pode divisar nos tratados à doutrina de Plotino. Entretanto, o conceito de verdade noética não parece invalidar o de verdade epistemológica, haja vista que, em ambos os casos, o exegeta é levado a desenvolver discursivamente os conceitos que tem em vista. 
E ainda, os mitos parecem possuir um certo estatuto de imagem, que os aproxima das representaçóes plásticas, o que não ocorre com os discursos dos Antigos. Falta ainda aludir ao último subgrupo de termos que recobrem o campo semântico do mito, para verificar a proximidade dos mitos com os mistérios, outro ponto no qual os mitos não tangenciam os discursos antigos.

\section{MÍSTICA: INTERPRETAÇÃO ALEGÓRICA DE MITOS E MISTÉRIOS}

O vocabulário dos mistérios emerge nas Enéadas associado aos mitos, parecendo indicar sua função anagógica. Mas antes de analisar isso, e para evitar um anacronismo, ou ainda, uma inexatidão concernente ao vocabulário do mito, é mister explicar que, no âmbito deste trabalho, mística não é um termo aplicável à união da Alma com o Intelecto e o Um, pois é tomado no sentido em voga à época de Plotino, designando um certo tipo de interpretação de mitos. O problema deste termo, entretanto, é que certa tradição interpretativa o utiliza para designar a busca por uma união íntima entre o homem e Deus, ou o primeiro Princípio, ou ainda Um, ou Totalidade, segundo a terminologia com que se a nomeie. Esse sentido parece ter vindo a lume a partir dos escritos do Pseudo-Dionísio Areopagita, por um desenvolvimento complexo de metáforas platônicas e cristãs (BURKERT, 2003, 10).

Portanto, é por uma via retrospectiva que muitas vezes o termo "mística" é aplicado anacronicamente ao mundo grego, e a designação "mística do Um” é atri- 
buída comumente ao movimento filosófico chamado neoplatonismo, do qual Plotino é considerado o primeiro expoente. Embora Plotino descreva a união da alma com o Um e com o Intelecto, ele em nenhum momento utiliza o termo "mística" para descrever tal união. Os caminhos que levam a alma ao Um são a beleza, o amor e a filosofia. Porém, é fundamental observar, por um lado, que estes caminhos dificilmente podem ser entendidos cada qual como uma via exclusiva. Efetivamente, em Plotino há diferenças quanto às descriçōes dos caminhos, que permitem compreender como válida tanto esta possibilidade, na qual a via da beleza é propedêutica à do amor, que, por sua vez, é anterior à da dialética. Mas também é possível aceitar a possibilidade de que há um caminho erótico, no qual a beleza é não somente o ponto de partida, mas o elemento que baliza o caminho para a alma, a qual se torna pura visão amorosa do princípio, sem necessariamente tornar-se dialética ${ }^{57}$. Não obstante, há um traço comum a esses caminhos: a virtude.

Portanto, ciente deste uso, se propóe aqui uma espécie de correção, partindo de um fato conhecido: o termo grego mystikós está ligado às antigas religiōes de mistérios e, em Plotino e na filosofia da Era Imperial,

57. Há dois tratados em que é possível identificar o amor como uma via de conversão, I, 6 [1] e III, 5 [50]. Mas este assunto é controverso e exorbita dos limites do presente estudo, motivo pelo qual não será aprofundado aqui. Alguns pontos polêmicos concernentes ao percurso da alma nos tratados I, 6 [1], Sobre o belo, e I, 3 [20], Sobre a dialética, foram observados em Oliveira (2005). 
de modo geral, a um certo tipo de interpretação de mitos (BRISSON, 2005, 61-72). É nesse sentido que se deve entender o vocabulário dos mistérios o qual se encontra no campo lexical do mito.

Há uma única passagem das Enéadas onde ocorre o advérbio mystikôs.

Se a mãe dá algo ao seu filho, não é enquanto matéria, mas porque ela é igualmente forma. Seguramente só a forma engendra, e a outra natureza (= a matéria) é estéril. Eis por que, suponho, os antigos sábios, falando com palavras encobertas (ainittómenoi), como se faz nos mistérios (mystikôs) e nas iniciações (teletaîs), representam o antigo Hermes com o órgão da geração sempre em atividade, para mostrar que a razão que depende do inteligível é genitora das coisas sensíveis, enquanto a matéria permanece estéril, sempre representada cercada de eunucos (III, 6 [26] 19, 23-30).

Como se pode perceber trata-se da interpretação alegórica de Hermes itifálico em um contexto cosmológico ${ }^{58}$. Hermes representa a parte inferior da alma do mundo, que está sempre a implantar razóes na matéria. Esta, privada de vida, e desprovida da capacidade de gerar é assimilada a Cibele, a Grande

58. Esta interpretação de Hermes é de origem estóica. Ver CORNUTO, Compêndio de teologia grega, 23. Há uma outra referência a Hermes nas Enéadas, em II, 3 [52] 12, 23, também em contexto cosmológico, porém representando o planeta Mercúrio. 
Mãe, de quem os sacerdotes são eunucos voluntários (BRISSON, 2005, 65). Embora na passagem em questão não apareça expressamente seu nome, é consabido que a deusa mãe, seguida por eunucos, era Cibele. A Mater Magna da Ásia Menor era chamada simplesmente Méter, Mãe, pelos gregos, que também a chamavam de Kybéleia ou Kybéle, originado de seu nome frígio, Matar Kubileya, ou, mais seguidamente, Méter Oréia, Mãe das Montanhas, muitas vezes com o nome da montanha adicionado, por exemplo, Mètèr Idaïa ${ }^{59}$.

$\mathrm{Na}$ Antiguidade, além do culto à Mater Magna, havia diversos que se apresentavam como mistérios, como, por exemplo, os mistérios de Elêusis, também chamados simplesmente de mistérios, que eram consagrados às "Duas Deusas": Deméter, deusa dos cereais, e sua filha Perséfone, que, no dialeto ático, era seguidamente chamada Core, "a virgem" ${ }^{60}$. Esses mistérios eram realizados em Atenas e supervisionados pelo arconte-rei. O mito é bem conhecido: conta como Core foi raptada por Hades e como sua mãe empreen-

59. O título oficial do culto a ela em Roma era Mater Deum Magna Idaea, donde a abreviação Mater Magna. O culto foi introduzido oficialmente em Roma em 204 a.C. durante a guerra com Aníbal, sob ordem de oráculos, e se espalhou a partir daí. Uma das formas mais espetaculares do culto era o taurobolium, cuja existência é atestada a partir do século II d. C. O iniciado ficava acocorado em uma fossa coberta por uma grade de madeira, sobre a qual se degolava um touro. Ele era inundado pelo sangue que corria do animal (BURKERT, 2003, 8). Considerando o nome oficial, pode-se deduzir que Deum é uma abreviação de Deorum e, portanto, o nome do culto seria algo como Grande Mãe dos Deuses do Monte Ida.

60. Ou ainda, menos frequentemente, Pherephatta. 
de a busca. Hades, o deus do mundo subterrâneo dos mortos, concede que Core passe um período limitado na superfície da terra, precisamente em Elêusis. Era, portanto, lá que, na passagem do verão para o outono, os atenienses celebravam a parte mais importante dos mistérios, chamada grandes mistérios, que consistiam na iniciação. Pelo que se sabe, duravam dez dias, e, na véspera do início das cerimônias, transportavamse de Elêusis a Atenas os objetos sagrados (ierá), que eram guardados fechados em cistas, no Anáktoron, no coração do Telestêrion, e depois levados em procissão até Eleusino, ao sopé da Acrópole. Durante os dias seguintes, diversos ritos e celebrações tinham lugar, até que, no sexto dia, procedia-se à iniciação propriamente dita, cujos ritos compreendiam três elementos: as representaçōes dramáticas (drómena), possivelmente sobre o rapto de Coré e a trajetória de Deméter para reencontrá-la; os objetos sagrados que eram mostrados (deiknýmena) pelo sacerdote, ou hierofante, literalmente, aquele que mostra os objetos sagrados. Finalmente, os comentários (legómena) do sacerdote sobre o que foi mostrado. Com efeito, os legómena acompanhavam as cenas e os objetos mostrados aos assistentes. Não formavam um discurso seguido, mas pelo que se pode saber, consistiam em fórmulas rituais que instruíam o iniciado ${ }^{61}$.

61. Foucart $(1999,420)$ assegura que um único exemplo dessas fórmulas chegou aos dias atuais: "A divina Brimo pariu Brimos, criança divina”. 
Observe-se que no item $k$ do quadro concernente ao vocabulário do mito, encontra-se uma menção aos sacerdotes e teólogos: “(...) e mais uma vez testemunham esse raciocínio sacerdotes e teólogos, que identificam Hera a Afrodite e chamam astro de Hera ao astro de Afrodite que há no céu" (III, 5 [50] 8, 22 - trad. Baracat Jr.). Nessa passagem, Plotino apela tanto à voz dos mistérios, como à poesia, para poder identificar Hera e Afrodite e, assim, justificar as bodas de Afrodite e Zeus, ou seja, da Alma e do Intelecto. Possivelmente Plotino estivesse referindo-se a interpretaçōes daqueles mitos conhecidas à sua época. A associação entre o planeta Hera com Vênus (Afrodite) parece ter sido introduzida na Era Helenística pelos caldeus, astrônomos babilônios da época selêucida, ou por seus discípulos gregos ${ }^{62}$. Outrossim, o nome Hera para o planeta Vênus foi atestado em diferentes fontes (TIMAEUS LOCRUS, De natura mundi, 96e; Ps. ARISTOTELES, De Mundo, 392 a 26). Essa terminologia também era associada ao culto da deusa síria Baltis, identificada pelos gregos tanto com Afrodite, como com Hera (WOLTERS, 1972, 22-23).

Paul Foucart $(1999,355)$ enumerou e explicou o vocabulário que designava as diversas partes dos mistérios. Partindo desse estudo, pode-se verificar o que significam certas expressões concernentes aos mistérios, recenseadas nos quadros sobre o vocabulário do

62. O nome "caldeu" aplica-se tanto aos povos da região da Caldéia, como àqueles astrônomos, que em hebraico eram chamados "casdim". 
mito. No mesmo episódio em que aparece Hermes, no qual se encontra a palavra mística, também verificase teletâ̂s. Ora, teletế nesse âmbito, refere-se de modo geral aos ritos relativos às iniciaçôes. Prevalece na prosa, designando as cerimônias solenes, normalmente acompanhadas de comunicação misteriosa; donde, torna-se sinônimo de iniciação. Mystếrion, que ocorre em $d$ no quadro, é a mais geral de todas as expressões desse vocabulário, designando as cerimônias acessíveis somente aos iniciados. É curioso notar que o termo mystếrion conduz ao verbo mû̀, o qual em Homero significa cicatrizar um ferimento, ou fechar os olhos (HOMERO, Ilíada, XXIV, 420, 637) ${ }^{63}$. Coerentemente com esses sentidos, uma tradição lexicográfica e escoliástica propôs a seguinte etimologia: são mistérios porque os iniciados cerram os lábios e não falam com nenhum não-iniciado (TZETZES, ad Aristofane, $R a$ $=$ Frag Eleusi E 28 Scarpi) ${ }^{64}$. Os mistérios eram cercados de segredos ${ }^{65}$; os deuses não se mostravam sob forma visível aos mortais. Mesmo algumas esculturas ficavam trancafiadas em templos que não se abriam, ou que raramente as mostravam. O caráter secreto dos rituais era expresso por dois adjetivos, árēta e apórrèta, os quais significavam, respectivamente, o que é indi-

63. Os dois sentidos do termo encontram-se igualmente no grego posterior a Homero.

64. Sobre a etimologia do termo "mistério" e de outros vocábulos dos mistérios, ver SCARPI, 2004, XVI ss.

65. "O segredo dos mistérios dá uma ideia majestosa da divindade e nos lembra de sua natureza que se oculta aos nossos sentidos" (STRABÃO apud FOUCART, 1999, 359). 
zível e o que é interdito, mas que parecem ter sido usados de modo intercambiável, quase entendidos como sinônimos (SCARPI, 2004, XVII). É já sabido que as iniciações nos mistérios continham uma parte na qual as encenaçōes e os objetos eram interpretados. Donde, a alegoria, em um contexto religioso, é chamada "mística". Além disso, na época helenística, esse termo parece já ter substituído o de alegoria (BURKERT, 2003, 74).

Assim, como diz Brisson (2005, 64 ss.), mystikôs e seus derivados são utilizados para designar um tipo de interpretação de mitos e de ritos que têm por modelo a prática dos mistérios. Uma interpretação deste tipo tem por escopo mostrar como os poetas, que parecem falar da realidade sensível, na verdade evocam a realidade inteligível, que é objeto da filosofia. Se a filosofia se encontra assimilada a um mistério, é porque ela muda as relações do filósofo com a realidade: o sensível aparece como uma imagem da realidade verdadeira, o inteligível, que desempenha o papel de modelo.

Assim sendo, associado a um tipo de exegese mistérica de mitos, nas Enéadas, o termo mística sugere o aspecto anagógico do mito. Mas os mitos não constituem caminhos de ascensão capazes de cumprir todas as etapas até a união. Mística, em senso estrito, portanto, afigura-se apenas como um meio de indicar, através da interpretação dos mitos, o invisível.

Conforme o que foi visto neste capítulo, portanto, tem-se que as figuras míticas aludem a algo para além delas e indicam seu objeto. Quando interpretadas, a exegese é mística, ou seja, tem um aspecto anagógico semelhante ao das iniciaçóes nos cultos de mistérios. 


\begin{abstract}
Além disso, com os discursos dos Antigos elas constituem um dos pilares estruturais da filosofia de Plotino, mas diferentemente deles, as figuras são representações assimétricas do invisível, no que se assemelham a pinturas. Finalmente, as figuras míticas estão associadas à faculdade da imaginação. Todos esses aspectos são a base das análises de diversas figuras míticas, nos dois capítulos seguintes.
\end{abstract}


7.

\section{FIGURAS DA ALMA}

$\mathrm{D}$ entre as figuras míticas que não se encontram em um esquema genealógico nos tratados, parte considerável simboliza a Alma em algum dos seus aspectos ou partes. Serão aqui analisadas quatro figuras: Dioniso, Prometeu, Pandora e o personagem anônimo, com as quais é possível discorrer acerca da Alma superior, da descida da alma do mundo e das almas individuais ao sensível, do papel da providência e, finalmente, das almas que se desviam do inteligível. Assim, do ponto de vista da teoria da alma, o estudo dessas figuras permite compreender, sob diferentes ângulos, a descida das almas ao mundo sensível. Quanto ao estatuto do mito, no decorrer das análises, serão sublinhados aspectos importantes do mito nas Enéadas, tal como o caráter alusivo e o caráter imagético do mito, que se depreende do vocabulário empregado por Plotino para caracterizar esses mitos, composto por termos como ainittesthai, 
emphainei, eikós, por exemplo, já estudados no capítulo anterior. Além disso, no mito de Prometeu, o termo prosáidō sugere uma relação entre o mito e o caminho da beleza.

Finalmente, todas as figuras serão vistas em perspectiva com fontes mais antigas, tentando recuar até ao passado mais distante dos mitos escritos: os poemas de Homero e de Hesíodo, ou os fragmentos órficos, no caso de Dioniso. Quando a figura em questão for aludida por Platão, isso será mencionado, como ocorre com o mito de Prometeu e Pandora. Havendo uma menção do mesmo mito em algum dos autores lidos por Plotino, segundo o testemunho de Porfírio, ou mesmo em Porfírio, esta também será citada ${ }^{1}$. Por que buscar as fontes? Em Platão, evidentemente, porque Plotino se considera seu exegeta. Mas no mito de Prometeu, curiosamente, não se verifica nenhuma semelhança com a versão do Protágoras. Nos outros autores, porque sendo a filosofia de Plotino um vasto comentário, não somente das doutrinas, mas também dos mitos do passado, é interessante notar a proximidade, mas também a diferença entre Plotino e o passado helênico.

Retomando as palavras de Cilento (1960, 246): "Uma obra de filosofia é tal, se possui uma nota própria, se é uma palavra nova indictaque prius. Estudá-la, portanto, nas suas fontes, nos predecessores, na matéria da qual é composta, vale a pena, consequentemen-

1. Nesse caso é preciso confiar nas pistas sugeridas em estudos hodiernos, principalmente de Pépin, Cilento e Brisson, uma vez que, face aos limites desta tese, não foi possível elaborar um dossiê completo das ocorrências de cada figura mítica nos textos filosóficos médio-platônicos e em Porfírio, o que seria ideal. 
te, para tentar encontrar onde ela não está”. Assim, é possível perceber que Plotino se porta como filósofo, mesmo quando parece fazer alegoria, ou mística. O que o diferencia da mística nos mistérios, é que seus mitos não fundamentam ritos. $\mathrm{O}$ que o diferencia basicamente dos gramáticos e filólogos, que se ocupavam com alegorias, é que estes seguiam os poemas de Homero tentando desvendar-lhes o sentido oculto. Plotino não segue linearmente nenhum poema, nem mesmo um conjunto de versos, conforme fará Porfírio em seu opúsculo Sobre a Gruta das Ninfas na Odisséia. Plotino, mesmo que conhecesse as fontes épicas e também outras, inventa suas próprias versões dos mitos.

\section{DIONISO DIANTE DO ESPELHO}

Dentre os diversos mitos que nas Enéadas representam algum aspecto da Alma, o de Dioniso simboliza a descida das almas humanas na geraçãó ${ }^{2}$. Quanto às fontes, possivelmente Plotino está aludindo ao mito órfico de Dioniso Zagreu ${ }^{3}$, o qual era interpretado visando ex-

2. Mas este mito permite uma leitura em dois níveis, antropológica e metafísica, podendo também ser interpretado com respeito à alma do mundo como fez, por exemplo, Proclo no seu Comentário ao Timeu, E 164 A, II, que interpretou o mito de Dioniso órfico em perspectiva com o Timeu, 33 b, fazendo do espelho de Dioniso um intermediário entre a unidade inteligível e a multiplicidade inteligível (PÉPIN, 1970, 314).

3. "Em grego, um caçador que captura animais vivos chama-se zagreús. Eruditos gregos da Antiguidade tardia interpretaram o nome como 'grande caçador', por analogia com zátheos (Etymologicum Magnum Gudianum s. v. Zagreús), 'totalmente divino'. Mas a palavra jônia zágre, que significa 'fojo para a captura de 
plicar a divisão entre corpo e alma. Em suma, Dioniso é fruto de um adultério de Zeus e é designado por ele para ser seu sucessor ${ }^{4}$. Hera, enciumada, instiga os Titãs contra Dioniso. Eles atraem o pequeno Dioniso para perto de si com vários brinquedos, como pião, disco, dados e um espelho (Papiro de Gurob, linhas 29-30, in: Fragmentos Orficos, 2007). Dioniso distrai-se olhando sua imagem refletida no espelho e, nesse ínterim, os Titâs cobertos de gesso o despedaçam, cozinham e depois assam as partes e o devoram ${ }^{5}$. Mas o coração do menino é salvo por Atena, que o entrega a Zeus. Ele então reconstitui o filho a partir do coração e fulmina os Titãs com seus raios. Os seres humanos teriam sido criados das cinzas dos Titâs, nas quais havia resíduos do corpo de Dioniso. Donde se explica a dupla natureza humana, em parte titânica, isto é, ctônica, e em parte dionisíaca,

animais vivos', prova que o nome contém a raiz de zoe e zôon, 'vida' e 'vivente'" (KERÉNY, 2002, 72-73). Sobre os mitos órficos em Plotino pode-se consultar CILENTO (1960, 256 ss).

4. Conforme a versão do mito, o adultério é ou com Perséfone, ou Deméter, ou Réia, ou ainda Semele. Sobre o mito órfico do desmembramento de Dioniso, pode-se consultar Fragmentos Or ficos (2007, 17); PÉPIN (1970, 305). Um estudo interessante e bastante detalhado que, entre outras coisas põe em perspectiva os mitos de Dioniso e Prometeu, é DÉTIENNE (1977, cap. 4). Embora haja abundante literatura sobre o mito de Dioniso, dados os limites deste estudo, aqui não se podem explorar detalhes e variantes dela. Porém, ao interessado, pode-se ainda mencionar o estudo clássico de OTTO (1965); KERÉNY (2002) e o outro estudo de DÉTIENNE (1988).

5. Essa estranha preparação, que é o inverso da preparação mais comum das carnes de sacrifício, foi alvo de um comentário atribuído a Aristóteles, e é analisada por Marcel Détienne (1977, cap. 4). 
ou seja, celeste, sendo esta duplicidade ctônica/dionisíaca símbolo da divisão corpo/alma.

Além da exegese órfica, a narrativa do desmembramento de Dioniso recebeu várias interpretaçōes alegóricas, notadamente de autores estóicos e neoplatônicos. A meio caminho entre uns e outros, Plutarco apresenta quatro interpretaçōes diferentes do mito, sendo uma especialmente interessante para alguns exegetas neoplatônicos: comentando o Timeu, $35 \mathrm{a}-\mathrm{b}$, onde a alma do mundo é descrita como sendo composta por uma substância divisível e outra indivisível, Plutarco associa Dioniso esquartejado à alma do mundo presente em todas as partes do universo. Em Plotino, no entanto, o mito de Dioniso ocupa poucas linhas. Nem o esquartejamento, nem o coração salvo e o renascimento do deus, nem mesmo outras figuras míticas envolvidas no episódio são mencionados, exceto Zeus; de fato, o único elemento que se destaca é o espelho.

Plotino, diferentemente de Plutarco, não associa esse mito ao Timeu. O mito de Dioniso concerne às almas dos homens, quando, descendo ao sensível, veem suas imagens refletidas no espelho, o qual parece representar a matéria sensível. As almas entram no corpo, que é o composto de forma e matéria sem, contudo, se separar do inteligível 6 . Eis a passagem:

6. É interessante notar que Plotino explica, logo depois de mencionar Dioniso, que as almas não descem com o Intelecto, o qual permanece no alto. Apenas uma parte das almas desce, ficando outra, "a cabeça" (kára), solidamente fixa no alto do céu (IV, 3 [27] 12, 12). Brisson (in: PLOTIN, n. 257, 229) nota que o termo kára é homérico (Ilíada, IV, 443). Platão no Timeu usa kephalé para expressar a mesma imagem. 
As almas dos homens que veem suas próprias imagens, por assim dizer, no espelho de Dioniso, entraram nas <imagens> lançando-se lá de cima sem, entretanto, separarem-se do seu próprio princípio, que é o Intelecto (IV, 3 [27] 12, 1-4) ${ }^{7}$.

Como se pode ver, o elemento-chave para a compreensão do mito é o espelho no qual se refletem as imagens das almas. Para compreender o sentido da metáfora, é mister recordar um princípio geral da metafísica das Enéadas. Plotino considera que das realidades superiores, que são logicamente anteriores, provêm as realidades inferiores, tal como dos objetos sensíveis vêm suas sombras e seus reflexos nos espelhos e nas superfícies das águas (VI, 4 [22] 10, 12-17) . $^{8}$. Esse princípio aplica-se à Alma, fazendo com que a parte inferior seja imagem da Alma superior, como um reflexo em um espelho (VI, 2 [43] 22, 33-35). Não obstante, como observou Pépin (1970, 44-51), o fato de se refletir em um espelho não confere ao objeto nenhuma realidade suplementar, nem tampouco uma perda de realidade. Com efeito, a imagem refletida é

7. Segue-se Igal para ekeî egénonto ánōthen hormètheîsai: se adentraron en ellas lanzándose desde lo alto. A frase é difícil e resultou nas mais diversas traduções. O significado, conforme se tentará mostrar, corresponde à entrada da alma no corpo, que é uma imagem. Por isso julgou-se adequada a tradução de Igal, e seguiu-se na mesma linha, inserindo <imagens> onde o espanhol diz "en ellas".

8. Sob esse aspecto Plotino parece mostrar-se fiel continuador da hierarquia das imagens que se encontra na conhecida metáfora da linha, na República 509 d ss. 
ato do objeto e desaparece com ele. Analogamente, a alma inferior é ato da Alma, mas em contraste com a metáfora especular, permanece sempre com ela.

Como entender o significado do espelho nessa comparação em que a alma inferior é assimilada à imagem da Alma? Pépin (1970, 317) observa que a matéria é constantemente assimilada a um espelho por Plotino. Porém, Ferwerda $(1965,22)$ considera que nas Enéadas nunca se encontra a palavra "espelho" no sentido metafórico de "matéria": "espelho" aparece sempre em comparações elaboradas, servindo para ilustrar a atividade e o não-ser da matéria, que é algo dificilmente compreensível. Tais comparações encontram-se especialmente no tratado III, 6 [26], sendo que uma das mais nítidas ocorre no capítulo 7 , onde Plotino tenta mostrar que a matéria não é um corpo, mas um tipo de não-ser:

Seu ser, quando aparece, é não-ser, como um brinquedo fugaz; donde o que parece originar-se nela são brincadeiras, imagens em uma imagem sem arte, como em um espelho o que aqui está mostra-se lá. , E, assim parece, ela se preenche, e nada tem, mas tudo aparenta ser (III, 6 [26] 7, 22-27).

Com efeito, as formas inteligíveis não parecem estar realmente "na" matéria, mas sim refletidas nela, tal como aquilo que se reflete no espelho não está no espelho, apenas sua imagem. Isso denota a impassibilidade da matéria, que, não obstante, é ainda mais 
impassível que os espelhos (III, 6 [26] 9, 19). Plotino explica que há uma diferença: o espelho permanece visível, mesmo depois que desaparece a imagem nele refletida, porque ele é, de certo modo, uma forma, ao passo que a matéria, quando não há mais nela o reflexo de uma forma, deixa de ser visível (III, 6 [26] 13, 34-44). Por não ser possível ver a matéria, acredita-se que as coisas sensíveis sejam verdadeiras. $\mathrm{O}$ mesmo não ocorre com as imagens nos espelhos, pois, desaparecidas as imagens, o próprio espelho continua visível, sendo possível diferenciar o espelho da imagem e perceber que a imagem não é uma realidade verdadeira. Deve-se notar, por outro lado, que, sem a matéria, não haveria mundo sensível (III, 6 [26] 14, 1-2).

Todavia, voltando ao mito de Dioniso tal como Plotino o menciona, percebe-se que é uma imagem (eídōlon) de si mesma que a alma vê refletida no espelho. $\mathrm{O}$ que isso significa? Que imagem é essa? Para entender com mais precisão esse ponto, é necessário observar uma sutileza do pensamento plotiniano: a produção do mundo sensível resulta de uma dupla operação: a alma do mundo enforma cada corpo, e as almas individuais são ligadas a eles, com o fito de cuidá-los e conduzilos. Mas isso não significa que haja naturezas psíquicas distintas: a Alma é uma só e idêntica a si mesma, apesar da divisão nos corpos individuais. Portanto, pode-se dizer, com Pradeau (2003, 77-78), que o caráter divisível não é uma característica substancial, mas sim uma aptidão funcional. Não é, portanto, a própria Alma que se encontra no sensível, mas uma imagem da Alma (BLUMENTHAL, 1971, 15). A essa imagem 
da Alma, que desce, Plotino também se refere como parte inferior ${ }^{9}$. É mister não confundir essa imagem da Alma com a alma do mundo, a qual, em sentido estrito, não desce ao sensível. O que enforma a matéria são seus $\log _{\text {goi }}{ }^{10}$. Tais lógoi consistem em imagens da alma do mundo, reflexos que dão existência a tantos quantos forem os corpos sensíveis, sem que, no entanto, ela deixe de possuir unidade (V, 9 [5] 6, 15-24). Os lógoi não somente explicam a formação do sensível, como igualmente justificam sua bondade, pois, graças a eles, o sensível participa do inteligível. Assim, tanto a cosmologia como a teoria da alma plotinianas repousam sobre a tripla distinção entre a matéria indeterminada, os corpos, enformados pelos lógoi, e a Alma que é causa do sensível (PRADEAU, 2003, 73). Ao mesmo tempo, como já se pôde ver no mito genealógico de Eros, os lógoi constituem um elo de ligação entre o inteligível e o sensível. Não obstante, se apenas os lógoi escorrem em direção à matéria, seria possível, então, associar a parte superior da Alma, que fica ligada ao Intelecto, ao coração do pequeno Dioniso, embora Plotino não o

9. O tema em causa é desenvolvido em IV, 8 [6] 8. Essa tese, aliás, "é uma das mais originais e mais importantes do plotinismo" (LAURENT, 1999, 129).

10. Com efeito, ao analisar o tratado IV, 7 [2], Pradeau (2003, 71 ss.) notou que, não utilizando o recurso tradicionalmente adotado no médio-platonismo, do demiurgo que trabalha seu material, Plotino introduz um intermediário entre a Alma e a matéria: os lógoi que, provindo da alma do mundo, enformam a matéria. Esse ponto é complexo, mas a propósito pode-se consultar também o já mencionado artigo de BRISSON (1999). 
mencione, porquanto esta é a única parte do corpo do menino que foi salva do banquete titânico.

Outrossim, as considerações que acabam de ser feitas abrem margem para se aludir a uma outra metáfora, a do brinquedo, porque pode esclarecer, sob certo aspecto, o significado das imagens refletidas no espelho, mas também porque o espelho de Dioniso constava entre brinquedos. É interessante notar que, na passagem supracitada acerca da matéria, Plotino faz uso do procedimento denominado por Ferwerda (1971, p. 194) de "verificação dos termos metafóricos e das imagens": ao substituir uma metáfora por outra, a fim de esclarecer a mesma dificuldade sob outro ângulo, Plotino verifica a primeira. Nesse caso, a primeira metáfora é a do brinquedo fugaz, associada à noção de não-ser. Deste brinquedo originam-se brincadeiras, isto é, imagens em uma imagem. Por fim, a imagem - brinquedo é comparada ao espelho. Inicialmente, é interessante compreender o sentido do termo traduzido por brinquedo, paígnion nas Enéadas, que Ferwerda traduz em holandês por drogbeeld, isto é, imagem enganadora ${ }^{11}$. Embora essa noção possa ser aplicada corretamente a paígnion, parece que ela não revela amplamente o significado do termo para Plotino, porquanto o paígnion designa uma imagem da

11. Ele também explica paígnion como uma espécie de "fata morgana" e de faux-fuyant, que significa inicialmente uma trilha num bosque, ou um desvio por onde a caça escapa, e, por extensão, subterfúgio, pretexto (FERWERDA, 1965, n. 2, 163). A esses sentidos, como se tentará mostrar, é preferível o de brinquedo, tradução literal de paígnion em português. 
realidade que encanta, seduz, e por isso ilude, engana, podendo ter uma conotação pejorativa, mas não necessariamente. Assim, a palavra "brinquedo", donde deriva por extensão "brincadeira", a qual remete à noção de uma situação que imita a realidade, produzindo a sensação de encantamento e divertimento nos participantes, denota mais adequadamente os significados que o termo possui nas Enéadas ${ }^{12}$. Com efeito, o termo paígnion em Plotino que concerne à matéria, definida como um certo não-ser, também se refere ao mundo sensível ou a um determinado aspecto deste, como a beleza, ou a própria vida no sensível. Plotino diz que quem conhece a beleza de lá e a venera, não despreza a beleza daqui, embora reconheça nela um efeito (apotelesmáti) e um jogo de reflexos, uma brincadeira (paígnion) com a beleza de lá (III, 5 [50] 1, 60-62) ${ }^{13}$. Por outro lado, os próprios seres humanos podem tornar-se brinquedos, quando participam da brincadeira que é este mundo. Aqueles que ignoram que são brinquedos em uma brincadeira sofrem. Em III, 2 [47] 15, 47 ss., Plotino diz que, em todas as circunstâncias da vida real, é a sombra da alma que geme e lamenta, desempenhando todos os papéis, neste teatro de múltiplas cenas, isto é, a vida no mundo sensível. A sombra da alma representa o homem que só é capaz de viver uma vida inferior, ignorando que

12. Ademais, as palavras brinquedo e brincadeira remetem à ideia de distração infantil e, nesse sentido, parece ser mais próxima do termo grego, que deriva do verbo paízō e possui na raiz o termo paîs.

13. Ver também a metáfora do brinquedo em IV, 3 [27] 10, 18, referindo-se aos objetos produzidos pela arte, depois da natureza. 
suas lágrimas e suas mais sérias ocupações são como uma brincadeira (paígnion). Ele leva a brincadeira a sério, por desconhecer que é uma brincadeira, sendo ele mesmo um brinquedo. Em oposição a ele, surge a figura do spoudaîos, isto é, o "homem sério", que leva a sério as coisas sérias (III, 2 [47] 15, 53-54) ${ }^{14}$. O homem sério, que corresponde à alma interior, sabe discernir a brincadeira da verdade, porquanto ele possui os critérios do discernimento, que vêm do Intelecto ${ }^{15}$. Plotino menciona Sócrates como exemplo de homem sério, dizendo que nada o impede de brincar com as coisas deste mundo, pois é o Sócrates exterior que brinca, e não o interior. Ademais, continua Plotino, se alguém brinca com estes homens que são eles mesmos paígnia, este alguém vai tornar-se brinquedo também, ao fazer uso do brinquedo que ele tem em si mesmo. Por isso, após brincar, o homem sério deve guardar o brinquedo. O que se pode notar, na metáfora do brinquedo, é que em si ele não é nem bom, nem mau. $\mathrm{O}$ problema está em quem participa da brincadeira. Sendo este alguém capaz de discernir o fascínio do jogo da verdadeira realidade, da qual a brincadeira é imitação, ele não se torna um joguete e ainda é capaz de admirar a beleza de tal representação da realidade. Mas, caso o partícipe se deixe fascinar pela brincadeira, não percebendo ser ela um reflexo da realidade superior, então ele mesmo se torna um mero brinquedo, ou ainda,

14. Sobre o spoudaîos ver o interessante estudo de SCHNIEWIND (2003).

15. O “homem sério" é a alma interior (III, 2 [47] 15, 48). 
uma marionete neste grande theatrum mundi, que é o sensível ${ }^{16}$.

\section{DE DIONISO A PANDORA: A DESCIDA DAS ALMAS}

Mas como se pode entender a liberdade humana, se a descida das almas parece acontecer necessariamente? Qual é o papel da providência na descida das almas? O tema da encarnação das almas, ligado ao da formação do mundo sensível, é tratado nos capítulos 12 a 14 do tratado IV, 3 [27]. Se, no capítulo 12, encontra-se a breve alusão ao mito de Dioniso, o décimo quarto é dedicado ao mito de Prometeu e Pandora. O autor das Enéadas faz Pandora ser modelada por Prometeu, que representa a providência, e Pandora, a vinda da alma ao mundo sensível. Os mitos de Dioniso e de Prometeu e Pandora, de certo modo, se complementam no tratado, versando o primeiro acerca da descida das almas individuais, e o segundo sobre a descida da alma do mundo e a providência. Mas ambas as descidas, na verdade, respondem a um mesmo movimento processional. Assim, antes de analisar o mito de Prometeu e

16. O homem é assimilado a uma marionete em Platão, Leis, X 889 a. O tema do teatro do mundo é de origem estóica (LAURENT, 1999, 126). Porém, Plotino se utiliza da metáfora do teatro no tratado III, 2 [46], Sobre a providência, dizendo que há um autor que distribui os papéis e as réplicas apropriadas a cada ator. Do mesmo modo, nos dramas humanos, a alma é o ator que recebe do poeta do universo o papel a desempenhar. Cabe a ela, como ao ator, interpretar bem ou mal seu papel (III, 2 [47] 17, 28 ss.). 
Pandora, cabe discorrer acerca desse movimento, notando que a processão é necessária, mas que há uma parte de responsabilidade imputada a cada alma, que corresponde ao seu próprio estado de purificação.

Dessarte, no tratado IV, 3 [27] 12, logo após mencionar o mito de Dioniso diante do espelho Plotino, aludindo ao pai do jovem deus, explica:

'Zeus o pai, compadecido'17 da aflição $<$ das almas $>$, torna mortais os laços que as fazem sofrer e lhes concede períodos de repouso livres do corpo, a fim de que elas também possam estar lá onde permanece sempre a alma do mundo, que nunca se volta para as coisas daqui (IV, 3 [27] 12, 8-12).

Plotino está se referindo às almas humanas que descem ao corpo, considerando a morte como uma pausa, na qual as almas podem retornar ao inteligível. É interessante observar que nessa passagem fica explícita a ideia aventada na análise do mito de Dioniso, de que a alma do mundo não desce até ao sensível, permanecendo sempre no inteligível. Plotino segue tentando mostrar que, tanto o retorno, como a descida das almas individuais, está em pleno acordo (symphōnía) com a ordem que reina nesse mundo. As almas, com efeito, não estão separadas umas das outras, mas elas descem estando em contato, produzindo

17. Fórmula homérica, ver Ilíada, XV, 12. Citada também em PLATÃO, Banquete, 191 b 5. 
assim um acordo único com o movimento circular; "como se <cantassem> em uma só voz sem ser permitida dissonância” (IV, 3 [27] 12, 19-24), afirma Plotino. A propósito, ele observa que as palavras "musicalmente" e "harmonicamente" referem-se de maneira enigmática (einigménōs) a esse movimento (IV, 3 [27] 12, 26). Com isso Plotino nota que se trata de boas metáforas para o movimento cósmico. Porque o universo age conforme o inteligível, o movimento cósmico é harmonioso (IV, 3 [27] 12, 27-28), como se o Intelecto fosse um regente a orquestrar a alma do mundo e as almas individuais. Explorando ainda a metáfora, a alma do mundo seria solista nessa sinfonia.

Pois bem, Plotino encerra o capítulo explicando que a Alma superior não desce, mas permanece junto ao Intelecto, iluminando o que se encontra sob ela: ilumina a alma do mundo sempre do mesmo modo, ao passo que ela ilumina cada alma individual de um modo (IV, 3 [27] 12, 32-35) ${ }^{18}$. Esta distinção é importante para introduzir o tema seguinte: cada alma individual possui uma disposição própria. Plotino termina o capítulo sugerindo que também no mundo sensível há um acordo entre corpo e alma, pois cada alma que desce vem a um corpo, pronto para recebê-la, o qual corresponde à sua própria disposição (diathéseōs), sen-

18. Note-se a mudança das metáforas: enquanto aquelas do registro musical explicavam o movimento ordenado de subidas e descidas das almas, em acordo com o movimento do cosmos, a metáfora da iluminação concerne à relação hierárquica entre a parte superior da Alma, que ilumina, e a parte inferior - da qual fazem parte tanto a alma do mundo, como as almas individuais - que é iluminada. 
do a alma transportada a um corpo com o qual ela possui semelhança, seja de um ser humano, seja de outro vivente (IV, 3 [27] 12, 38-39). Significa, portanto, que cada alma que vem a um corpo possui certo nível de perfeição, correspondente a uma disposição moral, a qual determina aonde ela vai encarnar.

Pois a inelutabilidade e a justiça estão assim na natureza, que comanda cada <alma>, em ordem, para se dirigir a cada <corpo $>$ que é imagem gerada do modelo, <segundo a $>$ escolha prévia e a disposição <da alma $>$, e esta <inelutabilidade> é que cada espécie de alma é vizinha daquele <corpo $>$, em direção ao qual a leva a disposição que está nela (IV, 3 [27] 13, 1-5).

Para compreender esse ponto, faz-se mister aludir brevemente à metempsicose, tal como Plotino a concebe, notando que ele se apoia nitidamente em Platão. Embora tal teoria seja mencionada em diversos diálogos (Mênon, Fédon, República, Fedro, Timeu, Leis), basta recorrer ao Fédon e à República para que se obtenha o pano de fundo platônico subjacente à teoria plotiniana. No Fédon 81 e - 82 b, Platão mostra que a reencarnação ocorre de acordo com os hábitos daquele que vai reencarnar; assim, por exemplo, os concupiscentes reencarnam em asno, os justos por hábito, não por conhecerem a verdadeira justiça, reencarnam em espécies tranquilas e gregárias, como as abelhas. Dixsaut (in: PLATON, 1991, nota 156, 355-356) considera que Platão usa metaforicamente a zoologia, para proceder a uma classificação das almas. Como nas fá- 
bulas de Esopo, segue a estudiosa, os animais servem para decifrar o homem e não o contrário: os animais não têm nada de humano, mas o homem, caso não use sua parte divina, isto é, se ele não é filósofo, não passa de uma espécie animal. Na República, 620 a 2-3, Platão mais uma vez parece fazer uma alegoria com a noção de que a alma reencarna em espécies animais, querendo mostrar que as almas seguidamente escolhem sua vida futura em relação às condições da vida anterior. Assim, em ele faz o personagem Er contar que viu Orfeu escolher uma vida de cisne, viu Tamiras, um aedo trácio, escolher a vida de rouxinol e, inversamente, viu cisnes e aves canoras optarem por vidas humanas. Ájax escolheu a vida de um leão, Agamenon a de uma águia e assim por diante, até chegar a vez de Odisseu, que decidiu pela vida de um particular tranquilo. Outros animais passavam para homens e estes para bichos, sendo que os injustos tornavam-se feras selvagens, e os justos, animais domésticos. Ora, esta passagem parece confirmar que Platão enseja mostrar a quem está aqui neste mundo "que seu destino se joga nos seus atos, nas suas palavras e seus pensamentos" (LAURENT, 1999, 120).

Plotino confere à teoria da metempsicose uma conotação ética, na linha de Platão, considerando também que a conduta humana é central para a distribuição das vidas. Ele admite, entretanto, que as almas imortais possam reencarnar em homem, animal ou até mesmo planta, pois provêm de um princípio comum (IV, 7 [2] 14, 1-7). O que justifica esse intercâmbio entre espécies, durante as reencarnações, é a conduta da alma. Se ela se afasta da sua verdadeira natureza e se perde na 
multiplicidade, só lhe resta esperar por um destino infeliz (II, 3 [52] 8, 9-12). Em outros termos, no tratado III, 4 [15], Plotino considera que em cada homem uma parte da alma domina, seja a superior, a sensitiva ou a vegetativa. Quando a alma deixa o corpo, ela se torna aquela parte que, durante a vida, era mais desenvolvida. Por conseguinte, aqueles que desenvolveram a sensitiva, tornam-se animais. Dentre esses, caso a irascibilidade tenha se agregado às sensações, virão como feras selvagens, por exemplo. Plotino segue dando exemplos relativos à zoologia semelhantes aos que se encontram em Platão. Além das reencarnações animais, ele menciona ainda a possibilidade de se tornarem árvores, para aqueles nos quais dominava a faculdade vegetativa, como é o caso dos glutōes (III, 4 [15] 2, 11-30).

Até aqui Plotino parece mostrar que a responsabilidade humana preside o destino das almas. Mas Plotino não considera que as almas desçam aos corpos somente em decorrência de um movimento delas próprias. Quer dizer, ainda que certa alma encarne em um corpo semelhante a ela mesma, isso não é apenas fruto de uma vontade individual, na medida em que é um movimento integrado a uma necessidade cosmológica ${ }^{19}$. No tra-

19. Esse aspecto pode ter origem estóica. Laurent $(1999,126)$ julga que a teoria da metempsicose plotiniana se mostra dividida entre uma visão necessitarista da reencarnação, de origem estóica, segundo a qual tudo está previsto na ordem do mundo, e uma visão de origem platônica, na qual o homem possui a iniciativa da escolha da sua vida. Contra Laurent, tentar-se-á mostrar que não há divisão, não há nem mesmo contradição entre o necessário e o voluntário, porquanto o voluntário é compreendido na necessidade. 
tado IV, 8 [6], que versa exatamente sobre a descida das almas nos corpos, Plotino afirma não haver contradição entre estes termos, o voluntário e a necessidade (tò ekoúsion hè anánkè), pois a necessidade implica o voluntário (IV, 8 [6] 5, 1-3). Ele assegura que a necessidade não é uma obrigação externa às almas que descem, mas é expressão da sua própria natureza, sendo-lhes interior. Em IV, 3 [27] 14, 22 ss., ele vai mais além: há uma lei universal, ou um destino, que é anterior ao mundo. O próprio Intelecto segue esse destino permanecendo onde está, e enviando tanta luz quanto lhe é possível. Conforme essa lei, cada raio de luz é enviado. Esta lei, explica Plotino, não é exterior; ela é dada àqueles que podem fazer uso, nutrindo-os do desejo de ir até onde a lei os leva, por assim dizer. Com essas palavras, Plotino introduz o tema da providência, que será tratado a partir do mito de Prometeu e Pandora.

Mas, antes de ver o mito, é mister compreender que esta lei interior está intimamente associada à vontade. Quer dizer, o Intelecto deseja e precisa produzir algo para além dele, a fim de se perfazer; essa produção é expressão, ao mesmo tempo, da vontade e da necessidade do Intelecto. Assim, a voluntariedade não constitui uma escolha qualquer, mas uma espécie de realização da sua própria identidade. Algo semelhante se aplica à Alma, pois, se ela não descesse, ou melhor, se uma parte ou imagem dela não descesse, a Alma como um todo, não se definiria e nem se distinguiria do inteligível. De fato, se a Alma não tornasse visíveis suas potências, elas teriam existido em vão, pois nunca ter-se-iam tornado ato. Além disso, a Alma jamais 
conheceria as coisas que ela possui, as quais permaneceriam totalmente escondidas, sem existência real (IV, 8 [6] 5, 28-35). Assim, a necessidade de descer ao corpo, em consequência do próprio movimento cósmico, unida à vontade de encarnar, permite à Alma realizar-se enquanto tal, pois no corpo ela conhece suas potencialidades, que se tornam atuais. Lavaud (in: PLOTIN, 2002, 237) sintetizou adequadamente a problemática, assegurando que o corpo não somente manifesta a inteligibilidade da Alma, mas ele é também parte integrante desta inteligibilidade; ele a constitui, pois, sem o corpo, a Alma não poderia ser integralmente compreendida.

\section{O MITO DE PROMETEU E PANDORA}

Explicando a descida das almas ao mundo sensível e o papel da providência, Plotino narra o mito de Prometeu e Pandora em IV, 3 [27], 14. O capítulo inicia aludindo à formação do mundo sensível: "Tão logo isso ocorra, este mundo, que contém muitas luzes e que é iluminado pelas almas, se adorna com novos adornos sobre os precedentes, um provindo de <uma fonte $>\mathrm{e}$ um outro de outra, tanto dos deuses de lá como dos intelectos que lhes dão almas" (IV, 3 [27] 14, 1-4) ${ }^{20}$. A metáfora dos adornos é conhecida, tendo sido mencionada no mito de Eros, por ocasião da descrição do jardim de Zeus. Naquele mito, os adornos pareciam

20. Nessa passagem, Plotino joga com dois sentidos de kósmos, mundo e adorno, o que não foi possível manter na tradução lusófona. 
corresponder aos lógoi que se difundiram do Intelecto para a alma do mundo, através da Alma, representada pelo jardim. Aqui, no entanto, os adornos provêm dos intelectos imanentes às almas e dos deuses inteligíveis, que parecem corresponder às próprias formas no Intelecto (IGAL, in: PLOTINO, 1989, n. 132, 342). Essa primeira parte, dotada de certo lirismo, faz a passagem para o mito de Prometeu e Pandora. Antes de ver o mito propriamente, cabe observar como Plotino o introduz e como o conclui.

O mito é introduzido como um discurso verossímil, que conta algo em termos velados ${ }^{21}$. Ao final do capítulo, Plotino está ciente de que o mito pode ser alvo de múltiplas interpretações, mas ele parece considerar que uma apenas é verdadeira: "Pois bem, interprete-se isto segundo sua opinião, mas <este mito> mostra o que é o presente dado ao mundo e foi recitado de acordo com o que se disse anteriormente" (IV, 3 [27] 14, 17-19). É interessante notar o termo prosáidei, designando a ação de narrar o mito. Este termo, em grego, também significa cantar. $\mathrm{O}$ mito, porque é capaz de mostrar (emphaínei), foi até este ponto do estudo designado como um discurso por imagens, mas surge agora como um discurso recitado de acordo com o dito anteriormente. Isto é, com o discurso cerrado dos capítulos anteriores, onde nem mesmo os interlocutores anônimos irromperam. Essa passagem é singular por ser a única, dentre as aqui estudadas, em que

21. "Como é verossímil o que diz o mito em termos velados" (IV, $3[27] 14,5)$. 
o mito é cantado, recitado, ou seja, em que ele parece ser posto no nível da poesia. A poesia, que se identifica com a música, constitui um meio para se atingir a unidade através do caminho da beleza. E este é um caminho disponível para o filósofo, pari passu com o da dialética; afinal, é sabido que no inteligível todas as formas se fundem: beleza e sabedoria lá são o mesmo. Todavia, é preciso cuidar em não considerar subitamente Plotino poeta ${ }^{22}$. Pois, como o próprio Cilento adverte, em "Mito e poesia nelle Enneadi de Plotino", Plotino é filósofo, embora dentre suas fontes constem mitos e poemas, vindos de fontes épicas, órficas, trágicas e filosóficas. Se Plotino pode cantar o mito, e se pode tentar mostrar o invisível através do mito, é sempre em vista do esforço em falar sobre o inexprimível, aquilo que, ao final das contas, desemboca no silêncio da contemplação. Após este breve excurso, é possível, finalmente, analisar o mito de Prometeu e Pandora. Na primeira parte do mito, Plotino trata da formação de Pandora:

Como é verossímil o que diz o mito em termos velados, quando Prometeu plasmou a mulher, os outros deuses também a adornaram: amassou terra e água, infundiu-lhe voz humana, deu-lhe aparência semelhante às deusas; Afrodite e as Graças deram cada uma um presente. $\mathrm{E}$ dos presentes que todos

22. Quiçá movido pelo entusiasmo, Henry tenha usado a expressão "Plotin poète", no debate suscitado, por ocasião da apresentação de Cilento, nos Entretiens de la Fondation Hardt, cujo tema eram as "fontes de Plotino" (1960, 315). 
lhe deram nomearam-na presente (dốrou); pois todos <os deuses $>$ presentearam a esta $<$ mulher $>$ plasmada por um previdente (promètheias - IV, 3 [27] 14, 1-11).

Como o próprio Plotino diz, ao final do capítulo (IV, 3 [27] 13, 17-19), o mito trata do presente dado ao mundo. Tal presente parece ser Pandora, cujo nome significa, ao mesmo tempo, "presente" e "todos" os presenteadores. $\mathrm{O}$ recurso à etimologia é de uso comum nas interpretaçóes alegóricas, como se sabe. Nesse caso, a etimologia do nome de Pandora parece aludir a Os Trabalhos e os Dias, 80: "E a esta mulher chamou Pandora, porque todos os que têm olímpia morada deram-lhe um dom" (HESÍODO, Os Trabalhos e os Dias, 80). Como a figura de Pandora, para Plotino, parece aludir à vinda da alma ao mundo sensível, ele faz com que seu nome signifique tanto o presente que representa para o mundo a vinda da alma, quanto os presenteadores, que adornaram a alma na ocasião da formação do mundo. Quem são os presenteadores? Plotino diz, seguindo nisso Hesíodo, que todos os deuses presentearam a essa mulher. Mas ele cita em especial as Graças e Afrodite ${ }^{23}$. Ora, já foi visto que essas figuras representam a beleza, mas também que Afrodite simboliza a Alma em todos os seus níveis. Aqui ela parece aludir à Alma superior, que fornece

23. Enquanto Hesíodo menciona, em Os Trabalhos e os Dias, 71-77, Atena, as Graças, Persuasão, as Horas e Hermes. Na Teogonia 572 ss., ela é adornada por Atena e pelo artífice que a fabrica, Hefesto. 
lógoi para a parte que desce. Portanto, todos os deuses devem aludir aos lógoi inteligíveis, que finalmente a alma do mundo distribui para o sensível. Ao final da passagem, Plotino declara que ela foi plasmada por um ser previdente, jogando de novo com a etimologia, pois o nome Prometeu (previdente) é associado a promètheía (previsão). O titã representa, portanto, a providência, a qual corresponde às leis que regem o mundo e são dadas a este universo, através dos lógoi (IV, 3 [27] 15, 15-23). Brisson (1999, 104) resumiu assim: "A providência pode ser compreendida como o conjunto de lógoi considerado, não na sua função de produção, mas na de garantidores da permanência dessa organização". Com efeito, tais leis se aplicam, não somente aos processos naturais, mas também à escolha das almas individuais, quando reencarnam. Portanto, Prometeu, ao produzir Pandora, pode tanto representar a passagem dos lógoi da parte superior da Alma para a alma do mundo, como, igualmente, para as almas individuais.

Resta a enigmática passagem inicial que descreve a produção de Pandora. Difícil saber exatamente a que Plotino alude, talvez terra e água sejam metáforas para forma e matéria, talvez a voz humana e a aparência de deusa também expressem o que é material e o que é imaterial, divino. Na produção de Pandora, em $O s$ Trabalhos e os Dias ${ }^{24}$, a voz humana da qual essa mu-

24. "Disse assim e gargalhou o pai dos homens e dos deuses;/ Ordenou então ao ínclito Hefesto muito velozmente/ Terra à água misturar e aí pôr humana voz e/ Força, e assemelhar de rosto às deusas imortais" (HESÍODO, Os Trabalhos e os Dias, 59-62). 
lher é dotada parece significar que ela se torna viva, e não somente que pode falar (LECREC, in: HÉSIODE, 1999, 136) ${ }^{25}$. É mister notar que, embora seja possível tecer algumas aproximaçôes entre o mito de Prometeu, nas Enéadas, e as narrativas hesiódicas, Plotino aporta variações consideráveis. Uma delas consiste em substituir Hefesto, que produz Pandora seguindo ordens de Zeus, por Prometeu. Hefesto, com efeito, é citado nas Enéadas em um tratado, cujo tema é justamente a providência. Em III, 2 [47] 14, Plotino está tentando explicar que a ordenação do mundo, mesmo não sendo planejada, é mais perfeita do que se o fora, porquanto é necessária. $\mathrm{O}$ mundo é feito de partes coordenadas ao conjunto, de tal modo que mesmo no homem surja a percepção de uma espécie de escultura grandiosa e bela (PLATÃO, Timeu, 37 c 7; 92 c 7-9), enformada por uma alma, lavrada pela arte de Hefesto (III, 2 [47] 14, 25-30) ${ }^{26}$. O deus artesão, portanto, parece significar por alusão a alma que enforma. Nesse caso, o simbolismo de Hefesto está próximo ao de Prometeu, sendo que talvez Plotino tenha trocado o produtor de Pandora, seguindo alguma outra versão do mito, a exemplo daquela que o autor do $A d$ Gau-

25. Além disso, a expressão "uma voz humana e a força" retoma uma fórmula homérica (Ilíada, 419-420), que se aplica aos serventes de Hefesto, indicando ser Pandora fruto de uma fabricação artesanal.

26. Cilento (1960, p. 258) considera que a figura de Hefesto aludida por Plotino pertence ao panteão órfico, no qual ele era o produtor e demiurgo deste mundo visível. 
rum viu representada no teatro ${ }^{27}$. Uma outra diferença em relação a Hesíodo concerne à segunda parte do mito. Enquanto o poeta entende que Epimeteu recebe Pandora presenteada por Zeus e com ela contrai matrimônio, para Plotino, o gêmeo recusa o presente enviado pelo próprio irmão, Prometeu.

E Epimeteu, recusando este presente $<\mathrm{de}$ Prometeu $>$, o que pode significar senão que é muito melhor escolher o $<$ presente $>$ do inteligível (V, 3 [27] 14, 11-13)

Considerando Prometeu símbolo da providência e Pandora símbolo da parte da alma que desce ao sensível, resta compreender a frase que introduz a figura de Epimeteu, que nada parece guardar do gêmeo antitético de Prometeu ${ }^{28}$. Provavelmente Epimeteu representa a parte superior da alma do mundo, e de todas as al-

27. No Ad Gaurum (48, 10-14 Kalbfleisch = XI, 1 Festugière), texto atribuído a Porfírio, é mencionado o mito de Prometeu, ligado à apresentação cênica: "Como vi no teatro, aqueles que interpretam Prometeu são forçados a fazer entrar a alma no corpo enquanto o homem, recentemente produzido, está estendido no solo". Talvez Plotino esteja se referindo a alguma representação teatral desse tipo. Outrossim, cabe notar que, segundo o autor de Ad Gaurum, este mito representa a entrada da alma humana no corpo, logo após o parto. Quanto à encenação teatral aludida pelo autor, possivelmente trata-se de uma comédia. Algumas referências, concernentes à fabricação do homem por Prometeu, a partir da argila são: Filémon, frag. 89 Kock; Menandro, frag. 535 Kock; Aristófanes, v. 836.

28. Enquanto Prometeu é o previdente, prudente, Epimeteu é o torpe, que só pensa depois de agir. Ver Hesíodo, Teogonia, 511; Platão, Protágoras, 321 b. 
mas, que ficam no inteligível ${ }^{29}$. Ele escolher o presente do inteligível nada mais é do que não descer, não se misturar ao corpo. Prometeu, por sua vez, está aprisionado ao sensível, do qual pode libertar-se:

Mas aquele que a fabricou está aprisionado, porque de certo modo está ligado ao que fez vir a ser, e porque semelhante laço é externo; e sua liberação por Héracles significa ter ele a potência que permite liberar-se (V, 3 [27] 14, 13-17)

Essa parte final do mito alude à história de Prometeu acorrentado, na Teogonia. Zeus puniu Prometeu acorrentando-o ao cimo do Cáucaso, porque ele havia roubado o fogo para dá-lo aos homens. Diariamente uma águia vinha devorar-lhe o fígado, até que uma flecha certeira de Héracles matou a ave, fazendo com que o castigo perdesse o sentido. Segundo a interpretação alegórica de Plotino, a providência (Prometeu) fica, de certo modo, ligada àquilo que produziu, na medida em que ela mantém a ordem no mundo. Mas esse laço é externo, pois, de fato, a parte superior da Alma não desce, donde a providência tem o poder de se liberar. Em alusão à Odisséia XI, 601-604, a figura de Héra-

29. Epimeteu representa a parte superior da alma do mundo, conforme a sugestão de Igal (in: PLOTINO, 1989, n. 136, 343). Brisson (in: PLOTIN, n. 312, 232) considera que Epimeteu é uma figura difícil de interpretar. 
cles é mencionada em várias passagens das Enéadas ${ }^{30}$. No referido passo da Odisséia, uma das sombras que Odisseu encontra no Hades é a de Héracles, mas Homero precisa que não passa de um reflexo, pois o verdadeiro Héracles está entre os deuses. Plotino faz dessa passagem uma expressão da sua teoria da dualidade das almas. Os lógoi e a vida que a alma do mundo confere ao corpo do mundo são o eídōlon do seu lógos e da sua própria vida (V, 3 [27] 10, 38-40) O mesmo ocorre com as almas humanas, como mostra o mito de Dioniso: olhando do alto do inteligível, elas veem nos seus corpos seus próprios eídōla, como no espelho do jovem deus. É possível então aproximar essas passagens ao mito do reflexo de Héracles: sua sombra no Hades representa o reflexo das almas no sensível, enquanto o verdadeiro Héracles permanece junto aos deuses, representando a parte superior da Alma, que não desce. Pépin $(1971,177)$ nota que Héracles figurar a liberação da alma providente não é estranho à interpretação que Plotino faz da dupla alma do herói, na qual também está em questão a liberação da alma superior ${ }^{31}$.

\section{VERSÕES DO MITO DE PROMETEU ANTES DE PLOTINO}

Seria longo, e ultrapassaria muito o escopo deste estudo, elaborar um dossiê que esgotasse as versóes do

30. I, 1 [53] 12 ; IV, 3 [27] 27, 7-14; 29, 3; VI, 4 [22] 16. Sobre Héraclès ver PÉPIN (1971, 167- 192).

31. Ele ainda observa que esse significado de Héracles será seguidamente retomado no neoplatonismo posterior (PÉPIN, 1971, 177). 
mito de Prometeu e Pandora anteriores a Plotino, para buscar as suas possíveis fontes. Mas algumas podem ser aludidas: os poemas de Hesíodo, o Protágoras de Platão, e, finalmente, o fragmento 14 de Numênio. Essas três versões, tão nitidamente diversas entre si, mostram que a figura de Prometeu foi por inteiro reinterpretada. Mas, por outro lado, há um traço comum em todas elas: Prometeu é um distribuidor, e este traço Plotino mantém. Da leitura que acaba de ser feita do mito, percebe-se que Plotino mistura elementos do mito de Prometeu e Pandora (Os Trabalhos e os Dias, 60-89) com o de Prometeu acorrentado (Teogonia, 521-528). Remodelar mitos tradicionais ocorre com frequência nas Enéadas, e, no caso deste mito, Pépin $(1955,17)$ considera as modificações tão significativas que pouco se reconhece o mito hesiódico. Mas, afora esses, é fortemente provável que Plotino - ou Porfírio, ou ainda alguns de seus ouvintes, se considerada a hipótese de os tratados serem transcrições de situações das aulas - tivessem em mente versōes conhecidas desse mito à época.

Começando por Hesíodo, o mito de Prometeu trata, de certo modo, da criação do homem, que, a bem da verdade, é fruto da separação entre homens e deuses. Vernant $(2002,315$ ss.) considera que tal separação implica um status novo à raça humana, sendo marcada pela distribuição dos alimentos, da qual é encarregado o titã, que tem com isso a ocasião de enganar os deuses em proveito dos homens. Depois, ele rouba o fogo que cozinha para dá-lo aos homens, garantindo, assim, que não morram de fome. Em contrapartida, Zeus envia Pandora, a primeira mulher, para viver entre os ho- 
mens. Então os homens conhecem o nascimento pela geração - antes eles nasciam diretamente da terra - e também a velhice e a morte. Pandora, que em Hesíodo foi feita por Hefesto, a mando de Zeus, aparece por vezes como obra de Prometeu ou de seu gêmeo antitético, Epimeteu. Em qualquer dos casos, ela é fruto do trabalho de um artífice, tendo sido formada de terra. O resultado é um ser composto, cuja beleza aparente, copiada da beleza divina (HESÍODO, Os Trabalhos e os Dias, 62-63), contrasta com a maldade interna, expressa na capacidade de mentir e enganar (HESÍODO, Os Trabalhos e os Dias, 78).

A figura de Prometeu foi posteriormente personagem central de uma tragédia de Ésquilo, Prometeu acorrentado, 228 ss, na qual o titã é o único a pensar no homem, opondo-se, assim, a Zeus, quando este estabelece os diversos privilégios entre os deuses e fixa os níveis de seu império. Platão, que devia ter pelo menos 34 anos, na ocasiāo em que Ésquilo redigiu a tragédia, também narrou um mito de Prometeu no seu Protágoras, segundo o qual ele foi encarregado, juntamente com Epimeteu, de distribuir entre todos os seres as qualidades de modo conveniente (PLATÃO, Protágoras, $230 \mathrm{~d}$ ss.). Epimeteu distribui tudo para os animais, não restando nada para o homem. Por isso Prometeu rouba a técnica do fogo a Hefesto e as outras técnicas a Atena. Ele distribui as técnicas aos homens, umas para uns e outras para outros, garantindo ao homem o domínio delas (PLATÃO, Protágoras, 321 d). Mas, ainda que possuíssem o domínio técnico, os homens viviam dispersos e morriam vítimas de feras selvagens. 
Por isso Zeus ordenou a Hermes que levasse aos homens respeito e justiça, que deveriam ser distribuídos a todos os homens, os quais passaram a viver em cidades (PLATÃO, Protágoras, 322 d). Percebe-se claramente que se trata de um mito capaz de justificar a democracia ateniense. Contado pelo sofista Protágoras, parece não expressar o pensamento de Platão, o qual foi um mordaz opositor da democracia, como é consabido.

Numênio de Apaméia parece interpretar o mito de Prometeu, no Protágoras, de modo bastante peculiar $($ NUMÊNIO, Frag. 14 des Places = EUSÉBIO, Preparação Evangélica, XI, 18, 15-19). Versando sobre como a segunda causa provém da primeira, ele se serve da metáfora do presente: os divinos presentes lá de cima chegam aqui embaixo, sem lesar em nada o presenteador. Tal tesouro consiste na bela ciência (epistémē hē kalế), da qual o donatário se beneficia, sem o presenteador ser frustrado. Numênio então se serve de uma nova metáfora, a da lâmpada que ilumina outra lâmpada, sem perder a luminosidade. É que a mecha da segunda lâmpada apenas se alimenta do fogo da primeira ${ }^{32}$. O mesmo ocorre com o tesouro da ciência, que permanece com o doador, pertencendo igualmente a quem a recebe. A substância que possui a ciência, explica então Numênio, é idêntica no intelecto (noûs), que a fornece, e em nós, que a recebemos. "Eis por que Platão também diz que a sabedoria veio

32. A imagem da lâmpada, que comunica seu fogo sem empobrecer, assim como as da luz do sol e do fogo transmitido sem diminuição, parecem remontar a Posidônio (É. des PLACES, in: NUMENIUS, n. 4, 109). 
aos homens por Prometeu ao mesmo tempo que o fogo mais iluminador", diz ele, ao final do fragmento, em uma alusão ao mito do Protágoras. Esse fragmento de Numênio versa sobre o princípio da não diminuição do doador, o qual é fundamental para Plotino, que, como Numênio, o ilustra com a comunicação do conhecimento (IV, 9 [8] 5, 4-9; III, 9 [13] 2) ${ }^{33}$.

As diferenças entre a versão plotiniana e a platônica do mito são tantas que seria relativamente fácil supor que Plotino não estivesse pensando no Protágoras quando aludiu ao mito em causa. Mas, considerando a interpretação de Numênio, pode-se aventar que houvesse de fato outras tantas exegeses de matiz platônica em voga, à época, passíveis de terem chegado ao conhecimento de Plotino. Isso sem mencionar as exegeses gnósticas, que faziam de Pandora uma espécie de Jesus (CILENTO, 1960, 291). Por certo, há outras versões do mito de Prometeu e Pandora que poderiam ser do conhecimento de Plotino, ficando insolúvel a questão das fontes de que ele se serviu. Quanto à encenação que o autor de Ad Gaurum menciona, pode-se supor que ela fosse conhecida de Plotino, na condição de considerar Porfírio o autor deste tratado. Ora, a Enéada IV, 3 [27] foi redigida durante o período em que Porfírio frequentou as aulas de Plotino (PORFÍRIO, Vida de Plotino, 5, 20). $\mathrm{O}$ próprio Porfírio conta que, por três dias, interrogou o mestre acerca do modo como a alma entra no

33. Ver também de Numênio o Frag. 23 des Places. Sobre o assunto, consultar DODDS $(1960,23)$. 
corpo, o que gerou pródigas discussões (PORFÍRIO, Vida de Plotino, 13, 10). Quiçá, no decorrer delas, Porfírio tivesse mencionado o que viu no teatro, incitando Plotino a dar um sentido à narrativa, capaz de mostrar aos seus discípulos o que ele tentava explicar. Também pode ser que esse sentido tenha sido discutido. Isso explicaria a observação de Plotino de que esse mito pode ter muitas interpretaçōes. E, ainda, poderia justificar o termo prosáidei. Enfim, Plotino talvez não tivesse, como diz Cilento $(1945,291)$, "nenhum escrúpulo em acomodar os mitos ao seu intento ou em tratá-los com certa negligência”. Mas, se é impossível identificar, com certeza, a fonte, o debate em torno das versóes anteriores permite observar que, guiado pelos complexos caminhos da exegese, e talvez sem tencionar, Plotino também inventou seus mitos.

\section{UMA FIGURA ANÔNIMA}

Diante do que foi dito, resta uma pergunta: como justificar o mal? Ou o feio? Enfim, como explicar tudo o que é torpe e estranho à perfeição do inteligível? Por um lado, Plotino considera que, se houvesse apenas a alma do mundo, não haveria mal moral, apenas mal residual ou negativo, na medida em que não resultaria de uma intenção, mas sim do limite imposto pela matéria à enformação (BRISSON, 1999, 106). No entanto, por outro lado, Plotino considera o mal como resultado da impossibilidade de se integrar à providência (III, 3 [48] 5, 33-40). Em outros termos, as almas individuais podem agir de modo a se distanciar da pro- 
vidência e, inclusive, de se opor a ela. É o que ocorre quando a alma não é capaz de reconhecer sua origem inteligível, abismando-se nas profundezas do sensível. Este é o tema de um mito anônimo, nas Enéadas. Fruto de uma longa história de interpretações, no século XX, este mito foi associado ao de Narciso por Pierre Hadot (1976), e vários outros após ele. Todavia, há um artigo de Aubenque (2005) que sugere associar a figura anônima a Hilas, o amigo de Héracles, que foi raptado pelas Ninfas quando buscava água em uma cascata, sendo aprisionado nas profundezas lacustres. Mas se o mito é anônimo em Plotino, o mais adequado seria precisamente não tentar nomeá-lo? Respeitando o texto plotiniano, optou-se aqui pelo anonimato da figura. Uma hipótese fundamenta tal decisão: o anonimato da figura tem um significado filosófico preciso. Abismado nas profundezas materiais, o personagem perde sua identidade humana. Sem identidade, como ele poderia ter um nome?

Dito isso, pode-se passar agora à análise desse enigmático mito. Os principais temas do mito anônimo são a tentativa de pegar a beleza refletida nas águas, movido pela paixão, e o fato de o personagem ignorar que se trata do seu próprio reflexo. Isso transposto para a metafísica das Enéadas permite a Plotino explicar que o corpo e o mundo sensível são reflexos da realidade superior. Com efeito, há apenas duas mençôes à figura anônima nas Enéadas. Trata-se de alusões rápidas, as quais se encontram em tratados que versam sobre a beleza. Plotino, através desse mito, tenta mostrar que a paixão pela beleza refletida na matéria conduz a alma 
humana ao abismo de sombras, onde nada é real, onde não há possibilidade de conhecimento, nem pode haver beleza. O conhecimento, para Plotino, está associado à metáfora da visão, donde resulta que a cegueira seja associada à falta de conhecimento ou, em outros termos, à ignorância que se ignora. Outrossim, Vernant (1989, 166) observou que o mito também traduz outro problema: o espelho das águas, no qual o personagem se vê refletido como outro, traduz o paradoxo humano do impulso erótico que visa a nos unir a nós mesmos, a nos reencontrar em nossa integridade, mas que só pode ser atingido através de um desvio pelo outro. Assim, tentar-se-á mostrar como Plotino ilustra tais problemas com esse mito. A primeira e mais importante alusão ao mito, nas Enéadas, é a seguinte:

Pois, se alguém as persegue querendo apreendê-las como algo verdadeiro, será como aquele que quis apreender sua bela imagem fluente sobre a água, como certo mito, em algum lugar, me parece, diz alusivamente (ainittetai), que desapareceu (aphanés) abismando-se no rio; da mesma maneira, aquele que se aferra à beleza dos corpos e não a abandona, abisma-se, não com o corpo, mas com a alma, cai na obscuridade, nas profundezas funestas para o intelecto onde, permanecendo cego no Hades, reunir-se-á por toda parte com as sombras (I, 6 [1], 8, 9-16). 
A outra, bastante breve, diz: "é como se alguém contemplasse sua própria imagem e tentasse atingi-la sem saber de onde ela vem" (V, 8 [31] 2, 32-37). O ponto de partida desse mito, na economia das Enéadas, é a ignorância do personagem com respeito à diferença ontológica existente entre uma imagem, a beleza do corpo, e seu paradigma, a forma da beleza. O mito, portanto, é a narrativa de um fracasso que tem por consequência a queda da alma. Mas, se o protagonista do mito não é capaz de distinguir a imagem do paradigma, é porque ele não consegue sequer voltar-se para seu interior, ou seja, sua alma contenta-se com a visão de uma projeção do seu exterior, isto é, a imagem refletida do seu corpo. Com efeito, a beleza sensível não passa de um reflexo projetado no exterior, isto é, no corpo. A verdadeira beleza não é a que reside no corpo, mas nas almas ${ }^{34}$. O personagem fica preso ao reflexo de um reflexo, pois não consegue perceber a diferença entre o reflexo de seu corpo e seu próprio corpo. Ou seja, ele ignora de onde provém o reflexo. Em outras palavras, se ele toma por realidade substancial o reflexo, ele ignora a relação entre o reflexo e si próprio $^{35}$. Para Plotino, por desconhecer o próprio

34. "Além disso, tanto a beleza nos estudos como a beleza nos hábitos, ou ainda, em geral, a beleza nas almas, revela que isto que é seguido é outro e <que> a beleza não está na grandeza. E certamente, na verdade, há mais beleza quando tu vês a sabedoria em alguém e ficas admirado não olhando para o rosto - este poderia ser na verdade feio - mas deixando de lado todo o aspecto exterior, tu segues a sua beleza interior" (V, 8 [31] 2, 35-41 - trad. Soares).

35. Segundo Hadot (1976, 244), esta é a dimensão psicológica muito mais profunda do pensamento de Plotino em relação a uma 
processo de gênese do mundo, por desconhecer que o próprio corpo é um reflexo da alma na matéria (III, $6[26] 7,25 ; 14,1-2)$, é que alguém, como o anônimo, busca insensatamente o reflexo do corpo ao ponto de desaparecer no fundo das águas.

Desconhecer, para Plotino, tem relação com o nãover, assim como ver remete a conhecer, no vocabulário das Enéadas, conforme já foi visto ${ }^{36}$. No mito em causa, Plotino associa a ignorância a dois aspectos da nãovisão: a invisibilidade e a cegueira. De um lado, o anônimo, ao tentar pegar seu reflexo na água, desaparece, ou ainda, se torna invisível (aphanés). De outro lado, o homem que, conforme o exemplo daquela figura mítica, se mantém apegado às belezas dos corpos, permanece cego (typhlós) nas profundezas do Hades, em meio às sombras. Em um caso, ele não pode ser visto, pois desapareceu. No outro, ele não pode ver. Parece que já está desaparecido, sendo a cegueira a condição de quem se abismou nas profundezas do Hades, ao tentar pegar o reflexo. As duas metáforas, a do desaparecimento ou invisibilidade, e a da cegueira, aludem à condição daquele que está preso à matéria. Com efeito, Plotino, ao explicar em que sentido a matéria

doutrina platônica bastante banal, "a realidade visível é apenas reflexo do mundo das Ideias”. Poder-se-ia pensar, que ela é ilustrada por esta evocação do mito em tese.

36. Recordando o que já foi estudado, a alma é capaz de ver as belezas mais elevadas: "Quanto às belezas ulteriores, que já não cabe à sensação ver, a alma, sem órgãos, as vê e as proclama: devemos contemplá-las, elevando-nos, após deixar que a sensação permaneça aqui em baixo" (I, 6 [1] 4, 1-5 - trad. Baracat Jr.). 
permanece impassível à forma, a compara a um espe1 ho ${ }^{37}$. Mas, enquanto o espelho pode ser visto, pois ele próprio é um corpo com uma certa forma, a matéria, que não tem forma, não tem nada que possa ser visto (III, 6 [26] 13, 38-40). De fato, nem mesmo metaforicamente a matéria pode ser vista, como ocorre com a Alma, o Intelecto e o Um, que metaforicamente são vistos cada qual pelos olhos do nível imediatamente seguinte, conforme mostra o mito de Eros. Isso porque a matéria é de uma natureza totalmente distinta. Ela é totalmente invisível, embora possibilite à forma tornar-se visível no mundo sensível. Quanto à cegueira, há uma passagem bastante interessante, situada em um contexto de ataque aos gnósticos, na qual typhlós se opõe à razão, designando um homem que não possui nem sensação, nem intelecto (II, 9 [33] 16, 37) ${ }^{38}$.

37. "Mas ela <a matéria $>$ deve permanecer, quando as formas entram, e deve ser impassível, quando elas saem, para que haja sempre algo que entre nela e também saia. Então, o que entra, entra como uma imagem e como não-verdadeiro em algo não-verdadeiro. Então, entra verdadeiramente? E como o poderia aquilo a que de modo algum é lícito participar da verdade por ser a falsidade? Então, falsamente entra no falso? É como se alguém visse entrar em um espelho as imagens dos objetos que se refletem e enquanto eles se refletem. Pois, se retiras daqui os entes, em momento algum apareceria nenhuma das coisas que agora são vistas nos sensíveis" (III, 6 [26] 13, 30-37 - trad. Baracat Jr.). A questão do espelho levou Hadot (1976, 247 ss.) a tratar do mito de Narciso em perspectiva com o mito do espelho de Dioniso. Vernant (1989, 165 ss.) também tratou os dois mitos em perspectiva, comparando o espelho de Dioniso com o das águas de Narciso.

38. Há uma expressão semelhante em III, 2 [47] 1, 3: o que não é razoável é próprio de um homem desprovido de intelecto e de sensação. 
Portanto, cego pode ser entendido como desarrazoado, insensato, mas também insensível, já que não possui nem mesmo sensação.

Eclipsada nas sombras do Hades, a alma torna-se cega. Há um conjunto significativo de ocorrências do termo Hades nas Enéadas; de fato, é o lugar mítico mais mencionado por Plotino. Além dele, encontramse o Tártaro e o rio do Lete ${ }^{39}$. Plotino parece mencionar o Hades preferentemente em passagens que acentuam o destino das almas impuras, como as referidas pelo mito do anônimo. As almas que não são puras, ou seja, as que não têm virtudes, permanecerão em um lamaçal no Hades, receberão castigos maiores do que na vida, assegura Plotino, em diferentes tratados ${ }^{40}$. Porém, existe a possibilidade de eleger outro tipo de vida e escapar a tais suplícios. Além disso, Plotino serve-se de um jogo etimológico do Crátilo 403a, entre Háidou e aidề para associar o Hades ao invisível

39. Para as ocorrências de Hades, Tártaro e Letes, ver o catálogo simplificado das figuras míticas, ao final do livro.

40. Sobre a tradição do tema da lama, Ferwerda (1965, 103-104) nota que há uma corrente derivada do orfismo, segundo a qual no Hades os não-iniciados se rebolcarão na lama para expiar. Essa ideia parece encontrar-se pela primeira vez em Platão, Fédon, 69c. Outra corrente deriva da sabedoria popular e é ilustrada por Heráclito, que afirma: o homem médio alegra-se com a ignorância como os porcos rolando na lama (Fr. B 13, DIELS-KRANZ, I, 154). Plotino parece distanciar-se de Platão, porquanto a metáfora da lama acentua a sujeira completa da alma devido ao contato com o corpo, mantendo-se mais próxima à da sabedoria popular de seu tempo. Para Platão, a imagem da lama concerne à ignorância na qual a alma está mergulhada, quando seu olho está obscurecido. 
(VI, 4 [22]) 16, 37-38) ${ }^{41}$. Invisível como a matéria, finalmente o Hades representa o mal, para onde caem as almas viciosas, em oposição ao Bem transcendente, que acolhe as almas virtuosas ${ }^{42}$.

É importante ainda comentar brevemente a metáfora da água, associada ao esquecimento, à cegueira e à fluidez do corpo. De fato, o protagonista sem nome inicialmente não parece cego, pois ele consegue ver a beleza dos corpos refletida no espelho das águas. No entanto, ele não consegue ver nada além do reflexo, afinal deseja o reflexo como se fosse verdadeiro. Amar o reflexo é viver um amor sem memória. $\mathrm{O}$ amor sem memória da origem é exatamente este que considera o amor pelos corpos como verdadeiro amor, e a beleza dos corpos

41. De fato, há dois diálogos platônicos onde o Hades é associado ao invisível, o Crátilo e o Fédon 81c.

42. "Pois, se a alma tomba totalmente no vício total, já não tem vício, mas transformou-se em uma outra natureza diferente pior; pois ainda é humano o vício que está misturado a algo contrário. Morre, então, como a alma morreria, e a morte, para ela, quando ainda imersa no corpo, é afundar-se na matéria e preencher-se dela e, após sair do corpo, aí jazer, até que corra para cima e de algum modo afaste seu olhar da lama: é esse o significado de 'tendo ido ao Hades, lá dormir”" (I, 8 [51] 13, 18-26 - trad. Baracat Jr.). A expressão 'tendo ido ao Hades lá dormir' é uma alusão a Platão, República, 534 c 7 - d 1). "A descrição da descida da alma ao Hades serve para ilustrar essa distinção entre o vício e o mal em si (...). A descida da alma a partir do vício parcial em direção ao vício total é função de um eixo cuja direção é estabelecida por outra coisa que não o vício: a matéria. Os graus de decadência da alma pressupóem assim um mal absoluto que se distingue deles" (O’MEARA, in: PLOTIN, 153). 
como a verdadeira beleza (III, 5 [50] 1, 40; 59-60) ${ }^{43}$. É preciso observar que não é o reflexo, a sombra ou o corpo que aprisionam o homem, mas sua incapacidade de lembrar, de ver para além do corpo. Vem a propósito aludir ao rio do Lete, associado ao esquecimento já em Platão (República, X, 621 c 1-2) ${ }^{44}$. Plotino efetivamente menciona esse rio no tratado IV, 3 [27], exatamente em uma parte cujo assunto é a memória. Ele afirma que a memória pertence à alma, que é estável. Por conseguinte, o corpo é obstáculo à memória e causa do esquecimento devido à sua fluidez e movimento. "Eis por que o rio do Lete deve ser interpretado (hyponooîto) nesse sentido" (IV, 3 [27], 26, 54-55). A menção ao rio do Lete é interessante porque permite compreender que, para Plotino, a natureza fluida da água pode aludir ao corpo em sua parte material, em oposição à estabilidade da alma e do inteligível de modo geral. Evidentemente, como demonstra Ferwerda (1965, 37-40), as metáforas da água e da fonte recobriam, não somente o mundo

43. Aqui pode-se problematizar a imagem especular. Por um lado, a desconfiança em relação a ela decorre do excesso de semelhança, da imitação muito perfeita da realidade, o que provoca uma confusão entre imagem e modelo. O mito de Narciso, em Ovídio, é emblemático desta experiência, na qual o duplo toma o lugar do ser. Por outro lado, a experiência do espelho torna-se a metáfora da contemplação indireta daquilo que escapa ao conhecimento imediato. $\mathrm{Na}$ Antiguidade, e em Plotino, inclusive, a reflexão especular é metáfora da reflexão da alma (WUNENBURGER, 1997, p. 170-172).

44. De acordo com Brisson (in: PLOTIN, n. 493, 242), ao final do mito de Er, Platão faz uso do simbolismo do rio do Lete (esquecimento) exatamente para fazer compreender que a memória pertence à alma, sendo a natureza fluida e móvel do corpo um obstáculo à memória. 
físico, mas também o suprassensível. Assim, por exemplo, ele lembra que Marco Aurélio e Sêneca referem-se à fonte do Bem. Nos escritos herméticos, Deus é a fonte de todas as coisas. Filo de Alexandria considera a razão fonte da sabedoria e Deus fonte da sabedoria e da vida. Plotino faz uso da metáfora da fonte para se referir ao Um e ao mundo inteligível (III, 8 [30] 10, 5-10) ${ }^{45}$. Porém, é mister constatar que a imagem da água transmite uma ideia de mobilidade não-adequada à estabilidade do mundo inteligível, de tal maneira que, à figura não-nomeada, que se perde no elemento líquido, símbolo da matéria, Plotino opõe Odisseu, o qual, escapando ao elemento líquido, consegue reencontrar sua querida pátria ${ }^{46}$.

Finalmente, o mito do anônimo ilustra o movimento de paixão da alma pelo seu próprio reflexo. Trata-se, portanto, de uma paixão própria da alma humana esquecida da sua verdadeira natureza; então ela considera seu reflexo como realidade, não percebendo ser ela mesma a fonte de onde provém a imagem. $\mathrm{O}$ erro de almas desse tipo vem de uma certa fadiga em viver na perspectiva da totalidade, com o olhar fixo no vasto horizonte do todo (HADOT, 1976, 247).

45. Talvez Plotino se tenha inspirado numa conhecida passagem do Fedro 245 c 9, na qual Platão afirma que a alma é princípio e fonte do movimento.

46. Plotino menciona Odisseu uma única vez nas Enéadas, exatamente logo após ter aludido ao anônimo, no tratado Sobre o belo. As duas figuras aparecem, portanto, em uma relação de oposição: enquanto uma se abisma no sensível, a outra foge das belezas sensíveis em direção à sua querida pátria, o Um. O não nomeado representa o exemplo a não ser seguido. Odisseu, nomeado, é o exemplo a ser seguido: o do homem em vias de purificação. 
São almas que se ocupam apenas das coisas relativas ao corpo, e que vivem um amor desviado, ou, em outras palavras, uma mera paixão, pois o amor é sempre um movimento em direção ao alto. Assim, cumpre lembrar que Eros, o amor, é um intermediário entre a Alma e o Intelecto, como o olho do amante é um intermediário entre o amante e o amado. $\mathrm{O}$ olho, enchendo-se da beleza do amado, permite ao amante ver o amado. Isso significa que o olho recebe a impressão da beleza, enquanto a alma percebe a forma do belo. Depois de ver a forma do belo, através da visão do outro, a alma retorna a si, converte-se ao seu interior, unida ao Intelecto. Ao encontrar-se a si mesma, nessa contemplação intelectiva, a alma finalmente como que se perde no Um. A alma desse modo amorosa desliga-se do corpo e, na solidão, foge em direção ao Só ${ }^{47}$. Mas, como nota Hadot (1976, 254), essa experiência não consiste em uma experiência de si, mas de tornar-se um outro. Tornar-se Um permanecendo si-mesmo. Finalmente, pode-se dizer que, nas Enéadas, essa figura sem nome desconhece Eros, como desconhece necessariamente a si mesmo em profundidade, no sentido da mais alta metafísica plotiniana.

47. A alma amorosa recebe seu amado somente só; subitamente ele aparece nela, nada há entre ela e ele; eles não são mais dois, os dois fazem apenas um; ela não sente mais seu corpo, pois está nele (VI, 7 [38] 34, 7 ss.). 
(Página deixada propositadamente em branco) 
8.

\section{ZEUS, FIGURA POLISSÊMICA}

7 eus é uma das figuras míticas mais interessantes das Enéadas, não tanto por serem fartas as alusões ao chefe do Olimpo, mas principalmente porque tais alusões 1) permitem entrever a polivalência da figura mítica, uma vez que Zeus representa a Alma, a alma do mundo, o demiurgo, o Intelecto e o Um. 2) A figura de Zeus é apresentada em discursos genealógicos, onde intervém o esquema de parentesco. 3) Mas a figura de Zeus também aparece em discursos não-genealógicos, onde ele representa a alma do mundo, o demiurgo, ou ainda o rei do universo, o chefe que é seguido por seus soldados, o companheiro de Minos ou ainda de Díke. 4) Finalmente, a figura de Zeus é mencionada sem ser interpretada, tendo o valor de metáfora, no exemplo da escultura de Fídias. Além dessas ocorrências, cabe observar que a palavra Zeus também é registrada algumas vezes no léxico de Sleeman e Pollet como mito ${ }^{1}$,

1. Ver I, 4 [46] 7, 24; III, 1 [3] 7, 20; II, 2 [47] 3, 16; V, 3 [49] 7, 13. 
mas, na verdade, compõe uma expressão comum nos diálogos de Platão: Por Zeus! (nè Día). Neste capítulo, serão estudados discursos não-genealógicos onde se encontra a figura de Zeus. No primeiro deles, Zeus é associado ao demiurgo, que corresponde ao Intelecto e a aspectos da Alma. Depois, Zeus é equiparado ao Um, na menção ao mito de Minos, o qual assume o papel da alma humana. Associado a Díke, Zeus figura o Intelecto, enquanto a personificação da justiça representa a sabedoria inata do Intelecto. Por fim, a metáfora do Zeus de Fídias permite retornar à questão da beleza e voltar ao ponto de partida deste estudo, tanto metodologicamente, através da análise de uma metáfora visual, como epistemologicamente, retomando a relação entre mito e imagem plástica. Com isso, temse a ocasião de mais uma vez tematizar a relação entre o mito e a faculdade da imaginação.

\section{ZEUS: DEMIURGO E ALMA DO MUNDO}

No tratado IV, 4 [28], Zeus é mencionado representando o demiurgo e também a alma do mundo, no contexto da investigação acerca da memória. De fato, considera-se que os tratados IV 3-5, na ordem sistemática, ou 27-29 na ordem cronológica, formavam inicialmente um grande tratado sobre a Alma, no qual variegadas dificuldades em torno da Alma, incluindo a alma do mundo e as almas humanas, são discutidas ${ }^{2}$.

2. Brisson (in: PLOTIN, 2005, 13) declara que estes três tratados produzem a exposição mais completa da doutrina plotiniana da Alma e de todas as dificuldades tradicionalmente ligadas a ela. 
Zeus figura no segundo tratado desse grupo, quando Plotino faz a seguinte perquirição: "O discurso investiga se a alma dos astros, em geral, e, em particular, a do sol e da lua têm memória, e finalmente se a alma do universo, e ousaria intrometer-se ainda <em investigar acerca $>$ da memória do próprio Zeus" (IV, 4 [28] 6, 4-8). Ou seja, em outros termos, Plotino enseja verificar se os astros, a natureza e Zeus têm memória. Esse passo do tratado, no entanto, remete a um tema apresentado anteriormente, segundo o qual os seres impassíveis e eternos não possuem memória ${ }^{3}$. Que representa Zeus nesse contexto? A resposta virá algumas páginas adiante, nas quais serão atribuídos dois sentidos a Zeus: demiurgo e alma do mundo.

Em IV, 4 [28] 9, 9, Zeus é comparado ao "demiurgo mais sábio" (dēmiourgòs sophốtatos). Ele é aquele que ordena e administra tudo para sempre (IV, 4 [28] 9, 1) $)^{4}$. Ele, segue Plotino, possui "uma alma régia e um intelecto régio", que pode prever os acontecimentos, supervisionar o que está ocorrendo, e governar os ciclos cósmicos. Sendo muito numerosos tais ciclos, ele deveria guardar tudo isso na memória, afinal ele calcula e combina os ciclos, quantos deve haver e como eles continuarão se produzindo. $\mathrm{O}$ problema da memória

3. "Se o que pertence à memória é algo adquirido, que seja um ensinamento, ou que seja uma afecção, a memória não pode surgir nos seres impassíveis nem nos intemporais" (IV, 3 [27] 25, 10-13).

4. Descrição inspirada em Platão, Fedro, 246 e 4-5. Numênio diz que deus demiurgo é o chefe que circula no céu, noção semelhante a que Plotino desenvolve (NUMÊNIO, frag. 12 des Places).

5. Expressão de Platão, Filebo, 30 d 1-2, citada também em III, 5 [50] 8, 10-11, onde Zeus é identificado com o Intelecto. 
dos ciclos cósmicos é importante para Plotino, porquanto traz à tona a questão da eternidade do universo. Esta é a base da segunda parte do argumento (IV, 4 [28] 9, 10-18). Com efeito, se o número de ciclos fosse limitado, o universo teria tido um começo no tempo. Por outro lado, se fosse infinito, Zeus não poderia conhecer o número das próprias obras. A solução apontada por Plotino é que Zeus sabe que sua obra é única e que sua vida é única pela eternidade (zōè $a e \hat{l})$, e, nesse sentido, é infinita. Assim, a multiplicidade do universo não é obstáculo para que sua atividade seja única.

Até aqui tem-se uma associação entre Zeus e demiurgo. A questão que se impóe agora é interpretar a figura do demiurgo. Surgem, então, dois problemas: o primeiro é que demiurgo é um nome comum e um nome próprio, já em Platão, e em Plotino continua sendo ${ }^{6}$. Por outro lado, a figura do demiurgo produtor do mundo no Timeu, que é classificado por Platão como um discurso verossímil, deu margem para certos exegetas antigos o interpretarem alegoricamente ${ }^{7}$. Admitindo-se a polivalência das figuras míticas, nas Enéadas, e considerando o demiurgo também como

6. Por exemplo, no Timeu, demiurgo é nome comum em 28 a, mas torna-se nome próprio na medida em que Platão o designa como "deus", em 30 a. Há também o verbo demiurgeîn, o qual tanto Platão como Plotino utilizam no sentido comum.

7. Lacrosse $(2003,269)$ observa que o Timeu foi considerado por alguns exegetas antigos como uma alegoria mítica versando sobre um engendramento que não é temporal, um modo de falar não pondo em causa a eternidade do universo. Segundo ele, Plotino se inscreve nesse grupo. 
uma espécie de figura mítica ${ }^{8}$, não há razão para considerar que essa figura tenha um sentido unívoco nos tratados. Embora, em um tratado cronologicamente anterior, Plotino afirme claramente que o demiurgo corresponde ao Intelecto (V, 9 [5] 3, 25-26), o mesmo não parece poder aplicar-se aqui, pois ao Intelecto não poderia ser imputado o governo do universo, que cabe à Alma. Outrossim, no tratado V, 1 [10], há um deslizamento de sentido da figura do demiurgo. Primeiro, ele é associado claramente ao Intelecto: o demiurgo fabricar a Alma em uma cratera representa o engendramento da Alma pelo Intelecto (V, 1 [10] 8, 5-7). Mais adiante, ele reaparece como força demiúrgica na Alma (V, 1 [10] 10, 29-30). Depois, em III, 9 [13] 1, Plotino indaga acerca da existência do demiurgo. Ele não aceita nem recusa abertamente sua existência; apenas analisa suas operaçóes e indica a quem mais convenientemente correspondem. Dividir e refletir pertencem à Alma, que se divide em almas múltiplas, o que resulta na condição prévia para a operação de divisão? Além do mais, diferente do Intelecto, que não é discursivo, a Alma possui o pensamento discursivo, donde surge a reflexão. Situado, portanto, através das atividades da Alma, este demiurgo de III, 9 [13] semelha ao

8. Nada impede dizer que se trata de um mito filosófico, para usar a expressão de Cilento $(1960,250)$, ao referir-se aos mitos cunhados pela imaginação de Platão.

9. Este tratado sublinha o caráter anfíbio da Alma, que se divide nos corpos, mas permanece indivisa no inteligível. Ver também IV, 8 [6] 4, 32 e IV, 2 [4] 1, 33. É mister lembrar que Plotino palia a divisibilidade da Alma, conforme visto no início deste estudo. 
demiurgo do tratado IV, 4 [28], que também cumpre funções da Alma: supervisionar e governar. Por conseguinte, voltando à correspondência entre Zeus e demiurgo, se este, através de suas funções, pode ser associado à Alma, Zeus, por extensão, também pode sê-lo.

Mas, no capítulo 10, Plotino surpreendentemente desdobra o significado de Zeus: "Do princípio ordenador falamos que é duplo: ora <falamos dele> como demiurgo, ora como alma do mundo; assim também falando de Zeus, ora nos referimos a ele como demiurgo, ora como o princípio que dirige o universo" (IV, 4 [28] 10, 1-3). Aqui novamente há um deslizamento de sentido quanto à figura do demiurgo, do qual "é mister subtrair o antes e o depois, a fim de lhe dar uma vida única, imutável e intemporal" (IV, 4 [28] 10, 4-6). Liberado das suas tarefas, o demiurgo agora parece associar-se ao Intelecto, caracterizado semelhantemente a essa nova definição da vida do demiurgo. Então Zeus pode corresponder, por um lado, ao Intelecto-demiurgo, por outro, à força demiúrgica da Alma ou, ainda, à alma do mundo, que dirige o universo. Quanto à questão da memória de Zeus, posta inicialmente, já se sabe que, entendido como demiurgo, Zeus não possui memória. Quanto à alma do mundo, na medida em que sua atividade produtiva e seus produtos são simultâneos, e não sucessivos, não há lugar para memória ${ }^{10}$. Isso implica uma identidade entre a natureza e a providência na

10. Ver IV, 4 [28] 12. Sobre o assunto pode-se consultar o artigo de BRISSON (2004, 23-40). 
alma do mundo (IV, 4 [28] 13-14). Como mostrou Brisson $(2006,25)$, o fato de Zeus não possuir memória, seja ele entendido como demiurgo ou como alma do mundo, tem algumas consequências: o mundo não tem começo, e a produção das coisas sensíveis se faz no âmbito de um processo permanente e, de algum modo, automático.

\section{ZEUS, MINOS E DÍKE}

Se, no tratado IV, 4 [28], Plotino interpreta a figura de Zeus, ao fazê-la corresponder ora ao demiurgo, ora à alma do mundo, o mesmo não ocorre em VI, 9 [9] 7, 21-26, onde menciona Zeus e Minos. Aqui Plotino parece ilustrar o discurso anterior do tratado com o mito. O capítulo em que as figuras de Zeus e Minos aparecem trata da contemplação do Um pela alma humana, mostrando que ela deve voltar-se para dentro de si mesma, a fim de contemplá-lo. Plotino fala para uma segunda pessoa, indeterminada, como se pode notar logo no início do capítulo: "Póe-te voltado para elas e, a partir delas, contempla" (VI, 9 [9] 7, 2 - trad. Brandão), em um tom que pode ser considerado exortativo. Nesse caso, o mito poderia ter uma função retórica persuasiva.

Tradicionalmente, Minos é considerado filho de Zeus e de Europa, tendo sido criado por Astérion, rei de Creta. Após a morte deste, Minos reinou em Creta, reputado como um soberano justo e brando, que criou excelentes leis, inspiradas diretamente por Zeus, a quem ele encontrava de modo regular a cada 
nove anos, na caverna do Ida em Creta, onde recebia suas diretrizes ${ }^{11}$. Na passagem em que ele é mencionado, nas Enéadas, Plotino diz que a alma, tendo estado com o Um, retorna anunciando a outrem a convivência (synousía) que teve (VI, 9 [9] 7, 22-24) ${ }^{12}$.

Tal convivência é talvez a de Minos, o qual se diz que se fez "familiar de Zeus"13 e, lembrando-se, estabeleceu imagens dessa convivência - as leis -, plenificando esse estabelecimento das leis com o toque divino (VI, 9 [9] 7, 23-26 - trad. Brandão).

Donde se deduz que Zeus equivale ao Um, e Minos à alma humana que conviveu com o Um e voltou para contar aos outros como é tal convívio. A forma segundo a qual ele conta é através das imagens (eídōla) que são as leis. Essa passagem foi mencionada por aqueles que desejavam encontrar uma posição política em Plotino. Assim, por exemplo, O’Meara (1992, 508) considera que, nessas linhas, "Plotino vislumbra uma legislação divinamente inspirada, uma expressão política da vida divina, uma comunicação do Bem que é o Um”. Contra essa interpretação pode-se alegar, com Laurent $(1999,98)$ que, segundo Plotino, o essencial para Minos não é legiferar, mas sim encontrar-se com

11. Encontram-se menções a Minos também em Homero, Odisséia, XI, 568; XVII, 523; XI, 568. Ilíada, XIII, 448 ss., XIV 322.

12. Sobre a convivência com o divino, ver PLATÃO, Leis, I, 624 b 1 ss., onde é narrado o mito de Minos.

13. Ver HOMERO, Odisséia, XIX, 178-179. 
Zeus. Para compreender a posição deste último, fazse mister acompanhar as linhas seguintes à passagem supracitada, nas quais é dito: "Na verdade, também não considerando digno dele os assuntos políticos, sempre quis permanecer no alto, o que também é o desejo daquele que viu muito" (VI, 9 [9] 7, 26-28 trad. Brandão). O desejo de Minos, fundamentalmente, seria permanecer junto ao pai, mas, não podendo, ele expressa, através das leis, a imagem dos encontros com Zeus, sem que a atividade política seja mais importante que os encontros com Zeus. Até porque, tais imagens (eídōla) parecem ser icônicas, isto é, imagens passivas, ainda que elas possam sugerir uma atividade a outros homens. Assim, a metáfora do legislador aqui não remete a uma atividade política, mas, antes, à própria função do dialético, que, tendo contemplado a unidade, deve sinalizar o caminho para outros que buscam a mesma coisa. Por fim, cabe observar que Jâmblico (Vita di Pitagora, 27) retoma a figura de Minos, associado com Pitágoras retirado em uma gruta isolada, representando a saída do mundo.

No tratado V, 8 [31] há uma menção a Zeus associado à figura de Díke. Aqui também a referência às figuras míticas não é interpretada, mas, antes, parece ilustrar o que acaba de ser dito. Tal menção encontrase no capítulo 4, no qual Plotino descreve, em tom lírico, a vida feliz do Intelecto. Assim, ele assegura que o inteligível é um mundo de pura luz, que cada inteligível contém em si todos os outros e que todos são uma única coisa. Quem é agudo da vista como Linceu, que via as vísceras da terra, é capaz de ver o todo, 
pois este mito alude aos olhos que veem lá no alto, explica Plotino (V 8 [31], 4, 26). Nesse caso, como se pode ver, Plotino, de certo modo, interpreta o mito de Linceu, situação que não se nota na outra alusão a mitos no mesmo capítulo. Plotino continua a descrição da vida do Intelecto, dizendo não haver cansaço na contemplação de lá, pois aquela é uma vida perfeita. A vida lá é sabedoria (sophía), mas não do tipo que se adquire com raciocínios. Trata-se do saber primeiro que não provém de outra coisa, pois o ser mesmo é saber, não havendo primeiro um ser, depois um ser que sabe (V, 8 [31] 4, 1-39). É então que surge a menção ao mito de Zeus e Díke:

Por isso nenhuma <sabedoria> é maior e a ciência em si aqui se senta ao lado do Intelecto pelo fato de que se mostram juntos, como dizem, pela imagem de Díke que senta <ao lado $>$ de Zeus ${ }^{14}$. Pois todas as coisas deste tipo lá são como esculturas que podem ser vistas por elas mesmas, de maneira que "seja espetáculo de espectadores extremamente felizes" (V, 8 [31] 4, 39-44) - trad. Soares, ligeiramente modificada) ${ }^{15}$.

Aqui Zeus significa o Intelecto, e Díke parece remeter à sabedoria inata do Intelecto. A associa-

14. Possível referência a PÍNDARO, Olimpicas, 8, 21; SÓFOCLES, Édipo em Colono, 1382 e PLATÃO, Leis, IV, 716 a.

15. A citação entre aspas, ao final da passagem, refere-se a PLATÃO, Fedro, 111 a 3. 
ção entre a personificação da justiça e a sabedoria pode ser justificada, através das alusões ao Fedro, que parecem reger todo o tratado. De acordo com o Fedro 250 b, justiça, sabedoria e ciência são os objetos próprios da contemplação do lugar supraceleste. Mas, além disso, pode-se justificar tal associação pela teoria das virtudes do próprio Plotino, notadamente quando ele assimila a justiça à sabedoria na forma inteligível das virtudes. Segundo Plotino, as virtudes pertencem à alma (I, 2 [19] 6, 15-17), enquanto suas formas, que receberam no neoplatonismo posterior a designação de "virtudes exemplares", situam-se no Intelecto ${ }^{16}$. Nesse nível, com efeito, a sabedoria prática, a coragem, a temperança e a justiça não são virtudes: são a atividade do Intelecto.

16. Autores neoplatônicos posteriores receberam e conservaram as principais orientaçôes da teoria plotiniana das virtudes, mas formularam sistematicamente os graus de virtude. Tal formulação aparece por primeiro em Porfírio (Sentenças 32, que parece ser um comentário ao tratado Sobre as Virtudes) e Macróbio (Comentário sobre o sonho de Cipião, I, 8). Porfírio, Sentença 32, estabelece a seguinte divisão: virtudes cívicas, virtudes purificativas, virtudes purificadas, virtudes exemplares. Plotino mesmo não apresenta esses graus assim distribuídos; para ele, as ditas virtudes purificativas e purificadas parecem fundir-se no próprio processo catártico da alma elevando-se rumo ao Intelecto. A formulação em graus resulta certamente de uma espécie de sincretismo com elementos vindos da reflexão estóica, que dedicava lugar de destaque à ideia de progresso moral (FLAMAND, in: PLOTIN, 2003, 426). Ou, não se querendo adotar a ideia de sincretismo, poder-se-ia dizer que trata-se de uma combinação com elementos de origem estóica. Acerca da relaçáo entre estes e o texto plotiniano, ver TROUILLARD $(1955,189$ ss). 
Não podem ser virtudes, uma vez que o Intelecto está eternamente contemplando o Um. E as virtudes constituem de fato um devir progressivo, um processo sucessivo de elevação em direção à unidade e ao Um. Portanto, Plotino considera que o Intelecto não tem virtude, mas tem as formas inteligíveis delas. Estas são: a intelecção, que é a forma da sabedoria prática, é ciência e saber; a temperança é estar voltado para si mesmo; a função própria, isto é, a forma da justiça, é o cumprimento da função própria do Intelecto; a imaterialidade é o análogo da coragem (I, 2 [19] 7, 4-6). Portanto, se essas quatro formas estão no Intelecto, e se lá cada uma contém a outra, não é absurdo que Plotino aluda a uma delas com a personificação mítica de outra.

Finalmente, é interessante notar a associação entre mito e imagem, dessa vez mediante a expressão katà mímèsin, seguida da fórmula hoîon agálmata. $\mathrm{O}$ termo grego agálmata pode significar esculturas, mas também imagens, como já é sabido. A ideia em questão na frase é que todas as coisas do intelecto podem ser vistas umas pelas outras. Traduzir por esculturas remete ao começo do tratado, precisamente à famosa passagem da escultura de Zeus feita por Fídias. Essa escultura possuía em uma das mãos uma pequena estátua de Díke, o que permite supor que a alusão a Zeus e Díke, juntos, não remete somente a textos literários, mas a um imaginário bastante conhecido nos tempos de Plotino. Isso faz voltar à expressão katà mímésin que poderia aludir às representações plásticas desse mito. 


\section{O ZEUS DE FÍDIAS}

A metáfora do Zeus de Fídias possivelmente é uma das mais conhecidas dos tratados. Os dois personagens em questão, Zeus e Fídias, são citados por toda cultura helênica. Zeus, o chefe do Olimpo, dispensa apresentaçōes. Fídias, considerado o maior escultor da Grécia clássica, ficou conhecido por diversas esculturas nas quais representava deuses, notadamente uma, na qual figurou Zeus. O que hoje se sabe sobre essa escultura monumental de Fídias foi transmitido quase que exclusivamente por escritos e representações em moedas. Entretanto, o escopo deste estudo não é exatamente a obra de Fídias enquanto tal. Serão, pois, deixadas de lado essas instigantes descrições, e não serão vistas as fontes iconográficas. É interessante notar, todavia, que as esculturas de divindades tinham por referência o ensinamento transmitido pelas epopéias sobre os deuses, sendo, portanto, elas próprias, um tipo de alegoria visual. A propósito, há em Estrabão uma interessante alusão ao modelo empregado por Fídias, acorde com esse ponto. Trata-se da resposta de Fídias a seu sobrinho, o pintor Panainos, que trabalhou na decoração da escultura, em especial na pintura das vestes. Panainos perguntou segundo qual modelo (parádeigma) Fídias faria a imagem de Zeus (tè̀v eikóna tou Diós); "o escultor respondeu: segundo aquele que Homero deixou nos versos seguintes: Ele disse, e, com suas negras sobrancelhas / O filho de Cronos fez um sinal; / Sobre sua cabeça imortal / 
flutuavam seus cabelos divinos; / O imenso Olimpo estremeceu" 17 .

Observe-se, contudo, que, dentre os filósofos, já em Platão (Protágoras, 311 c-e; Menon, 91 d) Fídias é mencionado como paradigma do escultor. Séculos mais tarde, sua arte é exaltada por Sêneca e Epicteto ${ }^{18}$. Este último, por exemplo, recomenda uma visita a Olímpia para ver a obra de Fídias, dizendo ser uma infelicidade morrer sem tê-la visto. Com efeito, essa escultura deve ter sido tão impressionante, que, em certos textos filosóficos, aparece como paradigma de teoria do belo na qual a arte não copia a natureza, mas remonta a um modelo inteligível ${ }^{19}$. A mais antiga menção a Fídias, com tal sentido, parece ter sido feita por Cícero, em Sobre o orador, 2-8, 3-9, que possui

17. Para todo o diálogo entre Fídias e Panainos, ver ESTRABÃO, Geografia, VIII, 3, 30, 29-35.

18. SÊNECA, Epistolas a Lucílio, 85, 41; Dos beneficios, II, 33, 2-3. EPICTETO, Manual, II, 8, 18. Com efeito, a lista de autores que mencionam esta obra inclui, além de Cícero, Estrabão, Sêneca, Epicteto, também Plínio, Dio Crisóstomo, Plutarco, Luciano, Pausânias, Orígenes, Filostrato, Plotino e Proclo. A maioria desses autores faz referência à escultura de Zeus para ilustrar um ponto preciso da religião, da arte ou da geografia, sem que sirva de base a uma teoria da arte (KUISMA, 2003, 115).

19. Pépin (1992, 331-334) apresenta um dossiê com referências a Fídias, anteriores a Plotino, que parecem inseri-lo nessa linhagem de autores que já haviam esboçado a teoria segundo a qual a arte remonta a um modelo inteligível, diferenciando-se, sob tal aspecto, da teoria mimética do livro X da República de Platão. Panofsky (1994, 15-34), antes de Pépin, havia apresentado Cícero como aquele que primeiro inverteu a concepção platônica de arte. Essa interpretação, com uma terminologia variada, aparece também em De Keyser (1955, 88-89) e Wallis (1995, 86-87), dentre outros. 
algumas semelhanças com a teoria plotiniana. Com efeito, segundo Cícero, não existe nada tão belo cujo original (ore), de que é imagem, não seja ainda mais belo. No entanto, não se pode perceber o original pelos sentidos; o original é tão-somente conhecido na mente (mente) e pelo pensamento (cogitatione). Por isso, é possível pensar em esculturas mais belas que as do próprio Fídias, que são o que há de mais perfeito no seu gênero. Quando Fídias fez seu Zeus ou sua Atena, continua Cícero, ele não considerou um homem qualquer, que poderia ter-lhe servido de modelo. Fídias possuía em sua mente a exímia beleza, a qual tomava por modelo para a sua arte. A partir dessa passagem de Cícero, pode-se entrever que algo da teoria plotiniana do belo existia bem antes de Plotino: a noção de uma beleza perfeita além da percepção dos sentidos, acessível ao pensamento e que serve de modelo ao artista. Sem entrar nos detalhes da teoria ciceroniana, é essencial mencionar um problema que parece impor-se a partir dessa passagem do orador romano, e que foi assim expresso por Panofsky (1994, 24):

Se essa imagem interior, que representa o objeto próprio da obra de arte, não é nada mais que uma representação vigorosa no espírito do artista, uma representação pensada, o que lhe garante essa perfeição pela qual deve prevalecer sobre os fenômenos da realidade? E, inversamente, se ela possui de fato essa perfeição, não seria então algo bem diferente do que uma simples representação pensada? 
Para responder a essa questão, um caminho possível foi "conferir a esta alta perfeição uma legitimidade metafísica” (PANOFSKY, 1994, 24). Esta solução encontra-se em Plotino. O Zeus de Fídias é mencionado uma única vez nas Enéadas, no primeiro capítulo do tratado V, 8 [31], Sobre a beleza inteligivel. Diz Plotino:

Mas se alguém despreza as artes porque estas produzem imitando a natureza, antes de tudo precisa ser dito que também as coisas da natureza imitam outras coisas. Em seguida, é preciso saber que não imitam simplesmente isto que se vê, mas se elevam aos lógoi donde provém a natureza. Além disso, é preciso saber também que as artes produzem muitas coisas delas mesmas e completam isso que carece de alguma coisa porque as artes possuem a beleza. Assim também Fídias fez seu Zeus, sem referência a nada de sensível, mas o apreendeu tal qual ele seria, se Zeus quisesse aparecer-nos visivelmente (V, 8 [31] 1, 32-40 - trad. Soares modificada) ${ }^{20}$.

O primeiro ponto a observar é que a arte produz, elevando-se aos lógoi donde provém a natureza, e não imitando a natureza. Significa, portanto, que o artista

20. Sobre o pronome indefinido tís nessa passagem, embora pareça referir-se a Platão, precisamente ao livro X da República, talvez entre no âmbito geral do indefinido aplicado a alguém de opiniāo contrária a de Plotino, como um gnóstico, por exemplo. Pépin (1982, 313-314) sugere que se refira a Platão. 
tem por referência um modelo inteligível, e não sensível. Donde, pode entender-se que “a 'imagem' que Fídias traz em seu interior não é apenas, conforme o sentido da metafísica plotiniana, a representação de Zeus, mas sua essência" (PANOFSKY, 1994, 27). Ou seja, Fídias contempla os lógoi que são as formas inteligíveis difundidas na Alma, os quais verterão para a parte inferior da mesma, produzindo a natureza. Portanto, através desses lógoi, ele contempla a própria forma de Zeus, e essa forma o artista tenta transferir para a escultura. Ademais, se Fídias é capaz de manifestar, mediante a escultura, a própria beleza de Zeus, este exemplo também mostra que a beleza sensível é uma presença (parousía) do divino, logo o visível pode sinalizar o invisível sob um modo diferente daquele da falta e da deformação (LAURENT, 1999, 140).

Pode-se, a partir dessas considerações, indagar sobre o que significa a transferência da beleza, contemplada pelo artista, para a arte. Para responder a essa questão, é preciso compreender, preliminarmente, que, para Plotino, todo corpo, seja ele natural ou não, constitui-se como um composto de forma e matéria. A forma pertence ao mundo inteligível, por conseguinte, é invisível. A matéria do mundo sensível, também invisível, por sua vez, é algo indeterminado e privado de forma, que, não obstante, pode receber a forma ${ }^{21}$. Plotino se refere

21. Felix Ravaisson $(1963,383)$ diz: a matéria “é o que recebe toda forma e toda determinação, e que, por consequência, é em si mesma totalmente informe e indeterminada. Não é, portanto, o corpo; não é mesmo a simples quantidade (...). É o infinito, o não-ser, como Platão a nomeava”. 
a esta matéria como um "aquilo sobre o que" (eph' hôi) a forma se aplica (II, 4 [12] 4, 11). Quando o artista toma um certo material no qual pretende realizar uma obra, por exemplo, o bronze ou a pedra para fazer uma escultura, este material é, ele próprio, corpo, portanto, possui matéria e alguma forma. Mas não a forma da arte, isto é, a forma que o artista contempla e vai transferir para o material. Sobre esse ponto vale citar outro exemplo mencionado por Plotino um pouco antes do de Fídias, e também célebre, no qual são comparados dois blocos de pedra, situados ao lado um do outro:

Um sem proporção e sobre o qual a arte não interveio e o outro já transformado pelo domínio da arte na escultura de um deus ou ainda de um homem, de um deus como uma Graça ou uma Musa e de um homem, não qualquer um, mas aquele que a arte produziu a partir de tudo o que há de belo. Aquela pedra que atingiu a beleza de uma forma devida à arte aparecerá bela, não porque é pedra - pois seria igualmente bela também a outra - mas pela forma que a arte infundiu (V, 8 [31] 1, 6-15 - trad. Soares modificada).

Para compreender esse exemplo, é preciso observar que, segundo Plotino, as pedras possuem um pouco de beleza, na medida em que fazem parte da natureza e, portanto, são expressão do lógos. Porém, dentre os seres naturais, as pedras e rochas são os que menos possuem beleza; são consideradas realidades ontologi- 
camente mais pobres, pois são imóveis e menos autossuficientes que os vegetais e os animais, uma vez que as pedras não reproduzam e parecem destinadas a uma fragmentação progressiva (LAURENT, 1999, 145)22. A relação que Plotino estabelece entre as pedras brutas e uma participação de menor grau no ser e na forma, isto é, na vida que é movimento, nada mais parece que um eco do pensamento grego em geral. Para os gregos, as pedras mudas, cegas, frias e opacas, têm relação com a morte, ao contrário das pedras preciosas, consideradas vivas, porque cintilam, refletem a luz ou se deixam penetrar inteiramente por ela. No entanto, as pedras esculpidas recebem significados divinos, quando assumem a forma de deuses, por exemplo. Por conseguinte, as esculturas religiosas inserem a presença divina no mundo humano, estabelecendo, assim, uma comunicação entre homens e deuses, mas, ao mesmo tempo, marcando uma distância, na medida em que acusam o incomensurável entre a força sagrada e tudo o que aos olhos dos homens a manifesta de maneira necessariamente inadequada (VERNANT, 2002, 394-398).

Ora, na primeira passagem das Enéadas exposta nesta seção, Plotino dizia que "as artes produzem muitas coisas delas mesmas e completam isso que carece de alguma coisa, porque as artes possuem a beleza" (V, 8 [31] 1, 33-40). Pois bem, essa asserção faz referência ao exemplo das pedras, que de fato a antecede. $\mathrm{O}$ que carece de algo pode ser entendido como

22. Ver III, 6 [36], 6, 33 ss., onde Plotino associa as rochas saídas da terra a uma maior carência de ser. 
a pedra em estado bruto, ontologicamente inferior, conforme foi visto. Portanto, a arte a completa, na medida em que lhe dá beleza.

Considerando-se que a causa material da escultura não é indiferente, a forma que ela adquire é igualmente rica em sentido (LAURENT, 1999, 145). No exemplo das duas pedras, as esculturas passam a ter a forma de um deus ou de um homem. No primeiro caso, antecipando o exemplo de Zeus, Plotino nomeia aqui uma Graça ou uma Musa. Ora, como é sabido, a postura de Plotino diante das figuras míticas é, normalmente, exegética. Portanto, cabe indagar o que essas figuras representam. As Graças são divindades da beleza, associadas ao séquito de Apolo. Moram no Olimpo, em companhia das Musas, com as quais por vezes fazem coros. As Musas também são associadas à beleza. São cantoras divinas e também presidem ao pensamento sob diversas formas: eloquência, persuasão, astronomia, história, sabedoria. Assim, esse exemplo parece identificar a beleza divina, representada pelas Graças e pelas Musas, com a beleza inteligível, reforçando, portanto a ideia de que a escultura transfigura, através da beleza da arte, a própria beleza inteligível.

Quanto à escultura da forma humana, não se trata de representar um homem específico. Plotino refere-se àquele homem "que a arte produziu a partir de tudo o que há de belo" (V, 8 [31], 1, 11), isto é, das formas. Com efeito, não se deve compreender a expressão "tudo o que há de belo" (ek pántōn kalôn) segundo a noção de seleção de partes belas de diferentes corpos, conforme uma estória célebre na Antiguidade: 
conta Plínio, o Velho, (História Natural, XXXV, 36) que Zêuxis, para pintar um retrato de Helena, teria escolhido como modelos as cinco mais belas virgens de Crotona, sintetizando no retrato os mais belos elementos de cada modelo. Consoante Plotino, esse procedimento de seleção e síntese remeteria a uma noção equivocada, uma vez que os modelos, sendo humanos, são sensíveis. Ademais, remete à teoria segundo a qual a beleza resulta do acordo das partes entre si. Este é um traço importante da teoria clássica da arte grega, expressa no Cânone de Policleto ${ }^{23}$ e, nas suas linhas gerais, assumida pelos estóicos. Tal teoria é criticada por Plotino, no início do tratado Sobre o belo, I, 6 [1], pois o acordo das partes supõe que o belo seja somente e necessariamente algo composto, e não simples (I, 6 [1], 1, 25 ss). Ora, já foi visto que, para Plotino, o belo sensível consiste em uma presença do Um. Assim, os corpos são belos, porquanto participam da forma. A forma é o princípio de unidade, ou seja, aquilo que reúne a multiplicidade da matéria em um todo unificado (I, 6 [1], 2, 12-23). Por conseguinte, se a arte produz uma bela escultura de homem, a partir de tudo o que há de belo, não se trata, pois, de seleção, mas de contemplação; a expressão ek pántōn

23. Policleto de Argos redigiu, no Vo séc., um tratado sobre arte, denominado Cânone, cujos princípios são ilustrados por uma escultura homônima de sua autoria, identificada ao Doríforo. Os princípios do Cânone fundam-se sobre a noção de symmetría, que não possuía uma função exclusivamente técnica: "ela manifestava a beleza na composição e na harmonia e eliminava assim a rigidez formal arcaica. A articulação recíproca das partes e a lógica constitutiva da construção geral asseguravam a mesma dignidade estética a todos os elementos" (LOMBARDO, 2011, p. 32 ss.). 
kalôn parece corresponder ao movimento ascensional da alma, segundo o qual ela ultrapassa todas as belezas sensíveis em direção à beleza inteligível ${ }^{24}$.

Isto ainda pode ser explicado da seguinte maneira: no caso da arte, Plotino estabelece como que uma escala de níveis da beleza. Primeiro, há a beleza em si, que é a forma inteligível do belo. Depois, a beleza que reside na alma do artista, ou seja, que é por ele contemplada no inteligível. Por fim, a beleza da obra de arte, isto é, a forma que o artista conseguiu transferir da contemplação para o material. Havendo um percurso descendente, é necessário que exista também um ascendente.

\section{DA ESCULTURA AO MITO: A FACULDADE DA IMAGINAÇÃO}

Fídias, como foi visto, ao figurar o deus, o apreendeu (labốn) tal qual ele seria, se Zeus quisesse aparecer visivelmente. Uma última dificuldade consiste em compreender o termo labốn Plotino poderia ter dito que Fídias percebeu ou que imaginou, ou, ainda, que ele pensou Zeus. Entretanto, optou por utilizar um verbo que não faz referência direta a uma faculdade da alma. Com efeito, o verbo lambánō, na língua grega, pode ter o sentido de "ser possuído por um deus". Mas também significa tomar, pegar, compreender, tanto em referência a objetos físicos,

24. Laurent $(1999,147)$ considera que a expressão $e k$ pánt $n$ kalôn corresponde ao movimento descrito no discurso de Diotima, no Banquete, segundo o qual a alma ultrapassa todas as belezas sensíveis em direção à beleza inteligível. 
como conceituais ${ }^{25}$. Essa dupla possibilidade pode ser assim expressa: Fídias apreende, pega Zeus, e Fídias é tomado por Zeus. Parece estar contida no sentido geral do verbo nesta frase, pois, no mesmo ato em que o artista vê o deus invisível, ele como que se identifica com o objeto de sua visão, sendo de certo modo tomado por este objeto de visão.

Aqui é possível lançar a hipótese segundo a qual labốn pode ser associado à imaginação (phantasía) e ao pensamento discursivo. Ora, o pensamento discursivo forma juízos (epikrisis) mediante síntese e separação (synágon kaì diairoûn) de imagens recebidas da sensação ou do Intelecto (V, 3 [49] 2, 7-10). O pensamento discursivo recebe do Intelecto os traços (ikhnê) e as impressões (týpoi); das sensaçōes, recebe as impressōes (týpoi) e as imagens (phantasmáta - V, 3 [49] 2-3). Ou seja, a sensação só pode ser interpretada e compreendida pelo pensamento discursivo, na medida em que as imagens são definidas pelos traços, ou que as impressōes coincidem, ainda que advindas de matrizes diferentes. É como se o pensamento discursivo fizesse coincidir sobre seu próprio plano as imagens vindas de ambos os lados. Por extensão, pode-se aduzir que, se o pensamento discursivo pode emitir um juízo de valor sobre as imaginações, é graças às formas que ele contempla no Intelecto.

Assim, imaginação e pensamento discursivo podem estar incluídos no duplo sentido do verbo labốn

25. Os sentidos do verbo para esta passagem das Enéadas são apprehend, understand, grasp, assume, segundo SLEEMAN \& POLLET (1980, col. 589, lambánein, b). 
naquela frase. Tanto a imaginação como o pensamento discursivo recebem imagens inteligíveis. Mas a imaginação sozinha não parece poder distinguir entre uma imagem sensível e uma inteligível (I, 4 [46], 10, 13 ss), sendo necessário o pensamento discursivo, que faz o cotejo das impressões. Por outro lado, auxiliado pela faculdade da imaginação, o pensamento discursivo determina que tipo de forma visível seja igualmente possível e factível para figurar um ser invisível (KUISMA, 2003, 122-126). Finalmente, a função simbólica de uma forma visível, tal como a escultura de Zeus, é indicar indiretamente o que não é representável literalmente. Isso está próximo do conceito de expressão alegórica.

No caso de Plotino, o mito normalmente afigurase como expressão alegórica, no cerne de uma filosofia do indizível. Como a escultura de Fídias, o mito indica, simboliza a forma que não é apreensível pelos sentidos. E, para além da forma, o mito também simboliza o inefável. Ora, em uma filosofia que situa no alto da hierarquia metafísica algo que não pode ser adequadamente dito, o Um inefável e inominável, a linguagem catafática é sempre aproximada e, de certo modo, é sempre simbólica e enigmática. 


\section{CONCLUSÃO}

Tarkovski considera que a essência do trabalho de

1 um diretor de cinema pode ser definida como esculpir o tempo:

Assim como o escultor toma um bloco de mármore e, guiado pela visão interior de sua futura obra, elimina tudo que não faz parte dela - do mesmo modo o cineasta, a partir de um "bloco de tempo" constituído por uma enorme e sólida quantidade de fatos vivos, corta e rejeita tudo aquilo de que não necessita, deixando apenas o que deverá ser um elemento do futuro filme, o que mostrará ser um componente essencial da imagem cinematográfica (TARKOVSKI, 2010, 72).

No modo como os mitos foram aqui estudados, Plotino aparece como um escultor de mitos. Metafra- 
seando o cineasta, Plotino toma um bloco de mitos e, guiado pela visão interior do mundo inteligível, elimina do bloco tudo o que não faz parte dela. Corta e rejeita tudo aquilo de que não necessita, deixando apenas o que é essencial para a imagem filosófica.

Ao longo da pesquisa, mostraram-se variegados usos e implicações filosóficas dos mitos nas Enéadas. A título de conclusão, é lícito recordá-los. No primeiro capítulo, Metáforas, figuras filosóficas, apresentaramse aspectos gerais da filosofia de Plotino, a partir de certas metáforas, especialmente a do templo e das esculturas. A processão e a contemplação são os dois conceitos filosóficos estudados aqui. Com respeito à via processional, destaca-se o tema do lógos, entendido como princípio de transmissão dos objetos de pensamento para a alma. Este tema é recorrente ao longo da pesquisa, sendo que, nos capítulos seguintes, diferentes aspectos do lógos são estudados. Com relação à via contemplativa, as metáforas servem de mote para explicar diferentes passos do caminho. Assim, por exemplo, a cela do templo onde se situam as esculturas, representa a contemplação do Intelecto, e o ádito do templo simboliza a contemplação do Um. As esculturas referem-se às coisas belas e ao belo sobrepujado. $\mathrm{O}$ deus que habita o templo simboliza tanto o Intelecto, como o Um, o que denota a polivalência das metáforas. A partir das metáforas analisadas, foram abordados temas que concernem ao uso do mito, tais como: 1) a verificação: procedimento segundo o qual uma figura segue à outra, elucidando a mesma dificuldade sob outro ângulo; 2) a polivalência: uma 
mesma figura pode significar diferentes coisas e uma mesma coisa pode ser representada por diferentes figuras; 3) a restrição semântica: fórmulas que advertem que as figuras não devem ser entendidas literalmente. Esses procedimentos sinalizam a inadequação da linguagem ao seu objeto e, ao mesmo tempo, as possibilidades da linguagem em tentar falar sobre o que lhe escapa. Finalmente, notou-se, no início do capítulo, que as metáforas fraturam o ritmo do discurso conceitual, exigindo a atenção do interlocutor. Além disso, aqui se utiliza o termo figuras para designar tanto metáforas, como mitos, buscando denotar certo parentesco existente entre ambos: tanto uns como outros tentam dirigir a intuição à realidade inteligível.

O segundo capítulo, tipos de discurso, ensejava mostra a especificidade dos discursos míticos em relação a outros tipos de discurso nos tratados, versando primeiramente sobre diferentes tipos de discursos mobilizados por Plotino nos tratados, com o escopo de paliar o hiato existente entre o sensível e o invisível. Foram vistos aspectos das formas apofática e catafática da linguagem. Disso depreendeu-se que a linguagem origina-se no Intelecto e que ela é capaz de atingi-lo. Uma vez que a alma humana discorre acerca do Intelecto, é porque foi possível conhecê-lo. Mas a linguagem não consegue falar sobre o Um, que é incognoscível e inefável, a não ser inadequadamente, imperfeitamente, pois o Um não admite atributos. Só é possível falar sobre ele, partindo de nós mesmos, das nossas determinações sensíveis. Nesse sentido, todo discurso posi- 
tivo sobre o Um é metafórico. Ora, Plotino mobiliza estratégias discursivas, não somente para tentar falar sobre o invisível, mas também para persuadir seus interlocutores. Por isso os textos das Enéadas recorrem à retórica, entendida como um discurso contínuo que visa persuadir o interlocutor, mas que também o atinge afetivamente. Desse modo, os mitos inserem-se no contexto mais amplo da retórica, entrando no conjunto dos discursos que se dirigem à parte inferior da alma. Esta se deixa enlevar pelas belezas sensíveis, se deixa apaixonar por elas, mover-se pelas emoções que elas suscitam, e, portanto, a alma inferior é a parte da alma passível de ser convencida. Nesse sentido, os mitos possuem certo caráter anagógico.

Pois bem, os mitos estão compreendidos sob o aspecto retórico dos discursos e nisso eles se assemelham às metáforas. Mas no que se diferenciam dos demais discursos? Este é o tema do capítulo terceiro, discursos míticos. Esse capítulo, fundamentado em uma ampla revisão dos estudos hodiernos que tratam do mito em Plotino, dá um passo sutil para além das conclusōes avançadas pelos mesmos. Considera-se, aqui, que Plotino faz da estrutura genealógica dos mitos uma forma discursiva que é imagem da temporalidade do pensamento discursivo da alma humana. Portanto, desvendar o sentido dos discursos míticos equivale a descobrir o próprio tempo psíquico, que é imagem da eternidade. Para se chegar a essa pesquisa, primeiro se tentou compreender a genealogia como forma mítica, que já em Hesíodo apresenta-se como um modo de expressar a natureza própria de cada ente, seu modo de vida, sua 
posição hierárquica na estrutura universal. Sob esse aspecto, Plotino se insere em uma longa tradição mítica. Mas ele se diferencia, ao permitir uma associação entre a genealogia e o tempo da Alma. Além disso, a genealogia para ele corresponde a um certo tipo de discurso (lógos). Para se compreender a especificidade desse lógos, foi necessário analisar o mito do nascimento do tempo, que também permite compreender que o tempo é vida da Alma e imagem da eternidade. Ora, daí decorre a noção de tempo psíquico, e a relação que se estabelece entre o tempo do mito como imagem do tempo psíquico, e este como imagem da eternidade. Essa noção esclarece a pesquisa proposta. Mas, resta ainda uma dificuldade: os discursos míticos dividem em genealogias, cabendo ao interlocutor reunir o que foi dividido, para que se compreenda o sentido dos mitos. Dividir e reunir são procedimentos dialéticos. Esse paralelismo de termos conduziu alguns estudiosos a confundir, de certo modo, mito e dialética. $\mathrm{Na}$ tentativa de esclarecer esse ponto, foi necessário antes compreender o que é a dialética para Plotino. Não se trata dos discursos dialéticos, que reproduzem os diálogos de aula, mas sim da parte mais preciosa da filosofia, que é de fato um método ascensional, o qual se perfaz através da purificação pelas virtudes. A dialética, através da divisão e da síntese, é capaz de conduzir a alma até ao Intelecto; com a análise, ela situa a alma na unidade, de tal modo que a alma está em condições de contemplar o Um. O mito não tem a terceira parte do método dialético, a análise. Ademais, ele não é, em nenhum momento, relacionado 
com a purificação pelas virtudes. Portanto, não pode ser confundido com a dialética. De modo que o mito consiste em uma prática discursiva capaz de apontar o caminho para a eternidade, mas não em um caminho ascensional completo. Aqui a metáfora do escultor de mitos pode ser problematizada: se é verdade que nas Enéadas a escultura representa o coro das virtudes, e a atividade do escultor remete à atividade purificativa, também parece ser verdade que o mito não aparece relacionado com a purificação. Todavia, se o mito tem um aspecto anagógico e um aspecto belo, não seria ele, finalmente, um degrau na escala da purificação?

A seguir, os dois próximos capítulos tratam dos discursos míticos das Enéadas, visando demonstrar como Plotino articula tais mitos com os aspectos filosóficos sobre os quais eles versam. Portanto, a metodologia utilizada consiste em analisar os mitos e desenvolver os conceitos filosóficos por eles expressos, bem como compreender as relações de hierarquia sob as estruturas de parentesco. No quarto capítulo, discursos sobre Afrodite e Eros, percebeu-se que a maioria dos estudos consagrados a esses mitos nas Enéadas detinham-se no mito de Eros, filho de Poros e Penía, enfatizando, portanto, a exegese dos dados platônicos. E muito poucos estudos versavam sobre os mitos anteriores do tratado, de Eros deus, filho de Afrodite Urânia e de Eros daimōn, filho da segunda Afrodite. Por conseguinte, neste capítulo, tentou-se analisar todos os mitos do tratado III, 5 [50], mostrando que há um fio condutor entre eles. Com efeito, sob esse aspecto, a figura de Afrodite é central, porquanto a Afrodite, cujo nata- 
lício é festejado no jardim de Zeus, ocasiāo na qual Penía, unindo-se a Poros, concebe Eros, reabsorve as duas outras Afrodites: a Urânia e a segunda. Outrossim, esta análise foi pautada pelos seguintes pressupostos metodológicos: a polivalência das figuras míticas e a simultaneidade dos referentes. Dessarte, é possível entender que esse mito apresenta um esquema completo das relações entre a Alma, simbolizada em múltiplos aspectos pelas diferentes Afrodites, e do Intelecto, representado por Cronos e por Zeus. As relaçóes entre a Alma e o Intelecto são explicitadas através de dois conceitos que esses mitos apresentam: o de olhar amoroso (Eros) e o de lógos, cuja polissemia exige que seja representado por diferentes figuras (Póros, o néctar, os esplendores do jardim). O conceito de polivalência, ou ainda de polissemia dos mitos, implica tanto o pluralismo de significados para determinada figura mítica, como a multiplicidade de figuras para uma mesma realidade. Finalmente, esse tratado mostra exemplarmente a fusão de elementos platônicos, teogônicos e cosmogônicos na exegese dos mitos. Plotino, de fato, propõe analisar o que seja o amor a partir de diálogos platônicos, mas também atentando para o que disseram os teólogos, que parecem ser Hesíodo, Homero e os poetas órficos. Ele parece conhecer exegeses correntes à sua época e as ajusta às suas exigências filosóficas. Mas ele alude principalmente a certas passagens do Banquete, em especial ao discurso de Pausânias e ao de Sócrates/Diotima, interpretando-os conforme os postulados da sua própria filosofia. Ademais, do ponto de vista filosófico, ou seja, da exegese dos mitos, as gene- 
alogias de Afrodite e Eros permitem: 1. Compreender detalhadamente o caminho de retorno das almas humanas encarnadas em um corpo ao Um, através do amor; 2. Compreender o fluxo do lógos desde o ato contemplativo do Um pelo Intelecto, quando surge o primeiro lógos, até à enformação da matéria no mundo sensível. Desse modo, o tratado Sobre o amor permite entender as ligações e as interpenetrações entre todos os níveis de realidade.

O quinto capítulo, discursos sobre Urano, Cronos e Zeus, analisa este que é o outro grande mito genealógico das Enéadas. Diferentemente do anterior, este não se encontra em um tratado, mas sim esparso por dois diferentes tratados: V, 1, [10] e V, 8, [31]. Em cada qual, Plotino apresenta aspectos distintos da genealogia. Esses discursos causam um certo desconforto, quando se tem em mente a ideia segundo a qual Plotino interpreta os mitos homéricos e hesiódicos através de Platão, a qual foi sugerida por Pépin, notório estudioso do mito e da alegoria na Antiguidade. Isso porque exatamente o mito da tríade divina é condenado por Platão, como sendo exemplo de grande falsidade. Platão parece nisso ter seguido certos argumentos caros aos detratores de Homero, que consideravam inadequados os fratricídios e outros crimes cantados pelo poeta. Mas, por outro lado, este mesmo mito deve ter sido alvo de numerosas interpretaçôes capazes de encontrar, sob o sentido absurdo da narrativa, um alto significado filosófico. Acrescente-se a isso o fato de que platônicos, como Numênio, possivelmente encontraram nesse mito uma alusão aos mistérios, 
incluindo-o ao longo da iniciação filosófica. Além disso, já havia um certo movimento de reconciliação entre Homero e Platão, que se encontrará cristalizado em Proclo, alguns séculos depois de Plotino, na medida em que tais tentativas de reconciliação tornamse especialmente relevantes diante da necessidade de proteger a religião grega da invasão cristã. Quais tenham sido os motivos de Plotino é de fato impossível decifrar, mas todas essas hipóteses mostram que havia um contexto no qual a grande falsidade já não mais precisava ser banida da filosofia. Pode-se dizer que havia mesmo, enfim, um contexto geral que legitimava, de bom grado, a presença da trilogia divina hesiódica no cerne do pensamento plotiniano. Portanto, ainda que não seja intencional, esse mito sugere que, no processo mesmo da interpretação, há ruptura e contrassenso. E parece ser disso que emerge a originalidade de um autor como Plotino. Com respeito à transposição filosófica desse mito, nota-se que o licopolitano recolhe diferentes aspectos dele, tanto originários de Hesíodo, como de Homero, explicitando, com eles, as hierarquias do mundo superior. $\mathrm{O}$ mito mostra como uma realidade emerge da outra, em um processo de continuidade, mas, simultaneamente, rompe com ela para se autoconstituir. Finalmente, na análise dessa genealogia, ressurgem aspectos do mito que já haviam sido aludidos, por exemplo, o tom retórico. Em um dado discurso, Plotino apela para a emoção do ouvinte, através da narrativa de uma história vivida - um personagem fictício anuncia o que viu - e, ao mesmo tempo, persuade o interlocutor da veracidade do mito. 
O sexto capítulo, figuras miticas, se articula em torno da definição do mito através de outras relações que não com o tempo. Este capítulo também é uma tentativa de olhar um pouco além dos estudos existentes acerca do mito em Plotino, na medida em que ele é centrado na noção de mito como imagem. E mais especificamente, como um tipo de imagem que tem relação com as imagens visuais. Com efeito, já foi sublinhado o aspecto no qual tais imagens se diferenciam: diante de uma pintura, por exemplo, é possível ter uma visão sinóptica, panorâmica, onde tudo se oferece juntamente e simultaneamente ao olhar, ao passo que os mitos, estas misteriosas figuras linguísticas e filosóficas, estão sujeitos à linearidade da linguagem, à sucessão das sílabas e das palavras e, quando são discursos, ao tempo da narrativa. Por consequência, ainda que uma linguagem figurativa, como a poesia ou a expressão alegórica, enseje mostrar o que está ausente, ela só pode fazer isso em uma ordem diacrônica. Este é o aspecto discursivo do mito, que se conecta à faculdade dianoética da alma, e que foi analisado no capítulo acerca dos discursos míticos genealógicos. Aqui trata-se de estudar o aspecto figurativo, que se conecta também à faculdade da imaginação. Portanto, notouse que as figuras míticas estabelecem uma relação de semelhança assimétrica com seu referente, na medida em que não o duplicam, mas sim aludem a ele. $\mathrm{Ou}$ seja, eles mostram algo, e, nesse sentido, eles são figuras que nutrem a faculdade da imaginação. Assim, pode-se dizer que eles têm uma vida própria, constituindo-se um fato psíquico, capaz de incitar o pen- 
samento discursivo a explicitá-las e, desse modo, a se explicitar através da palavra. Os mitos, então, têm um caráter alegórico, pois, enquanto imagens, eles parecem corresponder à expressão alegórica, mas entendidos como discursos, eles remetem à exegese alegórica. $\mathrm{E}$ aqui cabe notar que as noçóes de figura e discurso não se excluem: um discurso mítico é também figurativo; uma figura, mesmo apenas mencionada com valor de metáfora, participa da ordem do discurso. Ademais, como na alegoria, os mitos solicitam uma hermenêutica que lhes descubra o sentido oculto. É desse contexto que emerge a relação entre a exegese dos mitos e a dos discursos de Platão e Pitágoras, eles também enigmáticos. Por um lado, os mitos e a doxografia têm algo em comum: ambos são discursos, portanto oferecem um equivalente sensível da unidade. Além disso, tanto uns como outros estão abertos à interpretação. Mas exatamente sob tal aspecto reside uma diferença: os discursos dos filósofos estão sujeitos ao confronto e à crítica; os mitos, não. Eles jamais entram nos tratados para serem refutados, ou corrigidos, ou mesmo para superar outros discursos, como ocorre somente com os discursos de Platão. Finalmente, cabe notar que as figuras míticas semelham-se às imagens que eram mostradas nas religiōes de mistérios. Plotino estabelece um certo paralelismo entre a interpretação dos mitos e dos mistérios, que então passa a ser designada de mística. Nesse sentido, eles se inserem no processo de mudança do modo de vida a que se submete o iniciado. Mas aqui, novamente, é preciso ter cuidado em não considerar que os mitos constituam sozinhos 
o caminho completo de ascensão. Eles indicam, mostram, sinalizam, mas não se confundem com as práticas religiosas, nem mesmo parecem denotar quaisquer aspectos da religiosidade de Plotino.

No sétimo capítulo, Figuras da alma, analisam-se algumas figuras míticas, com base nas hipóteses avançadas até então. Primeiro foram escolhidas quatro figuras da Alma, sendo que três delas encontram-se no mesmo tratado, IV, 3 [27]: Dioniso, Prometeu e Pandora. Por isso foi feito um estudo da parte do tratado que se situa entre ambos os mitos. A outra figura, anônima, foi escolhida primeiramente devido a uma relação com Dioniso: ambos simbolizam aspectos da descida da alma. Dioniso concerne à alma do mundo, o anônimo às almas individuais que se deixam iludir por reflexos enganadores na matéria. Também no mito de Dioniso o espelho, ou melhor, a noção de imagem especular desempenha um papel fundamental, porquanto a descida da alma do mundo corresponde à visão do menino refletido no espelho. Assim, este capítulo desenvolve o tema da imagem e dos reflexos. Os mitos de Dioniso e do personagem anônimo foram analisados por Hadot e Pépin, respectivamente. Porém, o mito de Prometeu e Pandora parece não ter recebido ainda uma análise, motivo pelo qual, por um lado, com o presente estudo tenta-se mais uma vez ir um pouco adiante em relação aos comentários existentes sobre o mito em Plotino. Mas, por outro lado, a análise deste mito poderia ser aprofundada, tanto do ponto de vista das suas origens, como dos aspectos filosóficos nele envolvidos. É um mito complexo, que abrange o tema da descida 
das almas e da providência, complementares, portanto, não somente ao mito de Dioniso, mas também aos de Eros e Afrodite, motivo pelo qual o mito de Prometeu e Pandora foi enfim escolhido. Além disso, ele mobiliza várias outras figuras, como Epimeteu, Hefesto, Héracles, as Graças, Afrodite e Zeus.

O último capítulo, Zeus, figura polissêmica, retoma a emblemática figura de Zeus. Esta tampouco mereceu, da parte dos comentadores, a atenção devida, haja vista ser uma das figuras mais mencionadas nas Enéadas. É bem verdade que o mito da tríade divina despertou a atenção de alguns estudiosos, notadamente Hadot. Mas Zeus, fora do esquema genealógico, parece ter feito correr pouca tinta. Todavia essa figura polissêmica é extremamente interessante, pois comprova várias das hipóteses lançadas ao longo da pesquisa, como a da função persuasiva, a das figuras não-interpretadas, a da verificação, quando, por exemplo, Zeus é verificado com o demiurgo, que pode ser considerado uma figura mítica e, finalmente, a da função metafórica, com o estudo do Zeus de Fídias. Esta figura é bastante interessante também porque ela permite voltar à comparação entre mito e imagem visual, e à relação entre imaginação e pensamento discursivo. A propósito, cabe notar que esta pesquisa não esgota o estudo acerca das faculdades da Alma em Plotino. Pelo contrário, ele apenas apresenta passos possíveis para novas pesquisas. Um deles, que parece especialmente instigante, é aprofundar os estudos acerca da imaginação e das relações entre mito e imaginação, e também entre as imagens visuais e a imaginação. Tem-se ainda 
a sensação de que esta pesquisa tentou percorrer um vasto território, o do mito, sem esgotá-lo. Antes, ela deixou abertas várias outras questões, além das ora aludidas. Dentre tais possibilidades, pode-se mencionar o catálogo dos mitos nas Enéadas, inacabado, que se apresenta em apêndice. 


\section{BIBLIOGRAFIA}

\section{FONTES PRIMÁRIAS}

\subsection{TEXTO GREGO DAS ENÉADAS}

HENRY, P. \& SCHWYZER, H.-R (1951-1973). Plotini Opera, Museum Lessianum. Paris: Desclée de Brouwer; Bruxelles, L' Édition Universelle (Editio major), vv. I-III.

HENRY, P. \& SCHWYZER, H.-R (1964-1982). Plotini

Opera, Scriptorum classicorum Bibliotheca Oxoniensis. Oxford: Univ. Pr. (Editio minor), vv. I-III.

\subsection{TRADUÇÕES COMPLETAS DAS ENÉADAS}

[Armstrong] PLOTINUS (1988). Enneads. With an english translation by A. H. Armstrong. Loeb Classical Library. $1^{\text {a }}$ ed. 1966. Cambridge: Harvard Univ. Pr. \& London: Heinemann. 
[Bouillet] Les Ennéades de Plotin, chef de l'école néoplatonicienne (1981). Traduits par la première fois en français accompagnés de sommaires, de notes et d'éclaircissements et précédés de la Vie de Plotin, avec des fragments de Porphyre, de Simplicius, d'Olympiodore, de Saint Basile etc., par M.-N. Bouillet. Vols. I-III. Paris: 1857-1861. Reimpr. Frankfurt: Minerva, 1968. Paris: Vrin.

[Bréhier] PLOTIN (1989). Ennéades. Texte établi et traduit par E. Bréhier. vv. I -VI. 1ª ed. 1924. Paris: Les Belles Lettres.

[Cilento] PLOTINO (1973). Enneadi. Versione integra e commentario critico, 3 vol. $1^{\text {a }}$ ed. 19471949. Bari: Laterza.

[Faggin] PLOTINO (2000). Enneadi. Traduzione, introduzione, note e bibliografia di G. Faggin. Presentazione e iconografia plotiniana di G. Reale. $1^{a}$ ed. 1947-48. Milano: Bompiani.

[Harder] Plotins Schriften (1962-1971). Übersetzt von R. Harder. Neubearbeitung mit griechischem Lesetext und Anmerkungen Fortgeführt von R. Beutler und W. Theiler. Fünf Bände. Hamburg: Felix Meiner Verlag.

[Igal] PLOTINO (1982) I-II, (1988) V-VI, (1989) III-IV. Enéadas. Introducciones, traducciones y notas de J. Igal. vv. I-III. Madrid: Gredos.

[McKenna] PLOTINUS (1956). The Enneads. Translated by St. McKenna, revised by B. S. Page, preface by E. R. Doods, introduction by P. Henry. London: Faber and Faber. 


\subsection{TRADUÇÕES DE TRATADOS ISOLADOS E EDIÇÕES INCOMPLETAS}

BARACAT Jr., J. C. (2006). Plotino, Enéadas I, II e III; Porfírio, Vida de Plotino. Introdução, tradução e notas. $700 \mathrm{f}$. Tese (Doutorado em Letras) - Faculdade de Letras, Universidade Estadual de Campinas, Campinas.

JANKÉLÉVITCH, V. (1988). Plotin, “Ennéades” I, 3. Paris: Cerf.

PLOTIN (1991). Du Beau. (Ennéades I, 6; V, 8). Préface, traduction et commentaires de P. Mathias. Paris: Presses Pocket.

PLOTIN (1999). Ennéade III, 7 [45]. De l'éternité et $d u$ temps. Traduction et commentaire A. Pigler. Paris: Ellipses.

PLOTIN (1993). Les deux matières [Ennéade II, 4, (12)]. Introduction, texte grec, traduction et commentaire par J. -M. Narbonne. Paris: Vrin.

PLOTIN (1990). Traité sur la liberté et la volonté de l'Un. [Ennéade VI, 8 (39)]. Introduction, texte grec, traduction et commentaire par G. Leroux. Paris: Vrin.

PLOTIN (1980). Traité sur les nombres (Ennéade VI 6 [34]). Introduction, texte grec, traduction, commentaire et index grec par J. Bertier, L. Brisson et alli. Paris: Vrin.

PLOTIN (1987). Traité 38 (VI, 7). Introduction, traduction, commentaire et notes par P. Hadot. Paris: Cerf. 
PLOTIN (2000). Traité 49 (V, 3). Introduction, traduction, commentaire et notes par B. Ham. Paris: Cerf. PLOTIN (1990). Traité 50 (III, 5). Introduction, traduction, commentaire et notes par P. Hadot. Paris: Cerf.

PLOTIN (2004). Traité 53 (I, 1). Introduction, traduction, commentaire et notes par G. Aubry. Paris: Cerf. PLOTIN (2002). Traités1-6. Traduction sous la direction de L. Brisson et J.-F. Pradeau. Paris: Flammarion.

PLOTIN (2003). Traités 7-21. Traduction sous la direction de L. Brisson et J.-F. Pradeau. Paris: Flammarion.

PLOTIN (2004). Traités 22-26. Traduction sous la direction de L. Brisson et J.-F. Pradeau. Paris: Flammarion.

PLOTIN (2005). Traités 27-29. Traduction sous la direction de L. Brisson et J.-F. Pradeau. Paris: Flammarion.

PLOTIN (2006). Traités 30-37. Traduction sous la direction de L. Brisson et J.-F. Pradeau. Paris: Flammarion.

PLOTIN (2007). Traités 38-41. Traduction sous la direction de L. Brisson et J.-F. Pradeau. Paris: Flammarion.

PLOTINO (2007). Enéadas. Textos esenciales. Traducción, notas y estudio preliminar: M. I. Santa Cruz; M. I. Crespo. Buenos Aires: Colihue.

PLOTINO (1995a). Enneade III 7. In: BEIERWALTES, W. Eternità e Tempo. Saggio introduttivo, testo con 
traduzione e comentario. (Traduzione di A. Trotta). Milano: Vita e Pensiero.

PLOTINO (1995b). Enneade V 3. In: BEIERWALTES,

W. Autoconoscenza ed esperienza dell'Unità. Saggio introduttivo, testo con traduzione e commentario. (Traduzione di A. Trotta). Milano: Vita e Pensiero. PLOTINUS (1983). Ennead V. 1. On the three principal hypostases. A commentary with translation by $\mathrm{M}$. Atkinson. Oxford: University Press.

SOARES, L. G. E. C. (2003). "PLOTINO. Acerca da beleza inteligivel (Enéada V, 8 [31])”. Introdução, tradução e notas. Kriterion, 107, 110-135.

WOlTERS, A. M. (1972). Plotinus "On Eros". Acad. Proesfschirift, Uitg. Fil. Inst., V.U., Amsterdam.

\subsection{OUTROS AUTORES ANTIGOS}

ARISTÓFANES (1984). A paz. Introdução, versão do grego e notas de M. F. de Sousa e Silva. Coimbra: Instituto Nacional de Investigação Científica.

ARISTOTE (1993). De l'âme. Traduction et présentation par R. Bodéüs. Paris: Flammarion.

ARISTOTE (1967). Topiques. Texte établi et traduit par J. Brunschwig. Tome 1, livres I-IV. Paris: Les Belles Lettres.

ARISTÓTELES (1982). Metafísica. Ed. trilingue V. G. Yerba. 2 vols. Madrid: Gredos.

ARISTÓTELES (1990). Retórica. Introducción, traducción y notas por Q. Racionero. Madrid: Gredos.

AULU-GELLE (1967). Nuits Attiques. Texte établi et traduit par R. Marache. Tome 1, livres I-IV. Paris: Les Belles Lettres. 
BOTER, G (1999). The Encheiridion of Epictetus and its three Christian adaptations. Transmission and critical editions. Leiden: Brill.

BURY, R. G (1973). The Symposium of Plato. With introduction, critical notes and commentary by R. G. Bury. Cambridge: W. Heffer and Sons Ltd.. CICERO (s/d). De l'Orateur. Texte établi, traduit et annoté par F. Richard. Paris: Garnier.

CICERO (1999). Sobre la naturaleza de los dioses. Introducción, traducción y notas de A. Escobar. Madrid: Gredos.

Comicorum atticorum fragmenta (1880). Edidit T. Kock. 3 v. Lipsiae: Teubneri.

CORNUTO (2003). Compendio di Teologia Greca. A cura di I. Ramelli. Milano: Bompiani.

Die neuplatonische, fäschlich dem Galen zugeschriebene Schrift. Pròs Gaûron Gaûron perì tôu pōs empsykhoûntai tà émbrua (1895).)Aus der Pariser Handschrift zum ersten Male herausgegeben von K. Kalbfleisch. Berlin.

[DIELS-KRANZ] DIELS, H (1960-1961). Die Fragmente der Vorsokratiker: griechisch und deutsch.Berlin: Weidmannsche (Editada com aditamentos por W. KRANZ).

DIOGËNE LAËRCE (1999). Vie et doctrines des philosophes illustres. Traduction française sous la direction de M.O. Goulet-Cazé. Paris: LGF/Le Livre de Poche.

Fragmentos Órficos (2007). Organização e tradução G. G. Gazzinelli. Belo Horizonte: Editora UFMG. 
EPICTETO (1993). Disertaciones: por Arriano. Traducción, introducción y notas de P. O. García. Madrid: Gredos.

EURÍPIDES (1975). As Fenícias. Introdução, tradução e notas de M. S. Alves. Coimbra: Universidade de Coimbra.

ÉSQUILO (1993). Prometeu acorrentado. Tradução do grego, introdução e notas de M. G. Kury. Rio de Janeiro: Jorge Zahar.

ESTRABÓN (2001). Geografía. v. 4, livros VIII-X. Traducción y notas de J. J. T. Esbarranch. Madrid: Gredos.

HÉRACLITE (1989). Allégories d'Homère. Texte établi et traduit par F. Buffière. Paris: Les Belles Lettres.

HÉSIODE (1999). La Théogonie. Les Travaux et les Jours et d'autres poèmes. Traduction de P. Brunet. Commentaires de M.-C. Leclerc. Paris: LGF/ Le Livre de Poche.

HESÍODO (2002). Os Trabalhos e os Dias. $1^{\text {a }}$ parte. Tradução, introdução e comentário M. C. N. Lafer. São Paulo: Iluminuras.

HESÍODO (1995). Teogonia. A origem dos deuses. Estudo e tradução J. Torrano. $3^{a}$ ed., revisada e acrescida do original grego. São Paulo: Iluminuras.

HOMÈRE (1955). Iliade. Texte établi et traduit par P. Manzon. Tome I: chants I-VI; tome II: chants VII-XII. Paris: Les Belles Lettres.

HOMÉRE (1924). L'Odissée. Texte établi et traduit par P. Manzon. Tome I: chants I-VII; tome II: chants VIII-XV; tome III: chants XVI-XXIV. $1^{\mathrm{a}}$ ed. Paris: Les Belles Lettres. 
HOMERO (2002). Ilíada. 2 vols. Trad. de H. de Campos. Introdução e organização T. Vieira. São Paulo: Mandarim.

HOMERO (2007). Odisséia. Vv. I-III. Trad. de D. Schüler. Porto Alegre: L\&PM.

MARC-AURÈLE (1964). Pensées pour moi-même suivies du Manuel d'Épictete. Traduction, préface et notes par M. Meunier. Paris: Garnier.

NUMÉNIUS (1973). Fragments. Texte établi et traduit par. E. des Places. Paris: Les Belles Lettres.

OVIDE (1955). Les métamorphoses. Texte établi et traduit par G. Lafaye. Paris: Les Belles Lettres.

PAUSANIAS (1992). Description de la Grèce. Livre I: L’Attique. Texte établi par M. Casevitz. Traduit par J. Pouilloux et commenté par F. Chamoux. Paris: Les Belles Lettres.

PHOTIUS (1959-1991). Bibliothèque. Texte établi et traduit par R. Henry; index par J. Schamp. Vv. I-IX. Paris: Les Belles Lettres.

PLATÃO (2001). Crátilo. Introdução J. Trindade dos Santos. Tradução M. J. Figueiredo. Lisboa: Instituto Piaget.

PLATÃO (1997). Górgias. Introdução, tradução do grego e notas de M. O. Pulquerio. Lisboa: Edições 70. PLATÃO (2006). O Banquete. Tradução, introdução e notas de M. T. S. de Azevedo. Lisboa: Ed. 70. PLATÁO (2003). Parmênides. Texto estabelecido e anotado por J. Burnet; tradução, apresentação e notas de M. Iglésias e F. Rodrigues. Rio de Janeiro: Ed. PUC-Rio; São Paulo: Loyola. 
PLATÃO (1999). Protágoras. Tradução, introdução e notas de A. P. E Pinheiro. Lisboa: Relógio d'água. PLATÃO (2001). República. Introdução, tradução e notas de M. H. da Rocha. Lisboa: Fundação Calouste Gulbenkian.

PLATO (1929). Timaeus, Critias, Cleitophon, Menexenus, Epistles. v. XI. With an english translation by R. G. Bury. The Loeb Classical Library. Cambridge: Harvard.

PLATON (2000). Le Banquet. Traduction inédite, introduction et notes par L. Brisson. Paris: Flammarion.

PLATON (2006a). Les Lois. Livres I à VI. Traduction par L. Brisson et J.-F. Pradeau. Paris: Flammarion. PLATON (2006b). Les Lois. Livres VII à XII. Traduction par L. Brisson et J.-F. Pradeau. Paris: Flammarion. PLATON (1987). Lettres. Traduction inédite, introduction et notes par L. Brisson. Paris: Flammarion. PLATON (1935). Le Politique. Oeuvres complètes tome IX $-1^{\mathrm{e}}$ partie. Texte établi et traduit par A. Diès. Paris: Belles Lettres.

PLATON (1993). Le Sophiste. Traduction inédite, introduction et notes par N. Cordero. Paris: Flammarion. PLATON (1991). Phédon. Traduction nouvelle, introduction et notes par M. Dixsaut. Paris: Flammarion. PLATON (2000). Phèdre. Traduction inédite, introduction et notes par L. Brisson. Suivie de La pharmacie de Platon par J. Derrida. Paris: Flammarion. PLATON (1949). Philèbe. Oeuvres complétes, tome IX $-2^{\mathrm{e}}$ partie. Texte établi et traduit par A. Diès. Paris: Les Belles Lettres. 
PLATON (1969). Sophiste, Politique, Philèbe, Timée, Critias. Édition établie par É. Chambry. Paris: Flammarion.

PLATON (1992). Thééthète. Traduction inédite, introduction et notes par M. Narcy. Paris: Flammarion.

PLATON (1999). Timée, Critias. Présentation et traduction par L. Brisson. Paris: Flammarion.

PLINE, L'ANCIEN (1985). Histoire Naturelle. Livre XXXV. Texte établi, traduit et commenté par J.-M. Croisille. Paris: Les Belles Lettres.

PLUTARCO (1995). Isis y Osiris. Diálogos Píticos. Obras Morales y de Costumbres, v. VI. Introducciones, traducciones y notas por F. P. Pardo y J.A.F. Delgado. Madrid: Gredos.

PLUTARQUE (1972). Oeuvres morales. Introduction générale par R. Flacelière et J. Irigon; texte établi et traduit par A. Philippon et al. Paris: Les Belles Lettres.

PORFIRIO (1986). L'Antro delle Ninfe. Testo, traduzione, introduzione e note di L. di Simonini. Classici n. 48. Milano: Adelfi.

PORFIRIO (1992). La gruta de las ninfas. Carta a Marcela. Traducción M. P. Lorente. Madrid: Ediciones Clássicas.

PORPHYRE (2006). A Gauros. Sur la manière dont l'embryon reçoit l'âme. Appendice II. In: FESTUGIÈRE, A.-J. La Révélation d'Hermès Trismégiste. 3 vol. Paris: Les Belles Lettres, 265-305.

PORPHYRE (1982). La vie de Plotin. 1, Travaux préliminaires et index grec complet. 2, Études d'introduction, texte grec et traduction française, 
commentaire, notes complémentaires, bibliographie.

Par L. Brisson et al. Paris: Vrin.

PORPHYRII (1880). Quaestionum Homericarum ad Iliadem Pertinentium. Reliquiae. Ed. H. Schrader. Lipsiae.

Poetica pre-platonica. Testimonianze e frammenti (1963). Testo, traduzione e commento di G. Lanata. Firenze: La Nuova Italia Editrice.

Scholia Graeca in Homeri Iliadem (scholia vetera) (1969-1988). Recensuit H. Erbse. Berolini: de Gruyter.

Scholia in Homeri Odysseae (1966). Ed. A. Ludwich; praefatiunculam lingua vernacula scriptam adiecit H. Erbse. Königsberg 1888-1890. Hildesheim: Georg Olms.

SCARPI, P. (a cura di) (2004). Le religioni dei misteri. $V$. I: Eleusi, Dionisismo, Orfismo. Milano: Fondazione Lorenzo Valla; Arnoldo Mondadori Editore. TIMAEUS LOCRUS (1972). De Natura Mundi et Animae. Überlieferung, Testimonia, Text und Übersetzung von W. Marg. Editio Maior. Leiden: Brill.

\section{FONTES SECUNDÁRIAS}

ARMSTRONG, A. H. (1940). The archicteture of the intelligible universe in the philosophy of Plotinus. Cambridge: Classical Studies.

ARNOU, R. (1967). Le désir de Dieu dans la philosophie de Plotin. $1^{\text {a }}$ ed. 1921. Roma: Gregoriana. 
ARNOU, R. (1921). Prâxis et Theōría. Étude de détail sur le vocabulaire et la pensée des Ennéades de Plotin. Paris: Félix Alcan.

AUBENQUE, P. (2005). "Narcisse ou Hylas? Une contribution de Goethe à l'exégèse de Plotin". In: VEGLERIS, E. (Ed.) Cosmos et psychè, Mélanges offerts à Jean FREREE. Hildeheim: Olms, 265-269.

BASTOS, F. (2003). A Teogonia de Ferécides de Siro. Lisboa: Imprensa Nacional/Casa da Moeda.

BAZÁN, F. G. (1973). "Plotino y el lenguaje de la metafísica". Cuadernos de Filosofia, 13, 91-110.

BEIERWALTES, W. (1981). "Image and counterimage". In: BLUMENTHAL, H. J., MARKUS, R. A. Neoplatonism and early Christian Thought. London: Variorum, 236-247.

BELAYCHE, N. (s/d). "Les langages de l'expérience mystique chez Plotin". Cahiers d'Anthropologie Religieuse -3. École doctorale d'histoire des religions. Presses Universitaires de Paris-Sorbonne, 9-50.

BERGSON, H. (2005). Cursos sobre a filosofia grega: São Paulo, Martins Fontes.

BERTI, E. (1997). "L'oggetto dell' eikòs mythos nel Timeo di Platone". In: CALVO, T. and BRISSON, L. (1997). Interpreting the Timaeus - Critias. Proceedings of the IV Symposium Platonicum. Volume 9 of International Plato Studies. Academia Verlag, 119-131.

BLUMENTHAL, H. J. (1971). Plotinus' psychology: His doctrines of the embodied soul. La Haie: Martinus Nijhoff. 
BOLLACK, J. (1997). La Grèce en personne. Les mots sous le mythe. Paris: Seuil.

BOYS-STONES, G. R. (Ed.) (2003). Metaphor, Allegory and the Classical Tradition. Ancient Thought and Modern Revisions. Oxford: O.U.P. BRANDÄO, B. G. S. L. (2007). Experiência Mistica e Filosofia em Plotino. 146 f. Dissertação (Mestrado em Filosofia) - Faculdade de Filosofia, Universidade Federal de Minas Gerais, Belo Horizonte.

BRÉHIER, E. (1955). Études de Philosophie Antique. Paris: PUF.

BRISSON, L. (1991). "De quelle façon Plotin interprète-t-il les cinq genres du Sophiste? (Ennéades VI, 2 [43] 8)”. In: AUBENQUE, P. (Dir.). Études sur le Sophiste de Platon. Napoli: Bibliopolis, 449-473.

BRISSON, L. (1996). Introduction à la philosophie du mythe 1 - Sauver les mythes. Paris: Vrin.

BRISSON, L. (2004). "L'allégorie comme interprétation des mythes, de l'Antiquité à la Renaissance”. In: PEREZ-JEAN, B.; EICHEK-LOJKINE, P. (études réunies par). L'allégorie de l'Antiquité à la Renaissance. Paris: Honoré Champion.

BRISSON, L. (2003). Leituras de Platão. Porto Alegre: Edipucrs.

BRISSON, L. (2006). "La place de la mémoire dans la psychologie plotinienne". In: PRADEAU, J.-F. (Resp.). Etudes Platoniciennes III. L'Âme amphibie. Études sur l'âme selon Plotin. Paris: Les Belles Lettres, 13- 27. 
BRISSON, L. (1999). "Logos et logoi chez Plotin. Leur nature et leur rôle". Les Cahiers Philosophiques de Strasbourg, 8, 87-108.

BRISSON, L. (1995). Orphée et l'Orphisme dans l'Antiquité gréco-romaine. Variorum collected studies series.

BRISSON, L. (2005). "Peut-on parler d'union mystique chez Plotin?" In: DIERKENS, A. et RYKE, B. B. Mystique: la passion de l'Un, de l'Antiquité à nos jours. Éditions de l'Université de Bruxelles, tome XV, 61-72.

BRISSON, L. (1994). Platon, les mots et les mythes. Comment et pourquoi Platon nomma les mythes? Paris: Ed. La Découverte.

BRUNNER, F. (1973). "Le premier traité de la cinquième Ennéade. Des trois hypostases principielles". Revue de Théologie et de philosophie, 23, 2, 135-172.

BUFFIERE, F. (1956). Les Mythes d'Homère et la pensée grecque. Paris: Les Belles Lettres.

BURKERT, W. (2003). Les cultes à mystères dans l'Antiquité. Paris: Les Belles Lettres.

BURKERT, W. (2001). Mito e mitologia. Lisboa: Ediçôes 70.

CHARBONEAUX, J. (1943). La sculpture grecque classique. Paris: Éditions de Cluny/ Fernand Nathan éditeur.

CHARRUE, J.M. (1993). Plotin, lecteur de Platon. Paris: Belles Lettres.

CHIRON, P. (2004). "Allégorie et langage". In: PEREZ-JEAN, B. et EICHEK-LOJKINE, P. 
(études réunies par) L'allégorie de l'Antiquité à la Renaissance. Paris: Honoré Champion, 41-73.

CHRÉTIEN, J.-L. (1989). "L'analogie selon Plotin”. Les études philosophiques, 3-41, 305-318.

CILENTO, V. (1960). "Mito e poesia nelle Enneadi di Plotino". In: Les Sources de Plotin. Entretiens sur l'Antiquité Classique. Vol. V. VendoeuvresGenève: Fondation Hardt, 243-323.

COLLETTE, B. (2002). Dialectique et hénologie chez Plotin. Bruxelles: Ousia.

COLLETTE, B. (2003). “'Lâme ne pense jamais sans phantasma'. Lecture plotinienne de la noétique d'Aristote". Revue de philosophie ancienne, 2, 21, 115-135.

COMTE-SPONVILLE, A. (2000). O Ser-Tempo. São Paulo: Martins Fontes, 2000.

COULOUBARITSIS, L. (2000). Aux origines de la philosophie européenne. De la pensée archä̈que au néoplatonisme. Bruxelles: Éditions De Boeck Université.

COULOUBARITSIS, L. (1990a). "De la généalogie à la genèséologie”. In: MATTÉI, J.-F. (Dir.). La naissance de la raison en Grèce. Paris: PUF, 83-96.

COULOUBARITSIS, L. (2006). "Fécondité des pratiques catalogiques”. Kernos, 19, 249-266. COULOUBARISTIS, L. (1990b). "La logique du mythe et la question du non-être". Revue de théologie et de philosophie, 122, 323-340.

COULOUBARITSIS, L. (2005). "La philosophie à l'épreuve du mythe et de la littérature". (Con- 
férence en 19/10/2005, à l'occasion du Prix de la Candidature en Philosophie et Lettres, Facultés Universitaires St. Louis, Bruxelles). COULOUBARITSIS, L. (1992). "Le logos hénologique chez Plotin". In: GOULET-CAZÉ, M. O. et al. (Dir.). Sophiếs maiêtores: Chercheurs de Sagesse. Hommage à Jean Pépin. Paris: Institut d'Études augustiniennes, 231-243.

COULOUBARITSIS, L. (1997). "Le temps hénologique". In: COULOUBARITSIS, L.; WUNENBURGER, J.J. (Dir.). Les figures $d u$ temps. Strasbourg: PUS, p. 89-107.

COULOUBARITSIS, L. (1986). Mythe et philosophie chez Parménide. Bruxelles: Ousia.

COULOUBARISTIS, L. (1988). "Mythe et religion. Une alliance de raison". Kernos, 1, 111-120.

DE KEYSER, E. (1955). De la signification de l'art dans les Ennéades de Plotin. Louvain: Publications Universitaires de Louvain.

DÉTIENNE, M. (1988). Dionysos à ciel ouvert. Paris: Hachette.

DÉTIENNE, M. (1977). Dionysos mis à mort. Paris: Gallimard.

DILLON, J. (1969). “Enn. III, 5: Plotinus' exegesis of the symposium myth" Agon, 3, 24-44.

DIXSAUT, M. (2006). "La rationalité projetée à l'origine". In: MATTÉI, J.-F. (Dir.). La naissance de la raison en Grèce. Paris: PUF, 59-75.

DIXSAUT, M. (2003). Platon. Paris: Vrin.

DODDS, E. R. (1960). "Numénius et Ammonius". In: Les Sources de Plotin. Entretiens sur l'Antiquité 
Classique. Vol. V. Vendoeuvres-Genève: Fondation Hardt, 1-61.

ECO, U. (2001). A busca da língua perfeita na cultura européia. Bauru: EDUSC.

ÉON, A. (1970). "La notion plotinienne d'exégèse". Revue internationale de philosophie, 92, 252-289.

FATAL, M. (1998). Logos et image chez Plotin. Paris: L'Harmattan.

FERWERDA, R. (1965). La signification des images et des métaphores dans la pensée de Plotin. Gröningen: J. B. Wolters.

FERWERDA, R. (1990). "Plotinus and the Muses". Hermes, 118, 2, 204-212.

FOUCART, P. (1999). Les mystères d'Eleusis. Paris: Pardès (reimpressão da $1^{\circ}$ ed. de 1914).

FRUTIGER, P. (1930). Les mythes de Platon. Etude philosophique et littéraire. Paris: Felix Alcan.

GALPÉRINE, M.C. (1996). Lecture du Banquet de Platon. Paris: Verdier.

GOULET, R. (2005). "La méthode allégorique chez les stoïciens”. In: ROMEYER DHERBEY, G. (Dir.) GOURINAT, J.-B. (Ed.). Les Stoüciens. Paris: Vrin.

GOULET-CAZÉ, M. O. (Dir.) (2000). Le commentaire: entre tradition et innovation. Actes du Colloque International de l'Institut des Traditions Textuelles. (Paris et Villejuif, 22-25 septembre 1999). Paris: Vrin.

GRABAR, A. (1945). "Plotin et les origines de l'esthétique médiévale”. Cahiers Archéologiques, I, 15-34.

GUITTON, J. (1959). Le temps et l'éternité chez Plotin et Saint Augustin. Paris: Vrin. 
HADOT, I. (2005). Arts libéraux et philosophie dans la pensée antique. Contribution à l'histoire de l'éducation et de la culture dans l'Antiquité. Paris: Vrin.

HADOT, P. (1998). Études de philosophie ancienne. Paris: Belles Lettres.

HADOT, P. (1981a). "Images mythiques et thèmes mystiques dans un passage de Plotin (V, 8, 10-13)". Néoplatonisme, Mélanges offerts à J. Trouillard. Les Cahiers de Fontenay, 19, 20, 21, 22, 205-214.

HADOT, P. (1981-1982). "La figure d'Eros dans l'oeuvre de Plotin”. Résumés des Conférences et Travaux. Annuaire de l'École Pratique des Hautes Etudes. Veme section: Sciences Religieuses, 90, 310-312.

HADOT, P. (1982-1983). "La figure d'Eros dans l'oeuvre de Plotin". Résumés des Conférences et Travaux. Annuaire de l'École Pratique des Hautes Études. $V^{\text {eme }}$ section: Sciences Religieuses, 91, 345-350.

HADOT, P. (1976). "Le mythe de Narcisse et son interprétation par Plotin". Nouvelle Revue de Psychanalyse, 13, 81-108.

HADOT, P. (2004). Le voile d'Isis. Essai sur l'histoire de l'idée de Nature. Paris: Gallimard.

HADOT, P. (1999a). O que é filosofia antiga? São Paulo: Loyola.

HADOT, P. (1981b). "Ouranos, Kronos and Zeus in Plotinus' treatise against the gnostics". In: BLUMENTHAL \& MARKUS. Neoplatonism and early Christian Thought. Essays in honour of A.H. Armstrong. London: Variorum Publ., 124-137. 
HADOT, P. (1983). "Physique et poésie dans le Timée de Platon”. Revue de Théologie et Philosophie, 115, 113-133.

HADOT, P. (1987). “Théologie, exégèse, révélation, écriture, dans la philosophie grecque". In: TARDIEU, M. (Éd.) Les règles de l'interprétation. Paris: Cerf, 13-34.

HADOT, P. (1999b). Plotin, Porphyre. Études néoplatoniciennes. Paris: Les Belles Lettres.

HARRINGTON, K. W. (1975). "Plotinus' allegorical approach to Platonic myth in Ennead III. 5 and its antecedents". Diotima, 3, 115-125.

HEISER, J. H. (1990). Logos and language in the philosophy of Plotinus. Variorum: The Edwin Mellen Press, 1990.

HOFFMANN, P. (1997). "L'expression de l'indicible dans le néoplatonisme grec de Plotin à Damascius”. In : LÉVY, C. et PERNOT, L. (textes réunis par). Dire l'évidence. Philosophie et Rhétorique Antiques. Paris: Harmattan, 335-390.

HOLLINSHEAD, M. B. (1999). "Adyton, opisthodomos and the inner room of the Greek temple". Hesperia, 68, 2, 189-218.

KAHN, C. H. (1979). The art and Thought of Heraclitus. An edition of the fragments with translation and commentary. Cambridge: Cambridge University Press.

KERÉNY, C. (2002). Dioniso. Imagem arquetipica da vida indestrutivel. São Paulo: Odysseus.

KUISMA, O. (2003). Art or experience. A study on Plotinus'Aesthetics. Helsinki: Societas Scientiarium Fennica. 
LACROSSE, J. (1994). L'amour chez Plotin. Érôs hénologique, érôs noétique, érôs psychique. Bruxelles: Ousia.

LACROSSE, J. (2005). "La pratique du mythe chez Plotin et Porphyre". (Colloque La Pensée Mythique. Créativité et Pratique. 6 à 12 octobre 2005, Université Libre de Bruxelles, Belgique).

LACROSSE, J .(2003a). La philosophie de Plotin. Intellect et discursivité. Paris: PUF.

LACROSSE, J. (1997). "Chronos psychique, aiôn noétique et kairós hénologique chez Plotin”. In: COULOUBARITSIS, L.; WUNENBURGER, J.J. (Dir.) Les figures du temps. Strasbourg: PUS, 75-87. LACROSSE, J. (1995). "L'exégèse du mythe de la naissance d'Eros (Banquet, 203 b-c) dans les Ennéades de Plotin". Les Cahiers Philosophiques de Strasbourg, 3, 131-147.

LACROSSE, J. (2003). “Temps et mythe chez Plotin”. Revue philosophique de Louvain, 2, 265-281.

LAMBERTON, R. (1986). Homer the theologian. Neoplatonist allegorical reading and the growth of the epic tradition. Berkeley, Los Angeles, London: University of California Press.

LASSEGUE, M. (1982). "Le temps, image de l'éternité chez Plotin". Revue philosophique de la France et de l'Étranger, 172, 405-418.

LAURENT, J. (1993). "Lecture et parole selon Plotin”. In: BESNIER, B. (Dir.). Scepticisme et exégèse. Hommage à Camille Pernot. École Normale Supérieure de Fontenay/Saint-Cloud, 185-194. 
LAURENT, J. (1999). L'homme et le monde selon Plotin. Fontenay-aux-Roses: ENS éditions.

LAWRENCE, A. W. (1998). Arquitetura Grega. São Paulo: Cosac \& Naify.

LECHAT, H. (189-). Phidias et la sculpture grecque au Veme siècle. Paris: Librairie de l'art ancien et moderne.

LEROUX, G. (1974). "Logique et dialectique chez Plotin: Ennéade I. 3 (20)”. Phoenix, 28, 180-192.

LOMBARDO, G. (2011). L'esthétique antique. Paris: Klincksieck.

LOUIS, P. (1945). Les métaphores de Platon. Rennes: Imprimeries Réunies,.

MARQUES, M. P. (1994). "Mito e filosofia". In: MARQUES, M. P et al. Mito. Série Cadernos de Texto, $\mathrm{n}^{\circ}$ 2. Belo Horizonte: Núcleo de Filosofia Sônia Viegas, 19-37.

MONTET, D. (1996). Archéologie et généalogie. Plotin et la théorie platonicienne des genres. Grenoble: Jérôme Millon.

MOUTSOPOULOS, E. (2000). Le problème de l'imaginaire chez Plotin. Paris: Vrin.

OLIVEIRA, L. (2005). "O belo em Plotino: do múltiplo ao Uno”. Sintese, 32, 259-274.

OLIVEIRA, L. (2007). "Uma sinfonia de autoridades: notas sobre a exegese dos antigos - Plotino, Enéada V, 1 [10], 8-9”. Kriterion, 116, 467-479.

O’ MEARA, D. (1990). "Le problème du discours sur l'indicible chez Plotin". Revue de théologie et de philosophie, 122, 145-156. 
O'MEARA, D. (1992). Plotin. Une introduction aux Ennéades. Paris: Cerf; Fribourg: Presses Universitaires de Fribourg.

O’MEARA, D. (1992). "Vie politique et divinisation dans la philosophie néoplatonicienne". In: GOULET-CAZÉ, M. O. et al. (Dir.). Sophiếs maiêtores: Chercheurs de Sagesse. Hommage à Jean Pépin. Paris: Institut d'Études augustiniennes, 501-510.

OTTO, W. F. (1965). Dyonisos: Myth and cult. Indiana and London: Bloomington.

PANOFSKY, E. (1994). Idea. A evolução do conceito de Belo. Contribuição à história do conceito da antiga teoria da arte. São Paulo: Martins Fontes.

PEDLEY, J. G. (1999). Art et archéologie de la Grèce. Cologne: Könemann.

PÉPIN, J. (1971). "Héraclès et son reflet dans le néoplatonisme”. In: Le Néoplatonisme. Colloques internationaux du CNRS. Royaumont, 9-13 juin 1969. Paris: Ed. du CNRS, 167- 192.

PÉPIN, J. (1987). La tradition de l'allégorie. De Philon d'Alexandrie à Dante. Paris: Études Augustiniennes. PÉPIN, J. (1962). "Le temps et le mythe". Les études philosophiques (37), 55-68.

PÉPIN, J. (1982). "Linguistique et théologie dans la tradition platonicienne". Langages, 65.

PÉPIN, J. (1976). Mythe et allégorie. Les origines grecques et les contestations judéo-chrétiennes. Nouvelle édition revue et augmentée. Paris: Études augustiniennes. 
PÉPIN, J. (1970). "Plotin et le miroir de Dionysos (Enn. IV, 3, [27], 12, 1-2) ". Revue Internationale de Philosophie, 92, 2, 304-320.

PÉPIN, J. (1955). "Plotin et les mythes". Revue philosophique de Louvain, 53, 5-27.

PÉPIN, J. (1982). "L'épisode du portrait de Plotin". In: PORPHYRE. La vie de Plotin. 1, Travaux préliminaires et index grec complet. 2, Études d'introduction, texte grec et traduction française, commentaire, notes complémentaires, bibliographie. Par L. Brisson et al. Paris: Vrin, 301-330.

PEREZ-JEAN, B., EICHEK-LOJKINE, P. (2004). (études réunies par). L'allégorie de l'Antiquité à la Renaissance. Paris: Honoré Champion.

PERNOT, L. (2000). La rhétorique dans l'Antiquité. Paris: LGF/Le Livre de Poche.

PIGLER, A. (1996). "Plotin exégète de Platon? La question du temps". Revue philosophique de la France et de l'Étranger, 186, 107-117.

PIGLER, A. (2002). Plotin: une métaphysique de l'amour. L'amour comme structure du monde intelligible. Paris: Vrin.

PRADEAU, J.-F. (2003). Limitation du principe. Plotin et la participation. Paris: Vrin.

RAVAISSON, F. (1963). Essai sur la Métaphysique d'Aristote. v. II. 2 Nachdr. der Ausg. Paris: 1837 und 1846. Hildesheim: Olms.

RIEDWEG, C. (1987). Mysterienterminologie bei Platon, Philon und Klemens von Alexandrien. Berlin, New York: Walter de Gruyter. 
ROUX, S. (2004). La recherche du principe chez Platon, Aristote et Plotin. Paris: Vrin.

SANTA CRUZ, M. I. (1993). "Filosofia y dialéctica en Plotino". Cuadernos de Filosofía, 39, 5-21.

SANTA CRUZ, M. I. (1997a). "Le discours de la Physique: eikòs lógos". In: CALVO, T. and BRISSON, L. Interpreting the Timaeus - Critias. Proceedings of the IV Symposium Platonicum. Volume 9 of International Plato Studies. Academia Verlag, 133-139.

SANTA CRUZ, M. I. (1997b). "Plotin lecteur de Platon. L'interprétation plotinienne (Ennéade VI 8, 18) d'un passage du Politique de Platon (284 e 6-7)". Cahier du centre d'études sur la pensée antique "kairòs kaì lógos", 7, 1-32.

SÉCHAN, L. (1960). El mito de Prometeo. Buenos Aires: Eudeba.

SCHIBLI, H. S. (1990). Pherekydes of Syros. Oxford: Clarendon Press.

SCHNIEWIND, A. (2003). L'éthique du sage chez Plotin. Le paradigme du spoudaios. Paris: Vrin.

SCHROEDER, F. M. (1996). "Plotinus and language”. In: GERSON, L. P. (Ed.), The Cambridge Companion to Plotinus. Cambridge: Cambridge University Press, 336-355.

SCHROEDER, F. M. (2002) "The Platonic text as Oracle in Plotinus". In: KOBUSCH, T., ERLER, M. (Org.). Metaphysik und Religion. Zur Signatur des spätantiken Denkens. München, Leipzig: K. G. Saur, 23-37. 
SCHÜLER, D. (2001). Eros: dialética e retórica. São Paulo: Edusp.

SCHWYZER, H.-R. (1960). "Bewubt und unbewubt bei Plotin”. In: Les Sources de Plotin. Entretiens sur l'Antiquité Classique. Vol. V. VendoeuvresGenève: Fondation Hardt, 343-378.

SOREL, R. (1998). "De l'interprétation du mythe". In: JACOB, A. (Dir). Encyclopédie Philosophique Universelle. Vol. IV - Le discours philosophique. Volume dirigé par J.-F. Mattéi. Paris: PUF, 1498-1513.

STRUCK, P. T. (1995). "Allegory, aenigma, and antimimesis: a struggle against Aristotelian rhetorical literary theory". In: ABBENES, J.G.J.; SLINGS, S.R.; SLUITER, I. (Eds.). Greek literary theory after Aristotle. A collection of papers in honour of D. M. Schenkeveld. Amsterdam: V.U. University Press, 215-234.

TARKOVSKI, A. (2010). Esculpir o tempo. Trad. J. L. Camargo. São Paulo: Martins Fontes.

TATE, J. (1934). "On the history of allegorism”. The Classical Quarterly, 2, 105-114.

TATE, J. (1929). "Plato and allegorical interpretation". The Classical Quarterly, 23, 142-154.

TATE, J. (1930). "Plato and allegorical interpretation". The Classical Quarterly, 24, 1-10.

TATE, J. (1927). "The beginnings of greek allegory”. Classical Review, XLI, 6, 214-215.

TROTTA, A. (1992). "Interpretazione e critica di Plotino della concezione del tempo dei suoi predecessori”. Rivista di Filosofia neo-scolastica, 2-3, 340-368. 
TROTTA, A. (1997). Il problema del tempo in Plotino. Milano: Vita e Pensiero.

TURLOT, F (1985). “Le 'logos' chez Plotin”. Les études philosophiques, 4, 517-528.

TROUILLARD, J. (1955). La purification plotinienne. Paris: PUF.

UCCIANI, L. (1998). Sur Plotin: la gnose et l'amour. Paris: Kimé.

UllMANN, R. A. (2002). Plotino - um estudo das Enéadas. Porto Alegre: Edipucrs.

VERNANT, J.-P. (1990). Mythe et religion en Grèce Ancienne. Paris: Seuil.

VERNANT, J. P. (2002). Mito e pensamento entre os gregos. São Paulo: Paz e Terra.

VERNANT, J.-P. (1989). L'individu, la mort, l'amour. Paris: Gallimard.

VERNANT, J.-P. (1999). L'univers, les dieux, les hommes. Récits grecs des origines. Paris: Seuil.

VERRA, V. (1992). Dialettica e filosofia in Plotino. Milano: Vita e Pensiero.

WALLIS, R. T. (1995). Neoplatonism. London: Gerald Duckworth \& Co..

WARREN, E.W. (1965). "Memory in Plotinus". Classical Quarterly, 15, 2, 252-260.

WHITMAN, J. (Ed.) (2000). Interpretation and allegory. Antiquity to the modern period. Leiden: Brill.

WUNENBURGER, J.-J. (1997). Philosophie des images. Paris: PUF.

ZAMORA, J. M. (2000). La génesis de lo múltiple. Materia y mundo sensible en Plotino. Valladolid: Universidad de Valladolid. 


\section{LÉXICOS E DICIONÁRIOS}

ALMEIDA PRADO, A. L. (2006). "Normas para a transliteração de termos e textos em grego antigo". Classica, 19.2, 298-299.

BAILLY, A. (1963). Dictionnaire Grec-Français. Paris: Hachette.

Brill's New Pauly: encyclopaedia of the ancient world. (2002) Edited by H. Cancik and H. Schneider; English edition, managing editor, C. F. Salazar, assistant editor, D. E. Orton. V. 1-7. Leiden; Boston: Brill.

CHANTRAINE, P. (1984). Dictionnaire étimologique de la langue grecque. Histoire des mots. Paris: Klincksiek ( $1^{\text {a }}$ ediçãa 1968$)$.

GRIMAL, P. (2005). Dicionário da mitologia grega e romana. Rio de Janeiro: Bertrand Brasil.

LIDDEL, H. G.; SCOTT, R. (1966). A greek-english lexicon. New ed. rev. and aug. by H. Stuart Jones, with the assistance of R. McKenzie. Oxford: The Clarendon.

MONTANARI, F. (2004). Vocabolario della lingua greca. Torino: Loescher.

PLACES, E. DES (1970). Lexique de la langue philosophique et religieuse de Platon. In: PLATON, Oeuvres Complètes. Tomes XIV, 2 vols. Paris: Les Belles Lettres.

RADICE, R. (Ed.) (2003). Lexicon. Vol. I Plato. Electronic edition by R. Bombacigno. Milano: Biblia. 
RADICE, R. (Ed.). Lexicon. Vol. II Plotinus. Electronic edition by R. Bombacigno. Milano: Biblia, 2004. SLEEMAN, J. H. \& POLLET, G. (1980). Lexicon Plotinianum. Leiden: Brill.

UREÑA PRIETO, M. H. T. et al (1995). Indice de nomes próprios gregos e latinos. Lisboa: Calouste Gulbenkian. 


\section{APÊNDICE}

\section{CATÁLOGO SIMPLIFICADO DOS MITOS DAS ENÉADAS}

\section{A) FIGURAS LIGADAS DIRETAMENTE À GENEALOGIA DE EROS}

Afrodite (Aphroditê)

32 ocorrências do nome, sendo a grande maioria no tratado III, 5 [50]

Outras se encontram nos tratados II, 3 [52]; IV, 3 [27]; V, 8 [31]; VI, 9 [9]

Eros (Érōs)

27 ocorrências, nem todas como deus, mas também como daimōn. A maioria em III, 5 [50]. Também em VI, 9 [9]

Penía (Penía)

28 ocorrências, sendo a maioria em III, 5 [50], mas também em I, 4 [46]; I, 8 [51]; II, 3 [52]; II, 4 [12]; II, 9 [33]; III, 1 [3]; III, 2 [47] 
Poros (Póros)

12 ocorrências, sendo a maioria em III, 5 [50] e uma em III, 6 [26] 14, 15

B) TRILOGIA DIVINA

Urano (Ouranós)

III, 5 [50] 2, 15

Cronos (Krónos)

II, 3 [52] 12, 22

III, 5 [50] 2, 29; 2, 33

$\mathrm{V}, 1[10] 4,9 ; 7,33$

Zeus (Zeús)

32 ocorrências, sendo a maioria no tratado III, 5 [50].

Além dessas,

I, 4 [46] 7, 24

II, 3 [52] 12, 20; 13, 30

III, 1 [3] 7, 20

III, 2 [47] 3, 16

IV, 3 [27] 12, 8

IV, 4 [28] 6, 8

V, 1 [10] 7, $34-36$

$\mathrm{V}, 3$ [49] 7, 13

V, 8 [31] 1, 39-40; 10, 1; 12, 8

VI, 9 [9] 7, 24

C) FIGURAS DIVERSAS

Adrastea (Adrásteia)

III, 2 [47] 13, 17 


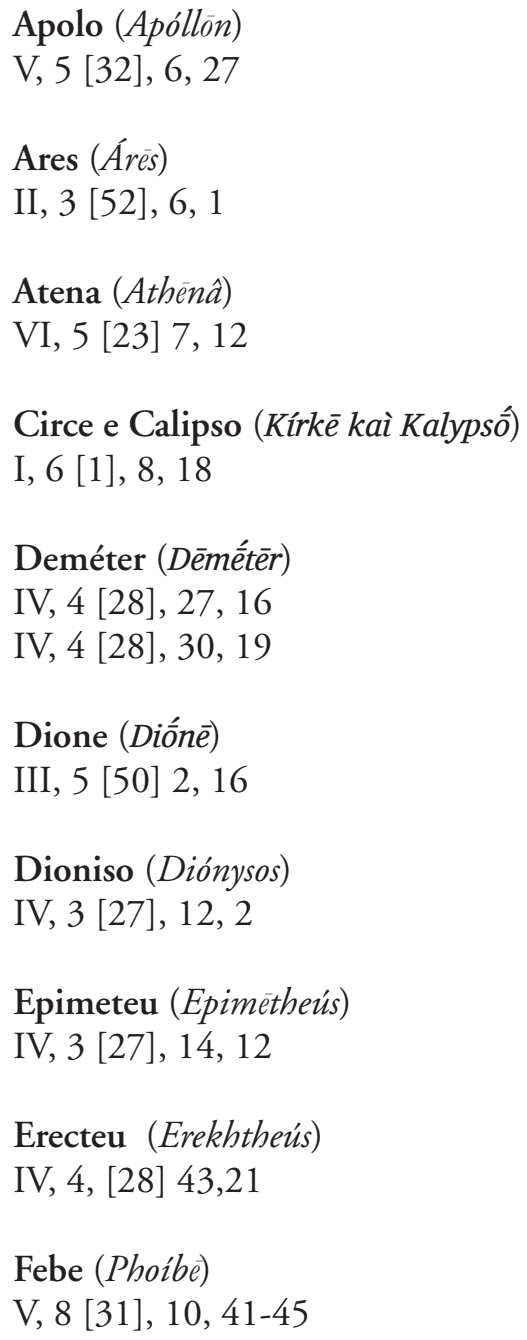


Glauco (Glaûkos)

I, 1 [53], 12, 14

Graças (Kháris)

IV, 3 [27] 14, 9

V, 8 [31], 1, 7-13

Hades (Háidēs)

I, 6 [1] 6, 4; 8, 15-21

I, 1 [53] 24, 4, 33

I, 7 [54] 3, 13

I, 8 [51] 13, 25

II, 9 [16] 6, 13

III, 4 [15] 6, 11

IV, 3 [27] 27, 7

VI, 4 [28] 16, 37

Hefesto (Héphaistos)

III, 2 [47] 14, 27

Helena (Elénê)

III, 3 [48] 5, 42

Hera (Héras)

III, 5 [50] 8, 22

Héracles (Heraklês)

I, 1 [53], 12, 32

IV, 3 [27], 14, 16.

IV, 3 [27], 27, 7

IV, 3 [27], 27, 13

IV, 3 [27], 32, 24-27 


$$
\begin{aligned}
& \text { Hermes (Hermês) } \\
& \text { II, } 3 \text { [52], 12, } 23 \\
& \text { III, } 6 \text { [26], 19, } 26
\end{aligned}
$$

Héstia (Estía)

IV, 4, [28] 27, 16; 30, 19

Idomeneu (Idomeneús)

III, 3 [48] 5, 43

Lete (Léthē)

IV, 3 [27] 26, 55

Linceo (Lygkeús)

$\mathrm{V}, 8$ [31], 4, 25

Lino (Linos)

III, 2 [14], 17, 67

Métis (Mêtis)

III, 5 [50], 5, 3

Minos (Minōs)

VI, 9 [9], 7, 23

Moira (Moîra) (Atropos e Laquesis são citadas)

II, 3 [52], 9, 2; 15, 10

Musas (Mồsa)

III, 7 [45] 11, 8

$\mathrm{V}, 8[31] 1,10$

$\mathrm{V}, 8[31] 10,42$ 


$$
\begin{aligned}
& \text { (não é nomeado) } \\
& \text { I, } 6 \text { [1] 8, 15-21 } \\
& \text { V, } 8 \text { [32] 2, 32-37 } \\
& \text { Odisseu (Odysseús) } \\
& \text { I, } 6 \text { [1] 8, } 18 \\
& \text { Páris (Párin) } \\
& \text { III, } 3 \text { [48] 5, } 42 \\
& \text { Príamo (Príamos) } \\
& \text { I, } 4 \text { [46] 5, } 7 \\
& \text { Prometeu (Promētheús) } \\
& \text { IV, } 3 \text { [27], 14, } 6 \\
& \text { Psiquê (Psyché) } \\
& \text { VI, } 9 \text { [9], } 9 \\
& \text { Rea (Réa) } \\
& \text { V, } 1 \text { [10], 7, 32 } \\
& \text { Tártaro (Tártaros) } \\
& \text { III, } 2 \text { [14] 17, 66 } \\
& \text { Tersites (Tersitēs) } \\
& \text { III, } 2 \text { [47], 3, 18 }
\end{aligned}
$$


(Página deixada propositadamente em branco) 


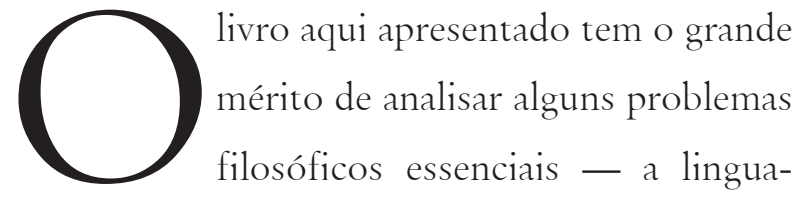
gem, o mito, o tempo, a imagem —, problemas que nos fazem pensar e que deveriam servir como incentivo e encorajamento para uma leitura mais atenta e cuidadosa da obra de Plotino, esse grande filósofo da antiguidade tardia ainda pouco estudado em nosso meio.

Assim, Plotino, escultor de mitos surge no cenário editorial brasileiro como um dos primeiros frutos bem vindos oriundos da recente, mas já importante pesquisa de nossos jovens investigadores sobre esse pensador instigante e complexo, cuja obra, como se sabe, é decisiva não apenas para a compreensão da filosofia medieval, renascentista, e idealista, mas que continua fundamental até mesmo para o melhor entendimento da filosofia francesa contemporânea.

Fernando Rey Puente
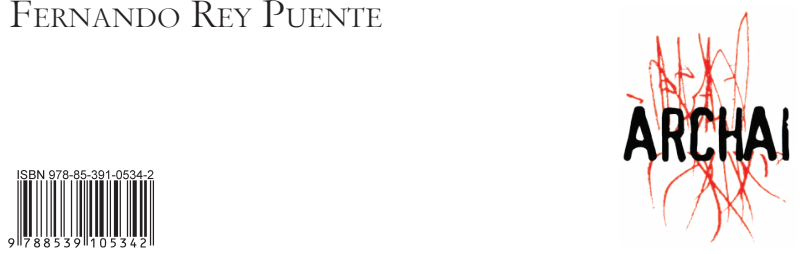